\title{
Schoolverlaters tussen onderwijs en arbeidsmarkt 2010
}

ROA-R-2011/7

Researchcentrum voor Onderwijs en Arbeidsmarkt

Maastricht University

School of Business and Economics

Maastricht, september 20II 


\section{Colofon}

(C) Researchcentrum voor Onderwijs en Arbeidsmarkt (ROA). Niets uit deze uitgave mag op enige manier worden verveelvoudigd zonder voorafgaande schriftelijke toestemming van de directeur van het ROA.

\section{Researchcentrum voor Onderwijs en Arbeidsmarkt}

Maastricht University

School of Business and Economics

\section{Vormgeving}

ROA secretariaat, Maastricht

\section{Verkoop}

Researchcentrum voor Onderwijs en Arbeidsmarkt email: secretary-roa-sbe@maastrichtuniversity.nl website: www.roa.nl

ISBN: 978-90-532I-497-8

september 2OII 


\section{Inhoud}

Voorwoord

1 Kwaliteit van gediplomeerde schoolverlaters

$\begin{array}{llr}1.1 & \text { Inleiding } & 1 \\ 1.2 & \text { Leeswijzer } & 2 \\ 1.3 & \text { Opleiding: Kwalificatie } & 3 \\ 1.4 & \text { Opleiding: Selectiviteit } & 8 \\ 1.5 & \text { Opleiding: Studiebegeleiding en voorlichting } & 12 \\ 1.6 & \text { Vervolgonderwijs: Kwalificerende vervolgtrajecten } & 14 \\ 1.7 & \text { Vervolgonderwijs: Voorbereiding en aansluiting } & 16 \\ 1.8 & \text { Vervolgonderwijs: Succes } & 21 \\ 1.9 & \text { Arbeidsmarkt: Kans op werk } & 23 \\ 1.10 & \text { Arbeidsmarkt: Werkorganisatie en dienstverband } & 29 \\ 1.11 & \text { Arbeidsmarkt: Aansluiting tussen werk en opleiding } & 33 \\ 1.12 & \text { Arbeidsmarkt: Salaris } & 37 \\ 1.13 & \text { Tevredenheid: Werk en opleiding } & 38\end{array}$

2 MBO-diploma in tijden van crisis: de waarde van studie- en beroepskeuzeadviezen 43

$\begin{array}{lll}2.1 & \text { Inleiding } & 43\end{array}$

$\begin{array}{lll}2.2 & \text { Data } & 46\end{array}$

2.3 School-Ex Programma 47

2.4 Succes van studiekeuzeadviezen $\quad 51$

2.5 Succes van beroepskeuzegesprekken $\quad 56$

$\begin{array}{lll}2.6 & \text { Conclusie en evaluatie } & 63\end{array}$

3 Een nadere analyse van redenen voor voortijdig schoolverlaten $\quad 65$

$\begin{array}{lll}3.1 & \text { Inleiding } & 65\end{array}$

3.2 Wat zijn de belangrijkste redenen voor voortijdig schoolverlaten? 66

$\begin{array}{ll}3.3 & \text { In hoeverre zijn er veranderingen in de tijd? }\end{array}$

$\begin{array}{ll}3.4 & \text { Analyse van belangrijkste reden }\end{array}$

$\begin{array}{lll}3.5 & \text { Terugkeer in het onderwijs } & 81\end{array}$

3.6 Spijt achteraf van de keuze om te stoppen $\quad 84$

$\begin{array}{lll}3.7 & \text { Discussie en conclusies } & 85\end{array}$

$\begin{array}{lr}\text { Literatuur } & 87\end{array}$ 
Bijlage 1: Tabel hoofdstuk 1

Bijlage 2: Tabellen hoofdstuk 2

Bijlage 3: Tabellen hoofdstuk 3

Bijlage 4: Kernindicatoren

Statistische Bijlage

Tabellen naar opleidingssector 


\section{Voorwoord}

Wat vinden gediplomeerde schoolverlaters van hun opleiding en wat gaan ze na hun opleiding doen? Hoe is de aansluiting met het vervolgonderwijs? En als ze naar de arbeidsmarkt gaan, hoe snel krijgen ze dan werk? En sluit dat werk dan ook aan op de gevolgde opleiding? Waarom verlaten jongeren het onderwijs voortijdig? Wie van hen vindt de weg terug naar het onderwijs?

Sinds 199I voert het Researchcentrum voor Onderwijs en Arbeidsmarkt (ROA) van Maastricht University in samenwerking met DESAN Research Solutions enkele grootschalige onderzoeken uit onder recente schoolverlaters en pas afgestudeerden waarmee op dit soort vragen een antwoord kan worden gegeven. Het voorliggende rapport Schoolverlaters tussen onderwijs en arbeidsmarkt 2010 gaat in op de transitie van school naar werk of vervolgonderwijs van gediplomeerde schoolverlaters en op de redenen voor het voortijdig verlaten van het onderwijs. De resultaten die worden gepresenteerd zijn gebaseerd op het onderzoek dat eind 2010 over bijna de volle breedte van het Nederlandse onderwijsstelsel is uitgevoerd, en hebben betrekking op de situatie van (voortijdige) schoolverlaters (VMBO, AVO en $\mathrm{MBO}$ ) en afgestudeerden (HBO) ongeveer anderhalf jaar na het voltooien van de opleiding dan wel het voortijdig verlaten van het onderwijs. In totaal zijn ruim 94.000 schoolverlaters en afgestudeerden benaderd. De totale respons bedroeg 30\%. De verzamelde gegevens vormen samen het door het ROA ontwikkelde SchoolverlatersInformatieSysteem (SIS). Dit informatiesysteem is gebaseerd op grootschalige enquêtes die volgens een geïntegreerd model worden uitgevoerd.

Allereerst betreft het de VO-Monitor. Deze enquête is gericht op gediplomeerde schoolverlaters van het algemeen voortgezet onderwijs (HAVO, VWO) en het voorbereidend beroepsonderwijs (VMBO). Daarnaast zijn er de BVE-Monitor, een enquête onder gediplomeerde schoolverlaters van de beroepsopleidende (BOL) en beroepsbegeleidende leerweg (BBL) van het middelbaar beroepsonderwijs (MBO) en de $\mathrm{HBO}-M o n i t o r$, een enquête gericht op afgestudeerden van het hoger beroepsonderwijs (HBO). De HBO-Monitor wordt uitgevoerd onder auspiciën van de HBO-raad. Tot slot betreft het de VSV-Monitor, een enquête onder voortijdige schoolverlaters van het VMBO, het $\mathrm{MBO}$ en het AVO.

De projectleiding van Schoolverlaters tussen onderwijs en arbeidsmarkt 2010 berust bij dr. Christoph Meng. De rapportage is geschreven door dr. Jim Allen, drs. Timo Huijgen, dr. Christoph Meng en drs. Jesper van Thor. De Statistische Bijlage is samengesteld door Paul van der Kolk. Secretariële ondersteuning is verleend door Mariëlle Beenkens en Esther Soudant. Voornoemde personen zijn allen werkzaam bij het ROA. Aan SIS werken verder mee drs. M.C.M.Th. van Alphen, drs. J.M.R. van Dongen en drs. B.M. Kinket (allen werkzaam bij DESAN Research Solutions).

Een speciaal woord van dank gaat uit naar P. Dijkstra, N. Nijdam en I. Dijkema (allen werkzaam bij de Dienst Uitvoering Onderwijs te Groningen) voor de medewerking bij het uitzetten van de steekproeven onder zowel de gediplomeerde als de voortijdige schoolverlaters 
van het $\mathrm{VMBO}$, het $\mathrm{MBO}$ en het $\mathrm{AVO}$. Een speciaal woord van dank wordt verder gericht aan de vertegenwoordigers van de subsidieverstrekkers die zitting hebben in de klankbordgroep: drs. M. Doll (werkzaam bij het Ministerie van Sociale Zaken en Werkgelegenheid), drs. U. Teunis (werkzaam bij het Ministerie van Economische Zaken, Landbouw en Innovatie), S. Dannenburg, J.A. de Hoog, P. van Ooijen, drs. drs. B. Verlaan en drs. M. Warmerdam (allen werkzaam bij het Ministerie van Onderwijs, Cultuur en Wetenschap).

De subsidiemiddelen maken de basisvoorziening mogelijk (dataverzameling, technisch databeheer, methoden- en modellenstudies). Deze basisvoorziening maakt een breed pallet van strategisch onderzoek mogelijk, van proefschriften, wetenschappelijke en beleidsrelevante artikelen tot landelijke beleidsrapportages. Het dankzij de basisvoorziening ontstane databestand geeft daarbij in beginsel de mogelijkheid om de transitie van onderwijs naar vervolgonderwijs/arbeidsmarkt op landelijk niveau in kaart te brengen. Daarnaast biedt de basisvoorziening de startmogelijkheid om op een efficiënte manier uitgebreidere en diepgaandere studies op bijvoorbeeld regionaal, sectoraal of schoolniveau te bewerkstellingen. Regionale overheden of bijvoorbeeld onderwijsoverkoepelende organisaties kunnen dankzij deze basisvoorziening op eenvoudige en kostenefficiënte wijze beleidsrelevante informatie verzamelen en tegen het landelijke beeld afzetten.

Maastricht, september $20 I I$

Prof. dr. T.J. Dohmen

directeur 


\section{Samenvatting}

Het Researchcentrum voor Onderwijs en Arbeidsmarkt (ROA) verricht jaarlijks onderzoek onder schoolverlaters naar de overgang van school naar vervolgopleiding of arbeidsmarkt. Het voorliggende rapport presenteert de resultaten van de meting die eind 2010 is gehouden onder de gediplomeerde schoolverlaters en de voortijdige schoolverlaters van het schooljaar 2008-2009, dat wil zeggen ongeveer anderhalf jaar na het voltooien of verlaten van de opleiding. De resultaten hebben betrekking op nagenoeg de volle breedte van het onderwijs: VMBO, MBO-BOL, MBO-BBL, HAVO, VWO, HBO. ${ }^{\mathrm{I}}$ In totaal zijn ruim 84.000 gediplomeerde schoolverlaters en afgestudeerden en ruim Io.000 voortijdige schoolverlaters benaderd. De totale respons bedroeg 30\%. Het rapport kent een drietal hoofdstukken:

\section{Kwaliteit van gediplomeerde schoolverlaters}

Hoofdstuk I gaat in op de vraag hoe het de gediplomeerden en afgestudeerden is vergaan nadat ze de opleiding in 2009 hebben verlaten. In hoofdlijnen omvat het hoofdstuk achtereenvolgens een discussie van a) het oordeel van de gediplomeerden over de gevolgde opleiding, b) de voorbereiding op en het succes in de vervolgopleiding, c) de voorbereiding op en het succes op de arbeidsmarkt en d) de algemene tevredenheid achteraf.

Tabel S.1

Enkele kernindicatoren

\begin{tabular}{|c|c|c|c|c|c|}
\hline & $\begin{array}{r}\text { Verder leren } \\
\%\end{array}$ & $\begin{array}{r}\text { Werkloosheid } \\
\%\end{array}$ & $\begin{array}{r}\text { Eigen niveau } \\
\%\end{array}$ & $\begin{array}{r}\text { Eigen domein } \\
\%\end{array}$ & $\begin{array}{r}\text { Zelfde opleiding } \\
\%\end{array}$ \\
\hline AVO & 87 & 15 & $X$ & $x$ & 9 \\
\hline VMBO & 96 & 8 & 92 & 65 & 84 \\
\hline BOL 1 & 67 & 25 & 79 & 77 & 72 \\
\hline BOL 2 & 58 & 14 & 74 & 59 & 75 \\
\hline BOL 3 & 48 & 5 & 77 & 78 & 79 \\
\hline BOL 4 & 57 & 6 & 87 & 76 & 79 \\
\hline BBL 1 & 29 & 7 & 44 & 51 & 75 \\
\hline BBL 2 & 34 & 5 & 69 & 64 & 81 \\
\hline BBL 3 & 25 & 2 & 68 & 79 & 85 \\
\hline BBL 4 & 24 & 2 & 84 & 83 & 83 \\
\hline HBO & 36 & 6 & 80 & 79 & 79 \\
\hline Totaal & 66 & 6 & 77 & 73 & 81 \\
\hline
\end{tabular}

$\mathrm{X}=$ Vraag niet opgenomen; Verder leren $=\%$ respondenten dat een vervolgopleiding is gaan volgen; Werkloosheid $=$ werkzoekenden als \% van de schoolverlaters die zich op de arbeidsmarkt aanbieden; Eigen niveau $=\%$ van de werkende schoolverlaters dat aangeeft dat de werkgever voor deze functie minimaal een diploma van het gevolgde onderwijsniveau vereist; Eigen domein = \% van de werkende schoolverlaters dat aangeeft dat de werkgever voor deze functie een diploma van de gevolgde opleidingsrichting of een verwante opleidingsrichting vereist; Zelfde opleiding $=\%$ van de schoolverlaters dat, achteraf bezien, opnieuw dezelfde opleiding zou kiezen.

I. In 2010 heeft de VSNU geen meting onder universitair afgestudeerden gehouden. Er kunnen daardoor geen resultaten voor deze groep gepresenteerd worden. De eerstvolgende meting onder de afgestudeerden van het WO vindt plaats in het najaar van $201 \mathrm{I}$. 
De belangrijkste conclusies zijn:

\section{a. Oordelen over gevolgde opleiding}

- Voorbereiding op arbeidsmarkt kritisch beoordeeld: Slechts $42 \%$ van de gediplomeerde uitstroom vindt dat de gevolgde opleiding een goede basis biedt om te starten op de arbeidsmarkt. Alleen bij de gediplomeerden van het MBO-BBL niveau 3 (60\%) en niveau $4(63 \%)$ en het $\mathrm{HBO}(5 \mathrm{I} \%)$ is het een (lichte) meerderheid.

- Relatief goede voorbereiding op verder leren: $65 \%$ van de gediplomeerde uitstroom vindt dat de gevolgde opleiding een goede basis biedt om kennis en vaardigheden verder te ontwikkelen.

- Onderwijs mag pittiger: De gediplomeerden zijn kritisch wat de selectiviteit tijdens de opleiding betreft. Slechts een kleine groep vindt dat de docenten streng waren $(2 \mathrm{I} \%)$, de examens en opdrachten pittig waren $(27 \%)$ en de opleiding uitdagend was $(34 \%)$.

- Oordelen stabiel over tijd: De oordelen van de gediplomeerden wat betreft de voorbereiding en de selectiviteit van het onderwijs zijn in vergelijking met de afgelopen jaren nauwelijks veranderd.

b. Vervolgonderwijs (gediplomeerden van het $M B O$, AVO en VMBO)

- Goede voorbereiding: De gediplomeerden zijn in de regel tevreden over de voorlichting en studiebegeleiding.

- Goede aansluiting: De gediplomeerden ervaren in de regel een goede aansluiting met de gekozen vervolgopleiding. De aansluiting lijkt daarbij het meest moeizaam voor het $\mathrm{HBO}$.

- Veel studiewisselaars, weinig netto uitval onder gediplomeerden van het AVO: $15 \%$ van de gediplomeerden van het AVO stopt alweer in het eerste jaar van het vervolgonderwijs. Slechts 3\%-punt daarvan stapt definitief uit het onderwijs.

\section{c. Arbeidsmarkt}

- Arbeidsmarkt stabiliseert zich: 5,6\% (meting 2009: 6,4\%) van de gediplomeerden van het $\mathrm{MBO}$ en 6,0\% (meting 2009: 6,0\%) van de afgestudeerden van het $\mathrm{HBO}$ is op het moment van de enquête werkloos. Onder de gediplomeerden van het $\mathrm{MBO}$ niveau I is de werkloosheid (aanzienlijk) hoger, maar deze groep gediplomeerden profiteerde het meest van het economische herstel in de tweede helft van 20 Io.

- Goede aansluiting opleiding-werk: $73 \%$ van de werkende gediplomeerden van het $\mathrm{MBO}$ en het $\mathrm{HBO}$ is van mening dat de functie goed aansluit bij de opleiding qua richting en $77 \%$ vindt dat de opleiding goed aansluit bij de opleiding qua niveau.

\section{d. Tevredenheid achteraf}

- Grote meerderheid zou zelfde keuze maken: $8 \mathrm{I} \%$ zou achteraf bezien opnieuw voor dezelfde opleiding kiezen.

\section{MBO-diploma in tijden van crisis: de waarde van studie- en beroepskeuzeadviezen}

In dit hoofdstuk staan we nader stil bij de problemen die de gediplomeerden van het $\mathrm{MBO}$ in de twee crisisjaren (2009-20Io) tegenkwamen. We doen dit door te kijken naar zowel 
kwantitatieve als kwalitatieve effecten van persoonlijke studie- en beroepskeuzeadviezen. We stellen ondermeer de vraag of scholen in staat zijn om jongeren te beïnvloeden bij hun keuze om zich aan te bieden op de arbeidsmarkt of een vervolg te geven aan hun onderwijscarrière. We vragen of studiekeuzeadviezen tot een hoger rendement in het vervolgonderwijs kunnen leiden en of beroepskeuzeadviezen in tijden van economische malaise de overgang van onderwijs naar arbeidsmarkt kunnen versoepelen. Het hoofdstuk heeft daarmee een tweeledig doel. Aan de ene kant biedt het een algemene discussie van de mogelijke effecten die studieen beroepskeuzeadviezen in tijden van economische crisis teweeg kunnen brengen. Aan de andere kant biedt het hoofdstuk een bijdrage aan een evaluatie van het School-Ex Programma.

De belangrijkste conclusies zijn:

\section{a. Kwantitatieve effecten}

- Druk op arbeidsmarkt verlicht: Persoonlijke studiekeuzeadviezen vergroten de kans dat jongeren na het behalen van het $\mathrm{MBO}$-diploma hun onderwijscarrière voortzetten, wat de druk op de arbeidsmarkt in tijden van economische crisis verlicht.

- Kans op werk neemt toe: Jongeren die een beroepskeuzeadvies hebben ontvangen kennen een significant kortere intredewerkloosheid. Deze kortere intredewerkloosheid heeft ook een positief effect op de kans op werk anderhalf jaar later, wat de baten van beroepskeuzegesprekken verder onderbouwt.

\section{b. Kwalitatieve effecten}

- Betere aansluiting met vervolgonderwijs: Dankzij persoonlijke studiekeuzeadviezen komen jongeren beter op een plek terecht die aansluit bij hun capaciteiten. Dit verlaagt de kans dat ze al op korte termijn met de vervolgopleiding stoppen.

- Betere aansluiting met werk: Jongeren die een persoonlijk beroepskeuzeadvies hebben ontvangen kennen in de regel een betere aansluiting tussen werk en gevolgde opleiding en daardoor een betere benutting van hun capaciteiten en betere carrièreperspectieven.

\section{c. Algemeen effect}

- Groot belang in goede en slechte tijden: Door MBO-scholen aangeboden studie- en/ of beroepskeuzeadviezen zijn van groot belang voor zowel de individuele gediplomeerde alsook voor de Nederlandse kenniseconomie in zijn geheel. Dit geldt zeker in economisch slechte tijden, maar ook in economisch goede tijden mogen deze effecten niet onderschat worden.

\section{Een nadere analyse van redenen voor voortijdig schoolverlaten}

Hoofdstuk 3 gaat in op vragen zoals "waarom verlaten jongeren het onderwijs voortijdig?", "zijn er verschillen in de genoemde redenen tussen bijvoorbeeld de grote steden en de rest van het land" en "welke redenen kennen een onderliggend verband?". Daarnaast gaan we na in hoeverre bepaalde redenen 'slechts' een voorbode zijn voor een tijdelijk en kort vertrek uit het onderwijs en welke redenen een zodanige barrière vormen dat jongeren ook na 2-4 jaren de weg terug naar het onderwijs niet hebben gevonden. De resultaten in het voorliggende hoofdstuk zijn afkomstig van steekproeven onder voortijdige schoolverlaters die een oplei- 
ding in het VMBO, het MBO, het HAVO of het VWO in de periode 2005 tot en met 2009 zonder diploma hebben verlaten (VSV zonder diploma).

De belangrijkste conclusies zijn:

\section{a. Redenen van voortijdig schoolverlaten}

- Redenen blijven stabiel over tijd: Een verkeerde studiekeuze, de (geestelijke) gezondheid en de aantrekkingskracht van de arbeidsmarkt zijn de drie belangrijkste oorzaken voor voortijdig schoolverlaten. Deze redenen vormen in de afgelopen 5 jaren een stabiele 'top 3'.

- Economische crisis heeft weinig invloed op redenen: De economische crisis van 2009 heeft weinig effect op de redenen voor voortijdig schoolverlaten.

- Geen grote steden effect: Er is weinig verschil tussen de grote steden en de rest van Nederland, niet alleen in de verdeling van de belangrijkste redenen voor uitval, maar ook in de trends in deze redenen in de tijd.

- Push en pull effecten werken samen: Relatief veel voortijdige schoolverlaters die vanwege arbeidsmarktgerelateerde redenen zijn gestopt (pull), vermelden ook dat de opleiding niet aan de verwachting voldeed (push). Uitval vanwege arbeidsmarktgerelateerde redenen kan dan ook worden bestreden met betere voorlichting (ex-ante) en ondersteuning (ex-post).

\section{b. Terugkeer in het onderwijs}

- Voortijdig maar niet voor altijd: Bijna $40 \%$ van de jongeren die het onderwijs in het schooljaar 2007-2008 voortijdig heeft verlaten is in het voorjaar van $201 \mathrm{I}$ weer actief in het onderwijs of heeft alweer een diploma in het onderwijs behaald.

- Redenen voor uitval beïnvloeden kans op terugkeer: Een succesvolle terugkeer is het minst waarschijnlijk wanneer de belangrijkste reden voor vertrek de aantrekkingskracht van de arbeidsmarkt is. Jongeren die vanwege zorgverplichting, persoonlijke problemen, problemen op school of (geestelijke) gezondheidsproblemen zijn gestopt maken ook relatief zelden een succesvolle terugkeer.

\section{Website "Kerncijfers Schoolverlatersonderzoeken" \\ www.roa.unimaas.nl/kerncijfers.htm}

De website biedt de mogelijkheid om alle cijfers afkomstig van de schoolverlatersonderzoeken van het Researchcentrum voor Onderwijs en Arbeidsmarkt (ROA) op een eenvoudige manier op te vragen. Via een menu kunnen de kerncijfers geraadpleegd worden via twee hoofdgroepen 'naar onderwijs' en 'naar onderwerp'. De hoofdgroep "Naar Onderwijs" laat alle kerncijfers zien naar een in het menu te selecteren onderwijsniveau, -sector of opleiding. De hoofdgroep "Naar Onderwerp" laat één in het menu te selecteren kerncijfer zien naar alle onderwijsniveaus, -sectoren of opleidingen. De website biedt naast een overzicht van de meest actuele resultaten ook de cijfers afkomstig van eerdere metingen onder de gediplomeerde schoolverlaters en de afgestudeerden van het Nederlandse onderwijs. 


\section{Kwaliteit van gediplomeerde schoolverlaters}

\subsection{Inleiding}

In dit hoofdstuk wordt ingegaan op de vraag hoe het de gediplomeerde schoolverlaters is vergaan nadat ze de opleiding in 2009 hebben verlaten. ${ }^{2}$ Dit gebeurt aan de hand van enkele indicatoren die samen iets zeggen over het succes van de transitie naar vervolgonderwijs of arbeidsmarkt. Deze indicatoren geven een beeld van de kwaliteit van de output van het onderwijs, zoals we dat kunnen vaststellen bij schoolverlaters.

De kwaliteit van het onderwijs wordt doorgaans vanuit twee invalshoeken beoordeeld: het onderwijs moet doeltreffend (effectief) zijn en het moet doelmatig (efficiënt) zijn. De doeltreffendheid is ontleend aan de functies die het onderwijs moet vervullen: kwalificatie, selectie en allocatie (Peschar \& Wesseling, 200I). De doelmatigheid wordt vastgesteld op basis van het extern rendement: dit betreft de opbrengsten op de arbeidsmarkt of in het vervolgonderwijs voor de schoolverlaters.

Voor elk van de onderscheiden aspecten - kwalificatie, selectie, allocatie en extern rendement - worden in dit hoofdstuk meerdere indicatoren besproken. Daarnaast bespreken we verdere aspecten zoals begeleiding tijdens de opleiding, voorlichting over studie- en beroepsmogelijkheden en kijken we naar de algemene tevredenheid van de schoolverlaters met de gevolgde opleiding. Dit laatste aspect kan beschouwd worden als een indicator voor de mate waarin verwachtingen van studenten overeenkomen met hun feitelijke ervaringen.

\section{Kwalificatie}

Voor een goede doorstroom naar vervolgonderwijs of arbeidsmarkt is het noodzakelijk dat de schoolverlater in voldoende mate beschikt over de vereiste competenties. De centrale vraag is dan ook of het onderwijs er in is geslaagd om schoolverlaters met deze competenties toe te rusten. Hierbij gaat het niet alleen om de startbekwaamheid van de schoolverlaters maar ook om de mate waarin de opleiding een voldoende basis biedt voor de verdere ontwikkeling van 'novice' tot 'expert' (het ontwikkelpotentieel) en voor de mate waarin de opleiding heeft bijgedragen aan de algehele 'employability' van de schoolverlater.

2. Gediplomeerde schoolverlaters worden in dit hoofdstuk gedefinieerd als schoolverlaters die in het schooljaar 2008-2009 hun diploma hebben behaald. Hierbij speelt het geen rol of dit diploma het predicaat "startkwalificatie" in de zin van een diploma op minimaal MBO niveau 2 heeft of niet. 


\section{Selectie}

De betrouwbaarheid waarmee het onderwijs haar studenten beoordeelt op de aanwezige competenties en op grond hiervan een eindniveau certificeert is van groot belang. De legitimering van het diploma is namelijk voor een groot deel gelegen in de betrouwbaarheid hiervan. Zowel onderwijsinstellingen zelf als bijvoorbeeld werkgevers zullen er op moeten kunnen vertrouwen dat een schoolverlater met een bepaald eindcertificaat ook daadwerkelijk beschikt over de competenties die bij het betreffende diploma horen. Over deze betrouwbaarheid zijn echter maar weinig gegevens beschikbaar. In dit hoofdstuk maken we hiervoor gebruik van de oordelen van de schoolverlaters over de selectiviteit van hun opleiding.

\section{Allocatie}

De allocatie richt zich op de vraag hoe de aansluiting tussen de gevolgde opleiding en het vervolgonderwijs c.q. de arbeidsmarkt verloopt. Met betrekking tot deze aansluiting kan dan bijvoorbeeld gekeken worden naar de vraag in hoeverre men werk gevonden heeft dat wat niveau en richting betreft goed aansluit bij de gevolgde opleiding.

\section{Extern rendement}

Het extern rendement betreft de opbrengsten van het gevolgde onderwijs. Kijken we naar de doorstroom naar de arbeidsmarkt dan betreft dit vragen zoals 'Wat zijn de baankansen', 'Wat is de werkzekerheid', 'Wat verdient men' of 'Wat zijn de carrièreperspectieven'. Als we naar de doorstroom naar de vervolgopleiding kijken is de centrale vraag natuurlijk 'Hoe succesvol zijn de jongeren in hun vervolgopleiding'.

\section{Tevredenheid achteraf}

Vooral voor onderwijsinstellingen is het van belang om te weten in welke mate de gediplomeerde uitstroom achteraf weer voor dezelfde opleiding en dezelfde school zou kiezen. Met andere woorden, zijn de schoolverlaters tevreden over de gekozen opleiding en de gekozen school?

\subsection{Leeswijzer}

In de navolgende paragrafen staan we uitgebreider stil bij de bovengenoemde aspecten van het onderwijs. De hoofdbron van de gepresenteerde cijfers zijn daarbij de schoolverlatersen afgestudeerdenonderzoeken die in het najaar van 2010 hebben plaatsgevonden. Deze betreffen jongeren die in het school-/studiejaar 2008-2009 een diploma in het Nederlandse voltijd onderwijs hebben behaald (VMBO, HAVO, VWO, MBO en $\mathrm{HBO}^{3}$ ). Tabel I.I laat per onderwijstype het aantal benaderde schoolverlaters/afgestudeerden, het responspercentage, het aantal respondenten en het gewogen aantal zien. Het gewogen aantal ontstaat door het aantal respondenten a) te wegen en b) op te hogen. De weging is gebaseerd op respons-

3. In 2010 heeft geen onderzoek onder de afgestudeerden van het WO plaatsgevonden. De eerstvolgende meting onder deze groep afgestudeerden vindt in het najaar van 201 plaats (afgestudeerden van het studiejaar 2009-2010). 
verschillen tussen onder andere opleiding, opleidingsniveau, regio en geslacht. De ophoging is gebaseerd op het aantal afgestudeerden van de opleiding in het desbetreffende studiejaar. Een gedetailleerder overzicht (op opleidingssector) over de aantallen en de respons staat in tabel I van de Statistische Bijlage.

Tabel 1.1

Schoolverlatersonderzoeken 2010

\begin{tabular}{lrrrr}
\hline Onderwijstype & Benaderde aantallen & Responspercentage & Aantal respondenten & Gewogen aantal \\
\hline HAVO & 1.922 & 35 & 667 & 40.713 \\
\hline VWO & 1.681 & 41 & 691 & 34.093 \\
\hline VMBO & 10.519 & 28 & 2.969 & 85.005 \\
\hline MBO-BOL & 19.611 & 24 & 4.603 & 82.328 \\
MBO-BBL & 9.472 & 20 & 1.871 & 56.488 \\
\hline HBO & 40.882 & 38 & 14.861 & 49.506 \\
& & & & 348.133 \\
\hline Totaal & 84.307 & 31 & 25.662 &
\end{tabular}

Tenzij anders vermeld worden in dit hoofdstuk altijd resultaten op basis van de gewogen aantallen gepresenteerd. De cijfers waar dit hoofdstuk op is gebaseerd zijn in meer gedetailleerde vorm terug te vinden in de Statistische Bijlage behorende bij dit rapport.

\subsection{Opleiding: Kwalificatie}

Voor een succesvolle start op de arbeidsmarkt of het met succes volgen van een vervolgstudie is het een eerste vereiste dat de schoolverlater beschikt over de benodigde competenties. In hoeverre het onderwijs er in is geslaagd de schoolverlater de benodigde competenties bij te brengen is het aandachtspunt van het aspect kwalificatie. Voor schoolverlaters die naar de arbeidsmarkt doorstromen, is hierbij niet alleen relevant of de opleiding hen startbekwaam heeft gemaakt maar ook of de opleiding een goede basis biedt voor de verdere ontwikkeling en de algehele employability van de schoolverlaters.

Om hier inzicht in te krijgen is aan de schoolverlaters gevraagd de afgeronde opleiding te beoordelen op een viertal aspecten: (I) de breedte van de opleiding (te smal $<->$ te breed), (2) de diepgang van de opleiding (te weinig diepgang $<->$ te veel diepgang), (3) de mate waarin de opleiding een goede basis biedt om te starten op de arbeidsmarkt en (4) de mate waarin de opleiding een goede basis biedt om kennis en vaardigheden verder te ontwikkelen. De eerste twee aspecten zeggen iets over de evenwichtigheid van het studieprogramma, terwijl de laatste twee aspecten iets zeggen over de voorbereiding op de arbeidsloopbaan.

\section{Evenwichtigheid van de opleiding: breedte en diepgang}

Een eerste blik op tabel I.2 laat zien dat de gediplomeerde schoolverlaters in het algemeen tevreden zijn over de evenwichtigheid van de opleiding. Wat de breedte betreft vond $83 \%$ deze goed in evenwicht en slechts $I$ \% $(6 \%)$ vond de opleiding te breed (te smal). Ook wat de diepgang van de opleiding betreft is de overgrote meerderheid $(85 \%)$ tevreden en vond 'slechts' $15 \%$ dat de opleiding te weinig diepgang had. De groep van $85 \%$ die tevreden is over 
de diepgang van de opleiding bestaat overigens voor 5\%-punten uit personen die vinden dat de opleiding te veel diepgang had. Alhoewel te veel diepgang minder bezwaarlijk is dan te weinig diepgang kan ook dit een indicatie zijn dat een opleiding niet goed aansluit bij de arbeidsmarkt of het vervolgonderwijs.

Opvallend is dat op beide indicatoren de opleidingen van het $\mathrm{HBO}$ relatief gezien minder goed beoordeeld worden. Zo vindt $24 \%$ van de afgestudeerden van het $\mathrm{HBO}$ de opleiding te breed en vindt $2 \mathrm{I} \%$ dat de opleiding te weinig diepgang bezit. Qua tevredenheid met de breedte (zie voor de onderliggende cijfers tabel 4 van de Statistische Bijlage) kunnen de $\mathrm{HBO}$-sectoren verder in een drietal groepen onderscheiden worden:4 (I) de HBO sector onderwijs waar minder dan IO\% van mening is dat de opleiding te breed opgezet was, (2) de HBO sectoren Gezondheidszorg en Techniek waar zo'n 20\% deze mening heeft en (3) de HBO sectoren Landbouw, Economie en Gedrag \& Maatschappij waar zo'n 30\% vindt dat de opleiding te breed was.

MBO-opleidingen scoren relatief gezien goed wat de breedte van de opleiding betreft. Op alle niveaus vindt ten minste $80 \%$ van de gediplomeerden van het $\mathrm{MBO}$ dat de opleiding op dit punt in evenwicht was. De gediplomeerden van het MBO-BBL zijn zelfs nog iets meer tevreden. Echter het verschil met het MBO-BOL is klein en het lijkt er dan ook niet op dat de tevredenheid met betrekking tot de breedte rechtstreeks met de leerweg samenhangt. Op alle MBO-niveaus zijn verder verschillen tussen de onderliggende opleidingssectoren te vinden (zie tabel 4 in de Statistische Bijlage). Deze zijn echter relatief gezien klein. Ook de afgestudeerden van het VMBO en het AVO zijn in vergelijkbare mate tevreden. Dit geldt ook voor de individuele leerwegen of sectoren in het $\mathrm{VMBO}$. Zo vindt $8 \%$ van de gediplomeerden van het VMBO-TL dat de opleiding te breed was en is dat bij de gediplomeerden van het VMBO-KB Iо\%.

\section{Tabel 1.2}

Breedte en diepgang van opleiding (\%)

\begin{tabular}{|lrr|r|}
\hline HAV0 & Te smal & Te breed & Te weinig diepgang \\
\hline VW0 & 3 & 6 & 13 \\
\hline VMB0 & 3 & 8 & 12 \\
\hline MBO-BOL 1 & 8 & 9 & 11 \\
\hline MBO-BOL 2 & & & 11 \\
\hline MBO-BOL 3 & 9 & 10 & 13 \\
\hline MBO-BOL 4 & 8 & 10 & 19 \\
\hline MBO-BBL 1 & 7 & 10 & 23 \\
\hline MBO-BBL 2 & 9 & 11 & 6 \\
\hline MBO-BBL 3 & & & 9 \\
\hline MBO-BBL 4 & 3 & 8 & 10 \\
\hline HBO & 9 & 9 & 24 \\
\hline Totaal & 5 & 8 & 21 \\
\hline Zie ook Tabel 4 in de Statistische Bijlage & 7 & 24 & 15 \\
\hline
\end{tabular}

4. Deze vragen zijn niet aan de afgestudeerden van de $\mathrm{HBO}$ sector Taal en Cultuur gevraagd. 
Zijn het wat de breedte betreft de opleidingen in het HBO die door de afgestudeerden nogal kritisch bekeken worden, wat de diepgang van de opleiding betreft scoren de hoogste MBO-opleidingen vergelijkbaar mager: $23 \%$ van de gediplomeerden van het $\mathrm{MBO}-\mathrm{BOL}$ niveau 4 vindt dat de opleiding te weinig diepgang had en onder de gediplomeerden van het $\mathrm{MBO}-\mathrm{BBL}$ niveau 4 is het $24 \%$. Kijken we naar de onderliggende sectoren dan zien we verder dat de opleidingen in de sector Landbouw in het MBO-BOL niveau 4 (30\%), in de sector Gezondheidszorg in het MBO-BBL niveau 4 (33\%) en in de sector Gedrag en Maatschappij in het MBO-BBL niveau 4 (30\%) volgens de gediplomeerde schoolverlaters de minste diepgang kennen.

In tegenstelling tot het oordeel over breedte dienen we bij het oordeel over de diepgang van de opleiding echter met een bepaald selectie-effect rekening te houden. Onder de gediplomeerden van de hogere $\mathrm{MBO}$-niveaus (en dat geldt zeker ook voor de afgestudeerden van het $\mathrm{HBO}$ ) vinden we een groep jongeren die toegang had tot een hoger opleidingsniveau maar hier niet voor gekozen heeft. Zo vinden we onder de gediplomeerden van $\mathrm{MBO}$ niveau 4 jongeren die ook door hadden kunnen stromen naar een HAVO of zelfs VWO opleiding. Vergelijkbaar vinden we onder de afgestudeerden van het $\mathrm{HBO}$ jongeren die op basis van hun vooropleiding (VWO) ook toegang tot het WO hadden. Een nadere analyse laat dan ook zien dat de afgestudeerden van het HBO die voorafgaand een VWO diploma hebben behaald de opleiding qua diepgang minder gunstig beoordelen dan de afgestudeerden van het $\mathrm{HBO}$ die voorafgaand een HAVO diploma hebben behaald.

Breedte en diepgang van een opleiding staan niet per definitie los van elkaar. In figuur I.I zetten we daarom de twee indicatoren (te breed versus te weinig diepgang) tegen elkaar af. Op de horizontale as staat op sectorniveau (bijvoorbeeld HBO landbouw of MBO-BOL niveau 4 economie) het percentage gediplomeerden dat de opleiding te breed vond. Op de verticale as staat het percentage dat vond dat de opleiding te weinig diepgang had. De opwaartse trendlijn laat zien dat er inderdaad een positieve relatie tussen deze twee indicatoren bestaat. Echter, deze is verre van perfect. Met andere woorden, er zijn voldoende opleidingen waarvan de respondenten vinden dat de opleidding qua breedte aan hun verwachtingen voldeed maar dit niet voor de diepgang geldt en vice versa.

\section{Voorbereiding op arbeidsloopbaan: startbekwaamheid en ontwikkelpotentieel}

Met uitzondering van de opleidingen in het AVO dienen de opleidingen die we hier onderscheiden zowel een goede basis te bieden om te starten op de arbeidsmarkt als een goede basis te vormen voor het verder ontwikkelen van kennis en vaardigheden. Dit lijkt op het eerste gezicht niet van toepassing op het VMBO. Echter, aangezien een aanzienlijk deel van de gediplomeerden van het $\mathrm{VMBO}$ (zie ook paragraaf I.6) hun onderwijscarrière in de beroepsbegeleidende leerweg (BBL) van het $\mathrm{MBO}$ voortzet, dient ook het $\mathrm{VMBO}$ een goede basis om te starten op de arbeidsmarkt te bieden. Immers, leerlingen in het MBO-BBL zijn in de regel 4 dagen per week werkzaam en I dag per week op school. 


\section{Figuur 1.1}

Te breed versus te weinig diepgang (\%)

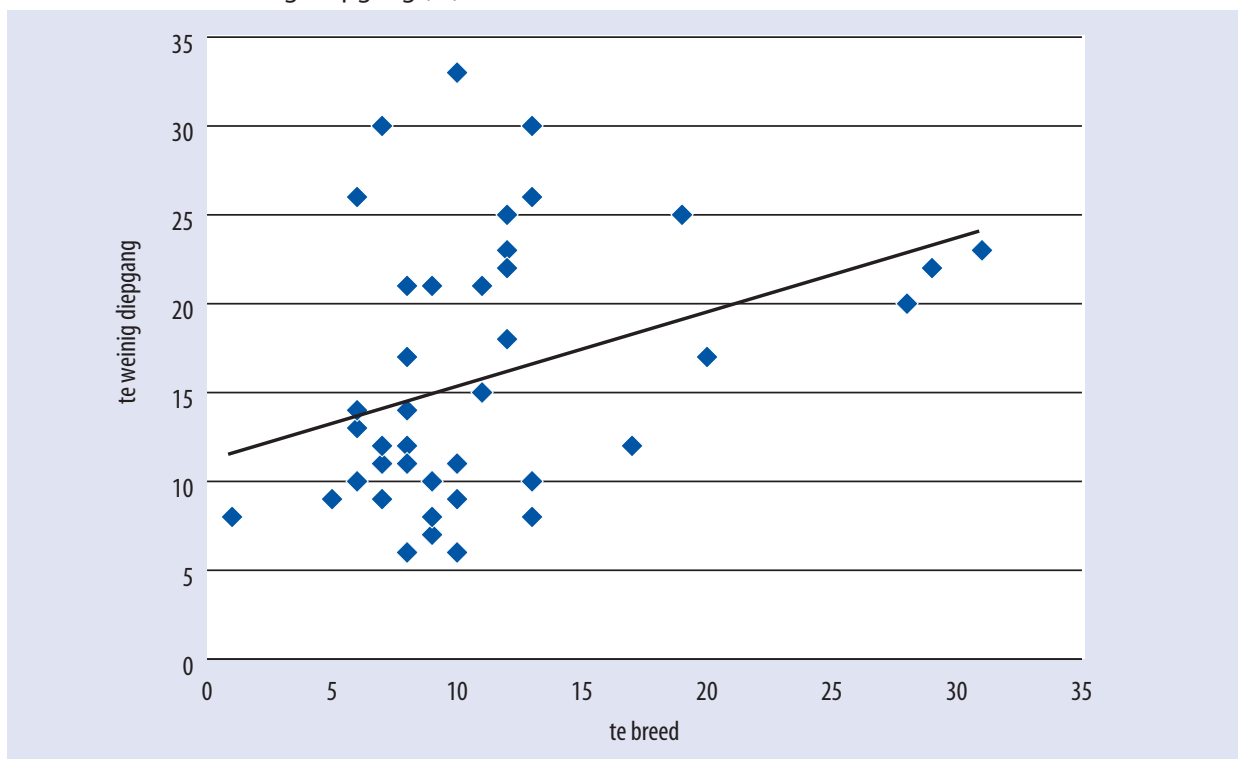

Tabel 1.3

Gediplomeerden dat vindt dat de opleiding een goede basis biedt om te starten op de arbeidsmarkt/om kennis en vaardigheden verder te ontwikkelen (\%)

$\begin{array}{lrrrrrrrrrrr} & \text { VMBO } & \text { BOL 1 } & \text { BBL 1 } & \text { BOL 2 } & \text { BBL 2 } & \text { BOL 3 } & \text { BBL 3 } & \text { BOL 4 } & \text { BBL 4 } & \text { HBO } & \text { Totaal } \\ \text { Starten } & 29 & 35 & 34 & 43 & 48 & 49 & 60 & 42 & 63 & 51 & 42 \\ \text { Verder ontwikkelen } & 58 & 58 & 64 & 59 & 61 & 61 & 67 & 56 & 68 & 65 & 61\end{array}$

Zie ook Tabel 5 in de Statistische Bijlage

De gediplomeerden zijn nogal kritisch wat de basis om te starten op de arbeidsmarkt betreft: slechts $42 \%$ vindt dat de opleiding een goede basis heeft geboden. Uit tabel I.3 blijkt duidelijk dat het VMBO en de MBO niveau I opleidingen geen startkwalificaties zijn. Deze onderwijsniveaus worden het minst positief beoordeeld als het gaat om de opleiding als voorbereiding op de arbeidsmarkt. Echter, ook onder de gediplomeerden van het $\mathrm{MBO}$ als geheel is het geen meerderheid (47\%) en onder de afgestudeerden van het $\mathrm{HBO}$ is het met $5 \mathrm{I} \%$ de kleinst mogelijke meerderheid die wat deze indicator betreft de opleiding positief beoordeelt. In het HBO scoren daarbij de sectoren Onderwijs (62\%), Techniek (60\%) en Gezondheidszorg $(63 \%)$ relatief hoog.

In het $\mathrm{MBO}$ zien we dat opleidingen in de beroepsbegeleidende leerweg (BBL) in de regel beter beoordeeld worden dan de opleidingen in de beroepsopleidende leerweg (BOL). Onder de afgestudeerden van het MBO-BBL niveau 3 (60\% oordeelt positief) en het MBO-BBL niveau $4(63 \%)$ is het een duidelijke meerderheid die positief oordeelt. Vanwege het duale karakter van deze onderwijsvorm liggen deze percentages in de lijn der verwachtingen. Naast de gevolgde leerweg speelt in het $\mathrm{MBO}$ ook de onderwijssector een belangrijke rol (zie figuur I.2): De opleidingen in de sectoren Gezondheidszorg en Gedrag \& Maatschappij worden het meest positief beoordeeld. Dit geldt in de regel ook op de afzonderlijke niveaus (zie tabel 5 
in de Statistische Bijlage). In beide leerwegen (BOL en BBL) volgt de sector Techniek op een derde plaats. De MBO sectoren Landbouw en Economie doen het wat dit aspect betreft het minst goed.

\section{Figuur 1.2}

Basis om te starten op de arbeidsmarkt naar leerweg en sector in het MBO (\%)

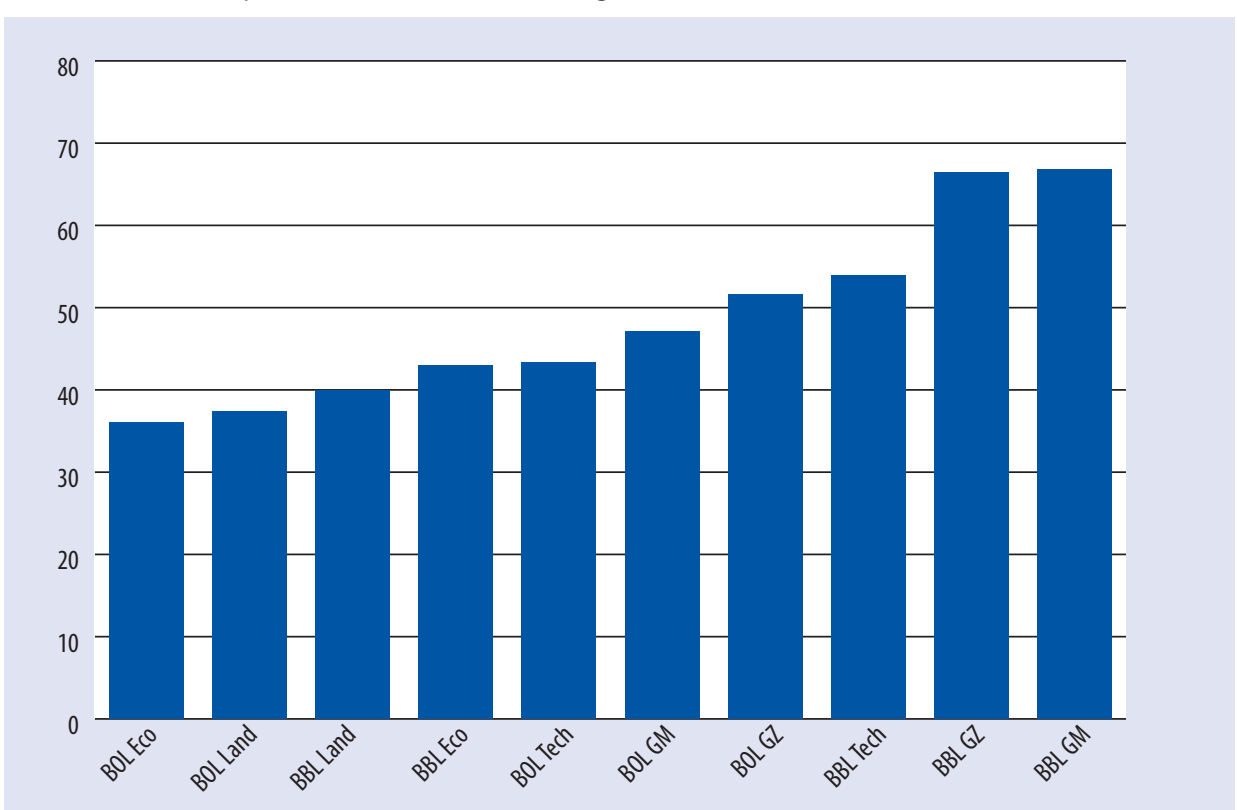

Eco = Economie; Land = Landbouw; Tech = Techniek; GM = Gedrag \& Maatschappij; GZ = Gezondheidszorg

Binnen de sector Economie zijn het verder de BOL-opleidingen op niveau 4 die het meest kritisch beoordeeld worden: slechts een op drie gediplomeerden van deze sector oordeelt positief over de basis om te starten op de arbeidsmarkt. Verontrustend is daarbij dat een jaar eerder (meting 2009) nog 39\% van de gediplomeerde economen (BOL niveau 4) en in meting 2008 nog bijna één op de twee $(46 \%)$ positief oordeelde. Het is natuurlijk nog te vroeg om vast te stellen of dat een algemeen dalende trend bij deze opleidingen is of dat de economische crisis, en de verminderde kans om succesvol op de arbeidsmarkt te starten, hier van invloed is. Tegen het laatste argument spreekt echter het volgende: (a) we zien geen vergelijkbare dalende trend bij de economische opleidingen op MBO-BOL niveau 3 of de zusteropleidingen op MBO-BBL niveau 4 en (b) de werkloosheid onder deze groep gediplomeerden is tussen meting 2009 en meting 2010 niet verder gestegen (zie paragraaf I.9). Het is echter wel zo dat men meer moeite heeft gehad met het vinden van passend werk dan een jaar geleden hetgeen wellicht geleid heeft tot een minder positief oordeel.

Opleidingen in onderwijssectoren die een goede basis bieden om te starten op de arbeidsmarkt worden door de gediplomeerden ook vaker positief beoordeeld wat de basis betreft om kennis en vaardigheden verder te ontwikkelen (zie figuur I.3). 


\section{Figuur 1.3}

Starten op arbeidsmarkt versus verder ontwikkelen kennis en vaardigheden (\%)

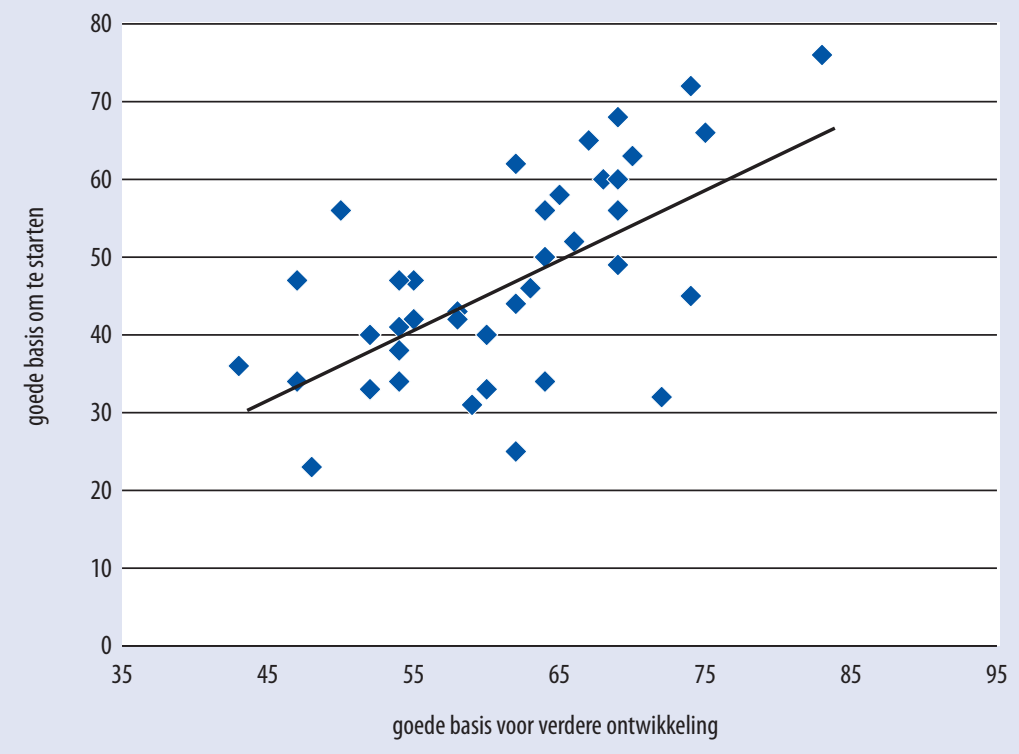

De gediplomeerden zijn duidelijk positiever over de basis om kennis en vaardigheden verder te ontwikkelen: $61 \%$ vindt dat de opleiding hier een goede basis voor heeft geboden. De beste basis wordt door de opleidingen in de sector Gezondheidszorg geboden. Zo oordeelt $83 \%$ van de gediplomeerden op MBO-BBL niveau 3 van de sector Gezondheidszorg positief wat de basis om kennis en vaardigheden verder te ontwikkelen betreft. Onder de gediplomeerden van dezelfde sector, maar dan op MBO-BBL niveau 4 , is het $74 \%$ en in het $\mathrm{HBO}$ nog steeds $70 \%$.

Ondanks dat de gediplomeerden van de MBO-BOL niveau 4 sector Economie ontevreden waren met de basis om te starten op de arbeidsmarkt, zien we dat iets meer dan de helft van hen wel tevreden is als het om de basis gaat om kennis en vaardigheden verder te ontwikkelen. Dit zal dan ook een belangrijke oorzaak kunnen zijn voor het feit dat een meerderheid (65\%) na afronden van de MBO-BOL niveau 4 opleiding doorstroomt naar een vervolgopleiding in plaats van zich aan te bieden op de arbeidsmarkt.

\subsection{Opleiding: Selectiviteit}

De betrouwbaarheid waarmee het onderwijs haar studenten beoordeelt op de aanwezige competenties is van groot belang omdat deze competenties voor een groot deel bepalend zijn voor het door de school gecertificeerde eindniveau. De legitimering van het diploma is dan ook voor een groot deel gelegen in de betrouwbaarheid hiervan. Zowel onderwijsinstellingen zelf als ook werkgevers zullen er op moeten kunnen vertrouwen dat een schoolverlater met een bepaald eindcertificaat ook daadwerkelijk beschikt over de competenties die bij het betreffende diploma horen. 
Uit eerdere onderzoeken (zie bijvoorbeeld Allen et al., 2007) komt vaak een beeld van Nederlandse (hoger onderwijs) studenten naar voren die het niet best doen wat hun studiegedrag betreft. In vergelijking met studenten van andere Europese landen zouden zij relatief zelden meer werk doen dan nodig is om de tentamens te halen en proberen zij niet vaak om het hoogst mogelijke cijfer te halen (zie figuur I.4). Met andere woorden, Nederlandse studenten worden vaak als 'vrij lui dan wel resultaatgericht' gezien.

\section{Figuur 1.4}

Aandeel afgestudeerden dat meer werk tijdens de opleiding verrichtte dan nodig was om de tentamens te halen en aandeel afgestudeerden dat tijdens de opleiding naar de hoogst mogelijke cijfers streefde, $\mathrm{HBO}$ en WO, afstudeerjaar 1999-2000 (\%)

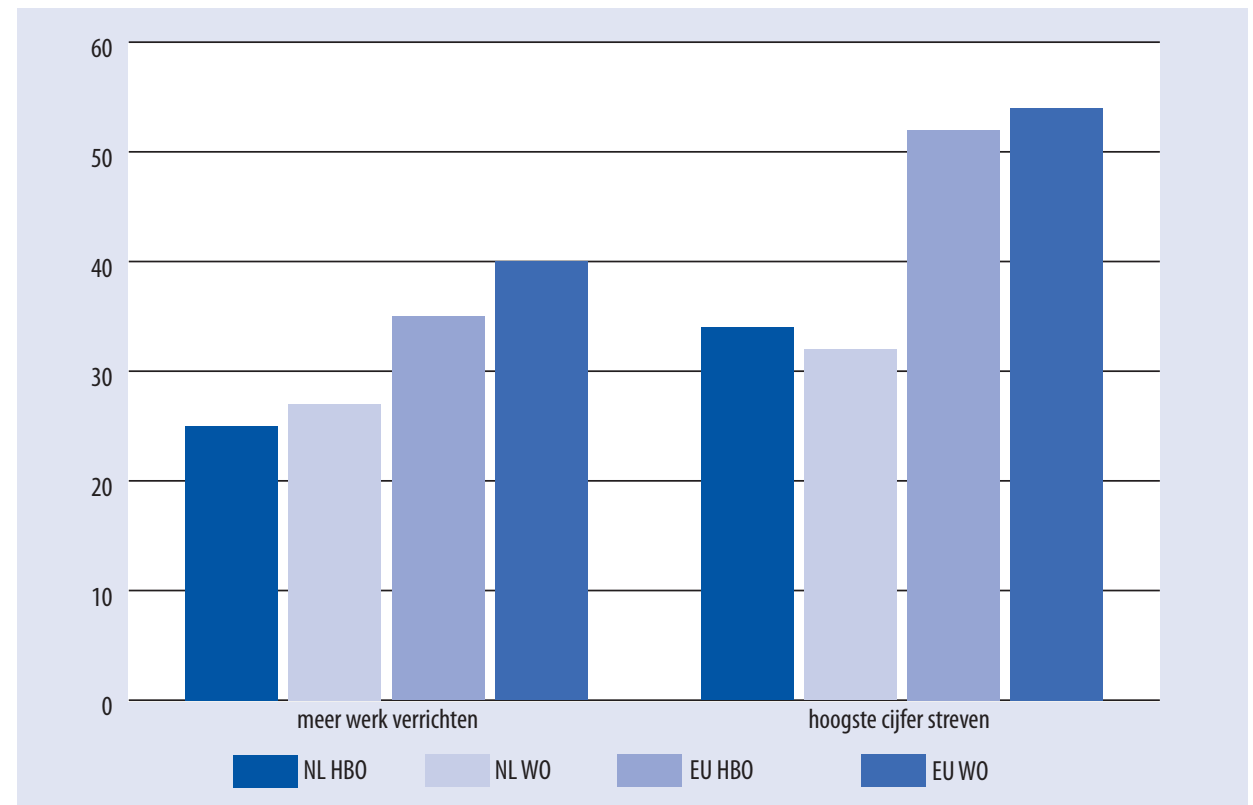

Bron: Allen et al., 2007: REFLEX HBO: afgestudeerde van het hoger beroepsonderwijs in 15 landen die aan het REFLEX onderzoek hebben deelgenomen; REFLEX WO: afgestudeerde van universiteiten in 15 landen die aan het REFLEX onderzoek hebben deelgenomen.

De vraag is echter of dit gedrag niet deels een reactie is op de manier van onderwijs geven. Om hier achter te komen is aan de schoolverlaters gevraagd om over de volgende vijf aspecten hun mening te geven: (I) de moeilijkheidsgraad van de opleiding, (2) de strengheid van de docenten bij het beoordelen van scholieren/studenten, (3) de mate waarin de opleiding uitdagend was qua niveau, (4) de mate waarin de examens en opdrachten als pittig werden ervaren en (5) de mate waarin op inzicht werd getoetst. Twee kanttekeningen zijn hierbij op zijn plaats. Allereerst dienen we ons te realiseren dat het hierbij gaat om subjectieve oordelen van de schoolverlaters zelf. Bovendien is dit gevraagd aan degenen die de opleiding succesvol hebben afgerond, en zegt het dus meer over de selectiviteit tijdens de opleiding dan over de selectiviteit bij de intrede. Scholieren die de opleiding vanwege tegenvallende studieresultaten voortijdig hebben verlaten, zullen wellicht heel anders denken over de selectie tijdens de opleiding. Niettemin geven deze indicatoren een goed beeld over de mate waarin naar het oordeel van de schoolverlaters zelf de opleiding voldoende selectief was. 
Box 1.1

Selectiviteit en schooluitval

In een eerdere rapportage (ROA, 2009) is voor het MBO stilgestaan bij de vraag in hoeverre de selectiviteit van een opleiding een invloed heeft op het afhaken van scholieren omdat ze teleurgesteld waren in de opleiding. Hiervoor zijn op sectorniveau de oordelen van de gediplomeerde schoolverlaters gekoppeld aan de redenen voor uitval onder de scholieren.

Uit de analyse kwam een aantal interessante verbanden naar voren. Opleidingssectoren in het MBO die volgens de gediplomeerde schoolverlaters opleidingen kennen die relatief uitdagend qua niveau zijn, kennen onder de ongediplomeerde schoolverlaters een kleiner aandeel van respondenten die de opleiding hebben verlaten omdat zij of een andere opleiding wilden volgen of omdat de opleiding niet aan de verwachtingen voldeed. Hetzelfde geldt voor opleidingssectoren die volgens de gediplomeerde schoolverlaters pittige examens/opdrachten kennen. Met andere woorden, qua niveau uitdagende opleidingen met pittige examens stimuleren scholieren en voorkomen daarmee dat deze teleurgesteld afhaken. De vraag is of hier niet een keerzijde aan zit, namelijk het gevaar dat uitdagende opleidingen met pittige examens een hoger percentage ongediplomeerde respondenten kennen die als niet-kunners moeten worden getypeerd, dat wil zeggen die het niveau van de opleiding niet aankunnen en daarom gedwongen worden om af te haken. De beschikbare data laten deze keerzijde echter niet zien: er lijkt geen significante correlatie te bestaan tussen het oordeel van de gediplomeerde schoolverlaters over het uitdagend karakter van de opleiding en de zwaarte van de examens/opdrachten, en het percentage ongediplomeerde respondenten dat stopte met de opleiding omdat deze te moeilijk was.

Om te beginnen is aan de schoolverlaters gevraagd om op een 7-puntschaal (van I 'veel te laag' naar 7 'veel te hoog') een oordeel te geven over de algemene moeilijkheidsgraad van de gevolgde opleiding. In figuur I.5 presenteren we het percentage dat de opleiding te makkelijk vond (antwoordcategorie I en 2 van de 7-puntschaal) per onderscheiden opleidingsniveau. De geïnteresseerde lezer vindt in tabel 6 van de Statistische Bijlage de cijfers voor de onderliggende onderwijssectoren.

I6\% van de ondervraagde gediplomeerden vindt achteraf dat de gevolgde opleiding te makkelijk was. Vergelijkbaar met de antwoorden over de diepgang van de opleiding zijn het vooral de opleidingen op de hogere MBO niveaus die als relatief makkelijk gezien worden. Zo vindt $29 \%$ van de gediplomeerden van het MBO-BOL niveau 4 dat de opleiding te makkelijk was en is dit met $23 \%$ onder de gediplomeerden van het MBO-BBL niveau 4 nog steeds bijna één op de vier. Net zoals bij het oordeel over de diepgang van de opleiding dient ook nu vermeld te worden dat onder de gediplomeerden van de niveau 4 opleidingen er ook jongeren zitten die door hadden kunnen stromen naar een hoger opleidingsniveau. Ondanks deze kanttekening mag opgemerkt worden dat zeker de MBO-BOL niveau 4 opleidingen volgens de gediplomeerden pittiger hadden mogen zijn. Binnen de opleidingen op MBO-BOL niveau 4 zijn het verder vooral de gediplomeerden van de sector Landbouw die de opleiding te makkelijk vonden (38\%) terwijl er bij de sector Gezondheidszorg aanzienlijk minder gediplomeerden deze mening zijn toegedaan namelijk $20 \%$.

Een met het $\mathrm{MBO}$ vergelijkbaar beeld zien we ook bij het VMBO. Is het gemiddeld I7\% die de opleiding te makkelijk vond, in de hoogste leerweg van het $\mathrm{VMBO}$, de theoretische leerweg, is het iets meer (20\%) terwijl het in de basisberoepsgerichte leerweg iets minder is (I4\%).

Naast een oordeel over de algemene moeilijkheidsgraad is aan de gediplomeerden ook gevraagd om een oordeel te geven over een viertal onderliggende aspecten: (I) de strengheid van de docenten in de beoordeling, (2) de pittigheid van de examens en opdrachten, (3) de 
uitdagendheid van de opleiding en (4) de mate waarin op inzicht werd getoetst. Tabel I.4 presenteert voor deze vier aspecten het percentage gediplomeerden dat een positief oordeel over de aspecten geeft.

\section{Figuur 1.5}

Moeilijkheidsgraad van opleiding (\% dat opleiding te makkelijk vond)

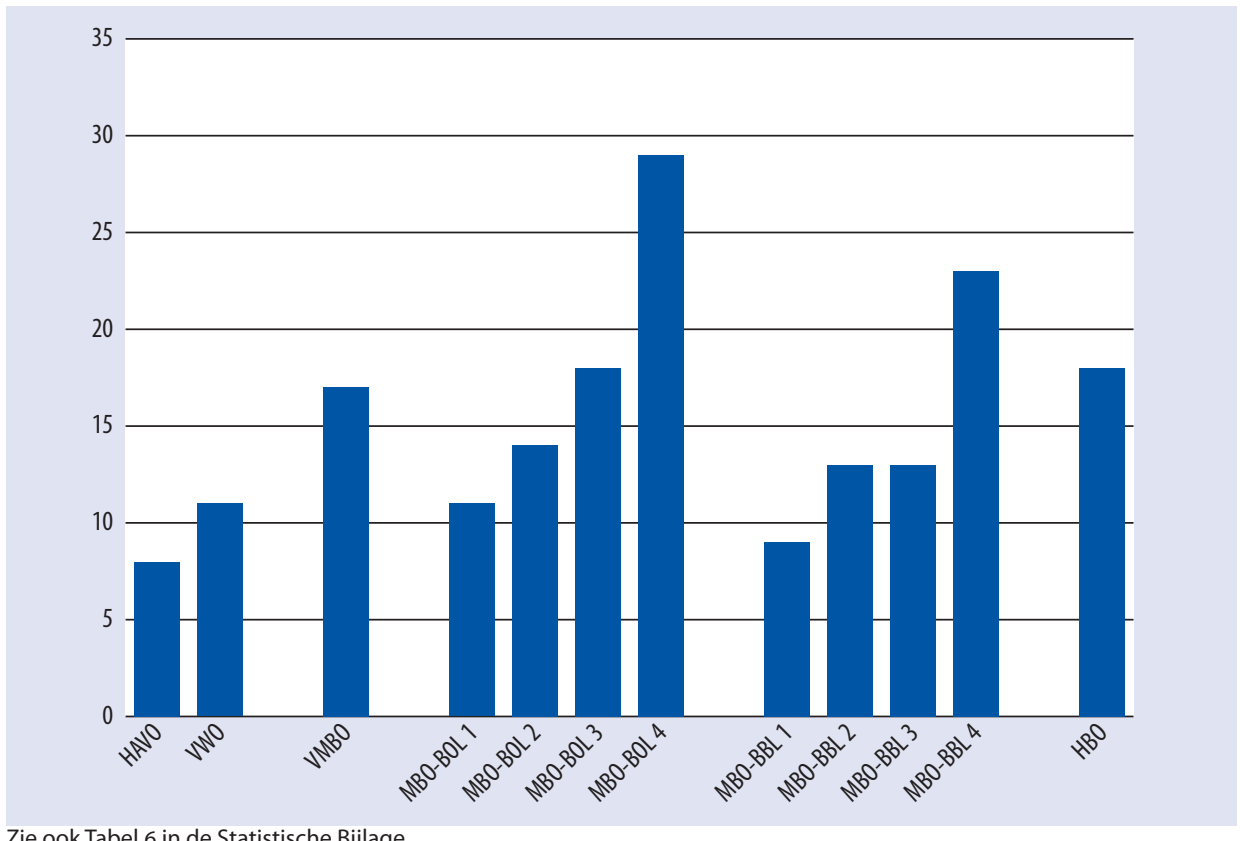

Zie ook Tabel 6 in de Statistische Bijlage

\section{Tabel 1.4}

Selectiviteit van opleiding (\% dat het eens is met de stelling)

\begin{tabular}{|lrrrr|} 
& Docenten waren streng & Examens waren pittig & Opleiding was uitdagend & Er werd op inzicht getoetst \\
\hline HAV0 & 26 & 39 & 35 & 44 \\
\hline VW0 & 27 & 32 & 42 & 55 \\
\hline VMBO & 21 & 24 & 30 & 43 \\
\hline MBO-BOL & 18 & 22 & 31 & 34 \\
\hline MBO-BBL & 18 & 29 & 37 & 44 \\
\hline HBO & 20 & 24 & 35 & 37 \\
\hline Totaal & & & 34 & 42 \\
\hline Zie
\end{tabular}

Zie ook Tabellen 7, 8, 9 en 10 in de Statistische Bijlage

Van de ondervraagde schoolverlaters vindt slechts één op de vijf dat de docenten streng waren in het beoordelen van de scholieren/studenten $(36 \%$ is het met deze stelling (helemaal) niet eens). De examens werden door iets meer (27\%) als pittig ervaren, maar ook hier is een grotere groep van respondenten $(35 \%)$ het niet eens met de stelling, en één op de drie vond de opleiding uitdagend qua niveau (een vergelijkbare groep is het hier niet mee eens). Het oordeel op de vraag of er in de opleiding op inzicht werd getoetst komt met $42 \%$ 'ja' respon- 
denten nog het dichts bij een meerderheid. Wat het algemene beeld betreft kan dan ook vastgesteld worden dat de gediplomeerden nogal kritisch zijn wat deze aspecten betreft.

\subsection{Opleiding: Studiebegeleiding en voorlichting}

Zowel studiebegeleiding als voorlichting over de mogelijke verdere studie- en beroepsmogelijkheden zijn in het middelbare onderwijs van groot belang. Goede begeleiding van scholieren kan voortijdige schooluitval terugdringen (zie ook Hoofdstuk 3) en goede voorlichting over de mogelijkheden in het verdere verloop van de onderwijs- dan wel arbeidsmarktcarrière zorgt ervoor dat de gediplomeerden hun carrière succesvol kunnen vervolgen (zie ook Hoofdstuk 2). Een goede indicatie hiervan is rechtstreeks te vinden in de antwoorden van de respondenten van meting 20IO. Zo heeft I8\% van de AVO en de VMBO gediplomeerden die ontevreden zijn met de geboden voorlichting over studiemogelijkheden de vervolgopleiding in de eerste anderhalf jaar alweer verlaten. Onder hun studiecollega's die de voorlichting neutraal dan wel positief beoordeelden is dit met I4\% (AVO) en IO\% (VMBO) duidelijk minder. Een tweede duidelijke indicatie voor het belang van goede voorlichting geeft het School-Ex programma dat in de jaren 2009 en 2010 in het MBO uitgevoerd is (zie box I.2).

\section{Box 1.2}

School-EX programma (Bron: ROA, Fact Sheet 2011/1)

Vanwege de economische crisis hebben MBO-scholen in het voorjaar van 2010 behalve de reguliere voorlichting extra activiteiten ondernomen om leerlingen te helpen bij hun studie- en beroepskeuze. Hierbij kan een tweetal typen van activiteiten onderscheiden worden: algemene activiteiten (bijvoorbeeld extra informatie verspreiden of extra aandacht door docenten voor de problematiek op de arbeidsmarkt) en persoonlijke gesprekken met leerlingen. Op basis van een onderzoek onder de gediplomeerden van het MBO (schooljaar 2009-2010) komt het volgende beeld omtrent deze activiteiten naar voren (zie ook hoofdstuk 2 voor een uitgebreidere discussie omtrent het School-Ex programma in het MBO).

In totaal geeft $53 \%$ van de respondenten aan dat ten minste één algemene activiteit heeft plaatsgevonden. Onder de gediplomeerden van niveau 1 is dit zelfs $60 \%$. Met andere woorden, scholen hebben behoorlijk wat extra inspanningen verricht om leerlingen voor te lichten. Algemene activiteiten zijn natuurlijk belangrijk maar kunnen persoonlijke gesprekken niet vervangen. Uit het onderzoek blijkt dat bijna 1 op de 2 respondenten met de school op individuele basis over zijn of haar toekomstplannen heeft gesproken. Onder de gediplomeerden van niveau 1 is dit zelfs $53 \%$. Hetgeen uit deze cijfers blijkt is ook in algemene zin uit de enquêteresultaten naar voren gekomen: scholen hebben zich met hun voorlichtingsactiviteiten met name gericht op de meest kwetsbare jongeren, namelijk de niveau 1 en 2 gediplomeerden.

Belangrijk is de vraag in hoeverre de schoolactiviteiten invloed hebben gehad op de keuze van de gediplomeerden omtrent wat zij na het behalen van het diploma zijn gaan doen. Uit het onderzoek onder de MB0-gediplomeerden van het schooljaar 2009-2010 blijkt dat voor 3 van de 4 respondenten geldt dat de schoolactiviteiten verder geen invloed hebben gehad op hun uiteindelijke keuze. Bij de anderen hebben de schoolinspanningen wel invloed gehad: maar liefst 19\% is alsnog een vervolgopleiding gaan volgen of heeft zijn of haar opleidingskeuze aangepast. Hierbij geldt dat we er rekening mee dienen te houden dat voor een groot deel van de jongeren de keuze omtrent hun toekomstactiviteit al lang vaststond. Jongeren die al een baan in het vooruitzicht hadden en jongeren die zich al voor een vervolgopleiding aangemeld hadden zullen zich door de schoolactiviteiten minder hebben laten beïnvloeden.

Figuur I.6 laat de tevredenheid van de gediplomeerde schoolverlaters zien wat de studiebegeleiding en de voorlichting betreft. Met 50\% van de gediplomeerden die tevreden zijn wat de 
voorlichting betreft en $45 \%$ wat de studiebegeleiding betreft scoort het VMBO het hoogst. Maar ook het AVO en het MBO scoren relatief gezien sterk. Zo is bij de gediplomeerden van het AVO op deze twee indicatoren zo'n $36 \%$ tevreden en is het bij de gediplomeerden van het $\mathrm{MBO} 40 \%$ (studiebegeleiding) en 34\% (voorlichting). Ondanks dat hiermee slechts een minderheid (zeer) tevreden is, kan dit, wat het $\mathrm{MBO}$ betreft, als redelijk positief gezien worden. Reden hiervoor is dat het percentage dat tevreden is aanzienlijk groter is dan het percentage dat niet tevreden is. Dit geldt niet voor het aspect 'voorlichting' op het AVO. Hier is het percentage dat niet tevreden is $(36 \%)$ even groot als het percentage dat tevreden is $(36 \%)$. Wat de voorlichting op het AVO over de verdere studiemogelijkheden betreft lijkt dan ook nog winst te halen. Zeker gezien de relatief hoge uitval van deze groep jongeren in het hoger onderwijs (zie hiervoor paragraaf I.8).

\section{Figuur 1.6}

Oordeel over studiebegeleiding en voorlichting (\%)

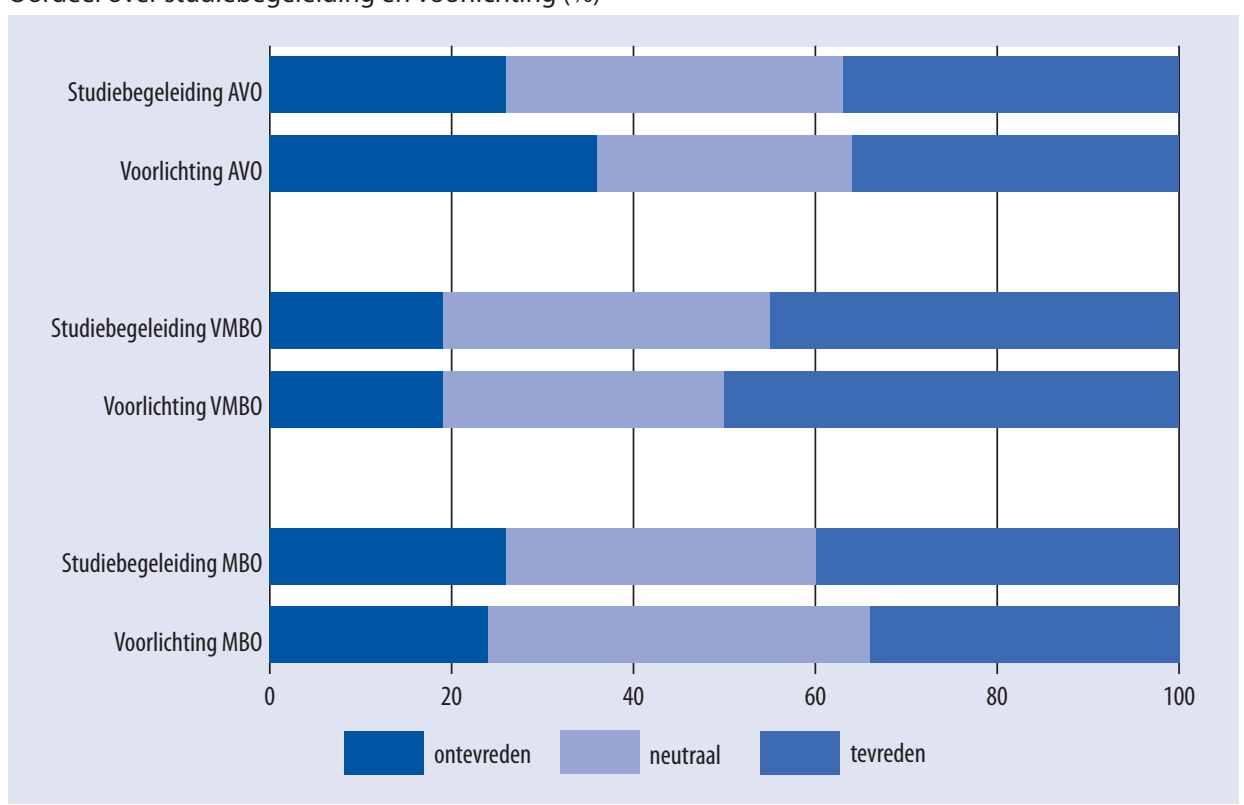

Voor jongeren die via de beroepsopleidende leerweg van het $\mathrm{MBO}$ (MBO-BOL) een opleiding volgen speelt naast de algemene studiebegeleiding de begeleiding tijdens de directe praktijkervaring, dat wil zeggen tijdens het lopen van de stage(s), een uitermate belangrijke rol. Immers, zonder praktijkervaring kunnen de jongeren hun diploma niet behalen en zullen zij zeker ook wat de competenties betreft die direct op het werkveld toepasbaar zijn tekort schieten. Het is dan ook interessant om hier kort nader op in te gaan. Tabel I.5 presenteert per opleidingsniveau van het $\mathrm{MBO}-\mathrm{BOL}$ een viertal resultaten omtrent de praktijkervaring. $\mathrm{I} 6 \%$ van de gediplomeerden van het MBO-BOL had tijdens de opleiding moeite met het vinden van een stageplaats. Het percentage dat moeite ondervond is daarbij in economisch slechte tijden iets hoger dan in economisch goede tijden maar de verschillen zijn niet groot. Jongeren die een opleiding op niveau I en 2 volgen hebben iets meer moeite dan jongeren die de opleiding op niveau 3 en 4 volgen maar ook hier zijn de verschillen eerder marginaal. Ondanks dat de verschillende economische sectoren natuurlijk verschillend hard door een 
economische crisis getroffen worden zien we geen grote verschillen tussen de gediplomeerden van de onderliggende onderwijssectoren.

\section{Tabel 1.5}

Stage vinden, inhoud en begeleiding (\%)

\begin{tabular}{|lrrrr|}
\hline & Problemen bij vinden & Tevreden met inhoud & $\begin{array}{r}\text { Tevreden met begeleiding } \\
\text { vanuit school }\end{array}$ & $\begin{array}{r}\text { Tevreden met begeleiding } \\
\text { vanuit werk }\end{array}$ \\
\hline BOL 1 & 19 & 74 & 50 & 61 \\
\hline BOL 2 & 18 & 77 & 40 & 63 \\
\hline BOL 3 & 16 & 80 & 37 & 66 \\
\hline BOL 4 & 14 & 79 & 39 & 68 \\
\hline
\end{tabular}

Wat de inhoud van de gevonden stage betreft zijn de gediplomeerden over de gehele linie gezien goed te spreken. Driekwart (niveau I) tot $80 \%$ (niveau 3) van de gediplomeerden vindt dat tijdens de stage de verschillende aspecten van het beroep waarvoor ze aan het leren zijn voldoende aan bod zijn gekomen. Wat de begeleiding betreft zijn er echter nogal wat verschillen te zien tussen de tevredenheid met de begeleiding vanuit de school (varieert tussen $37 \%$ bij de gediplomeerden van niveau 3 en $50 \%$ bij de gediplomeerden van niveau I) en de begeleiding vanuit het werk (varieert tussen de $6 \mathrm{I} \%$ bij de gediplomeerden van niveau I en de $68 \%$ bij de gediplomeerden van niveau 4). Opvallend is dat de begeleiding vanuit de school daarmee relatief beter beoordeeld wordt op de lage niveaus en de begeleiding vanuit het werk relatief beter beoordeeld wordt op de hoge niveaus. Het lijkt dat de relatief minder goede begeleiding vanuit het werk op de lage niveaus gecompenseerd wordt door de begeleiding vanuit de school terwijl dit op de hogere niveaus minder noodzakelijk is.

\subsection{Vervolgonderwijs: kwalificerende vervolgtrajecten}

Al voor het behalen van het diploma staan de schoolverlaters voor een belangrijke keuze: bieden zij zich aan op de arbeidsmarkt of vervolgen zij hun onderwijscarrière? In de paragrafen I.6 tot en met I.8 staan de gediplomeerden centraal die voor de tweede optie hebben gekozen. Hierbij gaat het zowel om degenen die de studie vervolgen in een volledige dagopleiding als degenen die werken en leren combineren via een duale opleiding. De doorstroom naar vervolgonderwijs verschilt per onderwijsniveau. Daarom wordt eerst de doorstoom binnen het onderwijs in kaart gebracht. In figuur I.7 staat een overzicht van de kwalificerende vervolgtrajecten in het onderwijs van de gediplomeerde schoolverlaters per onderwijssoort. Vanwege de duidelijkheid zijn in de figuur de BOL en BBL niveaus samengevoegd en zijn alleen vervolgtrajecten met een aandeel van minstens $5 \%$ van de respondenten opgenomen.

Vanuit het AVO stroomt het overgrote deel van de gediplomeerde schoolverlaters door naar een vervolgopleiding. Van de totale groep HAVO respondenten is $79 \%$ doorgestroomd naar een HBO opleiding. Van de VWO'ers is I4\% naar het $\mathrm{HBO}$ gegaan, terwijl het merendeel $(73 \%)$ voor een studie in het WO heeft gekozen. ${ }^{5}$ Van de gediplomeerde VMBO respon-

5. Van de gediplomeerden van het HAVO heeft I4\% gekozen om niet rechtstreeks een vervolgopleiding te starten. Bij de gediplomeerden van het VWO is dit $12 \%$. In beide gevallen is dit een lichte stijging tegenover het resultaat uit meting 2009. In de meeste gevallen gaat het hierbij om jongeren die een tussenjaar (reizen, taalcursus) 
denten gaat minder dan 5\% niet verder met een vervolgopleiding. Deze groep verlaat, ten minste in eerste instantie, het onderwijs dus zonder een startkwalificatie verkregen te hebben. Dit wil overigens niet zeggen dat deze schoolverlaters voorgoed verloren zijn voor het onderwijs: ze zijn in ieder geval niet direct na het behalen van hun VMBO diploma doorgestroomd naar een vervolgstudie.

\section{Figuur 1.7}

Kwalificerende vervolgtrajecten na het verlaten van de opleiding

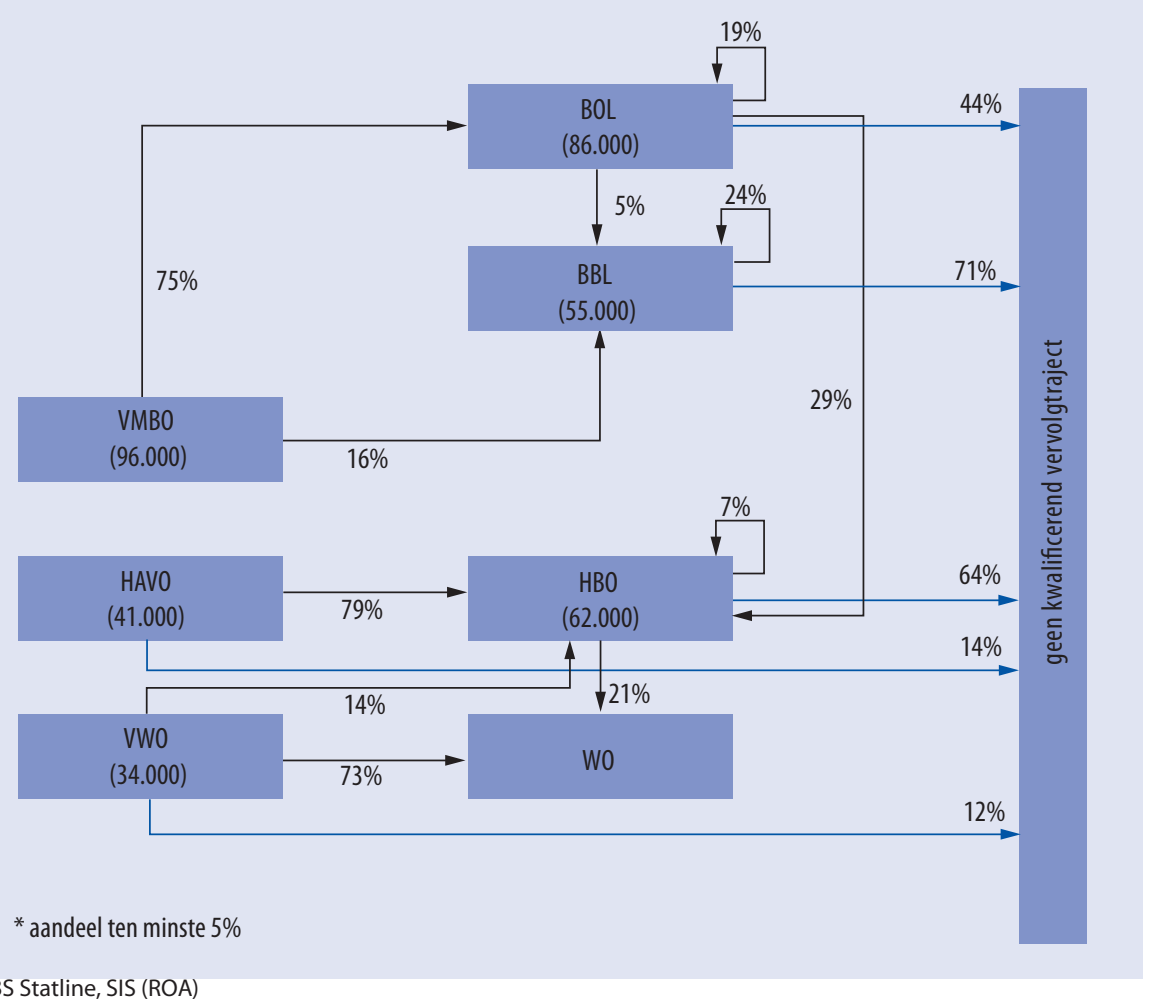

Bron: CBS Statline, SIS (ROA)

Van de BOL respondenten geeft iets meer dan de helft (56\%) aan begonnen te zijn aan een nieuwe opleiding. Bij de BBL is dit aanzienlijk minder (29\%). Van de totale groep BOL gediplomeerden kiest daarbij $29 \%$ voor een studie in het $\mathrm{HBO}$, terwijl $19 \%$ binnen het BOL blijft en $5 \%$ overstapt naar het BBL. Van de BBL'ers die verder leren blijft het merendeel een duaal traject volgen op MBO niveau. Van de Hbo'ers gaat 36\% verder met een opleiding, waarvan de meesten met een universitaire opleiding. De doorstroom van een $\mathrm{HBO}$ bachelor opleiding naar een WO Master opleiding vereist daarbij in meer dan de helft van de gevallen het volgen van een pre-master studie.

Mede met het oog op het al dan niet verkrijgen van een startkwalificatie is de doorstroom van het VMBO naar het MBO een belangrijke peiler in het Nederlandse onderwijsstelsel. Daarbij speelt niet alleen de vraag of men voor een kwalificerend vervolgtraject kiest een

nemen voordat zij aan de vervolgopleiding beginnen. Slechts een uiterst klein aandeel hiervan keert niet terug in het onderwijs. 
belangrijke rol, maar ook, indien dit vervolgtraject in het $\mathrm{MBO}$ plaatsvindt, voor welk niveau men heeft gekozen. De doorstroom naar een bepaald MBO niveau is daarbij sterk afhankelijk van de gevolgde VMBO leerweg (zie figuur I.8).

\section{Figuur 1.8}

Kwalificerende MBO-vervolgtrajecten na het verlaten van de VMBO-opleiding

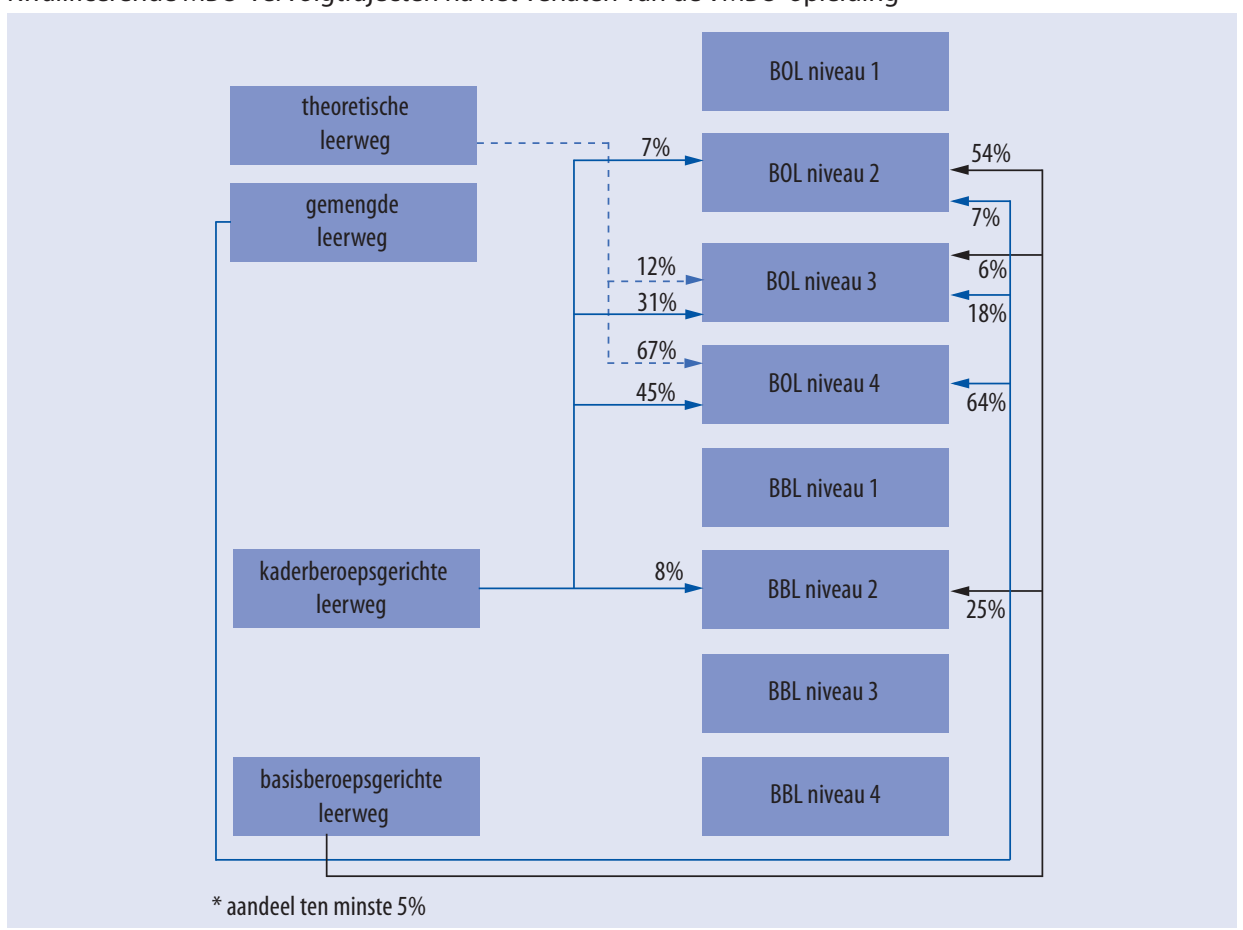

De gediplomeerden van de VMBO basisberoepsgerichte leerweg - linkerzijde in figuur I.8 - gaan weliswaar het minst vaak verder met een nieuwe opleiding, $5 \%$ van hen gaat geen vervolgstudie doen, maar de verschillen met de andere VMBO leerwegen zijn klein. In het vorige meetjaar waren de verschillen tussen de basisberoepsgerichte leerweg en de andere VMBO leerwegen aanzienlijk groter als het gaat om het percentage niet verder lerende gediplomeerden. Van de wel verder lerende VMBO'ers met een basisberoepsgerichte opleiding gaat $54 \%$ een BOL niveau 2 opleiding volgen en kiest $25 \%$ voor een niveau 2 opleiding in de BBL. De gediplomeerden van de kaderberoepsgerichte leerwegen en de gemengde leerwegen vinden in overgrote meerderheid hun weg naar BOL niveau 3 en 4 opleidingen. Dit geldt ook voor de jongeren die een VMBO-tl diploma op zak hebben en voor het MBO kiezen.

\subsection{Vervolgonderwijs: Voorbereiding en aansluiting}

Een succesvol vervolg in de onderwijsloopbaan vereist een goede voorbereiding op de mogelijke vervolgopleidingen. In paragraaf I.4 hebben we daar al aandacht aan besteed en laten zien dat goede voorlichting de kans op het voortijdig verlaten van de vervolgopleiding verlaagt. In deze paragraaf staan we achtereenvolgens voor de gediplomeerden van het AVO 
en de gediplomeerden van het VMBO nader stil bij deze voorbereiding. Echter, voordat we op deze voorbereiding ingaan, laat figuur I.9 zien hoe tevreden de gediplomeerden zijn met de aansluiting tussen de gevolgde opleiding en de vervolgopleiding.

\section{Figuur 1.9}

Aansluiting met vervolgonderwijs (\%)

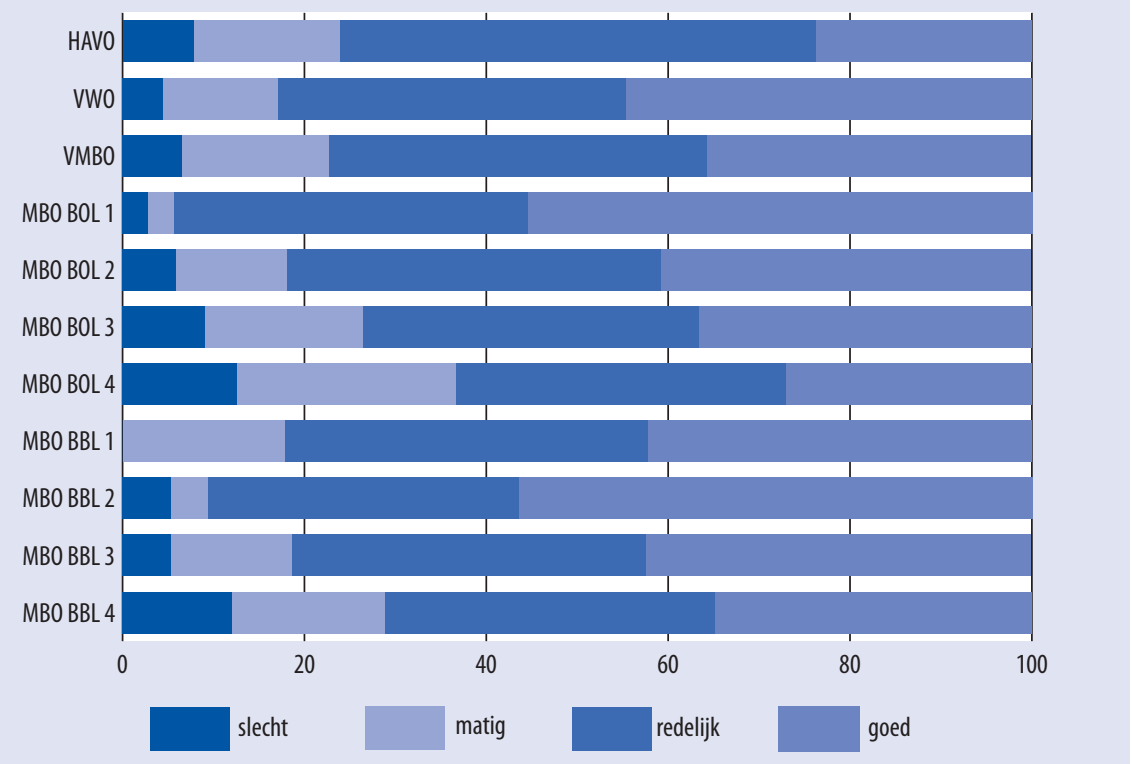

Zie ook Tabel 12 in de Statistische Bijlage

Op alle onderwijsniveaus zien we dat een duidelijke meerderheid van de gediplomeerden die hun onderwijscarrière hebben voortgezet de aansluiting tussen gevolgde opleiding en vervolgopleiding redelijk of goed vindt. Slechts in een geval, MBO-BOL niveau 4, vindt meer dan één op de drie de aansluiting matig dan wel slecht. Bij de gediplomeerden van het MBO-BBL niveau 4 is het zo'n $28 \%$ en bij de gediplomeerden van het HAVO bijna één op de vier. Aangezien deze drie groepen gediplomeerden in de regel doorstromen naar het HBO lijken deze cijfers een iets matigere overstap naar het HBO dan andere opleidingen aan te geven.

$\mathrm{Na}$ deze korte algemene indruk wat de aansluiting tussen gevolgde opleiding en vervolgopleiding betreft, staan we nader stil bij de voorbereiding van de gediplomeerde schoolverlaters van het $\mathrm{AVO}$ en het VMBO op de gekozen vervolgopleiding. Voor beide groepen kijken we naar de volgende twee punten: I) een goede voorbereiding begint bij de informatie over de vaardigheden die in een vervolgstudie vereist zijn en (2) de vraag of de gevolgde opleiding de gediplomeerden goed op de vervolgopleiding heeft voorbereid.

\section{HAVO en VWO}

Om informatie betreffende de vereiste vaardigheden inzichtelijk te maken is aan de gediplomeerden die doorgestroomd zijn naar een vervolgopleiding gevraagd op een aantal aspecten aan te geven op welke niveau deze in de vervolgopleiding vereist zijn. Figuur I.Io laat voor 
degenen die vanuit het AVO doorgestroomd zijn naar het hoger onderwijs het percentage van de gediplomeerden zien dat aangeeft dat een hoog niveau van een bepaalde vaardigheid in de vervolgopleiding vereist is. We onderscheiden daarbij vervolgopleidingen in het $\mathrm{HBO}$ (HBO bachelor) en WO (WO bachelor).

\section{Figuur 1.10}

Vereiste competenties in HBO bachelor en WO bachelor (\% dat aangeeft dat competentie op (heel) hoog niveau is vereist)

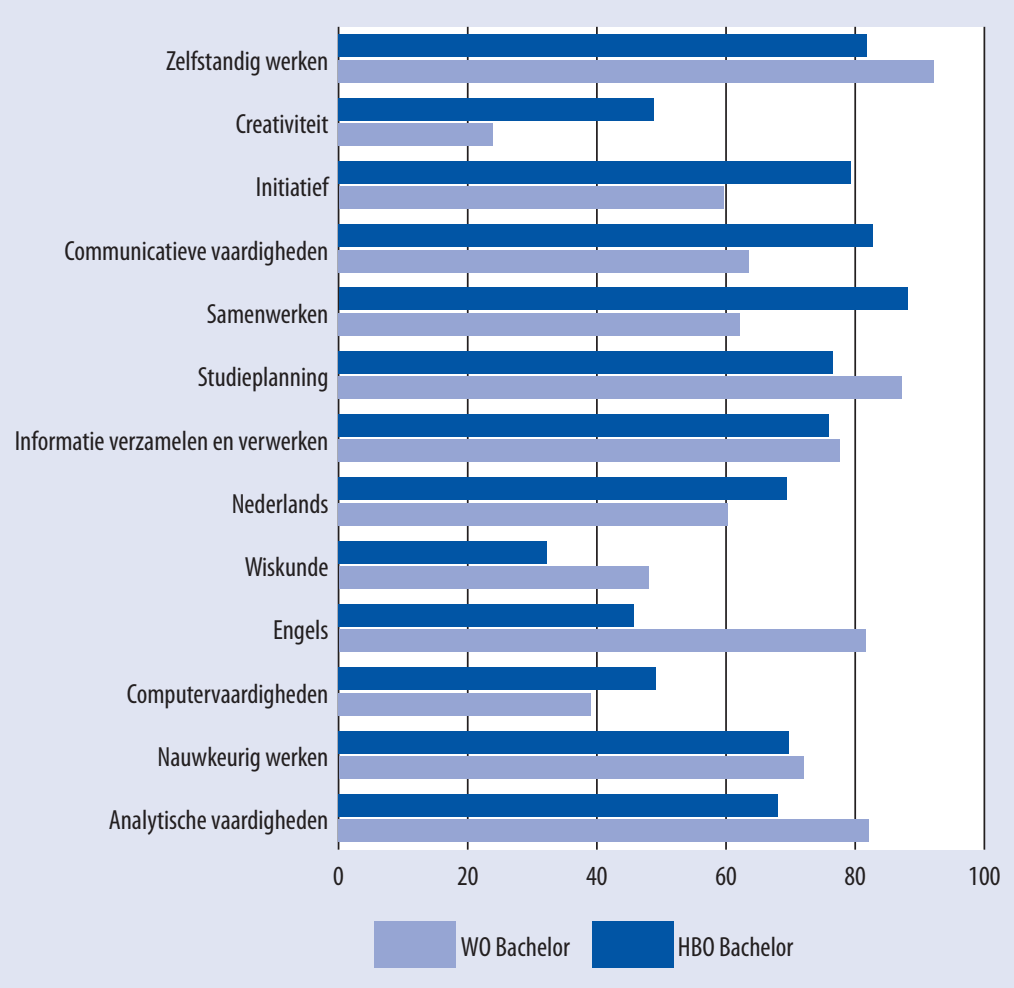

Bij 6 van de I3 vaardigheden geven ten minste $75 \%$ van de gediplomeerden die een $\mathrm{HBO}$ bacheloropleiding volgen aan dat een hoog niveau vereist is: Samenwerken, Communicatieve vaardigheden, Initiatief nemen, Zelfstandig werken, Studieplanning en Informatie verzamelen en verwerken. De laatste drie van deze vaardigheden worden ook volgens minimaal $75 \%$ van de gediplomeerden die een WO bacheloropleiding volgen op een hoog niveau vereist. In WO bacheloropleidingen zijn daarnaast analytische vaardigheden en Engelse taalvaardigheden op een vergelijkbaar hoog niveau vereist. Engels lijkt minder van belang in $\mathrm{HBO}$ opleidingen. Dit geldt echter niet voor HBO bachelor opleidingen in de sectoren Techniek en Economie. Wiskunde lijkt in eerste instantie minder van belang in het hoger onderwijs ( $48 \%$ van de respondenten die een WO bacheloropleiding volgen geeft aan dat wiskunde op een hoog niveau vereist is en bij de $\mathrm{HBO}$ bacheloropleidingen is dit slechts 32\%). Dit geldt echter niet voor jongeren die doorstromen naar de hogere onderwijssectoren Techniek en Economie. In deze twee sectoren (zowel op HBO als op WO niveau) wordt volgens meer dan 8 op de IO respondenten wiskunde op een hoog niveau vereist. 
Hoe goed heeft het algemeen voortgezet onderwijs de jongeren nu voorbereid op deze competenties. Figuur I.II laat de antwoorden zien van de gediplomeerden van het HAVO en het VWO op de vraag hoe zij 'alle aspecten overziend' de voorbereiding op deze vervolgopleiding beoordelen.

\section{Figuur 1.11}

Voorbereiding op hoger onderwijs (\%) naar type vervolgonderwijs

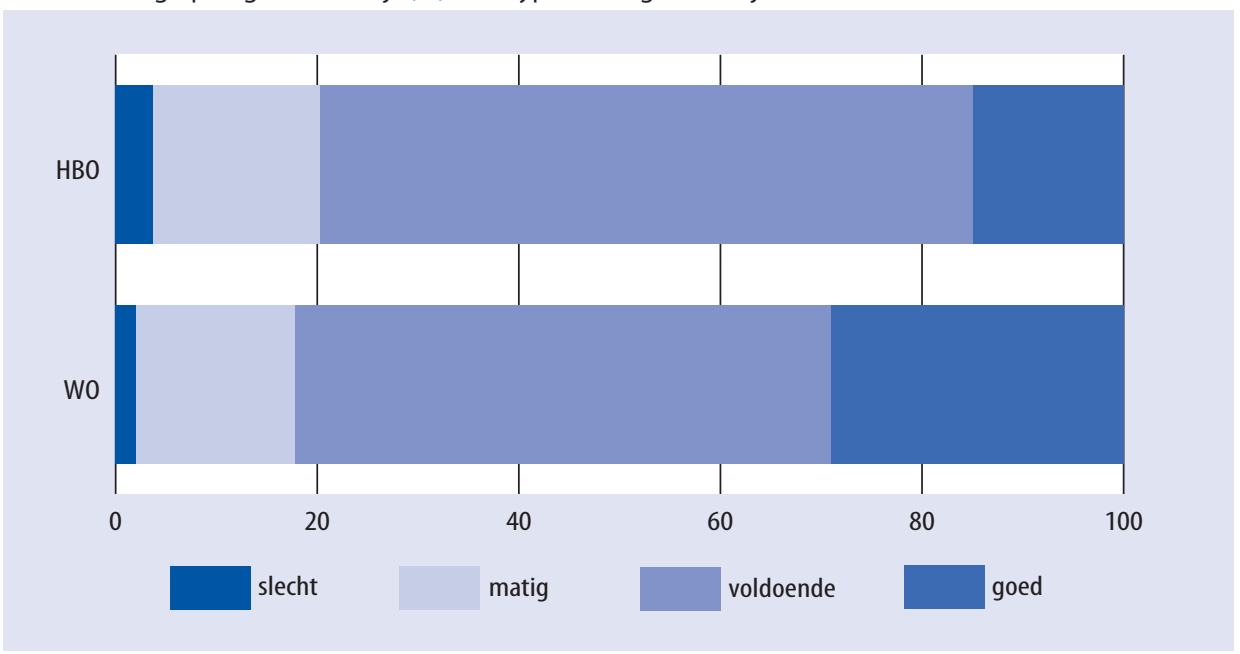

I5\% van de gediplomeerden die in het $\mathrm{HBO}$ hun onderwijscarrière voortgezet heeft ondervond de aansluiting als goed en nog eens zo'n $65 \%$ geeft als oordeel een 'voldoende'. Overigens zijn de VWO'ers die doorstromen naar het $\mathrm{HBO}$ aanzienlijk positiever over de voorbereiding dan de Havisten. Zo vindt van de VWO'ers die in het $\mathrm{HBO}$ instromen $36 \%$ dat de voorbereiding goed was en $61 \%$ dat de voorbereiding voldoende was. Bij de Havisten die in het $\mathrm{HBO}$ instromen zijn de cijfers I2\%, respectievelijk, 65\%. Van de gediplomeerden die een vervolgopleiding in het WO zijn gaan volgen vindt zo'n $30 \%$ de voorbereiding goed en nog eens $53 \%$ geeft een 'voldoende'.

Vaardigheden om de studie beter te plannen is zowel onder de jongeren die een opleiding in het $\mathrm{HBO}$ als onder de jongeren die een opleiding in het WO zijn gaan volgen de belangrijkste vaardigheid waaraan in het HAVO/VWO meer aandacht besteed had moeten worden. Volgens de jongeren die in het $\mathrm{HBO}$ ingestroomd zijn dient in het $\mathrm{VO}$ ook meer aandacht aan zelfstandig werken, communicatieve vaardigheden en samenwerken besteed te worden. Jongeren die in het WO ingestroomd zijn melden dat er naast studieplanning vooral meer aandacht aan analytische vaardigheden, Engelse taalvaardigheden en zelfstandig werken nodig was geweest.

VMBO

$\mathrm{Na}$ afronding van het VMBO heeft een leerling verschillende mogelijkheden bij de keuze voor een vervolgopleiding. De meest voor de hand liggende vorm van vervolgopleiding is een MBO-BOL of een MBO-BBL opleiding. Voor de gediplomeerden van de theoretische leerweg van het VMBO is verder een HAVO opleiding een reële optie. Om een goede voorbereiding op deze opties te bieden is het ook hier van belang om te weten welke vaardigheden van de 
gediplomeerden van het VMBO in deze opleidingen vereist worden. Om hier inzicht in te krijgen is, vergelijkbaar met de enquête onder de AVO gediplomeerden, aan de VMBO gediplomeerden gevraagd om voor een aantal vaardigheden aan te geven in hoeverre ze deze in de vervolgopleiding nodig hebben. Figuur I.I2 laat per type vervolgopleiding het percentage van de respondenten zien dat aangeeft dat een bepaalde vaardigheid op een hoog niveau nodig is.

\section{Figuur 1.12}

Vereiste vaardigheden in vervolgopleiding van VMBO-ers (\% dat meldt dat vaardigheid op (heel) hoog niveau is vereist)

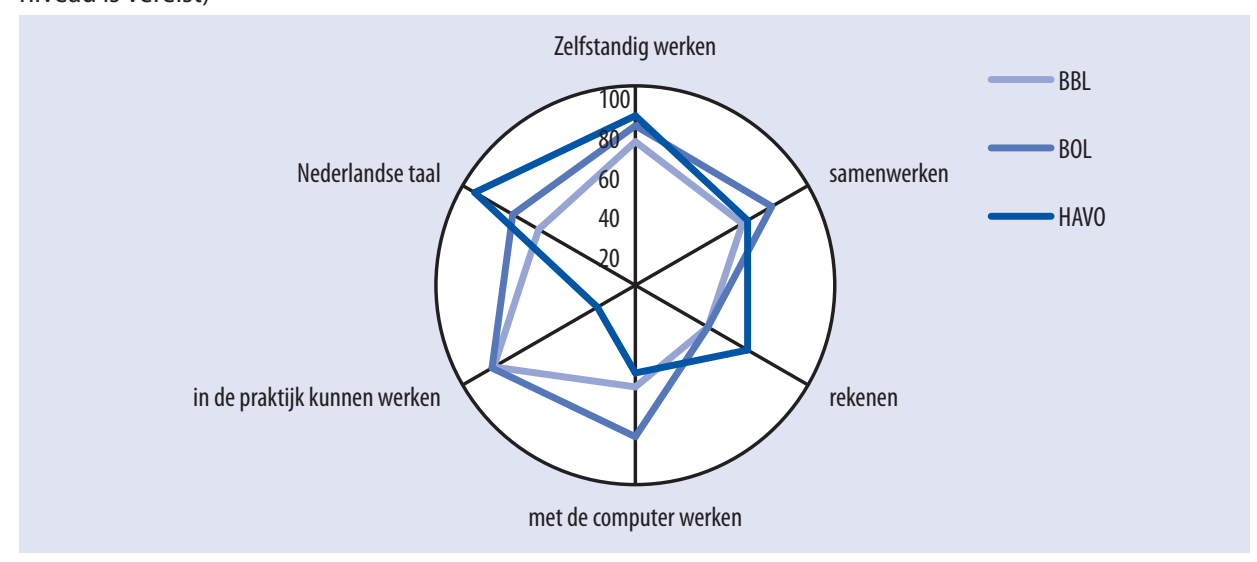

Meer dan $80 \%$ van de gediplomeerden die in het HAVO instroomt geven aan dat zelfstandig werken op een hoog niveau vereist wordt en $93 \%$ meldt dat de Nederlandse taal een uitermate belangrijke rol speelt. Terwijl zelfstandig werken ook in het MBO-BOL, en in iets mindere mate, in het $\mathrm{MBO}-\mathrm{BBL}$ een belangrijke rol speelt, is er bij het gebruik van de Nederlandse taal een veel duidelijker onderscheid tussen het $\mathrm{MBO}$ en het HAVO. In het MBO-BOL geeft $7 \mathrm{I} \%$ aan dat de Nederlandse taal (heel) veel nodig is, terwijl dit in het MBO-BBL door slechts $5 \mathrm{I} \%$ van de respondenten vermeld wordt. Niet verrassend spelen bij de MBO-opleidingen (BOL en BBL) de vaardigheid om in de praktijk te kunnen werken een grote rol, terwijl dit in het HAVO van marginaal belang lijkt te zijn.

Gezien de vereiste vaardigheden in het vervolgonderwijs, hoe vinden de gediplomeerden van het VMBO dat zij, alles overziend, voorbereid zijn (zie figuur I.I3)? 


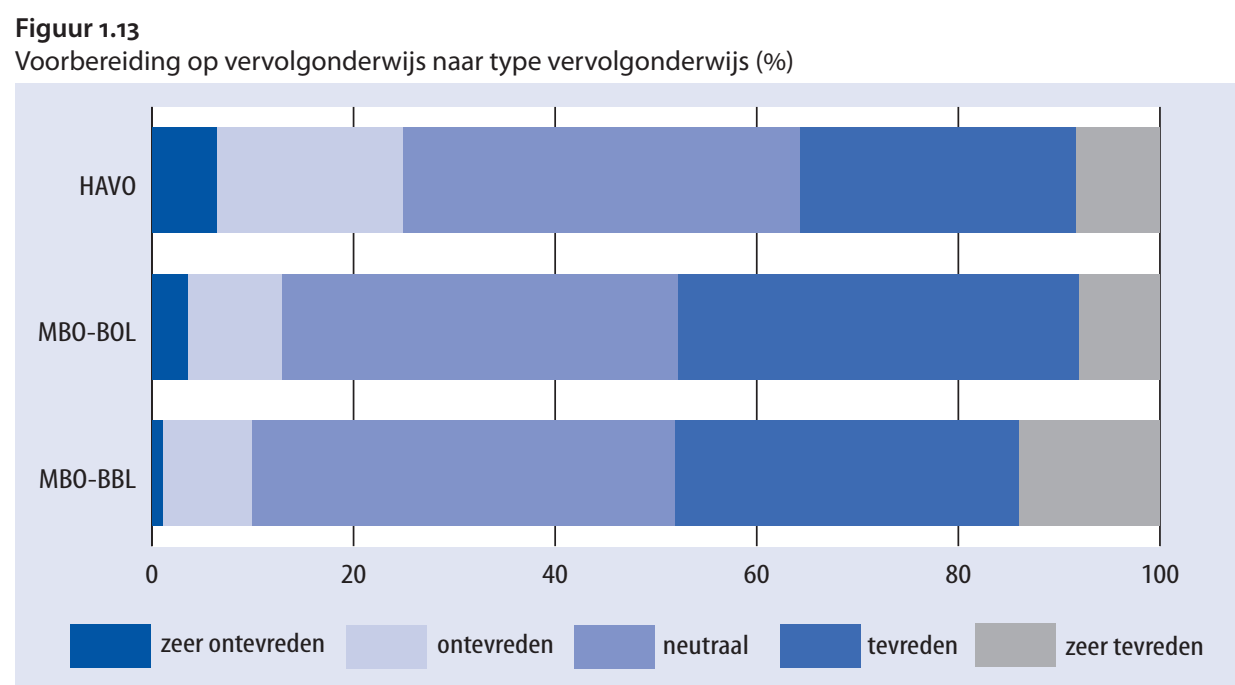

Van de gediplomeerde VMBO-ers die doorgestroomd zijn naar het $\mathrm{MBO}$ is net iets minder dan de helft (zeer) tevreden over de voorbereiding en geeft nog eens zo'n $40 \%$ een neutraal oordeel. Van de doorstromers naar het MBO-BBL is dan ook slechts één op de tien (zeer) ontevreden en van de doorstromers naar het MBO-BOL is het zo'n $13 \%$. De gediplomeerden die doorgestroomd zijn naar het HAVO zijn iets kritischer wat de voorbereiding betreft. Van hen is 'slechts' zo'n $36 \%$ (zeer) tevreden en is één op de vier (zeer) ontevreden.

\subsection{Vervolgonderwijs: Succes}

Zoals al eerder ter sprake is gekomen, is één van de functies van onderwijs het voorbereiden van leerlingen op een eventueel vervolgtraject in het onderwijs. Om het succes hiervan te meten, kijken we naar het percentage dat op moment van enquêtering (ongeveer anderhalf jaar na het behalen van het diploma) de vervolgopleiding alweer heeft verlaten. Omdat het verlaten van de vervolgopleiding niet gelijk staat aan het verlaten van het onderwijs maken we daarbij een onderscheid tussen het wisselen van de vervolgopleiding en het echte verlaten van het onderwijs. In figuur I.I4 staat het aandeel gediplomeerden dat de vervolgopleiding voortijdig heeft verlaten zonder direct aan een andere opleiding begonnen te zijn (de netto uitval) alsmede het aandeel dat van studie gewisseld is.

In totaal geeft II\% van de gediplomeerden aan alweer gestopt te zijn met de aanvankelijk gekozen vervolgopleiding. Van alle onderwijsniveaus stoppen de havisten met $16 \%$ het vaakst voortijdig met de vervolgopleiding, gevolgd door de VWO'ers (I4\%). ${ }^{6} \mathrm{Bij}$ de gediplomeerden van vrijwel alle andere onderwijsniveaus liggen deze percentages anzienlijk lager. Bij het $\mathrm{VMBO}$ is dit IO\%, bij het MBO-BOL varieert het tussen 6\% (niveaus 2 en 3) en II\% (niveaus

6. Het percentage is daarbij voor zowel de Havisten als de VWO'ers duidelijk lager dan in meting 2009. In 2009 stopte respectievelijk $22 \%$ en $20 \%$ voortijdig. Een vergelijking met eerdere jaren laat zien dat het percentage dat de vervolgopleiding vroegtijdig verlaat licht negatief gecorreleerd is met de economische groei op dit moment. Dit zal dan ook gedeeltelijk de daling kunnen verklaren. 
I en 4), bij het MBO-BBL varieert het tussen $5 \%$ (niveaus 2 en 3 ) en II\% (niveau 4) en bij het $\mathrm{HBO}$ is het $7 \%$. Wellicht nog belangrijker dan het percentage 'afhakers' vlak na aanvang van de vervolgstudie is het percentage van hen dat ook niet aan een andere studie is begonnen. Met andere woorden welk deel van deze uitvallers zijn studiewisselaars en welk deel heeft op het enquêtemoment daadwerkelijk het onderwijs verlaten. Van de II\% met de vervolgopleiding gestopte schoolverlaters is gemiddeld $7 \%$-punt studiewisselaar, dat wil zeggen iemand die nog niet uit het vervolgonderwijs verdwijnt maar in eerste instantie een verkeerde studiekeuze lijkt te hebben gemaakt. Er is relatief het vaakst sprake van echte uitval bij de doorstromers vanuit het $\mathrm{HBO}$ die natuurlijk al een zeer arbeidsmarktrelevant diploma bezitten. De relatief grote uitval onder de VO-ers van $15 \%$ bestaat gelukkig voor het merendeel uit studiewisselaars: de netto uitval in deze groep blijkt uiteindelijk slechts $3 \%$ te zijn.

Figuur 1.14

Netto uitval en studiewisselaars (\%)

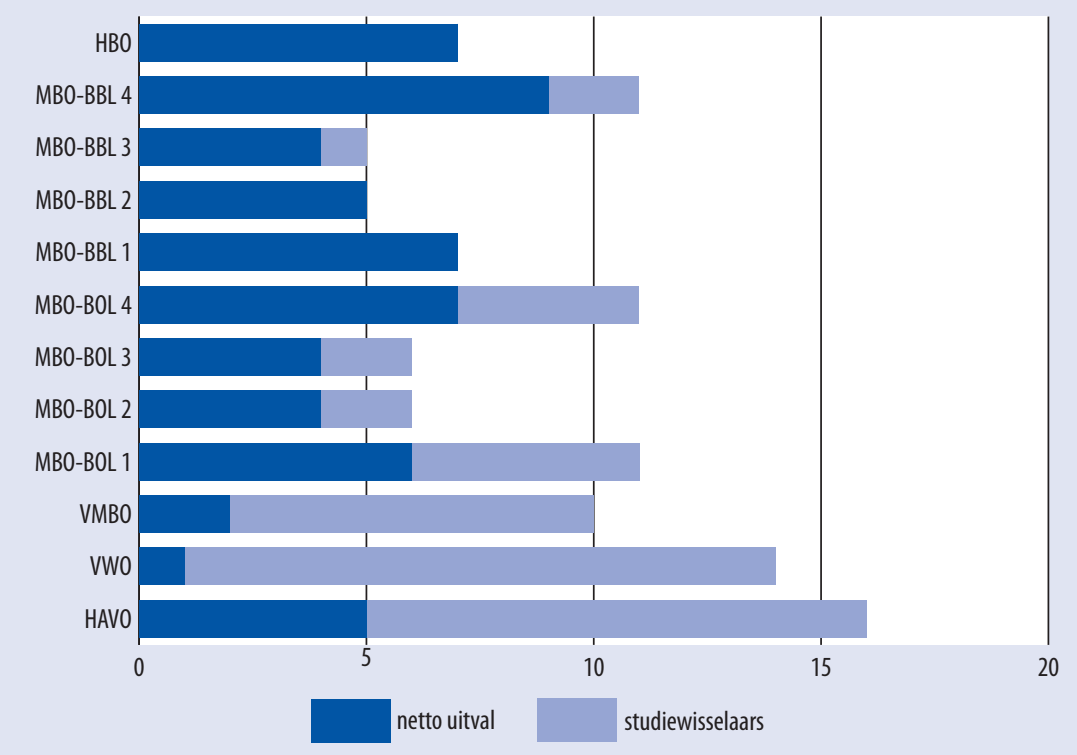

Zie ook tabel 13 in de Statistische Bijlage

Door als uitgangspunt niet de sector van de gevolgde, afgeronde opleiding te nemen maar de sector van de gekozen vervolgopleiding kan gekeken worden in welke opleidingssectoren men te kampen heeft met hoge uitval. Uit een nadere analyse van de onderzoeksresultaten blijkt dat er over het gehele MBO-BOL onderwijs een netto uitval is van ongeveer $7 \%$. Er is met name in de niveau 2 en 3 techniekopleidingen sprake van een hoge uitval van studenten die niet meteen aan een andere studie beginnen. Op niveau 2 techniek geldt dit voor $9 \%$ van de instroom, op niveau 3 voor $13 \%$. Binnen de vervolgopleidingen op MBO-BBL niveau is er met name een hoge netto uitval in de niveau 2 landbouwsector ( $9 \%$ en de niveau 3 economie vervolgopleidingen (I2\%). Over het BBL als geheel ligt de netto uitval net iets hoger dan in de BOL. Omdat het percentage studiewisselaars echter in de BBL weer lager is dan in de BOL is de bruto uitval in de BBL uiteindelijk iets lager dan in de BOL. In het $\mathrm{HBO}$ is de netto uitval 6\%. Hierbij kennen de HBO sectoren taal en cultuur (2\%) en onderwijs (3\%) de laagste percentages netto uitvallers. In het wetenschappelijk onderwijs ligt de netto uitval op net $3 \%$, 
ongeveer IO\% van de instromers stopt weliswaar met de studie maar begint vervolgens aan een andere opleiding. Tussen de WO sectoren zijn er echter wel aanzienlijke verschillen. Zo is de netto uitval bijvoorbeeld in de sectoren landbouw en techniek in beide gevallen $\mathrm{I} \%$ maar de bruto uitval in de eerste sector slechts $2 \%$ en in de sector techniek I $8 \%$.

Voor de studiewisselaars is de reden voor het stoppen met de vervolgopleiding duidelijk. Voor de andere groep uitvallers zijn er verschillende redenen voor het stoppen met de studie. Deze groep bestaat overigens niet in zijn geheel uit zogenaamde voortijdig schoolverlaters. Een groot deel van deze groep dreigt weliswaar voor het onderwijs verloren te gaan maar is wel in het bezit van een diploma op minimaal MBO niveau 2. In hoofdstuk 3 van dit rapport wordt specifiek ingegaan op de problematiek van de voortijdig schoolverlaters.

Als belangrijkste reden (zie tabel I.6) voor het stoppen met de vervolgstudie worden motivatieproblemen genoemd (32\%). Daarnaast worden de lessen niet interessant genoeg gevonden en wordt de organisatie van de studie als slecht ervaren. Met name op dit laatste punt zou er voor onderwijsinstellingen dus nog iets te winnen zijn. Als vierde belangrijke reden voor het stoppen met de studie wordt de moeilijkheidsgraad van de opleiding genoemd.

Tabel 1.6

Redenen voor voortijdig verlaten opleiding (\% genoemd, meerdere antwoorden mogelijk)

\begin{tabular}{|l|l|}
\hline onvoldoende gemotiveerd & $32 \%$ \\
\hline lessen niet interessant genoeg & $27 \%$ \\
\hline organisatie was slecht & $25 \%$ \\
\hline opleiding te moeilijk, te specialistisch & $23 \%$ \\
\hline gestopt vanwege persoonlijke problemen & $15 \%$ \\
\hline passend werk aangeboden gekregen & $9 \%$ \\
\hline reisafstand bezwaarlijk & $5 \%$ \\
\hline combinatie met thuissituatie te zwaar & $5 \%$ \\
\hline
\end{tabular}

\subsection{Arbeidsmarkt: Kans op werk w $^{7}$}

De overgang van het onderwijs naar de arbeidsmarkt kan vanzelfsprekend niet los gezien worden van de algemene macro-economische ontwikkelingen. Aan het begin van deze paragraaf is het dan ook goed om kort stil te staan bij de macro-economische context van de jaren 2008 - 20IO. We beperken ons tot deze periode aangezien dit de jaren zijn waar de gediplomeerde schoolverlaters die in dit hoofdstuk centraal staan:

a. hun diploma hebben behaald (schooljaar 2008 - 2009)

b. zich voor het eerst op de arbeidsmarkt aangeboden hebben en

c. geënquêteerd zijn (najaar 20IO).

Figuur I.I5 laat zien dat de economische groei van 2008 werd afgelost door een sterke economische neergang (negatieve groei van $3.4 \%$ in 2009). Het jaar 2010 laat aan het begin een zwak herstel zien dat zich vanaf het $2^{\mathrm{e}}$ kwartaal van 2010 sterker heeft doorgezet.

7. De analyses omtrent de arbeidsmarktintrede beperken zich tot de groep gediplomeerden van het $\mathrm{MBO}$ en de afgestudeerden van het HBO. De arbeidsmarkt van de gediplomeerden van het VMBO die rechtstreeks na het behalen van het diploma de arbeidsmarkt betreden wordt kort in Box I.4 besproken. 
De jongeren die in dit hoofdstuk centraal staan hebben hun diploma in het schooljaar 20082009 behaald. Voor het gros van hen was de diploma-uitreiking in het voorjaar/zomer van 2009. Zij dienden zich dan ook op de arbeidsmarkt aan te bieden op het moment dat de economische crisis op zijn hoogtepunt was. De vraag is dan ook of zij snel betaald werk konden vinden. Echter, op moment van enquête (najaar 20IO) laat figuur I.Is alweer een redelijk stabiele groei van de Nederlandse economie zien wat ten goede kan komen aan de kans op werk anderhalf jaar na het behalen van het diploma.

Om te beginnen staan we stil bij de werkloosheid direct na afronden van de opleiding (voorjaar/zomer 2009). We kijken dus niet naar de werkloosheid op het moment van enquêteren maar op het moment van intrede op de arbeidsmarkt. Om het effect van de economische crisis enigszins in kaart te brengen staat in tabel I.7 niet alleen het percentage van meting 2010 maar ook het percentage van meting 2009 (schooljaar 2007/2008) weergegeven. Het $2007 / 2008$ cohort schoolverlaters heeft de arbeidsmarkt in het algemeen nog net voor de economische crisis betreden.

\section{Figuur 1.15}

Economische groei Nederland (\%)

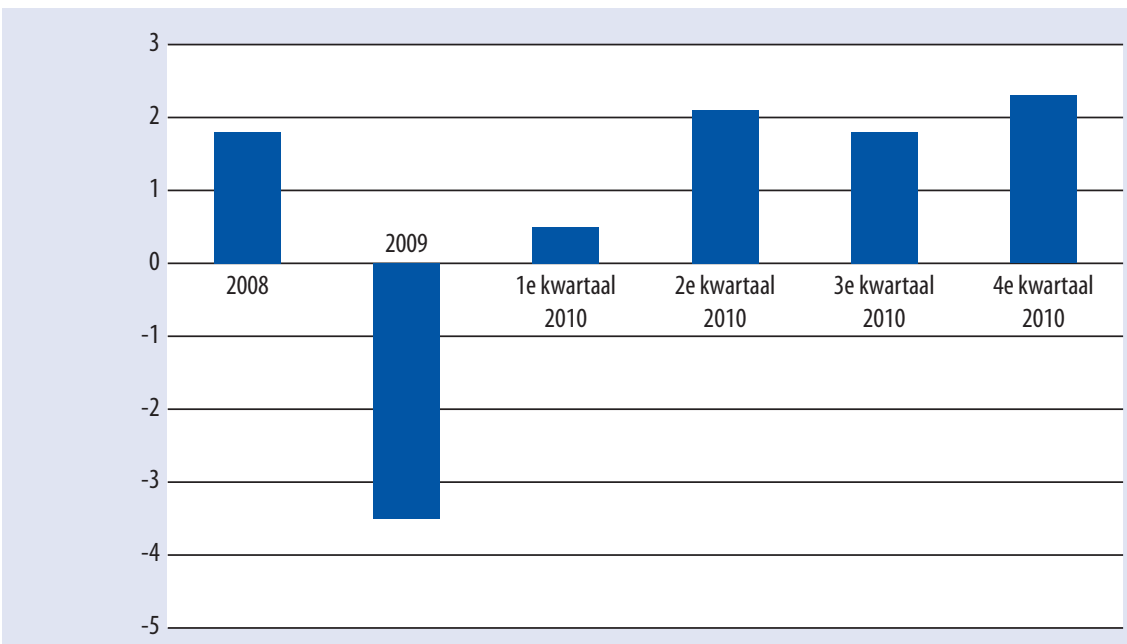

Bron: CBS, Statline, 4-7-2011

Tabel 1.7

Intredewerkloosheid van ten minste 1 maand (\%)

\begin{tabular}{|rrrrrrrrrr|} 
& BOL 1 & BBL 1 & BOL 2 & BBL2 & BOL 3 & BBL3 & BOL 4 & BBL 4 & HB0 \\
\hline Voorjaar 2008 & 28 & 3 & 12 & 3 & 11 & 3 & 9 & 0 & 21 \\
\hline Voorjaar 2009 & 12 & 0 & 18 & 10 & 14 & 3 & 15 & 3 & 26
\end{tabular}

Zie ook Tabel 15 in de Statistische Bijlage

Van het cohort 2008-2009 was in het geheel $15 \%$ ten minste I maand werkloos direct na behalen van het diploma. Dit is zoals verwacht een duidelijke stijging tegenover het cohort 2007-2008 (II\% van hen was ten minste I maand werkloos). Opvallend genoeg is onder 
de gediplomeerden van het MBO niveau I de intredewerkloosheid gedaald. Deze daling zal een gevolg kunnen zijn van een succesvolle uitvoering van het School-Ex programma door de $\mathrm{MBO}$-scholen. Immers, eerder onderzoek (ROA, 20IO) heeft laten zien dat één op de vier gediplomeerden van het MBO-niveau I zich door de activiteiten in het kader van het School-Ex programma heeft laten beïnvloeden en alsnog verder is gaan leren (zie ook box I.2 van dit hoofdstuk). Deze sterke toename in doorstromers naar een vervolgopleiding heeft uiteraard het aanbod aan MBO-niveau I gediplomeerden op de arbeidsmarkt verlaagd. Hiertegenover staat dat we vooral bij de opleidingen op niveau 2 van het $\mathrm{MBO}$ zien dat in de zomer van 2009 de intrede op de arbeidsmarkt moeilijker is geworden. Was van het cohort 2007-2008 in de zomer van 2008 nog I2\% (BOL niveau 2), respectievelijk, 3\% (BBL niveau 2) ten minste een maand werkloos voordat ze hun eerste baan vonden, in de zomer van 2009 (cohort 2008-2009) was dit I8\%, respectievelijk, IO\%. Maar ook onder de afgestudeerden van het $\mathrm{HBO}$ naam de intredewerkloosheid toe (van $21 \%$ naar $26 \%) .{ }^{8}$

Box 1.3

Arbeidsmarkt voor de gediplomeerden van het VMBO

Slechts een klein deel van de rond 85.000 gediplomeerden van het VMBO (са. 2\%-3\%) biedt zich na het behalen van het VMBOdiploma aan op de arbeidsmarkt zonder tegelijkertijd een opleiding te zijn gaan volgen. Aangezien deze jongeren (in de regel in de leeftijd onder de 23 jaar) geen startkwalificatie (minimaal MBO diploma op niveau 2) bezitten dienen zij als voortijdige schoolverlaters gezien te worden. Niet verrassend gezien hun magere basis om te starten op de arbeidsmarkt kennen zij nogal een problematische transitie van onderwijs naar arbeidsmarkt:

- $\quad 34 \%$ is tussen diploma-uitreiking een eerste baan ten minste 1 maand werkloos geweest;

- $16 \%$ van hen is op moment van enquête (ongeveer anderhalf jaar na afstuderen) werkloos.

Maar ook indien zij werk vinden, kunnen er vragen bij de kwaliteit hiervan gesteld worden:

- $58 \%$ heeft geen vaste aanstelling;

- $\quad 9 \%$ is werkzaam als uitzend-/oproepkracht;

- $48 \%$ werkt maximaal 32 uur per week;

- $10 \%$ is werkzaam in een functie die maximaal basisonderwijs vereist;

- $70 \%$ verdient minder dan Euro 1.000 bruto per maand.

Ondanks dat, zijn ze redelijk tot zeer tevreden met hun functie:

- $58 \%$ is (zeer) tevreden met hun huidige functie;

- $62 \%$ denkt dat de huidige functie (heel veel) carrièremogelijkheden biedt.

Deze tevredenheid ten spijt zal deze groep (voortijdig) schoolverlaters op langere termijn een moeizame loopbaan op de arbeidsmarkt tegemoet gaan indien ze niet op een later tijdstip alsnog een startkwalificatie halen.

Op moment van enquête (najaar 20I0) was $5.6 \%$ van de gediplomeerden van het $\mathrm{MBO}$ en $6 \%$ van de afgestudeerden van het $\mathrm{HBO}$ werkloos. In vergelijking met meting 2009 bleef de werkloosheid onder de $\mathrm{HBO}$ afgestudeerden daarmee constant terwijl de werkloosheid onder de gediplomeerden van het MBO zelfs licht daalde. Figuur I.I6 laat zien dat de economische crisis van 2009 blijkbaar minder negatieve gevolgen voor de gediplomeerde schoolverlaters

8. De gemiddeld hogere intredewerkloosheid onder de gediplomeerden van het HBO komt deels doordat zij een langere en uitgebreidere zoektocht hebben naar een 'perfecte' match tussen opleiding en werk. Met andere woorden, de gepresenteerde intredewerkloosheid is niet per definitie synoniem voor een onvrijwillige werkloosheid. 
van het $\mathrm{MBO}$ kende dan de in groeitermen minder sterke maar langere crisis van de jaren $200 \mathrm{I}$ tot 2005. Steeg de werkloosheid onder de gediplomeerden van het MBO in de jaren 200 I tot 2005 van gemiddeld zo'n $2 \%$ tot bijna I $2 \%$, in de crisis van 2009 en de nasleep daarvan in 2010 bleef de werkloosheid op $6 \%$ steken.

Dat de werkloosheid sterk afhankelijk is van het gevolgde opleidingsniveau komt in tabel I.8 duidelijk tot uiting. De tabel laat per opleidingsniveau en waar mogelijk per opleidingssector binnen een opleidingsniveau de werkloosheid op moment van enquêtering (najaar 20Io) zien. Ter vergelijking wordt ook het werkloosheidcijfer uit meting 2009 (cohort 2007-2008) gepresenteerd.

\section{Figuur 1.16}

Werkloosheid onder recent gediplomeerden van het MBO en het $\mathrm{HBO}(\%)$

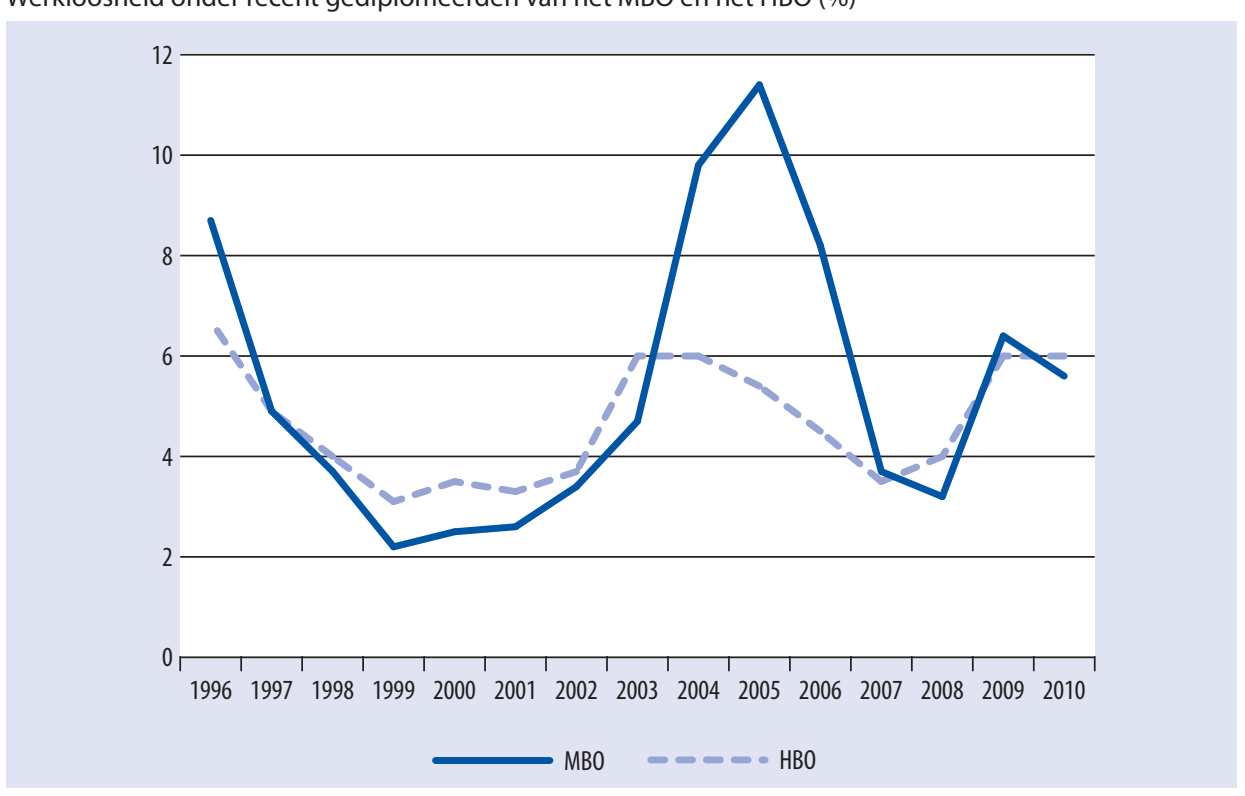

Bron: SIS (ROA), 1996-2010

Met $25 \%$ is de werkloosheid onder de gediplomeerden van het MBO-BOL niveau I met afstand het hoogst. Onder hun collega's van het MBO-BBL niveau I is de werkloosheid weliswaar aanzienlijk lager (7\%) maar ook zij kennen binnen hun leerweg duidelijk de hoogste werkloosheid. De cijfers voor de $\mathrm{MBO}$ niveau I gediplomeerden bevestigen dan ook nog een keer het belang van een 'startkwalificatie', dat wil zeggen een diploma op minimaal niveau 2, voor een succesvolle intrede op de arbeidsmarkt. De werkloosheid onder de gediplomeerden van niveau 2 steeg zowel bij degenen die een BOL diploma hebben behaald als bij degenen die een BBL diploma hebben behaald met 2\%-punt. In 20 Io was daarmee respectievelijk I4\% en $5 \%$ van hen werkloos. Onder de gediplomeerden van het MBO-BOL niveau 2 verbeterde zich de arbeidsmarktsituatie tegenover 2009 alleen voor de gediplomeerden van de sectoren Landbouw (van I8\% naar I2\%) en Gezondheidszorg (van I5\% naar I4\%). Terwijl zich de situatie eveneens voor de BBL niveau 2 gediplomeerden van de sector Landbouw verbeterde 
(werkloosheid daalde van $3 \%$ naar o\%), verslechterde zich de situatie voor de gediplomeerden van de $\mathrm{MBO}-\mathrm{BBL}$ niveau 2 sector Gezondheidszorg (van o\% naar 6\%).

De werkloosheidscijfers voor de gediplomeerden van het MBO-niveau 3 laten zien dat zij, vergelijkbaar met de gediplomeerden van niveau I, van het economisch herstel in 2010 konden profiteren. Zo daalde de werkloosheid onder recent gediplomeerden van het MBO-BOL niveau 3 van II\% (meting 2009) naar 5\% (meting 2010) en onder de gediplomeerden van het $\mathrm{MBO}-\mathrm{BBL}$ niveau 3 van $3 \%$ naar $2 \%$. In beide leerwegen zijn het op dit niveau vooral de gediplomeerden van de sector Economie die in 2010 nog aanzienlijk last van de economische crisis ondervonden. Daarnaast kennen de gediplomeerden van de MBO-BOL niveau 3 sector techniek met $7 \%$ een licht bovengemiddelde werkloosheid. De ondervraagde gediplomeerden van de technische opleidingen in het MBO-BBL hadden daarentegen geen moeite bij het vinden van een baan. Dit geldt ook voor de gediplomeerden van de sector Gezondheidszorg (BOL en BBL), de sector Landbouw (BBL) en de sector Gedrag \& Maatschappij (BBL).

Tabel 1.8

Werkloosheid op enquêtemoment (\%)

\begin{tabular}{|c|c|c|c|c|c|c|c|c|c|}
\hline & BOL 1 & BOL 2 & BOL 3 & BOL 4 & BBL 1 & $\mathrm{BBL} 2$ & BBL 3 & BBL 4 & HBO \\
\hline Landbouw & & 12 & 4 & 9 & & 0 & 1 & 0 & 6 \\
\hline Onderwijs & & & & & & & & & 5 \\
\hline Techniek & & 17 & 7 & 8 & & 4 & 0 & 0 & 5 \\
\hline Economie & & 13 & 10 & 8 & & 7 & 6 & 6 & 8 \\
\hline Gezondheidszorg & & 14 & 1 & 1 & & 6 & 1 & 1 & 3 \\
\hline Gedrag \& Maatschappij & & & 5 & 6 & & & 0 & 2 & 7 \\
\hline Taal \& Cultuur & & & & & & & & & 6 \\
\hline Totaal 2010 & 25 & 14 & 5 & 6 & 7 & 5 & 2 & 2 & 6 \\
\hline Totaal 2009 & 30 & 12 & 11 & 6 & 9 & 3 & 3 & 1 & 6 \\
\hline
\end{tabular}

Zie ook Tabel 14 in de Statistische Bijlage

Daalde de werkloosheid onder de MBO-gediplomeerden van niveau 3, de werkloosheid onder de gediplomeerden van niveau 4 steeg vergelijkbaar met de werkloosheid onder de gediplomeerden van niveau 2 licht. Ook op dit niveau zijn het de gediplomeerden van de conjunctuurgevoelige sector Economie die een relatief hoge werkloosheid kennen: $8 \%$ van de MBO-BOL niveau 4 Economie gediplomeerden en $6 \%$ van de MBO-BBL niveau 4 Economie gediplomeerden was op moment van enquête werkloos. Opvallend is dat zich ook op dit niveau verder bij de meeste sectoren (de uitzondering is de sector Gezondheidszorg) een duidelijk verschil tussen de gediplomeerden van het BOL en de gediplomeerden van het BBL voordoet. Zo was $9 \%$ van de BOL-gediplomeerden van de sector Landbouw werkloos (BBL: ०\%), was de werkloosheid onder de gediplomeerden van de BOL sector Techniek 8\% (BBL: $0 \%$ ) en was $6 \%$ van de BOL-gediplomeerden van de sector Gedrag \& Maatschappij (BBL: $2 \%$ ) werkloos. De cijfers bevestigen dan ook nog een keer de algemeen duidelijk sterkere positie van de gediplomeerden van het MBO-BBL bij de intrede op de arbeidsmarkt tegenover de gediplomeerden van het MBO-BOL.

Bleef de totale werkloosheid onder de afgestudeerden van het $\mathrm{HBO}$ tussen de twee metingen (2009 en 20IO) constant op 6\%, bij de onderliggende onderwijssectoren zien we echter (lichte) 
veranderingen. In vergelijking met meting 2009 trad een lichte verslechtering op bij een viertal sectoren: Landbouw van $5 \%$ naar 6\%, Onderwijs van $3 \%$ naar $5 \%$, Gezondheidszorg van $2 \%$ naar $3 \%$ en Gedrag \& Maatschappij van $4 \%$ naar $7 \%$. De werkloosheid bleef bij een sector (Economie) constant. Deze sector kende aan het begin van de economische crisis (2009) een sterke stijging van $5 \%$ naar $8 \%$ werkloosheid. Tot slot zien we bij een tweetal sectoren (Techniek en Taal \& Cultuur) zelfs een daling van de werkloosheid. Terwijl de ontwikkelingen in de sector Techniek en in mindere mate Economie overeenkomen met het snelle herstel in deze sectoren op het moment dat de economie weer aantrekt, is de ontwikkeling in de sector Taal \& Cultuur nogal verrassend. Zeker gezien het feit dat de werkloosheid in deze sector voor het eerst sinds lange tijd weer op het gemiddelde niveau van het $\mathrm{HBO}$ uitkomt.

\begin{abstract}
Box 1.4
Etniciteit en kans op werk

Door middel van een logit analyse op de onderzoeksdata is gekeken welke factoren de kans op werk verhogen Uit deze analyses blijkt dat de kans op werk voor gediplomeerden/afgestudeerden van niet-westerse etniciteit aanzienlijk lager is. Opvallend is dat dit niet alleen voor de lagere opleidingsniveaus maar ook voor de afgestudeerden van het hbo geldt. Dit resultaat komt ook in rechtstreekse tellingen duidelijk naar voren. Zo is onder de afgestudeerden van het $\mathrm{HB} 0$ van niet-westerse afkomst $14 \%$ werkloos en is het onder de groep autochtone ex studiecollega's 5\%. Vergelijkbaar opvallende verschillen zien we binnen een aantal sectoren van het HBO. Zijn onder de groep niet-westerse allochtonen die een HBO diploma in de sector economie hebben behaald zo'n 18\% werklozen, onder de autochtone HBO economen is het iets minder dan 7\%. Vergelijkbare cijfers ( $12 \%$ versus $5 \%$ ) zien we ook onder de afgestudeerden van de sector HBO techniek en HBO Gedrag \& Maatschappij (14\% versus 6\%). Dat de economische crisis in 2009 de nadelige situatie van de HBO afgestudeerden met een niet-westerse achtergrond heeft versterkt wordt in onderstaande figuur zichtbaar. Echter, dezelfde figuur maakt ook aanschouwelijk dat in economisch goede tijden (bijvoorbeeld meetjaar 2007) de werkloosheid onder de niet-westerse allochtonen zo'n 2 keer zo hoog is dan de werkloosheid onder de autochtone afgestudeerden. In economische slechte jaren loopt dit verschil echter nog eens aanzienlijk op.
\end{abstract}

\title{
Figuur B.1
}

Werkloosheid onder afgestudeerden van het HBO naar etniciteit (\%), Bron: HBO-Monitor 2003-2010

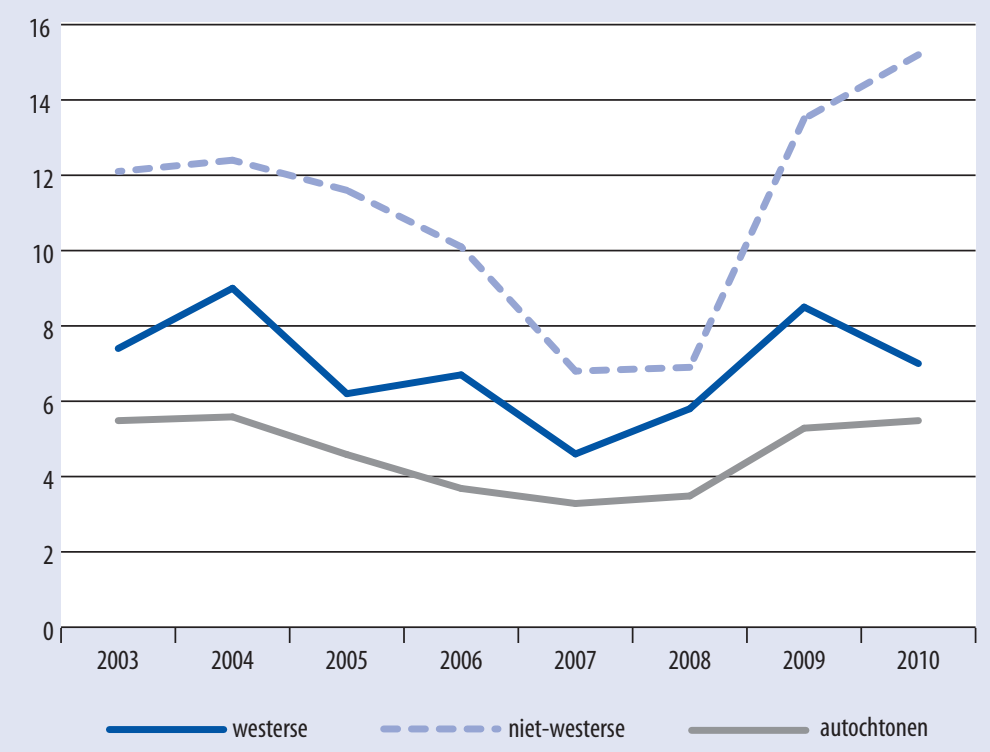




\subsection{Arbeidsmarkt: Werkorganisatie en dienstverband}

In deze paragraaf gaan we in op de bedrijven waar de jongeren werken, hun aanstelling (flexibel, deeltijd) en de aard van hun dienstverband. Om te beginnen laat figuur I.I7 het percentage van de werkende schoolverlaters zien dat in bedrijven met minder dan Io werknemers (kleinbedrijf), in bedrijven met ro tot en met 99 werknemers (middenbedrijf) en in bedrijven met minimaal roo werknemers (grootbedrijf) werkzaam is. Van alle werkende schoolverlaters is anderhalf jaar na behalen van het diploma ruim één op de twee werkzaam in een grootbedrijf. Één op de drie werkt voor een middenbedrijf en zo'n I6\% werkt in een bedrijf waar minder dan Io mensen werken. Een nadere analyse van de data laat zien dat het kleinbedrijf met 2I\% werkgelegenheid onder de gediplomeerden van het MBO-BOL niveau 2 relatief het vaakst voorkomt. MBO-BBL niveau 4 gediplomeerden aan de andere kant vinden het minst vaak werk in het kleinbedrijf. Van hen is slechts $8 \%$ in het kleinbedrijf werkzaam.

Kijken we aan de andere kant van het spectrum naar de bedrijven met minimaal Ioo werknemers, dan zien we dat deze relatief gezien iets vaker als werkgever van MBO-BBL gediplomeerden voorkomen dan als werkgever van $\mathrm{MBO}-\mathrm{BOL}$ gediplomeerden: van de $\mathrm{BBL}$ gediplomeerden werkt $58 \%$ voor een grootbedrijf, bij de BOL gediplomeerden is dit $52 \%$. Echter, onder de gediplomeerden van het MBO-BBL niveau 4 is $70 \%$ werkzaam voor een grootbedrijf en onder de gediplomeerden van het MBO-BBL niveau $278 \%$. Ook de afgestudeerden van het $\mathrm{HBO}$ werken in meerderheid voor een grootbedrijf $(56 \%)$.

\section{Figuur 1.17}

Klein-, Midden- of Grootbedrijf (\%)

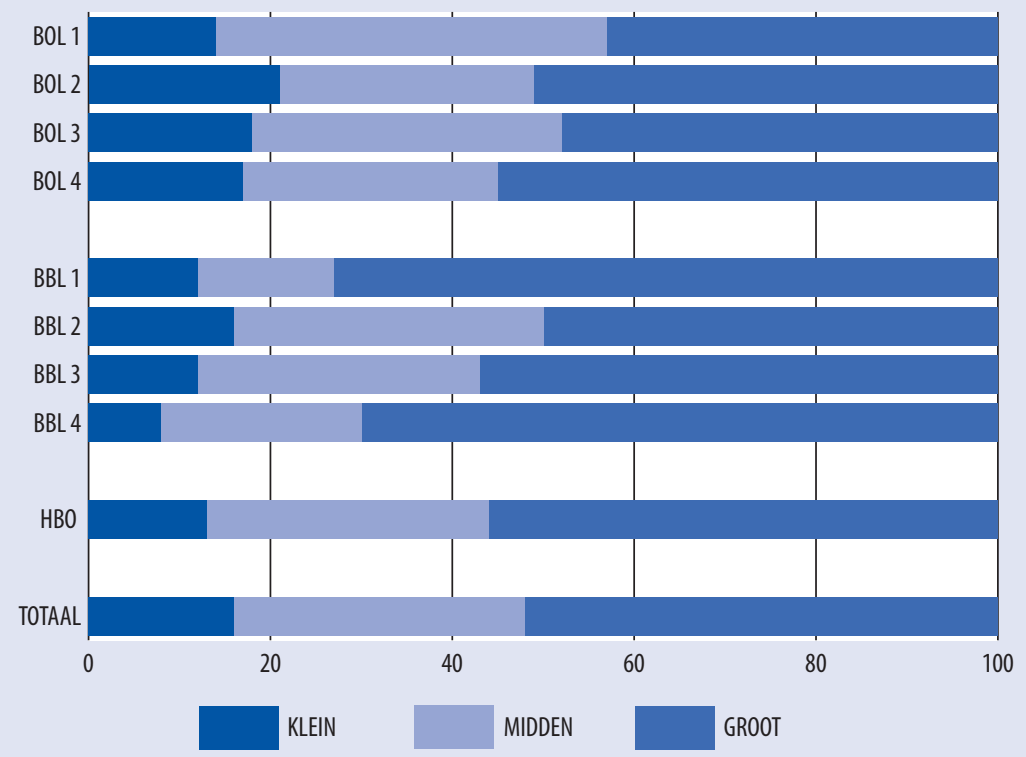

Kleinbedrijf: max 9 medewerkers; Middenbedrijf: 10 - 99 medewerkers, Grootbedrijf: > 99 medewerkers; Zie ook Tabel 16 in de Statistische Bijlage 
Behalve het al dan niet hebben van een betaalde baan zijn werkzekerheid en de omvang van de werkzaamheden twee belangrijke indicatoren voor het succes van de transitie tussen onderwijs en arbeidsmarkt. De twee kenmerken (flexibele en deeltijd aanstelling) die in tabel I.9 gepresenteerd worden geven hiervan een indicatie. Onder een flexibele aanstelling verstaan we een aanstelling als uitzendkracht, oproepkracht e.d. of een tijdelijke aanstelling. Van een deeltijdaanstelling is sprake wanneer iemand een aanstelling van 32 uur of minder per week heeft.

Er zijn nogal wat verschillen tussen de onderwijsniveaus ten aanzien van het aandeel van betaald werkende schoolverlaters met een flexibele aanstelling. Zo heeft van de werkende MBO-BOL niveau I uitstroom maar liefst 63\% een flexibele aanstelling. Maar ook onder de werkende uitstroom van de andere MBO-BOL niveaus is dit minimaal zo'n $50 \%$. Onder de werkende uitstroom van de MBO-BBL opleidingen is dit aanzienlijk minder. Zo heeft slechts één op de vijf werkende gediplomeerden van het MBO-BBL niveau I of 3 een flexibele aanstelling en is dit zelfs nog lager ( $15 \%)$ onder de werkende uitstroom van het MBO-BBL niveau 4. Onder de afgestudeerden van het $\mathrm{HBO}$ is het wederom zo'n 50\% dat een flexibele aanstelling bezit. Op alle onderscheiden niveaus zijn het in het algemeen de werkende gediplomeerden van de sectoren Techniek en Gezondheidszorg die relatief gezien minder vaak een flexibele aanstelling hebben.

\section{Tabel 1.9}

Flexibele aanstelling en deeltijd aanstelling (\%)

\begin{tabular}{lrrrrrrrrrr} 
& BOL 1 & BOL 2 & BOL 3 & BOL 4 & BBL 1 & BBL 2 & BBL 3 & BBL 4 & HB0 & Totaal \\
\hline Flexibele aanstelling & 63 & 53 & 49 & 50 & 20 & 35 & 21 & 15 & 51 & 43 \\
\hline Deeltijd aanstelling & 56 & 49 & 63 & 48 & 50 & 31 & 41 & 44 & 34 & 46 \\
Zie ook Tabellen 17 en 18 in de Statistische Bijlage & & & & & &
\end{tabular}

Natuurlijk mag hier niet direct de conclusie uit getrokken worden dat een relatief hoog percentage van gediplomeerde schoolverlaters met een flexibele aanstelling een teken van lage werkzekerheid is. Immers, onder de noemer van flexibele aanstelling vallen ook tijdelijke aanstellingen van bijvoorbeeld 2 of 3 jaren of traineeship-programmas waar relatief vaak afgestudeerden van het hoger onderwijs voor geselecteerd worden. Echter, het nadeel van een tijdelijke aanstelling is dat er in de regel al snel naar een andere baan gezocht dient te worden. Van de werkende gediplomeerden is op moment van enquête $15 \%$ op zoek naar een andere baan. Figuur I.I8 laat zien dat op onderwijssector niveau (bijvoorbeeld MBO-BOL niveau 2 Economie of HBO Landbouw) er een positieve relatie is tussen het percentage werkenden met een flexibele aanstelling en het percentage werkenden dat op zoek is naar ander betaald werk.

Onderzoek (Cörvers et al., 20Io) laat voor recent gediplomeerde schoolverlaters en afgestudeerden daarnaast een duidelijke relatie tussen het hebben van een flexibele aanstelling (uitzend-/oproepkracht dan wel contract voor bepaalde termijn) en minder gunstige arbeidsomstandigheden zien. Tabel I.Io vat de resultaten van dit onderzoek samen.

Recent gediplomeerde schoolverlaters die een flexibele aanstelling bezitten zijn vaker werkzaam buiten het eigen domein (horizontale mismatch), onder hun eigen schoolniveau (verticale mismatch) en in deeltijd werkzaam. Daarnaast worden ze minder vaak voor vervolgtraining geselecteerd en ligt hun salaris lager. Al deze factoren leiden dan ook ertoe dat zij minder 
tevreden met hun huidige functie zijn en dat ze vaker spijt hebben van de destijds gekozen opleiding.

Tabel I.9 laat ook het percentage werkenden met een deeltijdaanstelling zien. Van de werkende uitstroom van het $\mathrm{MBO}$ heeft bijna één op de twee een deeltijdaanstelling. Onder de gediplomeerden van het MBO-BOL is het gemiddeld net iets boven de $50 \%$ en onder de gediplomeerden van het MBO-BBL net iets onder de 50\%. Onder de afgestudeerden van het $\mathrm{HBO}$ is het aanzienlijk lager. Hier werkt slechts $34 \%$ in deeltijd. Kijken we nader naar de verschillende onderwijssectoren, dan komt in het algemeen een duidelijk beeld naar voren. De gediplomeerden van de sectoren Gezondheidszorg en Gedrag \& Maatschappij werken in de regel vaker in deeltijd en de gediplomeerden van de sector Techniek kennen het minst vaak een deeltijdaanstelling. Zo werkt van de werkende gediplomeerden van de MBO-BOL niveau 2 en 3 sector Gezondheidszorg minstens 80\% in deeltijd. Aan de andere kant werkt slechts één op de tien afgestudeerden van de $\mathrm{HBO}$-sector Techniek in deeltijd en is het percentage van de $\mathrm{MBO}$ gediplomeerden uit de sector Techniek dat in deeltijd werkt in de regel ook minder dan $20 \%$.

\section{Figuur 1.18}

Flexibele aanstelling versus zoeken naar betaald werk (\%)

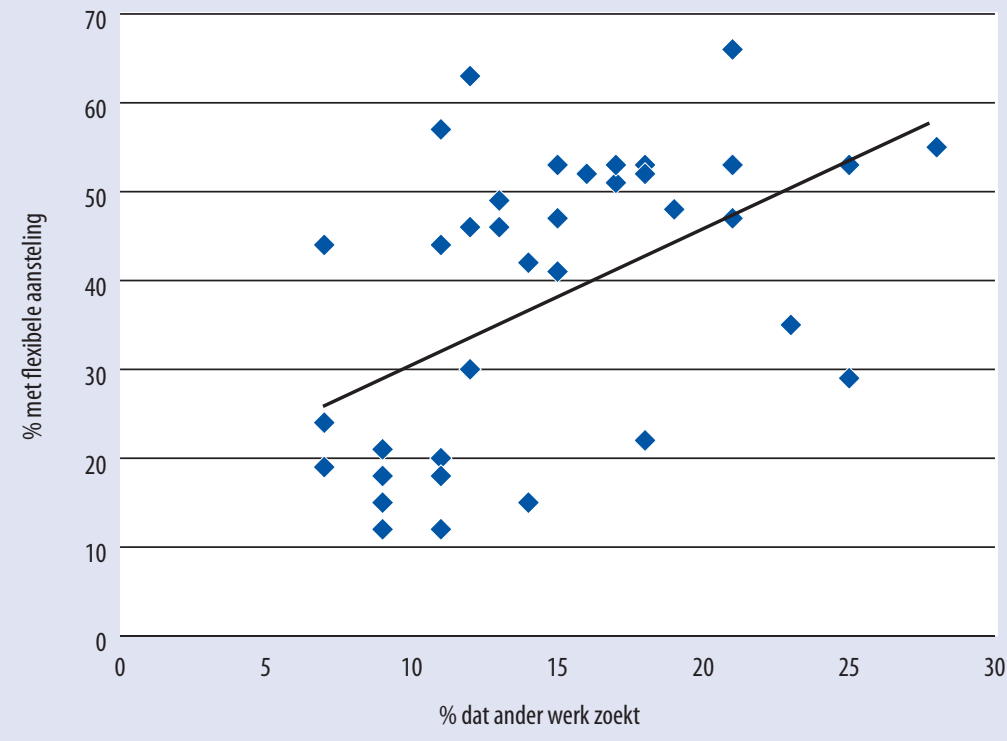


Tabel 1.10

Significante effecten van flexibele aanstelling op werksituatie (op basis van MBO-BOL en HBO gediplomeerden)

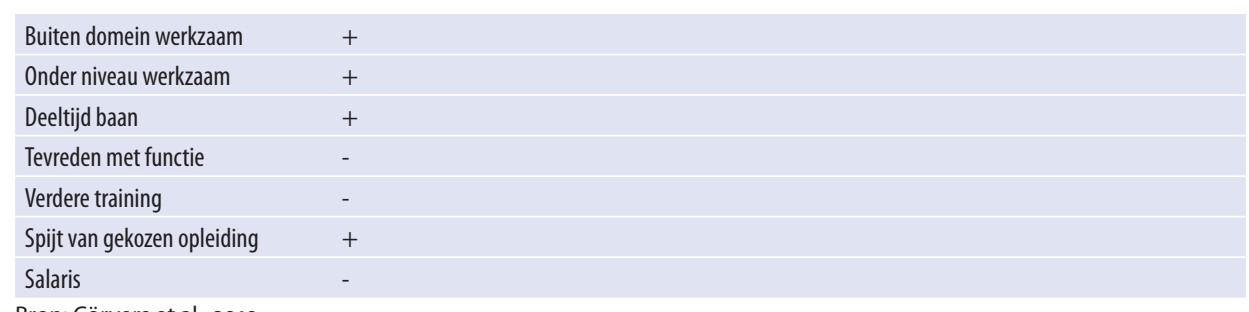

Bron: Cörvers et al., 2010

Eerder hebben we al gesteld dat de term 'flexibele aanstelling' een nogal heterogene groep van aanstellingen omvat. Om aan deze discussie verder bij te dragen staan we in het kort stil bij de aard van het dienstverband dat de jongeren op moment van enquêtering hebben. Op basis van de data kunnen er een vijftal types van dienstverbanden onderscheiden worden: a) leer/arbeidsovereenkomst, b) uitzend- of oproepkracht, c) loondienst, d) werkzaam in bedrijf van ouders en e) eigen bedrijf/freelancer. Omdat het percentage van de totale groep werkende gediplomeerden dat in het bedrijf van de ouders/partner werkzaam is minder dan $\mathrm{I} \%$ bedraagt en dat ook slechts $3 \%$ van de werkende gediplomeerden een eigen bedrijf heeft dan wel als freelancer werkzaam is, hebben we deze twee types van dienstverbanden in figuur I.I9 niet nader uitgesplitst. Hiermee willen we echter niet voorbij gaan aan het belang dat deze twee dienstverbanden hebben voor een aantal subgroepen van de gediplomeerde schoolverlaters. Zo werkt $7 \%$ van de MBO-BBL niveau 3 gediplomeerden van de sector Landbouw in het bedrijf van de ouders/partner en is dat onder de afgestudeerden van de HBO sector Landbouw ook $5 \%$. Op MBO niveau komt verder een eigen bedrijf (dan wel werkend te zijn als freelancer) wederom relatief vaak bij de gediplomeerden van de landbouwopleidingen voor. Zo geldt dit voor 9\% van de gediplomeerden van MBO-BOL niveau 4 landbouw en voor $5 \%$ van de gediplomeerden van deze sector op MBO-BOL niveau 3. Onder de afgestudeerden van het HBO bezitten de gediplomeerden van de sector Taal en Cultuur een uitzonderlijke positie. Van hen heeft maar liefst $64 \%$ een eigen bedrijf of is werkzaam als freelancer. Maar ook onder de afgestudeerden van de HBO sectoren Landbouw (8\%) en Gezondheidszorg $(7 \%)$ is het percentage zelfstandigen relatief hoog. 


\section{Figuur 1.19}

Aard van dienstverband (\%)

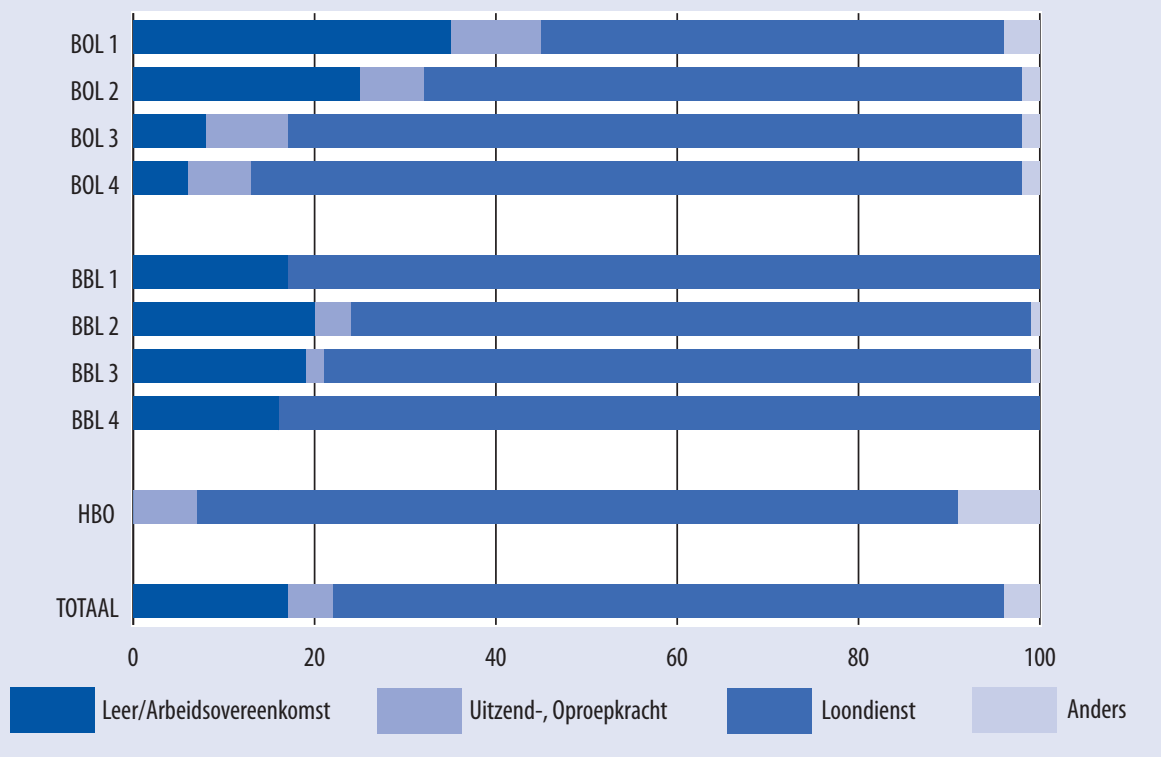

Zie ook Tabel 19 in de Statistische Bijlage

Het meest voorkomende dienstverband is echter zonder twijfel 'loondienst': $74 \%$ van de werkende gediplomeerden is in loondienst bij een werkgever. Een aanzienlijk kleiner deel ( $17 \%)$ is op het moment van de enquête in bezit van een leer/arbeidsovereenkomst en 'slechts' $5 \%$ is als uitzend-/oproepkracht werkzaam. Het laatste komt relatief gezien het vaakst onder de werkende uitstroom van het MBO-BOL niveau I voor. Van hen is $10 \%$ werkzaam als uitzend-/oproepkracht. Niet verrassend zijn het verder vooral de gediplomeerden van de lagere niveaus die relatief vaak een leer/arbeidsovereenkomst kennen (bijvoorbeeld in het kader van een opleiding die zij in het MBO-BBL volgen). Op de hogere niveaus speelt dit verder bij de gediplomeerden van het $\mathrm{MBO}-\mathrm{BBL}$ een relatief belangrijke rol. Hierbij gaat het om jongeren die een vervolg aan hun $\mathrm{MBO}-\mathrm{BBL}$ opleiding geven (gediplomeerden van het $\mathrm{MBO}-\mathrm{BBL}$ niveau 3) dan wel een duale opleiding in het $\mathrm{HBO}$ volgen (gediplomeerden van het MBO-BBL niveau 4).

\subsection{Arbeidsmarkt: Aansluiting tussen werk en opleiding}

Een belangrijke indicator voor de kwaliteit van het beroepsonderwijs is de mate waarin de gediplomeerden die zich op de arbeidsmarkt aanbieden passend werk vinden. De term passend werk kan op een tweetal dimensies betrekking hebben: horizontaal en verticaal. De horizontale dimensie betreft de vraag of de functie in welke men werkzaam is goed aansluit op de gevolgde onderwijssector wat richting betreft. De verticale dimensie heeft betrekking op de aansluiting tussen niveau van werk en niveau van gevolgde opleiding. Met andere woorden, de eerste dimensie betreft de vraag of de afgestudeerden van een technische opleiding ook inderdaad werk in een technisch beroep vinden en de tweede dimensie betreft de vraag of de afgestudeerden van het $\mathrm{HBO}$ werk vinden dat een $\mathrm{HBO}$-diploma vereist. Beide 
dimensies geven een indicatie van de benutting van het menselijk kapitaal. Onderbenutting zowel wat de horizontale match als wat de verticale match betreft heeft een aantal belangrijke consequenties. Zo stellen bijvoorbeeld Van de Werfhorst (2002) maar ook Heijke, Meng en Ris (2003) dat werknemers/schoolverlaters die in een beroep terecht komen dat qua richting niet aansluit bij de gevolgde opleiding significant minder verdienen. Hetzelfde geldt ook (zie bijvoorbeeld Meng, 2006) voor schoolverlaters die qua niveau onder het niveau van de gevolgde opleiding werk vinden. In het geval van een horizontale mismatch dient de schoolverlater aanzienlijk meer getraind te worden met alle kosten van dien. Werkgevers zullen dan ook ten minste gedeeltelijk deze kosten in de vorm van een salarisverlaging aan de werknemer doorberekenen. De gediplomeerde schoolverlaters die qua niveau in een functie terecht komen die onder het gevolgde opleidingsniveau ligt zullen verder met het probleem van "use it or loose it" geconfronteerd worden. Gezien hun aangeleerde vaardigheden niet, of ten minste op een duidelijk lager niveau noodzakelijk zijn om de functie uit te oefenen, zullen deze over tijd gaan slijten (zie bijvoorbeeld De Grip, Bosma, Willems en van Boxtel, 2008 en ROA, 20II) Verder kan een langdurig verblijf in een lager dan optimale functie een negatief signaal afgeven aan potentiële toekomstige werkgevers met het gevaar dat deze groep schoolverlaters qua carrièreontwikkeling achterblijft.

Gezien het belang van een goede match tussen opleiding en functie voor een goede start op de arbeidsmarkt gaan we in deze paragraaf in op een drietal indicatoren waar de genoemde match mee in kaart kan worden gebracht. Alle drie indicatoren zijn subjectieve methoden, dat wil zeggen dat de benutting van de opgedane kennis op basis van de eigen inschatting van de respondenten gemeten wordt (voor een uitgebreidere discussie van deze methoden en de voor- en nadelen hiervan zie, RWI, 2009). Tabel I.II laat per onderwijsniveau het percentage gediplomeerden zien dat a) volgens eigen inschatting in het eigen domein werkt, b) volgens eigen inschatting een functie heeft die qua niveau overeenkomt met het niveau van de gevolgde opleiding en c) de eigen kennis en vaardigheden voldoende kan benutten.

Tabel 1.11

Match tussen opleiding en functie (\%)

\begin{tabular}{|lrrrrrrrrr|} 
& BOL 1 & BOL 2 & BOL 3 & BOL 4 & BBL 1 & BBL 2 & BBL 3 & BBL 4 & HB0 \\
\hline Werk in eigen domein & 77 & 59 & 78 & 76 & 51 & 64 & 79 & 83 & 79 \\
\hline Werk op niveau & 79 & 74 & 78 & 87 & 44 & 69 & 68 & 84 & 79 \\
\hline Benutting van kennis & 54 & 65 & 70 & 67 & 63 & 62 & 71 & 75 & 63 \\
\hline
\end{tabular}

Zie ook Tabellen 20, 21 en 26 in de Statistische Bijlage

$73 \%$ van de werkende gediplomeerden van het $\mathrm{MBO}$ en het $\mathrm{HBO}$ is van mening dat hun functie qua richting goed aansluit bij de opleidingssector waarin zij het diploma hebben behaald. In combinatie met het resultaat dat $77 \%$ aangeeft dat de functie qua niveau goed aansluit op de gevolgde opleiding laat tabel I.II zien dat het onderwijs in de regel goed lijkt aan te sluiten bij de huidige arbeidsmarkt. De uitzonderingen zijn de opleidingen op MBO-BBL niveau I. Van de werkende gediplomeerden van deze opleidingen geeft slechts één op de twee aan in het eigen domein te werken en nog minder (44\%) geeft aan een functie op eigen niveau te hebben.

Duiken we dieper in de data dan komen er wat de match tussen opleiding en werk betreft echter nogal grote verschillen naar voren. Niet verrassend zijn het vooral de gediplomeerden van de sterk beroepsgerichte sector Gezondheidszorg en de sector Gedrag \& Maatschappij 
die het zowel op $\mathrm{MBO}$ als op $\mathrm{HBO}$ niveau uitstekend doen wat betreft het vinden van een passende functie. Dit geldt zeker voor de horizontale match (gemiddeld vindt tussen de $80 \%$ en $90 \%$ van hen een baan in het eigen domein) maar ook voor de verticale match. Zo vindt rond de $93 \%$ van de gediplomeerden van de sector Gezondheidszorg op BBL niveau 3 en 4 een functie die bij hun niveau past. Dit geldt ook voor de gediplomeerden van de sector Gezondheidszorg op MBO-BOL niveau 4 en bij de afgestudeerden van het $\mathrm{HBO}$ uit deze sector is dit nog steeds $82 \%$. Op HBO niveau zijn het verder de afgestudeerden van de sector Onderwijs die een uitstekende match kennen. Zo'n 95\% van hen vindt dat de gevonden functie goed qua niveau en richting bij de gevolgde opleiding past.

Ondanks dat de werkende gediplomeerden daarmee (heel) tevreden zijn wat de horizontale en de verticale match betreft, zien we in tabel I.II dat ze wat betreft de benutting van hun kennis en vaardigheden iets kritischer zijn. Gemiddeld vindt 'slechts' $64 \%$ dat ze hun kennis en vaardigheden voldoende kunnen benutten in hun huidige functie. Met andere woorden, een functie op niveau dan wel in het eigen domein dient niet I op I overeen te komen met een functie waarin de gediplomeerden hun opgedane kennis en vaardigheden voldoende kunnen benutten. Echter, nader onderzoek laat zien dat er vooral tussen werken in eigen domein en benutting van kennis en vaardigheden een relatief sterke positieve relatie is (zie ook Hoofdstuk 2).

Werkzaam zijn buiten het eigen vakgebied gaat in de regel vaker gepaard met werkzaam zijn onder het eigen niveau. Dit komt duidelijk in tabel I.I2 naar voren. Verreweg de meeste schoolverlaters die binnen hun vakdomein werkzaam zijn werken ook op hun opleidingsniveau. Indien de schoolverlater echter een functie buiten zijn eigen vakdomein aanvaardt, neemt de kans aanzienlijk toe dat deze functie ook beneden het gevolgde opleidingsniveau is. Zo vindt van de schoolverlaters die buiten het eigen vakgebied terecht komen slechts bij de gediplomeerden van MBO-BOL niveau I (66\%), MBO-BOL niveau 2 (54\%) en de afgestudeerden van het $\mathrm{HBO}(5 \mathrm{I} \%)$ een meerderheid een functie op minimaal eigen niveau. Bij de eerste groep gediplomeerden speelt daarbij het feit dat er weinig banen zijn waarvoor het vereiste opleidingsniveau nog lager is dan $\mathrm{MBO}$ niveau I.

Tabel 1.12

$\%$ werkzaam op minimaal eigen opleidingsniveau

\begin{tabular}{lrrrrrrrrr} 
& BOL 1 & BOL 2 & BOL 3 & BOL 4 & BBL 1 & BBL 2 & BBL 3 & BBL 4 & HBO \\
\hline Indien werkzaam in eigen domein & 82 & 89 & 86 & 93 & 63 & 81 & 75 & 89 & 85 \\
\hline Indien werkzaam buiten eigen domein & 66 & 54 & 47 & 38 & 44 & 35 & 44 & 40 & 51
\end{tabular}

Ter afsluiting van deze paragraaf bespreken we nog het algemene oordeel dat de werkende gediplomeerden geven over de aansluiting tussen hun gevolgde opleiding en de arbeidsmarkt (zie figuur I.20). Één op de drie werkende gediplomeerden vindt de aansluiting goed en nog eens $44 \%$ vindt deze voldoende. De goede aansluiting tussen opleiding en werk qua niveau en richting komt ook hier weer tot uitdrukking. Immers, in totaal vind $77 \%$ de aansluiting voldoende of goed. Kijken we naar de onderliggende opleidingsniveaus, dan zien we dat eventuele verschillen zich vooral voordoen bij de antwoordcategorieën 'voldoende' en 'goed'. Zo scoren de opleidingen op het laagste MBO-niveau (BOL en BBL niveau I) relatief gezien meer op de categorie 'goed' dan op de categorie 'voldoende'. Naarmate het opleidingsniveau toeneemt binnen het $\mathrm{MBO}$ is er een relatieve verschuiving richting de antwoordcategorie 'voldoende' in plaats van 'goed'. 


\section{Figuur 1.20}

Aansluiting tussen opleiding en werk

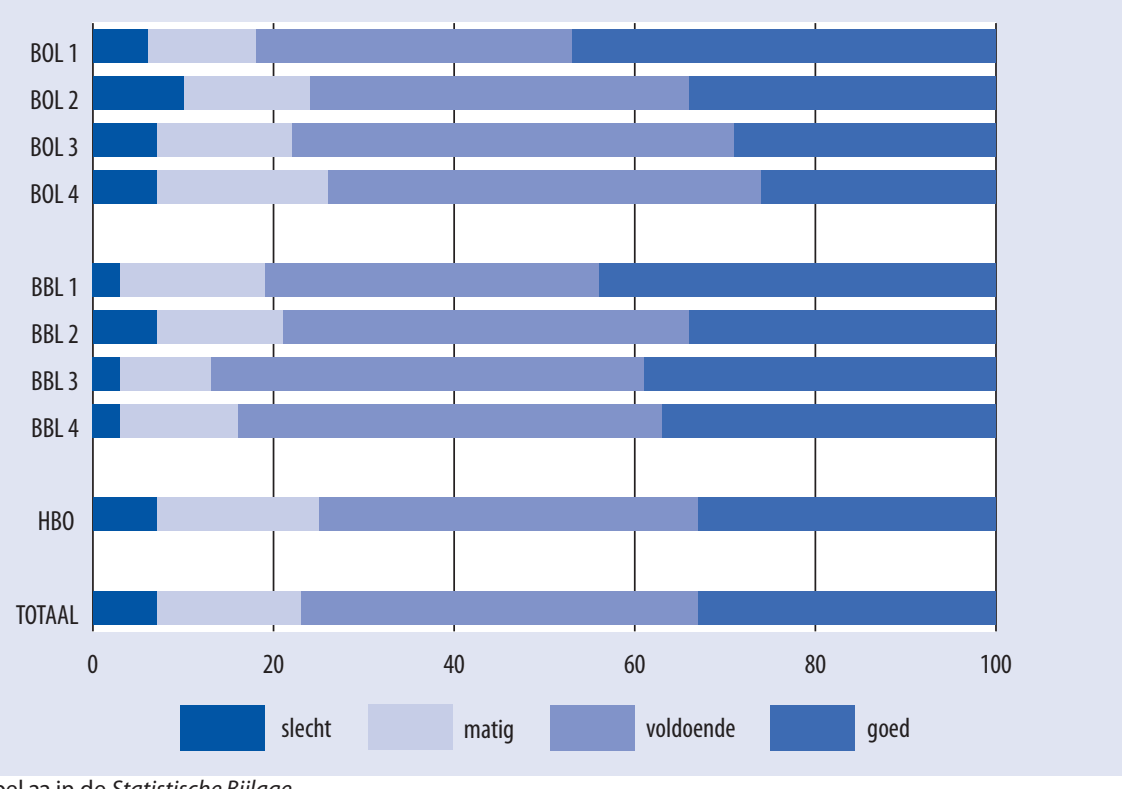

Zie ook Tabel 22 in de Statistische Bijlage

Tot slot staat in figuur I.2I het percentage werkende schoolverlaters aangegeven dat van mening is dat de aansluiting tussen de gevolgde opleiding en de functie goed of voldoende vindt samen met de andere in deze paragraaf besproken indicatoren. Uit deze figuur blijkt allereerst dat dit percentage over de verschillende onderwijsniveaus gezien redelijk stabiel is. Daarnaast toont de figuur dat dit oordeel maar in heel beperkte mate beïnvloed wordt door de andere indicatoren zoals onder andere het hebben van werk in de eigen richting en het hebben van werk op eigen niveau.

\section{Figuur 1.21}

Aansluiting opleiding en werk \% goed/voldoende in relatie tot functiekenmerken

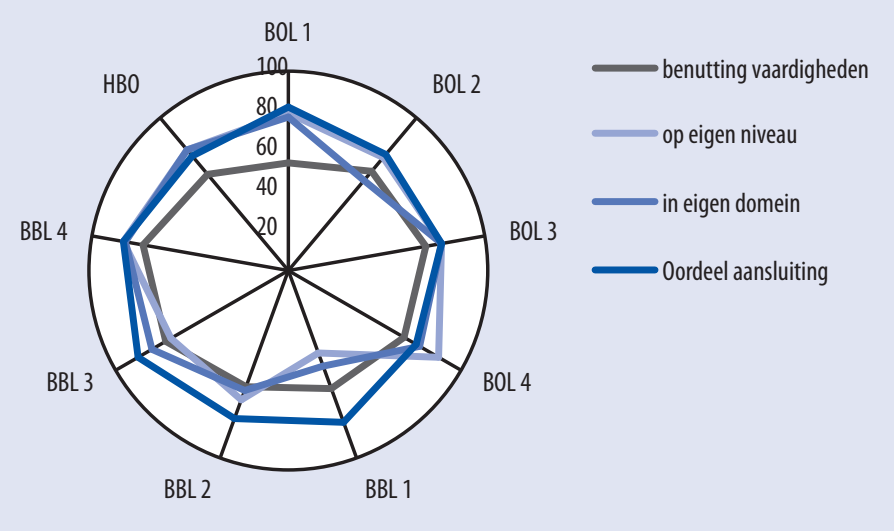




\subsection{Arbeidsmarkt: Salaris}

In economische termen een belangrijke indicator van het rendement van een opleiding op de arbeidsmarkt is zonder twijfel de beloning van de werkende gediplomeerden. In tabel I.I3 wordt zowel het gemiddeld bruto maandloon als het gemiddelde bruto uurloon gepresenteerd. Gezien het gemiddelde bruto maandloon sterk van het aantal werkuren afhankelijk is, bespreken we tegelijkertijd ook het gemiddeld aantal uren dat de gediplomeerden per week werkzaam zijn.

Het gemiddelde uurloon van de gediplomeerden van het MBO-BOL bedraagt Euro 9,70, dat van de gediplomeerden van het MBO-BBL Euro II,4O en dat van de afgestudeerden van het $\mathrm{HBO}$ Euro 13,55 . In vergelijking tot het meetjaar 2009 zijn startsalarissen daarbij tussen de I.2\% (HBO afgestudeerden) en zo'n 2.5\% (MBO-BBL afgestudeerden) gestegen. Ondanks dat voor alle drie type gediplomeerden de uurlonen tegenover 2009 licht gestegen zijn, heeft dit alleen in het geval van de MBO-BBL ook tot een lichte stijging in het maandloon geleid. Bij de afgestudeerden van het MBO-BOL en het $\mathrm{HBO}$ zijn door een lichte daling in het gemiddeld aantal uren dat ze per week werken de maandsalarissen niet gestegen.

Kijken we nader naar de verschillende onderwijsniveaus, dan zien we dat zowel binnen het $\mathrm{MBO}-\mathrm{BOL}$ als ook binnen het MBO-BBL het maandsalaris stijgt naarmate het onderwijsniveau toeneemt. Een vergelijkbaar beeld zien we ook bij de uurlonen. Daarnaast kunnen we vaststellen dat op alle niveaus de gediplomeerden van het MBO-BBL een aanzienlijk hoger maandsalaris dan wel uurloon kennen dan de MBO-BOL afgestudeerden. Een van de hoofdredenen hiervoor zal de uitgebreidere werkervaring van deze groep gediplomeerden en de daarmee gepaard gaande hogere leeftijd van de gediplomeerden van het MBO-BBL kunnen zijn. Immers, gemiddeld zijn de gediplomeerden van het MBO-BBL op moment van enquête bijna 9 jaar ouder dan hun studiecollega's die de opleiding in het MBO-BOL hebben gevolgd. Vooral de sector Gezondheidszorg kent in het MBO-BBL een grote groep gediplomeerden die de leeftijd van 30 gepasseerd is. Box 1.5 gaat kort in op het verschil tussen het salaris van de gediplomeerden van het $\mathrm{MBO}-\mathrm{BOL}$ en de gediplomeerden van het MBO-BBL.

Tabel 1.13

Bruto uurloon, bruto maandloon en aantal werkzame uren

\begin{tabular}{|lrrr|}
\hline & Uurloon & Maandloon & Aantal uren \\
\hline BOL 1 & 5,95 & 885 & 31.8 \\
\hline BOL 2 & 8,00 & 1.115 & 32.6 \\
\hline BOL 3 & 9,75 & 1.265 & 30.2 \\
\hline BOL 4 & 10,65 & 1.455 & 32.2 \\
\hline BBL 1 & 9,10 & 1.255 & 32.3 \\
\hline BBL 2 & 10,30 & 1.535 & 34.9 \\
\hline BBL 3 & 11,95 & 1.680 & 33.5 \\
\hline BBL 4 & 13,70 & 1.930 & 32.6 \\
\hline & & & 35.9 \\
\hline HB0 & 13,55 & 2.030 & \\
\hline Uurloon afgerond op 5 eurocent, Maandloon afgerond op 5 Euro; Zie ook Tabellen 18 en 23 in de Statistische Bijlage
\end{tabular}


Een opvallend resultaat is dat het gemiddelde uurloon van de werkende gediplomeerden van het MBO-BBL niveau 4 zelfs licht hoger is dan dat van de afgestudeerden van het HBO. Omdat de MBO-BBL gediplomeerden echter zo'n 3 uur per week minder werken komt het uiteindelijke bruto maandsalaris van de afgestudeerden van het $\mathrm{HBO}$ nog steeds hoger uit. Als kanttekening dient hierbij opgemerkt te worden dat het gemiddelde salaris van de afgestudeerden van het $\mathrm{HBO}$ naar beneden gedrukt wordt door een laag gemiddeld salaris bij de afgestudeerden van de sector Taal en Cultuur. Zij verdienen gemiddeld Euro 9,50 per uur. Echter, nadere analyses laten zien dat bij twee sectoren (Techniek en Gedrag \& Maatschappij) de gemiddelde uurlonen van de gediplomeerden van het MBO-BBL niveau 4 iets hoger liggen dan bij de afgestudeerden van het HBO.

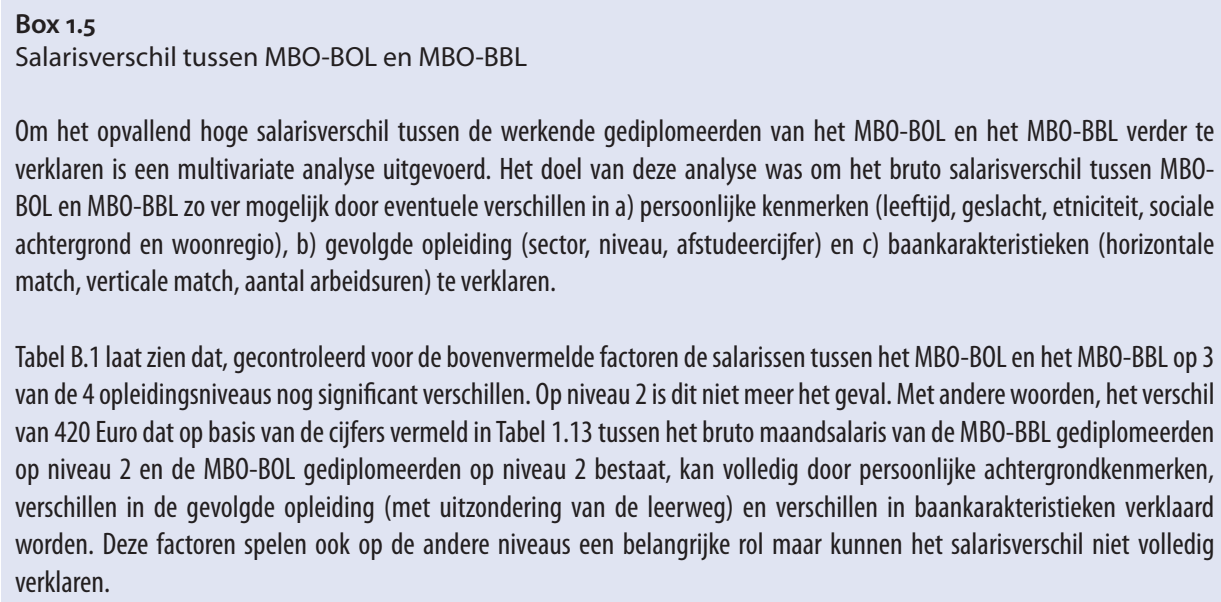
verklaren is een multivariate analyse uitgevoerd. Het doel van deze analyse was om het bruto salarisverschil tussen MBOBOL en MBO-BBL zo ver mogelijk door eventuele verschillen in a) persoonlijke kenmerken (leeftijd, geslacht, etniciteit, sociale achtergrond en woonregio), b) gevolgde opleiding (sector, niveau, afstudeercijfer) en c) baankarakteristieken (horizontale match, verticale match, aantal arbeidsuren) te verklaren.

Tabel B. 1 laat zien dat, gecontroleerd voor de bovenvermelde factoren de salarissen tussen het MBO-BOL en het MBO-BBL op 3 van de 4 opleidingsniveaus nog significant verschillen. Op niveau 2 is dit niet meer het geval. Met andere woorden, het verschil van 420 Euro dat op basis van de cijfers vermeld in Tabel 1.13 tussen het bruto maandsalaris van de MBO-BBL gediplomeerden op niveau 2 en de MBO-BOL gediplomeerden op niveau 2 bestaat, kan volledig door persoonlijke achtergrondkenmerken, verschillen in de gevolgde opleiding (met uitzondering van de leerweg) en verschillen in baankarakteristieken verklaard worden. Deze factoren spelen ook op de andere niveaus een belangrijke rol maar kunnen het salarisverschil niet volledig verklaren.

Tabel B.1

Salarisverschil in Euro tussen MBO-BBL en MBO-BOL

\begin{tabular}{|lrrrr} 
& Niveau 1 & Niveau 2 & Niveau 3 & Niveau 4 \\
\hline Bruto verschil & 370 & 420 & 415 & 475 \\
Resterend verschil & 191 & 0 & 88 & 160
\end{tabular}

Bron: BVE-Monitor 2010

Eerder in dit hoofdstuk is aan de orde geweest dat het succes van de transitie tussen onderwijs en arbeidsmarkt zich onder andere uit in de match tussen de gevolgde opleiding en het gevonden werk (zowel qua niveau als qua richting). De vraag is in hoeverre dit terug te vinden is in de salarissen van de recent gediplomeerde schoolverlaters. Een manier om hier inzicht in te krijgen is door regressieanalyses op de natuurlijke logaritme van de bruto uurlonen uit te voeren. Deze analyses laten zien dat een verticale match (functie past bij opleidingsniveau) zoals verwacht een aanzienlijk salarisvoordeel oplevert (voor de volledige resultaten van deze regressies zie bijlage I.I). Deze varieert tussen de $6 \%$ onder de gediplomeerden van het MBO-BBL en $15 \%$ onder de afgestudeerden van het $\mathrm{HBO}$. Voor de gediplomeerden van het MBO-BOL en de afgestudeerden van het $\mathrm{HBO}$ brengt een horizontale match (functie past bij opleidingsrichting) eveneens een significant salarisvoordeel met zich mee. Zo verdienen de gediplomeerden van het MBO-BOL die een functie binnen het eigen domein vinden zo'n $4 \%$ meer en de 
afgestudeerden van het HBO die binnen het eigen domein werkzaam zijn zelfs zo'n $6 \%$ meer dan hun studiecollega's die buiten het eigen domein werkzaam zijn.

Verder tonen de analyses dat mannelijke afgestudeerden een significant hoger uurloon kennen, dat het salaris met de leeftijd van de gediplomeerde/afgestudeerde toeneemt en dat in het $\mathrm{MBO}$ het salaris sterk afhankelijk is van het gevolgde onderwijsniveau. Daarnaast kennen de werkende gediplomeerden met een vaste aanstelling een hoger uurloon en leidt een voltijdbaan tot een lager uursalaris (ten minste onder de afgestudeerden van het $\mathrm{HBO}$ ).

\subsection{Tevredenheid: Werk en opleiding}

Tot slot van dit hoofdstuk staan we stil bij een aantal algemene oordelen omtrent de tevredenheid van de gediplomeerde schoolverlaters met hun werk en hun gevolgde opleiding.

\section{Tevredenheid met werk}

De tevredenheid met de huidige functie bespreken we aan de hand van een tweetal indicatoren: algemene tevredenheid en carrièreperspectieven (zie tabel I.I4 en figuur I.22). Dat de tevredenheid met de huidige functie van duidelijk meer aspecten afhankelijk is dan alleen van de carrièreperspectieven zien we in figuur I.22.

Gemiddeld is $69 \%$ van de werkende gediplomeerden tevreden met hun huidige functie en vindt ongeveer één op de twee dat de functie ook goede carrièreperspectieven biedt. Dat de gediplomeerden van de opleidingsniveaus I en 2 van het MBO ondanks hun vaak lagere werkzekerheid, salaris en carrièreperspectieven niet per definitie minder tevreden met het gevonden werk zijn, is zeker een van de belangrijkste conclusies die uit tabel I.I4 getrokken kan worden. Immers, ook van hen is een duidelijke meerderheid tevreden met het huidige werk en scoren ze wat dit aspect betreft niet per definitie lager dan de afgestudeerden van het HBO. Tevredenheid hangt dan ook met meerdere factoren samen en zeker ook met de verwachtingen die de jongeren kennen. De gemiddeld hoogste tevredenheid vinden we bij de gediplomeerden van de sector Gezondheidszorg. Bij hen is gemiddeld zo'n vier op de vijf tevreden met de huidige functie wat zeker met het feit zal samenhangen dat zij vaak een functie hebben gevonden die heel goed aansluit bij de gevolgde opleiding. 


\section{Figuur 1.22}

Tevredenheid versus Carrièreperspectieven per opleidingssector

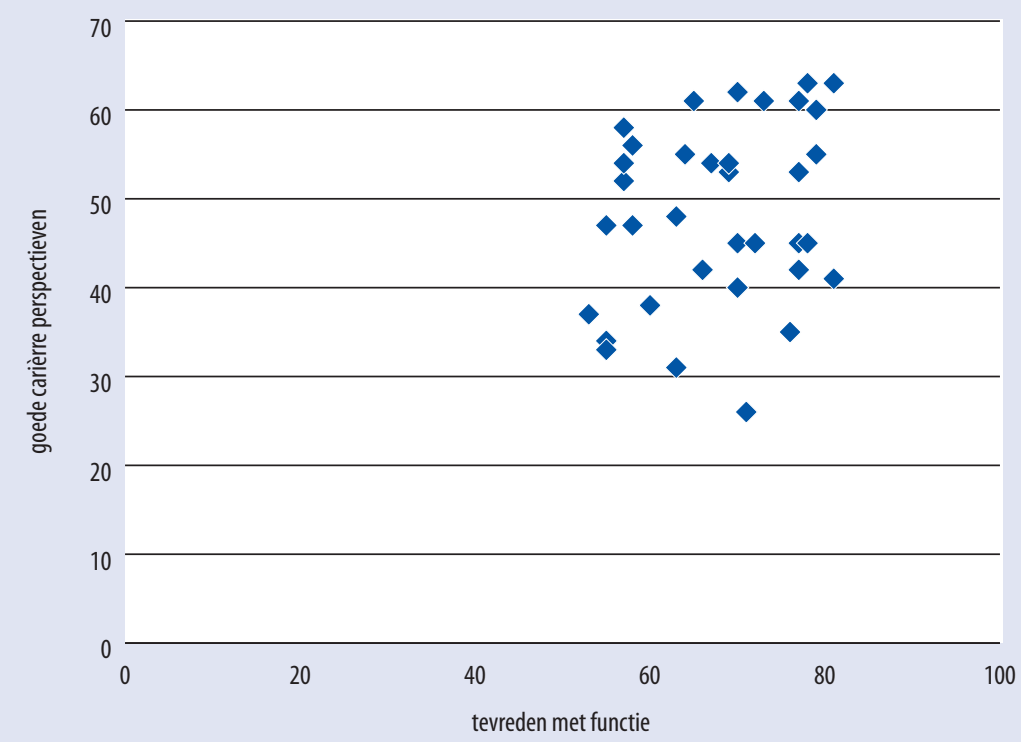

Tabel 1.14

Tevredenheid en carrièreperspectieven

\begin{tabular}{lrrrrrrrrrr|} 
& BOL 1 & BOL 2 & BOL 3 & BOL 4 & BBL 1 & BBL 2 & BBL 3 & BBL 4 & HBO & Totaal \\
\hline Tevreden met huidige functie & 63 & 68 & 71 & 70 & 55 & 63 & 68 & 73 & 65 & 69 \\
\hline Functie biedt goede carrièreperspectieven & 31 & 58 & 51 & 52 & 34 & 44 & 49 & 53 & 49 & 53
\end{tabular}

Zie ook Tabellen 24 en 25 in de Statistische Bijlage

Wat de vraag betreft of de huidige functie goede carrièreperspectieven biedt, laten de resultaten geen twijfel toe over de kansen van de laagst opgeleiden, de gediplomeerden van het MBO-niveau $\mathrm{r}$ : bij hen vindt slechts één op de drie dat de functie goede carrièreperspectieven biedt. Op niveau 2 is het al $44 \%$ (BBL) en zelfs $58 \%$ (BOL). De afgestudeerden van het $\mathrm{HBO}$ schatten de carrièreperspectieven niet direct hoger in dan de gediplomeerden van de hogere $\mathrm{MBO}$ niveaus. Onder hen zijn het bovendien de afgestudeerden van de sector Techniek (62\% denkt dat de functie goede carrièreperspectieven biedt) en de afgestudeerden van de sector Landbouw (6I\%) die op dit punt bovengemiddeld tevreden zijn. De laagste kans op goede carrièreperspectieven in de huidige functie zien de gediplomeerden van de HBO sector Onderwijs (26\%). Dit gebrek aan carrièreperspectieven is nog steeds een factor die in negatieve zin invloed heeft op de aantrekkelijkheid van banen in het onderwijs c.q. het lerarenberoep.

\section{Algemene tevredenheid met opleiding}

Tot zover hebben de analyses in dit hoofdstuk laten zien dat de gediplomeerde schoolverlaters van het Nederlandse onderwijssysteem in het algemeen tevreden zijn met de gevolgde opleiding en het gevonden werk. De uitzondering was het oordeel met betrekking tot de 
pittigheid van het examineren en de uitdagendheid van de gevolgde opleiding. De misschien meest cruciale vraag is dan ook of de jongeren achteraf gezien voor dezelfde opleiding zouden kiezen. De antwoorden op deze vraag laten nog een keer zien dat de jongeren zeer tevreden zijn: acht van de tien gediplomeerden zou achteraf bezien dezelfde opleiding kiezen. Hierbij doen zich geen duidelijke verschillen voor tussen de jongeren die zich (succesvol) op de arbeidsmarkt hebben aangeboden en de jongeren die voor een vervolg van hun onderwijscarrière hebben gekozen.

\section{Figuur 1.23}

Zelfde opleiding achteraf opnieuw kiezen

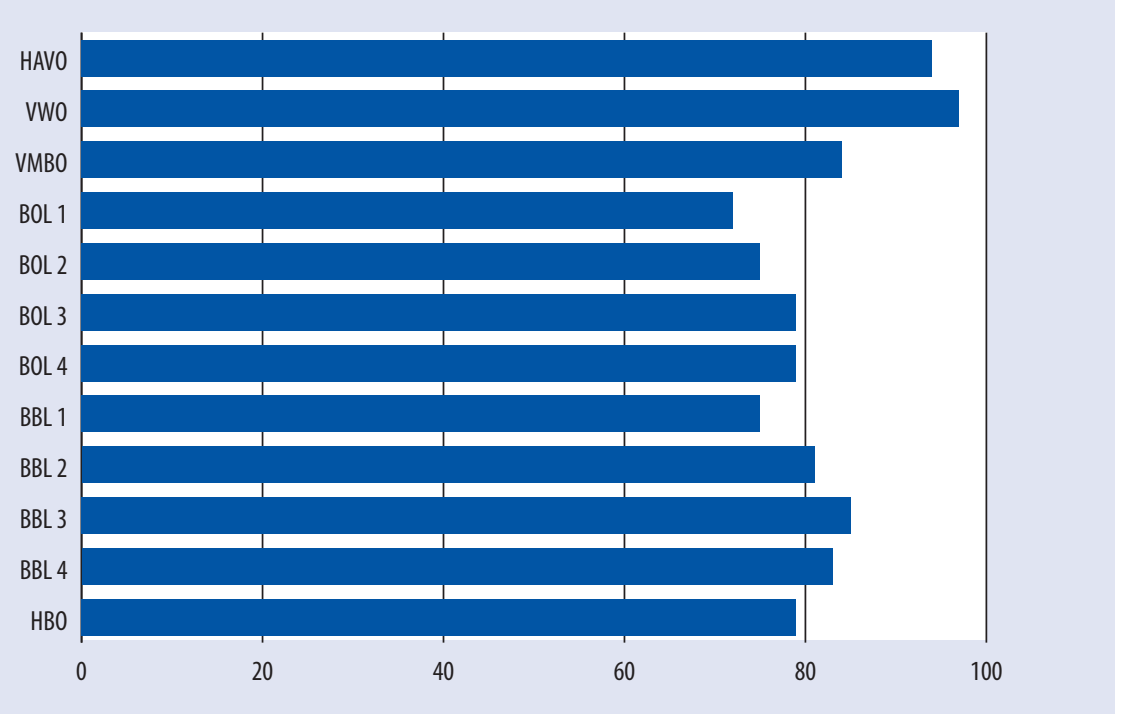

Zie ook Tabel 28 in de Statistische Bijlage

Figuur I.23 laat zien dat ook tussen de onderscheiden onderwijsniveaus geen grote verschillen te vinden zijn. Met uitzondering van de gediplomeerden van het MBO-BOL niveau I $(72 \%$ zou achteraf gezien dezelfde opleiding kiezen), geeft op alle onderwijsniveaus ten minste driekwart van de gediplomeerden aan dat ze dezelfde keuze zouden doen. Onder de gediplomeerden van het $\mathrm{VMBO}$ is het $84 \%$ (onder de jongeren die de theoretische leerweg dan wel de gemengde leerweg hebben gevolgd is het zelfs bijna 90\%). Vergelijkbaar hoge cijfers zien we ook bij de gediplomeerden van het MBO-BBL (niveau 2, 3 en 4). Zij zijn dan in de regel achteraf gezien ook iets meer tevreden dan de gediplomeerden van het MBO-BOL. Hier kan meespelen dat jongeren die het MBO-BBL volgen in de regel een pittigere selectie hebben doorgemaakt dan de jongeren die het $\mathrm{MBO}-\mathrm{BOL}$ volgen. Immers, om in het MBO-BBL in te stromen dient men een leerwerkplaats te bemachtigen wat inhoudt dat men een sollicitatieprocedure doorloopt. Jongeren die in het MBO-BBL hun opleiding volgen hebben dan ook minder vaak de gevolgen te dragen van een te snel en zonder voldoende informatie gemaakte studiekeuze. ${ }^{9}$

9. Het verschil in de manier van het maken van een studiekeuze tussen jongeren die in het $\mathrm{MBO}-\mathrm{BOL}$ instromen en jongeren die in het MBO-BBL instromen laat zich ook bij het voortijdige uitval uit de MBO-opleiding zien. We staan bij dit punt uitgebreider stil in hoofdstuk 2. 
HOOFDSTUK 1

De in Statistische Bijlage gepresenteerde cijfers per opleidingssector laten verder zien dat ook op het niveau van opleidingssectoren geen extreme verschillen te vinden zijn. 


\section{MBO-diploma in tijden van crisis: de waarde van studie- en beroepskeuzeadviezen}

\subsection{Inleiding}

$\mathrm{Na}$ een daling van drie jaar begon het werkloosheidscijfer door de economische crisis eind 2008 te stijgen in de landen van de Europese Unie. De werkloosheid kende in 2009 een toenemende groei voordat deze zich begin 2010 stabiliseerde. Sindsdien is er weer een lichte verbetering opgetreden. Het werkloosheidscijfer steeg in de 27 landen van de Europese Unie van $7 \%$ (2008) naar zo'n $9 \%$ in 2009 en zelfs bijna IO\% in 2010 . Deze algemene ontwikkeling van de werkloosheid in de afgelopen twee jaren was ook terug te zien in Nederland, maar dan op een aanzienlijk lager niveau (zie Figuur 2.I). Was in 2008 nog iets minder dan $4 \%$ werkloos, in 2009 was de werkloosheid in Nederland al gestegen naar 4,8\%. In het eerste kwartaal van 2010 werd een piek van $6 \%$ bereikt. De economische crisis heeft het herstel op de arbeidsmarkt na de eerdere economische malaise (200I/2002 tot 2005) dan ook teniet gedaan.

\section{Figuur 2.1}

Werkloosheidscijfer: Nederland (\%)

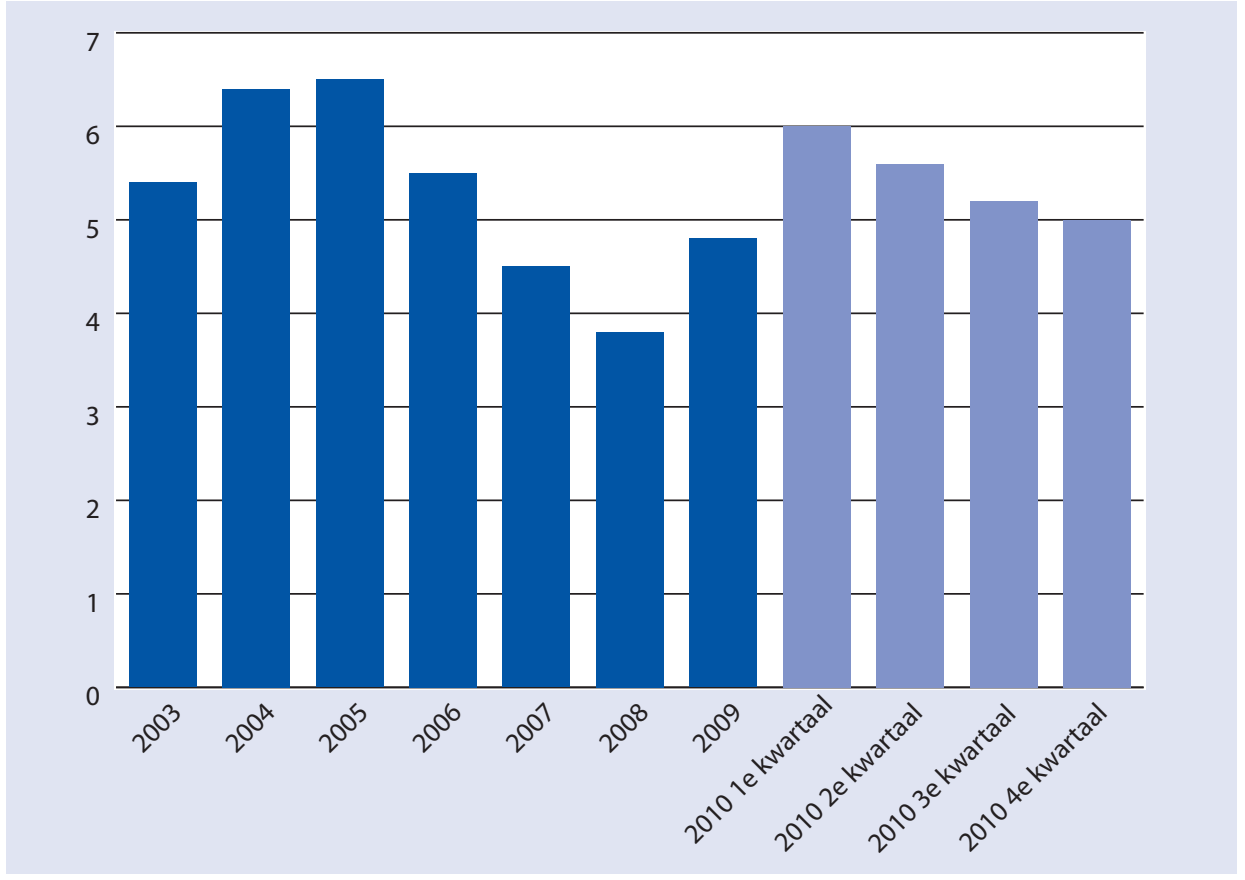

Bron: CBS: Statline 
De economische crisis beïnvloedde de arbeidsmarkt in alle landen van de Europese Unie, raakte zowel jong als oud, maar liet vooral de kwetsbaarheid van jongeren zien:

- Jongeren die nog geen gevestigde plaats op de arbeidsmarkt hebben verworven en die als eerste worden ontslagen indien het bedrijf waarvoor zij werken het moeilijk krijgt en

- Recent gediplomeerde schoolverlaters die moeilijk aan hun eerste baan kunnen komen.

De Nederlandse jeugdwerkloosheid (zie Figuur 2.2) steeg dan ook van 8,4\% naar II,7\% tussen 2008 en 2010 . Dit betekent een stijging van 3,3\%-punt. De algemene werkloosheid steeg in dezelfde periode met 2,2\%-punt. Ook hier geldt dat in vergelijking met de algemene werkloosheid in de Europese Unie de Nederlandse situatie nog steeds uitzonderlijk goed is. Zo was in 2010 meer dan $20 \%$ van de Europese jeugd werkloos en was dit in Spanje zelfs bijna één op de twee jongeren.

Figuur 2.2

Jeugdwerkloosheid: Nederland en EU27

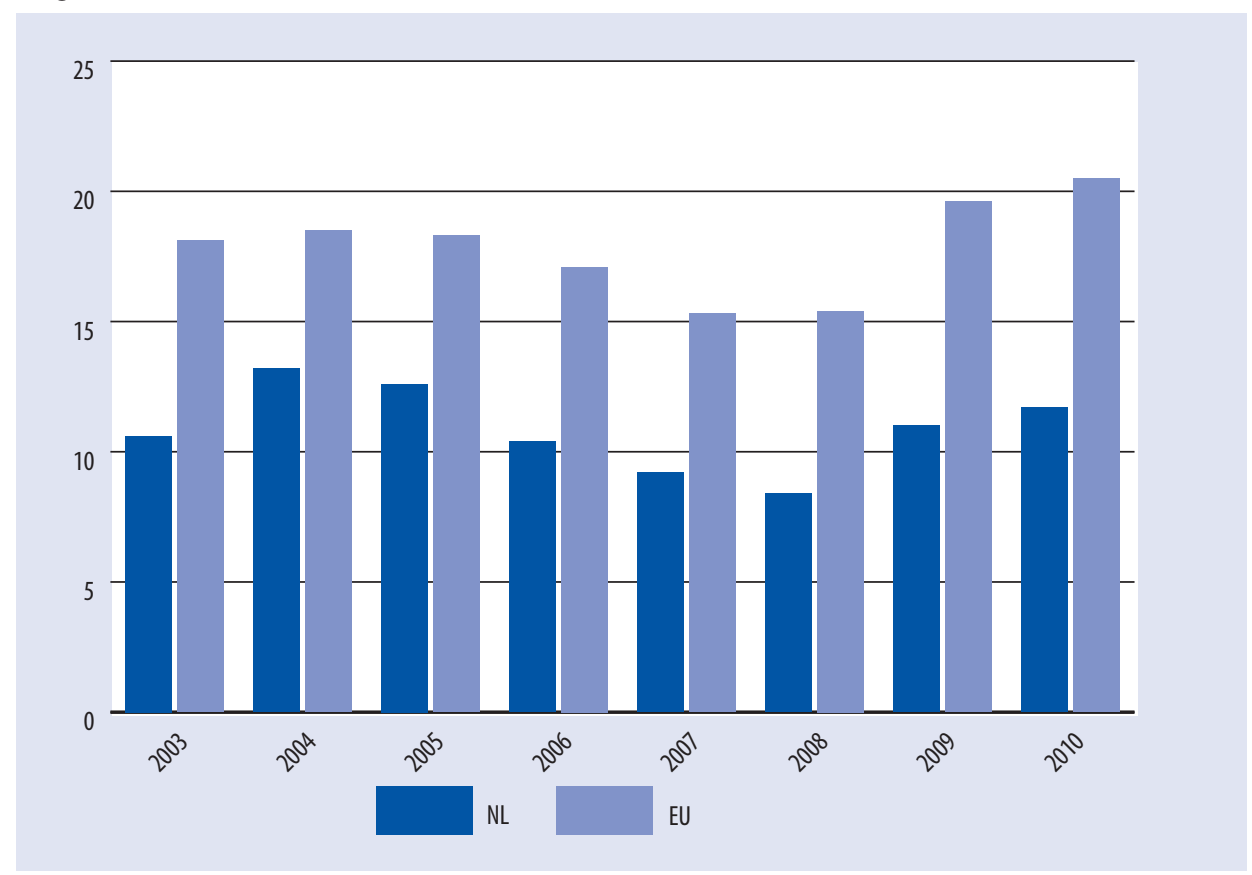

Bron: CBS (Statline) en Eurostat

Eerder onderzoek (zie ROA, 2009b) heeft al aangetoond dat het effect van de jeugdwerkloosheid in het jaar van afstuderen op de kans op werkloosheid positief en significant is: wie de arbeidsmarkt betreedt in een periode van hoge werkloosheid loopt een verhoogd risico op werkloosheid later in de loopbaan. Dit geldt vooral voor de gediplomeerden van lagere opleidingsniveaus (VMBO en lagere MBO-niveaus).

Gelet op de economische ontwikkelingen in de jaren 2009 en 2010 (zie figuur 2.3) stond het middelbare beroepsonderwijs (MBO) in Nederland dan ook voor een belangrijke taak. Jongeren die in deze jaren hun diploma ontvingen dienden er zoveel mogelijk van overtuigd te 
worden zich nog niet op de arbeidsmarkt aan te bieden, maar hun competenties eerst verder te ontwikkelen in het vervolgonderwijs. Een vervolg van de onderwijscarrière diende de jongeren niet alleen een stevigere basis te bieden om te starten op de arbeidsmarkt ${ }^{10}$, met op lange termijn betere carrièremogelijkheden, maar diende vooral ook de druk op de al zwaar belaste arbeidsmarkt te verlichten.

In dit hoofdstuk gaan we nader in op de problemen die de gediplomeerden van het MBO in de twee crisisjaren tegenkwamen. We doen dit door te kijken naar zowel kwantitatieve als kwalitatieve effecten van persoonlijke studiekeuzeadviezen alsook beroepskeuzeadviezen. We stellen ondermeer de vraag of scholen in staat zijn om jongeren te beïnvloeden in hun keuze om zich aan te bieden op de arbeidsmarkt of een vervolg te geven aan hun onderwijscarrière. We vragen of studiekeuzeadviezen tot een hoger rendement in het vervolgonderwijs kunnen leiden en of beroepskeuzeadviezen in tijden van economische malaise de overgang van onderwijs naar arbeidsmarkt kunnen versoepelen.

\section{Figuur 2.3}

Werkloosheid onder recent gediplomeerden van het MBO

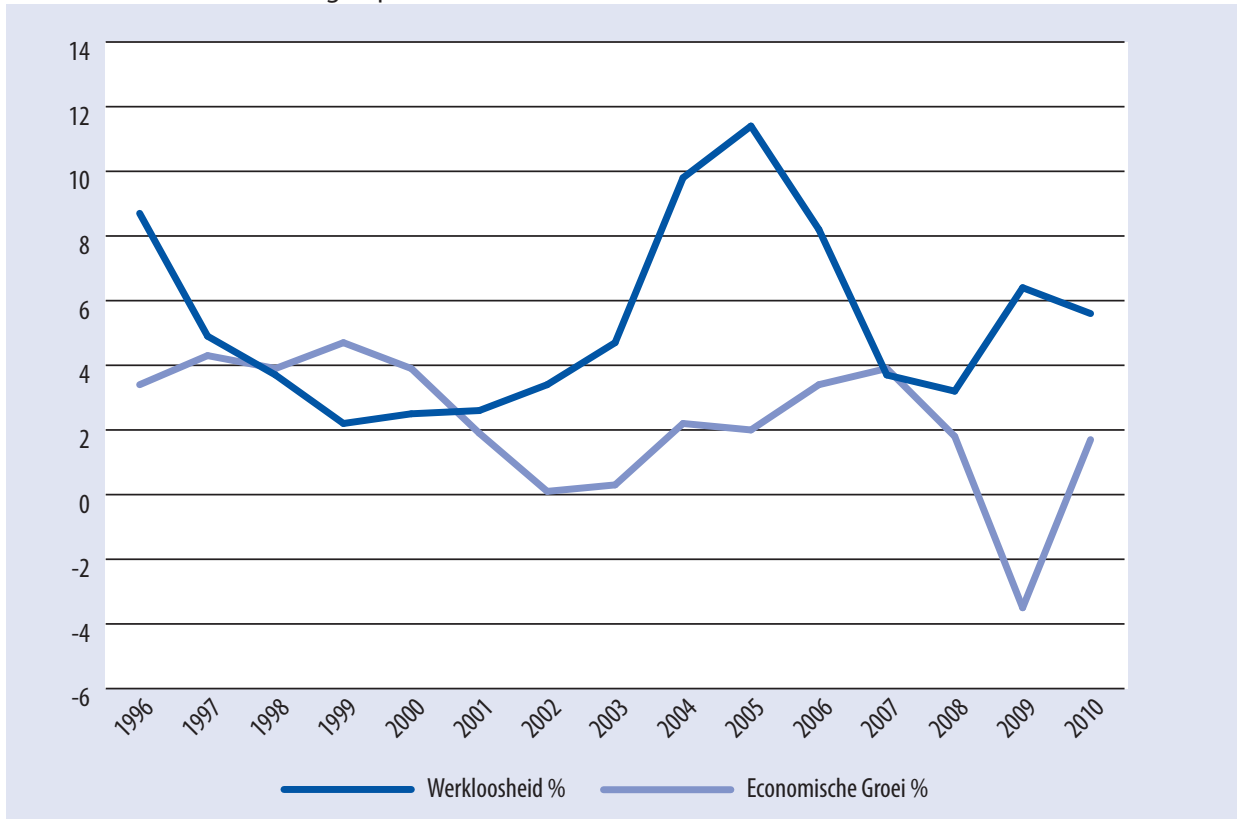

Bron: SIS (BVE-Monitor) 1996-2010; CBS statline

Het hoofdstuk heeft daarmee een tweeledig doel. Aan de ene kant biedt het een algemene discussie van de mogelijke effecten die studiekeuzeadviezen en beroepskeuzeadviezen in tijden van economische crisis teweeg kunnen brengen. Aan de andere kant biedt het hoofdstuk een bijdrage aan een evaluatie van het School-Ex Programma (zie paragraaf 2.3). Het uiteindelijke doel van een evaluatie dient zonder twijfel breder te zijn. De bredere vraag moet zijn of het programma inderdaad de groei van de jeugdwerkloosheid heeft kunnen beperken. Deze vraag

Io. In de regel geldt dat met toenemend onderwijsniveau de kans op werk stijgt (zie Hoofdstuk I). 
valt echter buiten de scoop van dit hoofdstuk. Ondanks deze kanttekening geeft Figuur 2.3 enig inzicht in deze bredere scoop.

Op het moment van bevraging (najaar 20I0) van de gediplomeerden van het MBO (schooljaar 2008-2009) was namelijk 'slechts' 5,6\% werkloos. In vergelijking met de bevraging in 2009 (gediplomeerden van het schooljaar 2008-2009) was dit zelfs een lichte daling. Figuur 2.3 laat verder zien dat de economische crisis van 2009 blijkbaar minder negatieve gevolgen voor de gediplomeerden van het MBO kende dan de in groeitermen minder sterke maar langere crisis van de jaren $200 \mathrm{I}$ tot 2005 . Steeg de werkloosheid onder de gediplomeerden van het MBO in de jaren 200 I tot 2005 van gemiddeld zo'n $2 \%$ tot bijna $12 \%$, in de crisis van 2009 en de nasleep daarvan in 20 Io bleef de werkloosheid op 6\% steken.

Zoals eerder vermeld is de vraag wat de precieze bijdrage van het School-Ex Programma op deze relatief goede uitkomst is buiten de scoop van dit hoofdstuk. We zullen ons dan ook vooral richten op de vraag in hoeverre studiekeuzeadviezen en beroepskeuzeadviezen hier impliciet ondersteuning aan hebben kunnen bieden, zonder deze effecten precies te becijferen.

De opbouw van het hoofdstuk is als volgt. Paragraaf 2 biedt een korte verantwoording van de data die voor de analyses in dit hoofdstuk zijn gebruikt. Paragraaf 3 gaat dieper in op de studiekeuzeadviezen en de beroepskeuzeadviezen die aan jongeren zijn geboden. We analyseren daarbij de kans dat een jongere een dergelijk advies heeft gekregen. Paragraaf 4 gaat in op de vraag of studiekeuzeadviezen inderdaad tot de gewenste effecten hebben geleid, namelijk een hogere doorstroom naar het vervolgonderwijs zonder een verlaging van het rendement in het vervolgonderwijs. Paragraaf 5 staat stil bij de vraag of de door de MBO-scholen geboden beroepskeuzeadviezen de transitie tussen onderwijs en arbeidsmarkt daadwerkelijk versoepelen. Paragraaf 6 vat ten slotte de kernresultaten samen en stelt de vraag of het School-Ex Programma op dit onderdeel inderdaad succesvol was.

\subsection{Data}

Een analyse van de effecten van studie- en beroepskeuzeadviezen in het $\mathrm{MBO}$ op het succes van gediplomeerden in de gekozen vervolgopleiding dan wel op de arbeidsmarkt dient gebaseerd te zijn op betrouwbare data. Het voorliggende hoofdstuk maakt gebruik van een drietal databronnen afkomstig van drie enquêtes onder gediplomeerden van het $\mathrm{MBO}$.

\section{Quickscan metingen 2009 en 2010}

In het najaar van 2009 en 2010 is twee keer een enquête gehouden onder de gediplomeerden van het MBO. In 2009 betrof het de gediplomeerden van het schooljaar 2008-2009. Deze gediplomeerde MBO'ers werden dus zo'n half jaar na het behalen van het diploma bevraagd. In 2010 betrof het de gediplomeerden van het schooljaar 2009-20Io en dus wederom gediplomeerde MBO'ers die gemiddeld een half jaar na het behalen van het diploma zijn bevraagd. De meting van 2009 bevat informatie over de eerste groep gediplomeerden van het MBO die tijdens het School-Ex Programma hun diploma hebben behaald. De meting van 2010 omvat de jongeren die in het tweede jaar van het School-Ex Programma hun diploma hebben behaald. 
In beide Quickscan metingen (2009 en 20IO) zijn 20.000 gediplomeerden van het MBO benaderd om aan de internetenquête deel te nemen. In totaal hebben bijna 7.000 van hen aan de enquête deelgenomen. De voor de analyses gebruikte data vormen een betrouwbaar en landelijk representatieve databron over het eerste half jaar na het behalen van het diploma.

De Quickscan metingen geven ons de mogelijkheid om te analyseren:

a. welke jongeren aan het einde van hun opleiding een persoonlijk gesprek met een medewerker van de school hadden en daarin een studie- dan wel beroepskeuzeadvies kregen;

b. in hoeverre de studie- en beroepskeuzeadviezen de keuze tussen het aanbieden op de arbeidsmarkt en het vervolgen van de onderwijscarrière hebben beïnvloed;

c. in hoeverre deze keuze ook door andere activiteiten van scholen is beïnvloed;

d. met welke intentie de jongeren, die door de scholen zijn beïnvloed, met hun vervolgopleiding zijn gestart. Dat wil zeggen de vraag of deze jongeren een vervolgopleiding als tussenpauze zien die ze zo kort mogelijk willen houden.

De Quickscan metingen die circa een half jaar na het behalen van het diploma zijn gehouden, geven echter niet de mogelijkheid om het succes in de vervolgopleiding dan wel het succes op de arbeidsmarkt nader te analyseren. Hiervoor maken we gebruik van een tweede databron.

\section{BVE-Monitor 2010}

In het kader van het reguliere SchoolverlatersInformatieSysteem (SIS) is in het najaar van 20 Io een meting gehouden onder gediplomeerden van het MBO (schooljaar 2008-2009). De enquête onder deze groep jongeren vond gemiddeld anderhalf jaar na het behalen van het diploma plaats. In totaal zijn in deze meting zo'n 28.000 gediplomeerden van de verschillende MBO-niveaus aangeschreven. Uiteindelijk hebben bijna 7.000 gediplomeerde MBO'ers aan de enquête deelgenomen. De gebruikte data vormen een betrouwbare en landelijk representatieve databron over de eerste anderhalf jaar na het behalen van het MBO-diploma. De BVE-Monitor gegevens zijn eerder al uitgebreid gebruikt bij de beschrijvende analyses in hoofdstuk I

De BVE-Monitor geeft ons de volgende aanvullende mogelijkheden met betrekking tot het analyseren van de effecten van de studie- en beroepskeuzeadviezen:

a. analyseren van het succes van de gediplomeerden die doorgestroomd zijn naar een vervolgopleiding;

b. analyseren van de aansluiting tussen de gekozen vervolgopleiding en de gevolgde opleiding;

c. analyseren van de kans op werk zowel tijdens het directe intredemoment als ook anderhalf jaar na afstuderen;

d. analyseren van de kwaliteit van het gevonden werk.

\subsection{School-Ex Programma}

Jongeren stimuleren om verder te gaan leren. Dit was het centrale onderdeel van het School-Ex Programma dat in het kader van het Actieplan Jeugdwerkloosheid in het voorjaar van 2009 van 
start is gegaan en een vervolg kende in 20Io. Het School-Ex Programma bestond in hoofdlijnen uit twee elementen, namelijk een registratie van de toekomstplannen van examenkandidaten (de zogenaamde 'mobiliteitsregistratie') en het bieden van (individuele) studiekeuzeadviezen.

Wat betreft de tweede peiler (studiekeuzeadviezen) hebben scholen een groot aantal mogelijkheden om jongeren te stimuleren om verder te gaan leren. Zo kan informatie gegeven worden door middel van brochures, de schoolwebsite of extra bijeenkomsten. Daarnaast kunnen georganiseerde bezoeken aan opendagen van bijvoorbeeld hogescholen een belangrijke rol spelen. Docenten spelen hierbij natuurlijk een centrale rol. Door hun directe contact met de jongeren zijn zij in staat om op eenvoudige wijze actuele informatie over de arbeidsmarktomstandigheden aan te bieden. Meer aandacht besteden aan de risico's die verbonden zijn aan het aanbieden op de arbeidsmarkt tijdens een recessie, kan jongeren ertoe bewegen om deze stap nog een keer goed te heroverwegen.

Algemene middelen zoals brochures zijn effectief om een brede en vaak heterogene groep jongeren te bereiken. Extra aandacht voor de arbeidsmarktsituatie tijdens de les vormt een eenvoudige toegang tot een homogenere groep jongeren die als gemeenschappelijke deler dezelfde opleiding volgen. Om binnen de laatstgenoemde groep de meest kwetsbare individuen van gerichte informatie te voorzien, dient men echter het persoonlijk gesprek aan te gaan. Studiekeuzeadviezen werden dan ook, voor zover mogelijk, aangeboden in direct persoonlijk contact met de examenkandidaten (klas, mentorgroep, loopbaangesprek, diploma-uitreiking). Door deze individuele aanpak kregen de studenten gerichte adviezen vanuit de school (het zogenaamd 'studiekeuzeadvies') en werden zij gemotiveerd om langer te leren.

Het MBO dient inderdaad ook een stevige basis te bieden voor de intrede op de arbeidsmarkt. Afhankelijk van de situatie van de jongeren werd door de school in het gesprek, naast mogelijke vervolgopleidingen, dan ook de nadruk gelegd op de arbeidsmarktkansen. Individuele gesprekken met jongeren over hun arbeidsmarktkansen kunnen daarbij twee motieven hebben:

a. Het achterliggende motief kan zijn dat men probeert de jongeren te overtuigen van de moeilijkheden die een intrede op de arbeidsmarkt tijdens een crisis met zich meebrengt. In dit geval wordt getracht de jongeren zodanig te beïnvloeden dat zij de keuze voor het starten op de arbeidsmarkt nog een keer heroverwegen en alsnog voor een vervolgopleiding kiezen. In dit geval dient het beroepskeuzegesprek natuurlijk opgevolgd te worden door een individueel studiekeuzeadvies.

b. Het achterliggende motief kan zijn de jongeren te ondersteunen bij de transitie tussen onderwijs en arbeidsmarkt, advies te bieden over mogelijke manieren van solliciteren of hen toegang te bieden tot het netwerk dat de school heeft opgebouwd met bedrijven.

Tabel 2.I presenteert de resultaten van twee multivariate analyses. In eerste instantie bespreken we de kans dat de jongere een persoonlijk gesprek had waarin een studiekeuzeadvies gegeven werd. In tweede instantie bespreken we de kans op een persoonlijk gesprek met daarin een beroepskeuzeadvies. ${ }^{\text {II }}$ In beide analyses wordt gecontroleerd voor een aantal persoonlijke

II. Voor een beschrijvend overzicht over de omvang wat deze adviezen betreft, zie ROA, 20 o. 
achtergrondkenmerken (geslacht, leeftijd, etniciteit), voor een aantal opleidingsgerelateerde factoren (opleidingsniveau, leerweg, opleidingssector en gemiddeld afstudeercijfer). Tot slot zijn in de analyses verschillende activiteiten opgenomen die scholen in het kader van het School-Ex Programma eventueel hebben uitgevoerd. Het gaat daarbij om:

- Brochures, website: De school heeft extra informatie verspreid via extra brochures of via de schoolwebsite over de actuele situatie op de arbeidsmarkt.

- Extra bijeenkomsten: De school heeft extra informatiebijeenkomsten georganiseerd om over de actuele arbeidsmarktsituatie te informeren.

- Extra aandacht door docenten: Docenten hebben extra aandacht besteed aan de actuele arbeidsmarktsituatie.

Tabel 2.1

Multivariate analyse voor de kans dat gesprek over studiekeuzeadvies dan wel gesprek over beroepskeuzeadvies heeft plaatsgevonden

\begin{tabular}{|c|c|c|}
\hline & Studiekeuzeadvies & Beroepskeuzeadvies \\
\hline Autochtoon & Referentie & Referentie \\
\hline \multicolumn{3}{|l|}{ Westerse Allochtoon } \\
\hline \multicolumn{3}{|l|}{ Niet-westerse Allochtoon } \\
\hline Leeftijd & $-0.016^{* * *}$ & $0.012^{* *}$ \\
\hline Geslacht: man & $-0.337^{* * *}$ & $-0.186^{*}$ \\
\hline Afstudeercijfer & $0.057^{*}$ & \\
\hline \multicolumn{3}{|l|}{ Leerweg: MBO-BOL } \\
\hline MB0-niveau (1-4) & $-0.379^{* * *}$ & $-0.170^{* * *}$ \\
\hline \multicolumn{3}{|l|}{ Opleidingssector } \\
\hline Gezondheidszorg & Referentie & Referentie \\
\hline \multicolumn{3}{|l|}{ Landbouw } \\
\hline Techniek & $-0.413^{* * *}$ & \\
\hline Economie & $-0.236^{* *}$ & $-0.272^{* *}$ \\
\hline Gedrag \& maatschappij & & $-0.242^{*}$ \\
\hline \multicolumn{3}{|l|}{ Activiteit door scholen } \\
\hline Brochures, website & $0.334^{* * *}$ & $0.177^{*}$ \\
\hline Extra bijeenkomsten & $0.380^{* * *}$ & $0.242^{* *}$ \\
\hline Extra aandacht door docenten & $0.393^{* * *}$ & $1.094^{* * *}$ \\
\hline Studiekeuzeadvies & $x$ & $1.701^{* * *}$ \\
\hline Beroepskeuzeadvies & $1.699 * * *$ & $x$ \\
\hline Meetjaar 2010 & $-0.436^{* * *}$ & $-0.429^{* * *}$ \\
\hline
\end{tabular}

Bron: Quickscan 2009; 2010; Alleen significante effecten zijn weergegeven. Voor de volledige resultaten zie Bijlage 2.1.

Kijken we in eerste instantie naar de persoonlijke achtergrondkenmerken, dan zien we dat mannen minder vaak een dergelijk gesprek hebben gevoerd dan vrouwen. Doordat we in de analyse ook voor de opleidingsgerelateerde factoren controleren, kan dit effect niet verklaard worden door de relatieve oververtegenwoordiging van mannen in bepaalde sectoren (bijvoorbeeld de sector techniek). Natuurlijk kan hier eventueel meespelen dat jongens minder geneigd zijn om met de school op individuele basis te spreken dan meisjes. Daarnaast laat 
een vooruitblik op onze arbeidsmarktanalyses in paragraaf 5 echter ook zien dat zij misschien minder behoefte aan zo'n gesprek hebben omdat zij doorgaans een hogere kans op werk hebben. Een tweede interessante uitkomst is dat de kans op een adviesgesprek over de studiekeuze afneemt naarmate de examenkandidaten ouder zijn, terwijl de kans op een gesprek waarin een beroepskeuzeadvies gegeven wordt dan juist toeneemt. Dit wordt gedeeltelijk verklaard doordat een toenemende leeftijd de kans verhoogt dat de examenkandidaat voorafgaand aan de opleiding al werkervaring heeft opgedaan en de kans groter is dan bij een jongere examenkandidaat dat hij de opleiding in het kader van zijn werkzaamheden heeft uitgevoerd. De kans dat dergelijke gediplomeerden dan ook voor een vervolgopleiding kiezen is a priori al lager.

Wat betreft de opleidingsgerelateerde factoren zien we dat jongeren met een hoger gemiddeld examencijfer (al is het slechts op een Io\%-significantieniveau) vaker een studiekeuzeadvies gehad hebben. Dit lijkt in eerste instantie vreemd omdat deze groep in het algemeen een betere positie heeft. Het kan hier echter ook een omgekeerde correlatie betreffen. Jongeren met hoge cijfers nemen vaker zelf het initiatief voor een dergelijk gesprek. Wat betreft het opleidingsniveau geldt dat hoe hoger het opleidingsniveau is, hoe kleiner de kans op een gesprek is in beide analyses. Met andere woorden, de meest kwetsbare jongeren (niveau I en 2) hebben meer kans op een studie- én beroepskeuzeadvies. Het feit dat het effect in de eerste analyse (studiekeuzeadvies) daarbij duidelijk groter is dan het effect in de tweede analyse (beroepskeuzeadvies) lijkt erop te wijzen dat men vooral heeft getracht deze jongeren in het onderwijs te houden.

Bij de opleidingsgerelateerde factoren laten de analyses nog twee interessante effecten zien. Zo hebben de examenkandidaten van de sectoren Techniek en Economie minder vaak een studiekeuzeadvies gekregen dan hun studiegenoten die een opleiding in de sector Gezondheidszorg hebben gevolgd. Dit is opvallend aangezien laatstgenoemde sector veel minder last had van de dalende economie dan de sectoren Techniek en Economie. Voor gediplomeerden van de sector Economie geldt bovendien dat deze groep jongeren ook minder vaak een beroepskeuzeadvies heeft gekregen. De gevonden uitkomst dient dan ook eerder als een negatieve verrassing gezien te worden. ${ }^{\text {I2 }}$

De resultaten met betrekking tot de andere activiteiten die door scholen zijn uitgevoerd laten zien dat in het algemeen geldt dat scholen een combinatie van individuele gesprekken met meer algemene activiteiten hebben uitgevoerd. Zeker de resultaten van de tweede analyse (beroepskeuzeadvies) laten zien dat docenten die extra aandacht aan de arbeidsmarktsituatie hebben besteed in de regel ook vaker een individueel gesprek met beroepskeuzeadvies hebben gevoerd. De centrale rol van de docenten in dit kader wordt dan ook nog een keer bevestigd. Het feit dat de kans op een individueel studiekeuzeadvies sterk gecorreleerd is met de kans op een individueel beroepskeuzeadvies laat verder zien dat een beroepskeuzeadvies in de regel inderdaad gepaard ging met een studiekeuzeadvies.

I2. Hierbij moet opgemerkt worden dat de sector Gezondheidszorg qua samenstelling van opleidingen aanzienlijk homogener is dan bijvoorbeeld de sector Economie. Het gepresenteerde gemiddelde effect zal dan ook in de sector Gezondheidszorg meer in lijn met het effect van de onderliggende opleidingen liggen dan in de sector Economie. 
Tot slot laten de analyses zien dat de kans op een studie- dan wel beroepskeuzeadvies in het examenjaar 2010 lager was dan in het examenjaar 2009. Hier kan meespelen dat de economische verwachtingen, en daaraan gekoppeld de kansen voor de jongeren bij een intrede op de arbeidsmarkt, in de zomer van 2010 al duidelijk rooskleuriger waren dan in de zomer van 2009.

\subsection{Succes van studiekeuzeadviezen}

Wat zijn de effecten van individuele studiekeuzeadviezen? Laten jongeren zich hierdoor beïnvloeden en stromen ze alsnog door naar een vervolgopleiding? En helpen studiekeuzeadviezen een betere aansluiting met de vervolgopleiding te bewerkstelligen? Deze en andere vragen staan centraal in deze paragraaf.

De uitkomsten van studiekeuzeadviezen kunnen op twee manieren gemeten worden: kwantitatief en kwalitatief. Kwantitatief moeten individuele gesprekken over mogelijke vervolgopleidingen ertoe leiden dat jongeren in hun keuze tussen enerzijds zich aanbieden op de arbeidsmarkt en anderzijds het vervolgen van de onderwijscarrière alsnog voor laatstgenoemde kiezen (korte termijn effect). Het starten met een vervolgopleiding kan echter niet als directe doelstelling gezien worden. Indien jongeren op korte termijn het vervolgonderwijs namelijk weer verlaten, doordat zij bijvoorbeeld een baan gevonden hebben, worden deze eerste positieve effecten snel teniet gedaan. Het langere termijn effect van de individuele studiekeuzeadviezen is dan ook een succesvol vervolg te geven aan de onderwijscarrière.

Kwalitatief kunnen individuele studiekeuzeadviezen ertoe leiden dat jongeren een betere keuze maken over de precieze invulling van hun vervolg in het onderwijs. De gekozen vervolgopleiding zal dan beter op de individuele capaciteiten van de jongeren aansluiten, wat leidt tot een hogere kans van slagen. De kwalitatieve effecten kunnen dan de kwantitatieve effecten verder ondersteunen.

De beschikbare data laten zowel een analyse van de kwantitatieve als de kwalitatieve uitkomsten toe.

\section{Kwantitatieve effecten}

Wat de kwantitatieve effecten betreft bespreken we een tweetal analyses. Allereerst wordt bekeken of de studiekeuzeadviezen die in individuele gesprekken gegeven worden jongeren inderdaad beïnvloeden om alsnog verder te gaan leren. Ten tweede kijken we of de kans dat jongeren die een individueel studiekeuzeadvies hebben gekregen anderhalf jaar later nog met de gekozen vervolgopleiding bezig zijn groter is dan voor jongeren die geen individueel studiekeuzeadvies hebben gekregen.

Tabel 2.2 presenteert de resultaten van een multivariate analyse voor de kans dat de jongere door een activiteit van de school is beïnvloed en alsnog verder is gaan leren. We doen dit afzonderlijk voor de gediplomeerden van het MBO-BOL en de gediplomeerden van het MBO-BBL.

Uit de tabel blijkt dat individuele gesprekken met studiekeuzeadviezen inderdaad het 
verwachte positieve kwantitatieve effect hebben. Dit geldt zowel voor de gediplomeerden van het MBO-BOL als de gediplomeerden van het MBO-BBL. In eerste instantie verrassend is dat individuele gesprekken over de beroepskeuze geen significante effect laten zien. Dit kan een indicatie zijn dat dit type gesprekken niet primair bedoeld is om jongeren alsnog in het onderwijs te houden maar eerder bedoeld zijn om de jongeren te ondersteunen bij de transitie van onderwijs naar arbeidsmarkt. Echter, het resultaat kan ook betekenen dat er een sterke correlatie is tussen studie- en beroepskeuzegesprekken. Dat dit inderdaad zo is, heeft de discussie in paragraaf 2.3 al laten zien. Nadere analyses laten dan ook zien dat gesprekken waarin met de jongeren zowel over de arbeidsmarktkansen als over mogelijke vervolgopleidingen wordt gesproken het meest effectief zijn. De invloed van een gesprek waarin slechts één van de twee onderwerpen aan bod komt is aanzienlijk lager. Verder is er geen significant verschil tussen gesprekken die vooral een studiekeuzeadvies bieden en gesprekken die vooral ingaan op de arbeidsmarktkansen. Beide opties zijn weliswaar minder effectief dan een combinatie hiervan maar nog steeds significant effectiever dan géén gesprek.

Tabel 2.2

Analyse op kans dat jongeren alsnog is verder gaan leren (Logit analyse)

\begin{tabular}{|c|c|c|}
\hline & MBO-BOL & MBO-BBL \\
\hline Autochtoon & Referentie & Referentie \\
\hline \multicolumn{3}{|l|}{ Westerse Allochtoon } \\
\hline Niet-westerse Allochtoon & $0.868^{* * *}$ & $0.622^{*}$ \\
\hline Leeftijd & $-0.063^{* * *}$ & $-0.054^{* * *}$ \\
\hline Geslacht: man & $0.344^{* * *}$ & \\
\hline Afstudeercijfer & $0.095^{* *}$ & $0.272^{* * *}$ \\
\hline MBO-niveau & $-0.268^{* * *}$ & $-0.650^{* * *}$ \\
\hline \multicolumn{3}{|l|}{ Opleidingssector } \\
\hline Gezondheidszorg & Referentie & Referentie \\
\hline Landbouw & & $-0.989^{*}$ \\
\hline \multicolumn{3}{|l|}{ Techniek } \\
\hline \multicolumn{3}{|l|}{ Economie } \\
\hline \multicolumn{3}{|l|}{ Gedrag \& maatschappij } \\
\hline \multicolumn{3}{|l|}{ Activiteit } \\
\hline Brochures, website & $0.306^{* *}$ & \\
\hline Extra bijeenkomsten & $0.488^{* * *}$ & \\
\hline Extra aandacht door docenten & $0.274^{* *}$ & \\
\hline Studiekeuzeadvies & $0.992^{* * *}$ & $0.963^{* * *}$ \\
\hline \multicolumn{3}{|l|}{ Beroepskeuzeadvies } \\
\hline Meetjaar 2010 & & $-0.546^{* *}$ \\
\hline
\end{tabular}

Bron: Quickscan 2009; 2010; Alleen significante effecten zijn weergegeven. Voor de volledige resultaten zie Bijlage 2.2.

Naast de individuele studiekeuzeadviezen laat de analyse zien dat ook de meer algemene activiteiten de kans dat de jongeren alsnog verder zijn gaan leren hebben beïnvloed. Dit geldt echter alleen voor de gediplomeerden van het MBO-BOL. Positieve effecten vinden we daarbij zowel voor het verstrekken van informatie via brochures, de website of bijvoorbeeld in het kader van extra bijeenkomsten als ook middels extra aandacht door docenten wat 
de arbeidsmarktkansen betreft. Dat deze activiteiten blijkbaar een sterker effect hebben op gediplomeerden van het $\mathrm{MBO}-\mathrm{BOL}$ is niet verrassend. De opbouw van de opleidingen in het $\mathrm{MBO}-\mathrm{BOL}$ brengt immers met zich mee dat leerlingen, in vergelijking met hun studiegenoten van het MBO-BBL, aanzienlijk meer tijd op school doorbrengen. Zij hebben dan ook een hogere kans om met deze activiteiten in aanraking te komen. Ondanks het feit dat algemene activiteiten de kans eveneens beïnvloeden, spelen zij in relatieve zin een aanzienlijk kleinere rol dan individueel geboden studiekeuzeadviezen.

Daarnaast zijn er nog een aantal relevante resultaten te zien. Zo zijn niet-westerse jongeren en jongeren van de lagere opleidingsniveaus relatief gezien vaker beïnvloed en hebben alsnog voor een vervolgopleiding gekozen. Tevens laten aanvullende analyses zien dat jongeren afkomstig van het MBO-BOL in het algemeen vaker beïnvloed zijn dan jongeren die een opleiding in het MBO-BBL hebben gevolgd. Deze resultaten zijn belangrijk aangezien onze analyses in paragraaf 2.5 van dit hoofdstuk duidelijk laten zien dat deze groepen jongeren, zeker in economisch slechte tijden, de meest kwetsbare groepen zijn.

Het algemene kwantitatieve effect van voorlichting is natuurlijk ook in directe tellingen zichtbaar. Zo geeft circa I4\% van de gediplomeerde MBO'ers van de twee onderzochte schooljaren aan dat zij door de activiteiten van de scholen zijn beïnvloed en alsnog verder zijn gaan leren. In absolute cijfers komt dit neer op bijna 20.000 jongeren per jaar die dankzij deze activiteiten alsnog voor een vervolgopleiding hebben gekozen.

Alsnog kiezen voor een vervolgopleiding is een belangrijke stap. Niet alleen omdat een hoger onderwijsniveau de kans op een betere arbeidsmarktpositie in het algemeen verhoogt, maar ook omdat dit in tijden van economische crisis nog eens extra geldt. Daarnaast geldt dat de opportuniteitskosten (de baten die men verliest door zich niet aan te bieden op de arbeidsmarkt) in economisch gezien moeilijke tijden aanzienlijk lager zijn. Indien de jongeren de vervolgopleiding echter als tussenpauze zien tot het vinden van een geschikte functie zullen deze positieve effecten snel teniet gedaan worden. Dit geldt misschien minder voor de baten van de individuele gediplomeerden zelf, maar des te meer voor de verwachte baten voor de Nederlandse kenniseconomie in het geheel.

Tabel 2.3

Intentie om vervolgopleiding voortijdig te verlaten bij aanbod van betaalde functie (\%)

\begin{tabular}{lrr} 
& Meting 2009 & Meting 2010 \\
\hline Ja & 4 & 5 \\
Weet ik nog niet & 23 & 24 \\
Nee & 73 & 72
\end{tabular}

Bron: Quickscan 2009; Quickscan 2010

Tabel 2.3 geeft een eerste indicatie dat dit echter niet het geval is. Het percentage van de jongeren dat voor een vervolgopleiding heeft gekozen en van plan is om hiermee te stoppen op het moment dat zij een betaalde functie aangeboden krijgt, is voor beide cohorten (meting 2009 en meting 2010) laag. Interessant is dat er geen duidelijke verschillen bestaan tussen enerzijds de jongeren die eerder aangaven dat zij door de schoolactiviteiten zijn beïnvloed en alsnog verder zijn gaan leren, en anderzijds de jongeren die niet zijn beïnvloed in hun keuze 
voor een vervolgopleiding. Dit toont aan dat eerstgenoemde groep op zijn minst net zo overtuigd is van de gemaakte keuze als de tweede groep.

De vraag is natuurlijk of dit hoge rendement op de heel korte termijn niet alsnog teniet gedaan wordt door een hoge uitval in het vervolg van de studie. Immers, hoofdstuk I heeft al laten zien dat bijna één op de tien gediplomeerden van het $\mathrm{MBO}$ die voor een vervolgopleiding heeft gekozen deze in het eerste leer-/schooljaar alweer heeft verlaten. Zo'n 5\%-punt hiervan verliet daarna het onderwijs ten minste tijdelijk, terwijl de overige groep van opleiding wisselde. De bevraging van de gediplomeerden van het schooljaar 2008-2009, die in het najaar van 2010 in het kader van de reguliere BVE-Monitor heeft plaatsgevonden, verschaft hierover meer inzicht. Tabel 2.4 presenteert de resultaten van een multivariate analyse voor de kans dat men de vervolgopleiding in het eerste jaar alweer voortijdig, dat wil zeggen zonder diploma, heeft verlaten.

\section{Tabel 2.4}

Belangrijkste resultaten van logit analyse voor de kans op voortijdig verlaten van vervolgopleiding

\begin{tabular}{|c|c|c|}
\hline & MBO-BOL & MBO-BBL \\
\hline \multicolumn{3}{|c|}{ Persoonlijke achtergrondkenmerken } \\
\hline Autochtoon & Referentie & Referentie \\
\hline Westerse Allochtoon & & $x$ \\
\hline \multicolumn{3}{|l|}{ Niet-westerse Allochtoon } \\
\hline \multicolumn{3}{|l|}{ Leeftijd } \\
\hline Geslacht: man & $-0.643^{* *}$ & \\
\hline \multicolumn{3}{|l|}{ Afgeronde opleiding } \\
\hline Afstudeercijfer & & $-0.519^{*}$ \\
\hline MBO niveau 1 & $0.936^{*}$ & \\
\hline MBO niveau 2 & Referentie & Referentie \\
\hline \multicolumn{3}{|l|}{ MBO niveau 3} \\
\hline \multicolumn{3}{|l|}{ MBO niveau 4} \\
\hline Opleidingssector: Economie & Referentie & Referentie \\
\hline \multicolumn{3}{|l|}{ Opleidingssector: Landbouw } \\
\hline \multicolumn{3}{|l|}{ Opleidingssector: Techniek } \\
\hline \multicolumn{3}{|c|}{ Opleidingssector: Gezondheidszorg } \\
\hline \multicolumn{3}{|c|}{ Opleidingssector: Gedrag en maatschappij } \\
\hline \multicolumn{3}{|c|}{ Doorstroom binnen opleidingsector } \\
\hline Vervolg in het BBL & & Referentie \\
\hline Vervolg in het BOL & Referentie & \\
\hline \multicolumn{3}{|l|}{ Vervolg in het HBO } \\
\hline Voldoende/goede aansluiting & $-1.052^{* *}$ & \\
\hline \multicolumn{3}{|c|}{ Individueel gesprek met studiekeuzeadvies } \\
\hline
\end{tabular}

Het eerste hoofdresultaat van de twee analyses is dat de individuele gesprekken met studiekeuzeadviezen blijkbaar geen invloed hebben op de kans dat men de gekozen vervolgoplei- 
ding binnen het eerste jaar alweer heeft verlaten. Dit betekent dat we tot dusverre kunnen concluderen dat de kwantitatieve effecten van individuele studiekeuzeadviezen inderdaad positief zijn:

- Jongeren laten zich door studiekeuzeadviezen beïnvloeden en vervolgen alsnog hun onderwijscarrière. Dit verlicht de druk op de arbeidsmarkt zeker in economisch moeilijke tijden.

- Jongeren zien de gekozen vervolgopleiding niet als een tussenpauze tot het vinden van een betaalde functie en stoppen daarom ook niet eerder met de gekozen vervolgopleiding dan jongeren die geen individueel studiekeuzeadvies hebben gekregen.

Het tweede punt kan echter ook als een negatief resultaat beschouwd worden. Immers, het ontbreken van een significant effect van studiekeuzeadviezen op voortijdige uitval in de vervolgopleiding betekent ook dat een studiekeuzeadvies de kans op voortijdige uitval blijkbaar niet vermindert. We komen later uitgebreider op dit punt terug, wanneer de kwalitatieve effecten van de studiekeuzeadviezen aan bod komen.

Terwijl bij de gediplomeerden van het MBO-BBL (met uitzondering van een zwak significant effect van het afstudeercijfer) geen van de overige opgenomen variabelen een significant effect laat zien, vinden we bij de analyse van de gediplomeerden van het MBO-BOL een aantal interessante resultaten. Zo blijken mannen de vervolgopleiding minder vaak voortijdig te verlaten en heeft het onderwijsniveau van de moeder een significante invloed. Het meest in het oog springende resultaat is echter dat jongeren die van mening zijn dat de gekozen vervolgopleiding voldoende of goed aansluit op de gevolgde opleiding een sterk verminderde kans hebben om de vervolgopleiding voortijdig te verlaten. De kwalitatieve match tussen de gekozen vervolgopleiding en de gevolgde opleiding speelt dus een uitermate belangrijke rol.

\section{Kwantitatieve effecten}

Zoals vermeld is het in het vervolg van belang om naast de kwantitatieve effecten van studiekeuzeadviezen ook op de kwalitatieve effecten in te gaan. Immers, de analyses voor de gediplomeerden van het MBO-BOL in het bijzonder laten zien dat de kans op voortijdige uitval aanzienlijk verlaagd wordt bij een voldoende of goede aansluiting van de gekozen vervolgopleiding op de gevolgde opleiding. In het vervolg staan we dan ook kort stil bij de vraag of één van de effecten van studiekeuzeadviezen een betere aansluiting met het vervolgonderwijs is. In dit geval kunnen studiekeuzeadviezen namelijk indirect wel degelijk een invloed op het succes in het vervolgonderwijs hebben. De kernresultaten van een uitgebreidere analyse laten dit effect inderdaad zien (zie Tabel 2.5). Zowel voor de gediplomeerden van het MBO-BOL als voor de gediplomeerden van het MBO-BBL geldt dat een studiekeuzeadvies de kans op een goede aansluiting tussen vervolgopleiding en gevolgde opleiding aanzienlijk verhoogt.

Niet verrassend geldt daarnaast dat jongeren die doorstromen binnen de eigen onderwijssector een betere aansluiting ervaren. Doorstroom naar het $\mathrm{HBO}$ gaat echter gepaard met een minder goede aansluiting dan doorstroom binnen het $\mathrm{MBO}^{\mathrm{r}}$. We vinden daarnaast geen verschil tussen jongeren die binnen het $\mathrm{MBO}$ van leerweg wisselen (van $\mathrm{MBO}-\mathrm{BOL}$ naar

13. Dit resultaat is al in hoofdstuk I aan de orde gekomen. 
MBO-BBL of vice versa) en jongeren die in de eigen leerweg doorleren. Tot slot laten de uitgebreidere resultaten (zie Bijlage 2.4) zien dat onder de gediplomeerden van het MBO-BOL de doorstromers vanuit het laagste niveau een betere aansluiting met de vervolgopleiding ervaren. Dit geldt eveneens voor jongeren die de gevolgde opleiding met een hoger cijfer hebben afgerond.

Tabel 2.5

Belangrijkste resultaten van logit analyse voor de kans op voldoende/goede aansluiting van vervolgopleiding op gevolgde opleiding

\begin{tabular}{lcc}
\hline Afstudeercijfer & MBO-BOL & MBO-BBL \\
\hline Doorstroom binnen opleidingsector & $0.173^{* *}$ & $0.962^{* *}$ \\
\hline Vervolg in het BBL & $0.368^{* *}$ & Referentie \\
\hline Vervolg in het BOL & Referentie & $-1.431^{* *}$ \\
\hline Vervolg in het HBO & $-0.841^{* *}$ & $0.995^{* *}$ \\
\hline Individueel gesprek met studiekeuzeadvies & & $0.543^{* *}$ \\
\hline
\end{tabular}

Bron: BVE-Monitor 2010; Voor de volledige resultaten zie Bijlage 2.4.

\subsection{Succes van beroepskeuzegesprekken}

Terwijl individuele studiekeuzeadviezen jongeren stimuleren om alsnog verder te gaan leren, dient de voorlichting aan examenkandidaten over de beroepsmogelijkheden de transitie van opleiding naar werk versoepelen. Goede voorlichting zou schoolverlaters niet alleen moeten helpen om snel werk te vinden (kwantitatieve effect: kleiner aantal werklozen), maar ook de kans vergroten dat het gevonden werk goed aansluit op de gevolgde opleiding (kwalitatieve effect). Het is goed denkbaar dat zulke voorlichting extra belangrijk wordt in tijden waarin banen schaars zijn.

Eerder onderzoek onder de gediplomeerden van het hoger beroepsonderwijs (HBO) heeft laten zien dat beroepskeuzevoorlichting inderdaad positief lijkt te werken op arbeidsmarktuitkomsten (zie ROA, 2009b). Dit geldt zowel op het niveau van de individuele afgestudeerden als geaggregeerd op het niveau van opleidingen. Daarbij dient opgemerkt te worden dat op individueel niveau gedeeltelijk sprake kan zijn van omgekeerde causaliteit, waarbij succesvollere afgestudeerden een gunstiger beeld overhouden van de voorlichting. Het hier geanalyseerde databestand (BVE-Monitor 20IO) biedt de kans om voor het MBO het gevaar van omgekeerde causaliteit te voorkomen en analyses op individueel niveau te bieden. In tegenstelling tot het onderzoek onder de HBO-afgestudeerden onderzoeken wij namelijk niet de tevredenheid over de gegeven voorlichting, maar de vraag of men een individueel gesprek over de arbeidsmarktkansen met een medewerker van de school heeft gehad.

De opzet van deze paragraaf is daarbij vergelijkbaar met de opzet van de vorige paragraaf over de doorstroom naar een vervolgopleiding. We analyseren in eerste instantie de kwantitatieve effecten van individuele gesprekken (de kans op werk) en in tweede instantie de kwalitatieve effecten (de kwaliteit van het gevonden werk). 


\section{Kwantitatieve effecten: Kans op werk}

De beschikbare data bieden de mogelijkheid om op twee momenten de kans op werk te analyseren: a) kans op werk binnen 2 maanden na het behalen van het diploma en b) kans op werk I, 5 jaar na het afronden van de opleiding. Het eerste moment zullen wij in het vervolg typeren als 'intredemoment' en het tweede als 'enquêtemoment'. Tabel 2.6 presenteert de resultaten van twee multivariate analyses voor de kans op werk. Naast de centrale variabele (individueel gesprek over arbeidsmarktkansen) wordt in beide analyses voor persoonlijke en sociale achtergrondkenmerken gecontroleerd en is de woonregio in de analyse opgenomen. Verder zijn het gemiddelde afstudeercijfer, het gevolgde opleidingsniveau en de gevolgde opleidingsector opgenomen. In beide analyses is ook de vraag opgenomen of de respondent tijdens de opleiding problemen had met het vinden van een stageplek (MBO-BOL) of leerplek (MBO$\mathrm{BBL}$ ). In de analyse over het enquêtemoment wordt ten slotte rekening gehouden met een eventuele werkloosheid van minimaal twee maanden op het intredemoment.

We starten de beschrijving van de analyses met de centrale vraag of individueel geboden beroepskeuzeadvies de kans op werk inderdaad kan verhogen. De resultaten laten zien dat dit wel geldt voor de kans op werk op het intredemoment voor de gediplomeerden van het MBO-BOL, maar niet voor de gediplomeerden van het MBO-BBL. Eveneens zien we geen directe invloed op de kans op werk op het enquêtemoment. Dat een door de school gegeven beroepskeuzeadvies vooral invloed heeft op de directe arbeidsmarktintrede van de gediplomeerden van het $\mathrm{MBO}-\mathrm{BOL}$ is niet verrassend. In vergelijking met hun studiegenoten van MBO-BBL staan zij immers verder weg van de arbeidsmarkt en zijn daarom in de regel minder goed op de hoogte van wat er zoal speelt op de arbeidsmarkt. Beroepskeuzeadvies aan leerlingen van MBO-BOL kan dit tekort aan informatie opvullen en lijkt inderdaad een uitermate effectief middel.

Het feit dat het effect van een beroepskeuzeadvies al binnen anderhalf jaar lijkt weg te ebben, is in eerste instantie een nogal negatieve uitkomst. De analyses voor de kans op werk op het enquêtemoment laten echter duidelijk zien dat de startfase (intredemoment) en het succes hiervan van groot belang zijn voor het vervolg van de carrière. Jongeren die direct na het behalen van het diploma ten minste twee maanden werkloos zijn voordat ze hun eerste betaalde functie vinden, kennen een significant lagere kans op werk op het enquêtemoment. Indirect speelt het beroepskeuzeadvies dat een jongere in een individueel gesprek heeft gekregen daarmee ook op latere momenten nog een belangrijke rol.

De analyses laten verder een aantal interessante resultaten zien. Zo wordt nog eens duidelijk dat niet-westerse jongeren een aanzienlijk moeilijkere start op de arbeidsmarkt kennen. Geldt dit bij de gediplomeerden van het MBO-BOL op zowel het intrede- als het enquêtemoment, voor de gediplomeerden van het MBO-BBL heeft de etniciteit vooral invloed op de kans op werk op het enquêtemoment. Naast de etnische afkomst vinden we bij de jongeren van het MBO-BOL ook een invloed van de thuissituatie (gemeten op I5 jarige leeftijd). ${ }^{\mathrm{I}}$ Jongeren die op dat moment met beide ouders thuis woonden hebben op het enquêtemoment een grotere kans op werk. Het opleidingsniveau van de ouders lijkt verder geen rol te spelen. Is het bij de gediplomeerden van het MBO-BOL de vraag of men bij beide ouders woonde, bij de gedi-

I4. Zie hiervoor Bijlage 2.5. 
plomeerden van het MBO-BBL zien we een significant effect van het opleidingsniveau van de ouders. Vooral respondenten met een hoogopgeleide moeder hebben een grotere kans op werk op het intredemoment. Door de betere start op de arbeidsmarkt zal dit effect dan ook op latere momenten nog voelbaar zijn.

Tabel 2.6

Belangrijkste resultaten van logit analyse op kans op werk: intrede- en enquêtemoment

\begin{tabular}{|c|c|c|c|c|}
\hline & \multicolumn{2}{|c|}{ MBO-BOL } & \multicolumn{2}{|c|}{ MBO-BBL } \\
\hline & Intrede & Enquête & Intrede & Enquête \\
\hline Man & $0.341^{*}$ & $0.518^{*}$ & & $0.582^{* *}$ \\
\hline Leeftijd & $-0.039 * *$ & & & \\
\hline Autochtoon & Referentie & Referentie & Referentie & Referentie \\
\hline \multicolumn{5}{|l|}{ Westerse allochtoon } \\
\hline Niet-westerse allochtoon & $-0.678^{* * *}$ & $-0.708^{* *}$ & & $-0.946^{* * *}$ \\
\hline \multicolumn{5}{|l|}{ Afstudeercijfer } \\
\hline \multicolumn{5}{|l|}{ Opleidingsniveau } \\
\hline Niveau 1 & & $-0.836^{*}$ & & \\
\hline Niveau 2 & Referentie & Referentie & Referentie & Referentie \\
\hline Niveau 3 & $0.665^{* *}$ & $0.718^{* *}$ & $1.121^{* * *}$ & $0.798^{*}$ \\
\hline Niveau 4 & $0.480^{* *}$ & $0.793^{* * *}$ & $1.136^{* *}$ & $1.716^{* *}$ \\
\hline \multicolumn{5}{|l|}{ Opleidingssector } \\
\hline \multicolumn{5}{|l|}{ Landbouw } \\
\hline \multicolumn{5}{|l|}{ Techniek } \\
\hline Economie & Referentie & Referentie & Referentie & Referentie \\
\hline Gezondheidszorg & $0.890^{* * *}$ & $0.773^{* *}$ & $1.071^{*}$ & $0.796^{* * *}$ \\
\hline Gedrag \& Maatschappij & & & & $0.776^{* *}$ \\
\hline Gesprek: Arbeidsmarkt & $0.392^{* *}$ & & & \\
\hline Problemen met vinden stage/BPV & $-0.573^{* * *}$ & $-0.556^{* *}$ & $-1.505^{* * *}$ & $-0.676^{* * *}$ \\
\hline Intredewerkloosheid >=2 maanden & X & $-2.147^{* * *}$ & X & $-2.295^{* * *}$ \\
\hline
\end{tabular}

Bron: BVE-Monitor 2010. Alleen significante effecten zijn weergegeven. Voor de volledige resultaten zie Bijlage $2.5 a$ en $2.5 \mathrm{~b}$.

Verder is het niet verrassend dat het gevolgde onderwijsniveau een belangrijke factor speelt bij de kans op werk. Opvallend is daarbij dat we slechts bij de gediplomeerden van het MBO-BOL (op het enquêtemoment) vinden dat jongeren met een startkwalificatie (MBO-niveau 2) het beter doen dan jongeren zonder startkwalificatie. Aangezien dit effect slechts significant is op IO\% niveau, en dus relatief sterk op toeval kan berusten, kunnen de voorliggende analyses de waarde van een startkwalificatie niet direct bevestigen. Voor de gediplomeerden van niveau 3 (BOL) en niveau 4 (BOL en BBL) vinden we daarentegen een significant hogere kans op werk dan voor de gediplomeerden van niveau 2. Dit geldt in principe zowel voor de gediplomeerden van het MBO-BOL als de gediplomeerden van het MBO-BBL.

De analyses laten tot slot zien dat er een duidelijk waarschuwingssignaal dient uit te gaan van de vraag of men tijdens, of voor aanvang van, de opleiding problemen ondervond bij de zoektocht naar een stageplaats/leerplek. Dat het antwoord op deze vraag sterk correleert met 
de kans op werk op zowel het intredemoment als het enquêtemoment kan op twee achterliggende factoren rusten. Om te beginnen kan het ervaren van problemen bij het vinden van een stage- dan wel leerplek er al in een vroeg stadium op wijzen dat deze opleiding een moeilijke arbeidsmarkt kent. Bovendien kan dit erop duiden dat persoonlijke en/of opleidingsgerelateerde factoren de intrede op de arbeidsmarkt bemoeilijken, waarvoor in deze analyses echter niet gecontroleerd is. Tegen het tweede argument (en daarmee dus voor het eerste argument) spreken een aantal van onze resultaten die in het vervolg van dit hoofdstuk aan bod komen. Problemen bij het vinden van een stage-/leerplek lijken namelijk niet de kwaliteit van het gevonden werk te voorspellen. Deze problemen voorspellen slechts de kans op werk als zodanig.

\section{Kwalitatieve effecten: Aansluiting tussen werk en opleiding}

Het kwantitatieve effect dat de aan het einde van het MBO geboden beroepskeuzeadviezen de kans op werk verhogen is natuurlijk een uitermate belangrijk resultaat. Hoewel het vinden van werk weliswaar een belangrijke stap is, is het vinden van passend werk een noodzakelijke vervolgstap. In deze paragraaf gaan we dan ook in op een belangrijke indicator voor de kwaliteit van het beroepsonderwijs, namelijk de mate waarin de gediplomeerden die zich op de arbeidsmarkt aanbieden passend werk vinden. Beschrijvend zijn we op dit aspect al uitgebreid ingegaan in hoofdstuk I. De term passend werk kan betrekking hebben op twee dimensies: horizontaal en verticaal. De horizontale dimensie betreft de vraag of de huidige functie goed aansluit op de gevolgde onderwijssector qua richting. De verticale dimensie heeft betrekking op de aansluiting tussen het niveau van het werk en het niveau van de gevolgde opleiding.

Tabel 2.7 laat voor de vier onderscheiden opleidingsniveaus het percentage gediplomeerden zien dat volgens eigen inschatting $a$ ) in het eigen domein werkt en b) een functie heeft die qua niveau overeenkomt met minimaal het niveau van de gevolgde opleiding.

Tabel 2.7

Match tussen opleiding en functie

$\begin{array}{llllllllll} & \text { BOL 1 } & \text { BOL 2 } & \text { BOL 3 } & \text { BOL 4 } & \text { BBL 1 } & \text { BBL 2 } & \text { BBL 3 } & \text { BBL 4 } & \text { HB0 } \\ \text { Werk in eigen domein } & 77 & 59 & 78 & 76 & 51 & 64 & 79 & 83 & 79 \\ \text { Werk op niveau } & 79 & 74 & 78 & 87 & 44 & 69 & 68 & 84 & 79\end{array}$

Bron: BVE-Monitor 2010

Werkzaam zijn buiten het eigen vakgebied gaat in de regel vaker gepaard met werkzaam zijn onder het eigen niveau. Dit blijkt duidelijk uit Tabel 2.8. Verreweg de meeste schoolverlaters die binnen hun vakdomein werkzaam zijn werken ook op hun opleidingsniveau. Indien de schoolverlater echter een functie buiten zijn eigen vakdomein aanvaardt, neemt de kans aanzienlijk toe dat deze functie ook beneden het gevolgde opleidingsniveau is.

Tabel 2.8

$\%$ werkzaam op minimaal eigen opleidingsniveau

\begin{tabular}{|llllllllll} 
& BOL 1 & BOL 2 & BOL 3 & BOL 4 & BBL 1 & BBL 2 & BBL 3 & BBL 4 & HB0 \\
\hline Indien werkzaam in eigen domein & 82 & 89 & 86 & 93 & 63 & 81 & 75 & 89 & 85 \\
\hline Indien werkzaam buiten eigen domein & 66 & 54 & 47 & 38 & 44 & 35 & 44 & 40 & 51
\end{tabular}

Bron: BVE-Monitor 2010 
Om de vraag te beantwoorden of beroepskeuzeadviezen gegeven aan het einde van het MBO inderdaad tot een betere aansluiting tussen werk en gevolgde opleiding leiden, gaan we navolgend in op drie analyses: a) de kans dat men werk in het eigen domein heeft gevonden, b) de kans dat men werk op miniaal het eigen niveau heeft gevonden en c) de kans dat men van mening is dat het werk goed aansluit op de gevolgde opleiding. Om met de bovenstaande discussie over de relatie tussen de kans op werk in het eigen domein en de kans op werk op minimaal het eigen niveau rekening te houden, controleren we in de analyses voor de horizontale match dan wel voor de verticale match. Tabel 2.9 presenteert de belangrijkste resultaten uit deze drie analyses afzonderlijk voor de gediplomeerden van het MBO-BOL en de gediplomeerden van het MBO-BBL. De volledige analyseresultaten zijn in Bijlage 2.6 opgenomen.

Tabel 2.9

Kans op werk in eigen domein, op eigen niveau en kans op algemeen goede aansluiting

\begin{tabular}{|c|c|c|c|c|c|c|}
\hline & \multicolumn{3}{|c|}{$\mathrm{MBO}-\mathrm{BOL}$} & \multicolumn{3}{|c|}{ MBO-BBL } \\
\hline & Horizontaal & Verticaal & Algemeen & Horizontaal & Verticaal & Algemeen \\
\hline Afstudeercijfer & & $0.214^{* * *}$ & & & & \\
\hline \multicolumn{7}{|l|}{ Opleidingsniveau } \\
\hline Niveau 1 & & & & & $-0.843^{* * *}$ & \\
\hline Niveau 2 & Ref. & Ref. & Ref. & Ref. & Ref. & Ref. \\
\hline Niveau 3 & $0.635^{* * *}$ & & & $0.767^{* * *}$ & $-0.690^{* * *}$ & $0.513^{* *}$ \\
\hline Niveau 4 & $0.455^{* *}$ & & $-0.523^{* *}$ & $1.114^{* * *}$ & & \\
\hline \multicolumn{7}{|l|}{ Opleidingssector } \\
\hline Landbouw & & & & $0.500^{*}$ & $-0.527^{* *}$ & \\
\hline Techniek & & & & $0.767^{* * *}$ & & \\
\hline Economie & Ref. & Ref. & Ref. & Ref. & Ref. & \\
\hline Gezondheidszorg & $1.095^{* * *}$ & $0.519^{* *}$ & $-0.437^{* *}$ & $1.400^{* * *}$ & $0.896^{* * *}$ & \\
\hline Gedrag \& Maatschappij & $0.875^{* * *}$ & $1.032^{* * *}$ & & $1.142^{* * *}$ & $1.984^{* * *}$ & \\
\hline Gesprek: Arbeidsmarkt & $0.310^{*}$ & & $0.447^{* *}$ & & & $0.673^{* * *}$ \\
\hline Problemen met vinden stage & & & $-0.588^{* * *}$ & & & $-0.835^{* *}$ \\
\hline$>=2 \mathrm{~m}$ intredewerkloosheid & & & $-0.760 * * *$ & & & $-1.105^{* * *}$ \\
\hline Verticale match & $1.959^{* * *}$ & $x$ & & $1.451^{* * *}$ & $x$ & $0.356^{*}$ \\
\hline Horizontale match & $x$ & $1.994^{* * *}$ & $0.870^{* * *}$ & $x$ & $1.455^{* * *}$ & $0.535^{* *}$ \\
\hline
\end{tabular}

Bron: BVE-Monitor 2010. Voor de volledige resultaten van de analyses, zie Bijlage 2.6a en 2.6b. X: niet opgenomen in analyses.

In eerste instantie bevestigen de resultaten de directe telling die we in Tabel 2.8 hebben gepresenteerd. De kans om in het eigen domein (horizontale match) werkzaam te zijn is inderdaad positief gecorreleerd met de kans om op eigen niveau (verticale match) werkzaam te zijn en vice versa. Een functie die qua richting bij de gevolgde opleiding past beïnvloedt het algemene oordeel over de aansluiting: werkzaam zijn binnen het eigen domein gaat gepaard met een betere aansluiting. Dat de match tussen het niveau van het werk en het niveau van de opleiding in de regel geen invloed heeft op de algemene aansluiting lijkt in lijn met 
andere vergelijkbare onderzoeken. ${ }^{\text {Is }}$ Zo laten Allen en Van der Velden (200I) zien dat werken onder het eigen opleidingsniveau (verticale mismatch) niet per definitie gepaard gaat met een onderbenutting van capaciteiten. Dit argument geldt inderdaad niet, ofwel in duidelijk mindere mate, voor een horizontale mismatch. In dit geval missen de gediplomeerden namelijk zonder twijfel vereiste competenties die tot de gekozen arbeidsmarktsector behoren.

De resultaten laten daarnaast zien dat de gediplomeerden van de niveaus 3 en 4 een relatief hogere kans hebben om in het eigen domein werkzaam te zijn, maar dat dit niet per definitie geldt voor het vinden van werk op het eigen niveau. Het tweede resultaat is gerelateerd aan het feit dat met afnemend niveau het aantal functies dat nog een lager onderwijsniveau vereist afneemt. Ook vinden we dat de gediplomeerden van de relatief sterkere beroepsgerichte opleidingen (Gezondheidszorg en Gedrag \& Maatschappij) makkelijker een functie vinden in het eigen domein en ook op minimaal het eigen niveau. Vraag en aanbod lijken bij deze sectoren beter op elkaar aan te sluiten dan bij de sector Economie.

De centrale vraag is echter wat de impact is van het beroepskeuzeadvies. Het antwoord daarop lijkt wederom te verschillen tussen de gediplomeerden van het $\mathrm{MBO}-\mathrm{BOL}$ en de gediplomeerden van het MBO-BBL. Terwijl bij de tweede groep een beroepskeuzeadvies weliswaar tot een algemene betere aansluiting leidt, vinden we alleen bij de gediplomeerden van het MBO-BOL een effect op de objectieve aansluiting qua niveau of richting. Een persoonlijk gesprek met beroepskeuzeadvies lijkt bij deze groep namelijk de kans te vergroten dat de respondent een functie in het eigen domein vindt. Geen direct effect wordt echter gevonden voor het niveau van het werk. Dit lijkt te bevestigen dat scholen een netwerk bezitten van contacten met het werkveld dat het voor de gediplomeerden niet alleen makkelijker maakt om snel werk te vinden, maar ook werk dat qua richting goed aansluit op de gevolgde opleiding. Scholen lijken echter geen invloed te hebben op het uiteindelijke niveau van de functie. Dat dit effect niet gevonden wordt voor de gediplomeerden van het MBO-BBL ondersteunt de eerder gemaakte hypothese dat beroepskeuzeadviezen vooral van belang zijn voor jongeren die relatief gezien het verst van de arbeidsmarkt afstaan, namelijk de jongeren die een opleiding in het MBO-BOL volgen.

Een algemeen positief effect op de match tussen het gevonden werk en de gevolgde opleiding zal zonder twijfel ook een positief effect moeten hebben op de kans dat de gediplomeerden de aangeleerde capaciteiten voldoende kunnen benutten. De belangrijkste resultaten uit een uitgebreide multivariate analyse voor de kans dat de werkende jongeren capaciteiten voldoende of goed kunnen benutten bevestigen dit (zie Tabel 2.IO). We zien echter wederom dat dit vooral voor de gediplomeerden van het MBO-BOL van toepassing is. De resultaten laten daarnaast zien dat een werkloosheidsperiode van minimaal 2 maanden tijdens het intredemoment de mogelijkheid om de capaciteiten te benutten verlaagt, dat werken op het eigen niveau een positief effect heeft (echter bij de MBO-BOL gediplomeerden slechts op IO\% significantieniveau) en dat vooral werk in het eigen domein van groot belang is om een voldoende of zelfs goede benutting van de eigen capaciteiten te garanderen.

I5. Het effect van de verticale match op de algemene aansluiting is weliswaar positief voor de gediplomeerden van het MBO-BBL, maar slechts op een significantieniveau van IO\%. 
Tabel 2.10

Analyse voor de kans dat capaciteiten voldoende/goed benut worden

\begin{tabular}{lcc} 
& MBO-BOL & MBO-BBL \\
\hline Gesprek: Arbeidsmarkt & $0.312^{* *}$ & $-0.697^{*}$ \\
\hline$>=2 m$ intredewerkloosheid & $-0.531^{* *}$ & $0.343^{* *}$ \\
Werkzaam op eigen niveau & $0.300^{*}$ & $0.581^{* * *}$
\end{tabular}

Bron: BVE-Monitor 2010; Voor de volledige resultaten van de analyses, zie Bijlage 2.7a en 2.7b.

\section{Kwalitatieve effecten: carrièreperspectieven}

Tot nu toe hebben onze analyses positieve effecten van een beroepskeuzeadvies op de intrede op de arbeidsmarkt in zowel kwantitatieve als kwalitatieve zin laten zien. Nadeel van deze analyses is dat we niet kunnen vaststellen of deze effecten ook op langere termijn blijven bestaan. Tot slot van dit hoofdstuk staan we daarom kort stil bij een indicatie van de midden en lange termijn effecten. We doen dit aan de hand van de vraag of het gevonden werk volgens de respondent zelf goede of heel goede carrièreperspectieven biedt. Tabel 2.II presenteert de hoofdresultaten van een uitgebreidere analyse. Voor de volledige resultaten wordt verwezen naar Bijlage 2.7.

Tabel 2.11

Analyse voor de kans dat werk goede carrièreperspectieven biedt

\begin{tabular}{|c|c|c|}
\hline & MBO-BOL & MBO-BBL \\
\hline Afstudeercijfer & & $0.167^{* * *}$ \\
\hline \multicolumn{3}{|l|}{ Opleidingsniveau } \\
\hline Niveau 1 & $-1.494^{* * *}$ & \\
\hline Niveau 2 & Ref. & Ref. \\
\hline Niveau 3 & & $0.359^{*}$ \\
\hline \multicolumn{3}{|l|}{ Niveau 4} \\
\hline \multicolumn{3}{|l|}{ Opleidingssector } \\
\hline Landbouw & $-0.554^{* * *}$ & $-0.635^{* *}$ \\
\hline Techniek & $-0.395^{* *}$ & \\
\hline Economie & Ref. & Ref. \\
\hline \multicolumn{3}{|l|}{ Gezondheidszorg } \\
\hline Gedrag \& Maatschappij & $-0.477^{* * *}$ & \\
\hline Gesprek: Arbeidsmarkt & $0.391^{* * *}$ & $0.467^{* * *}$ \\
\hline \multicolumn{3}{|l|}{ Problemen met vinden stage } \\
\hline$>=2 \mathrm{~m}$ intredewerkloosheid & $-0.618^{* * *}$ & $-1.388^{* * *}$ \\
\hline Werkzaam op eigen niveau & $0.583^{* * *}$ & \\
\hline Werkzaam in eigen domein & $0.264^{*}$ & \\
\hline
\end{tabular}

Tijdens een persoonlijk gesprek op school geboden beroepskeuzeadviezen blijken ook wat betreft de carrièreperspectieven de kansen van recent gediplomeerde MBO'ers te vergroten. 
Zowel voor de gediplomeerden van het $\mathrm{MBO}-\mathrm{BOL}$ als voor de gediplomeerden van het $\mathrm{MBO}-\mathrm{BBL}$ vinden we een positief significant effect. Opvallend is verder dat een werkloosheidsperiode van minimaal twee maanden direct na het behalen van het diploma ertoe leidt dat de werkende gediplomeerden op het enquêtemoment (ca. I,5 jaar later) van mening zijn dat hun huidige functie minder goede carrièreperspectieven biedt. Dit resultaat versterkt wederom het belang van het snel vinden van werk voor de gediplomeerden van het MBO. En aangezien arbeidsmarktgesprekken hierin een belangrijke rol spelen, zal het effect van een persoonlijk arbeidsmarktgesprek met beroepskeuzeadvies in de regel nog sterker uitvallen dan de analyse in eerste instantie laat zien.

De analyse laat verder een aantal voor de hand liggende resultaten zien voor de gediplomeerden van het MBO-BOL. De gediplomeerden van het MBO-BOL niveau I kennen aanzienlijk minder goede carrièreperspectieven, terwijl werkzaam zijn in een functie op minimaal het eigen niveau en werkzaam zijn in een functie in het eigen domein de kans op goede carrièreperspectieven verhogen.

\subsection{Conclusie en evaluatie}

Jongeren stimuleren om verder te gaan leren. Dit was het centrale onderdeel van het School-Ex Programma dat in het kader van het Actieplan Jeugdwerkloosheid in het voorjaar van 2009 van start is gegaan en een vervolg kreeg in 20IO. Het voorliggende onderzoek tracht een bijdrage te leveren aan de evaluatie van het School-Ex Programma door te analyseren wat de effecten van studie- en beroepskeuzeadviezen zijn.

Onderstaand schema vat de belangrijkste resultaten van het onderzoek samen. Zoals vermeld concentreerde het onderzoek zich op een tweetal aspecten van het School-Ex Programma: studie- en beroepskeuzeadviezen.

\section{Schema 2.1}

Samenvattende figuur

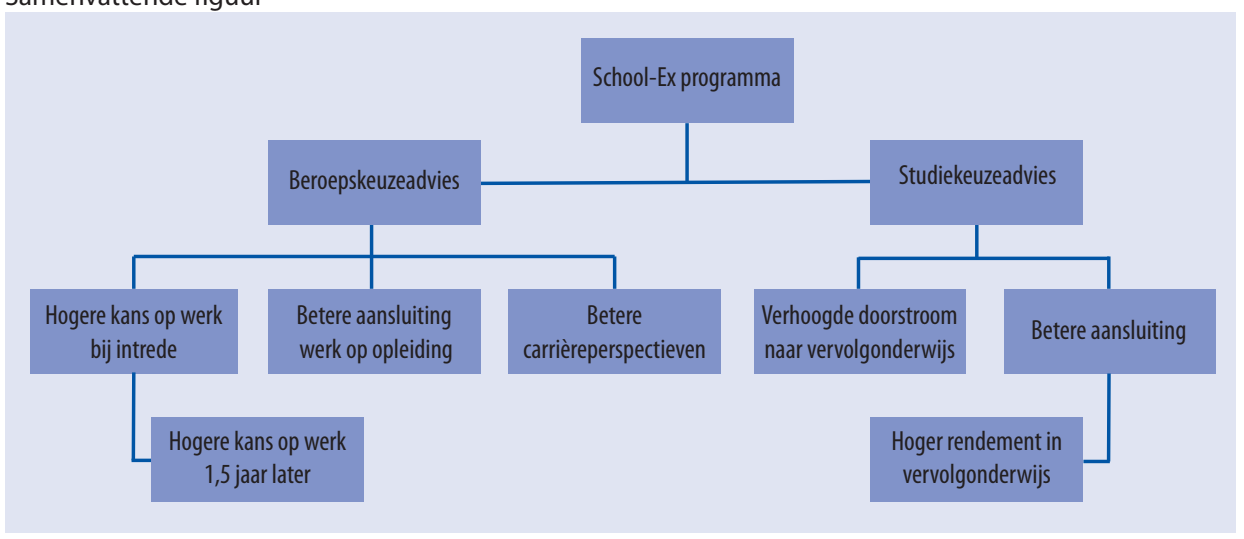

De effecten van studiekeuzeadviezen worden in het rechter gedeelte van het schema gepresenteerd. Het belangrijkste resultaat is dat persoonlijke studiekeuzeadviezen inderdaad de 
kans vergroot hebben dat jongeren na het behalen van het MBO-diploma hun onderwijscarrière hebben voortgezet. Als gevolg van de verhoogde doorstroom naar een vervolgopleiding werd de druk op de arbeidsmarkt verlicht en groeide de jeugdwerkloosheid minder sterk dan verwacht. Ook in economisch goede tijden mag het effect van deze studiekeuzeadviezen niet onderschat worden: een hoger opleidingsniveau gaat in de regel gepaard met een betere arbeidsmarktsituatie zowel direct na het verlaten van de opleiding als later in de carrière. Hiervan profiteert niet alleen de jongere zelf maar ook de Nederlandse kenniseconomie als geheel.

Studiekeuzeadviezen hebben echter ook sterke kwalitatieve effecten: de ondersteuning van MBO-scholen leidt tot een betere aansluiting tussen de gevolgde opleiding en de gekozen vervolgopleiding. Jongeren komen daardoor vaker op een plek terecht die ansluit bij hun capaciteiten. Dit verlaagt de kans dat men de vervolgopleiding al op korte termijn weer voortijdig verlaat aanzienlijk. Hiermee worden de tijdelijke kwantitatieve effecten van de studiekeuzeadviezen meer permanent en dragen deze niet alleen bij aan een verlichting van de druk op de arbeidsmarkt maar ook aan een verhoging van de beschikbare kennis in Nederland.

Studiekeuzeadviezen zijn echter niet voldoende. Aangezien ook in economisch slechte tijden ongeveer één op de twee MBO-gediplomeerden zich op de arbeidsmarkt aanbiedt, dienen studiekeuzeadviezen aangevuld te worden met, dan wel vervangen te worden door, beroepskeuzeadviezen. Dit geldt in het bijzonder voor jongeren die aan het plafond van hun mogelijke onderwijsniveau aangekomen zijn en voor jongeren die de beroepsopleidende leerweg (MBO-BOL) hebben gevolgd. De laatstgenoemde groep heeft namelijk een grotere afstand tussen opleiding en arbeidsmarkt dan de jongeren die de beroepsbegeleidende leerweg (MBO$\mathrm{BBL}$ ) hebben gevolgd. Individuele beroepskeuzegesprekken, waarin jongeren bijvoorbeeld toegang krijgen tot het netwerk dat scholen met potentiële werkgevers hebben, kennen hun eigen positieve effecten (zie linkerkant van Schema 2.I). Jongeren die een beroepskeuzeadvies hebben gekregen zijn minder vaak direct na het verlaten van de opleiding werkloos. Deze kleinere kans op intredewerkloosheid heeft ook een positief effect op de kans op werk anderhalf jaar later, wat de baten van beroepskeuzegesprekken verder onderbouwt.

Vergelijkbaar met de effecten van studiekeuzeadviezen vinden we daarnaast ook bij de beroepskeuzeadviezen belangrijke kwalitatieve effecten. Zo ervaren de jongeren die een beroepskeuzeadvies hebben gekregen in de regel een betere aansluiting tussen werk en gevolgde opleiding en daardoor een betere benutting van hun capaciteiten. Hiermee wordt aan de ene kant voorkomen dat jongeren de aangeleerde capaciteiten niet kunnen gebruiken en met het probleem van "use it or lose it" geconfronteerd worden. Aan de andere kant wordt voorkomen dat jongeren in functies terecht komen die niet bij hun capaciteiten en verwachtingen aansluiten en a) door frustratie op zoek gaan naar ander werk of b) met de consequenties van ontslag moeten omgaan. Dat beroepskeuzeadviezen uiteindelijk ook op de lange termijn positieve effecten kunnen hebben wordt tot slot ondersteund doordat jongeren die een beroepskeuzeadvies hebben gekregen in de regel betere carrièreperspectieven verwachten.

Samenvattend kunnen we vaststellen dat door MBO-scholen aangeboden studie- en/of beroepskeuzeadviezen zowel van groot belang zijn voor de individuele gediplomeerde alsook voor de Nederlandse kenniseconomie in zijn geheel. 


\section{Een nadere analyse van redenen voor voortijdig schoolverlaten}

\subsection{Inleiding}

Nederland behoort tot de meest succesvolle Europese landen wanneer het om de aanpak van voortijdig schoolverlaten gaat (Ministerie van OC\&W, 20II). Het percentage voortijdig schoolverlaters is sinds de eeuwwisseling met $35 \%$ gedaald. Ondanks dit succes koestert de Nederlandse overheid de ambitie om het aantal vsv'ers verder terug te dringen van 39.600 in 2010 tot maximaal 25.000 in 20I6. In het licht van deze ambitie is het onverminderd belangrijk om te begrijpen waarom jongeren het onderwijs voortijdig verlaten. Het is ook belangrijk om te weten welke consequenties dit heeft voor de betrokken jongeren. Keren de jongeren weer terug naar het onderwijs of vinden ze een baan? In de afgelopen twee jaren is er al in twee rapportages op deze vragen ingegaan (ROA, 2009, 20IO). Doordat de resultaten in deze rapportages echter gebaseerd waren op analyses afkomstig van één bepaalde meting (2007, respectievelijk 2009) konden deze rapportages geen echt diepgaande analyses bieden. Bovendien is het tot nu toe niet mogelijk gebleken om eventuele veranderingen over de tijd te laten zien. In dit hoofdstuk willen we precies deze lacunes opvullen door gebruik te maken van de onderzoeken die vanaf 2007 tot en met 2010 hebben plaatsgevonden. Vragen die aan de orde komen zijn bij welke redenen sprake is van onderliggende verbanden, maar ook of de recente economische crisis tot een verandering heeft geleid in de samenstelling van de groep voortijdige schoolverlaters (bijvoorbeeld relatief minder 'opstappers' en relatief meer 'risicojongeren').

Daarnaast trachten we, zoals in de rapportage Zonder diploma: aanleiding, kansen en toekomstintenties (ROA, 2009) al kort aan bod is gekomen, een koppeling te maken tussen de resultaten afkomstig van de enquêtes en de bestanden van DUO. Daarmee wordt het mogelijk om vast te stellen welke jongeren teruggekeerd zijn in het onderwijs. Door de vraag naar de reden voor het voortijdig verlaten van het onderwijs aan deze gegevens te koppelen ontstaat de uitermate interessante mogelijkheid om na te gaan in hoeverre bepaalde redenen 'slechts' voorbode zijn voor een tijdelijk en kort vertrek uit het onderwijs en welke redenen een zodanige barrière vormen dat jongeren ook na 2-4 jaren de weg terug naar het onderwijs niet hebben gevonden.

De resultaten in het voorliggende hoofdstuk zijn afkomstig van steekproeven onder voortijdige schoolverlaters van de metingen $2007 \mathrm{t} / \mathrm{m}$ 20IO, die betrekking hebben op jongeren die in de schooljaren respectievelijk 2005/2006, 2006/2007, 2007/2008 of 2008/2009 een opleiding in het $\mathrm{VMBO}$, het $\mathrm{MBO}$, het HAVO of het VWO volgden en deze zonder diploma hebben verlaten (VSV zonder diploma). 


\subsection{Wat zijn de belangrijkste redenen voor voortijdig schoolverlaten?}

Net als vorig jaar is een lijst met mogelijke redenen voor het voortijdige vertrek uit het onderwijs aan schoolverlaters voorgelegd. Bij elk van deze redenen wordt eerst aan de schoolverlaters gevraagd in hoeverre deze een rol hebben gespeeld bij hun beslissing om met de opleiding te stoppen. Vervolgens wordt hen gevraagd om aan te geven welk van deze redenen voor hen het belangrijkste was. Op twee punten na is de lijst met redenen in 2010 hetzelfde als in 2009. Ten eerste is een nieuwe antwoordcategorie toegevoegd, namelijk "ik voelde me niet veilig op de school". Ten tweede, de antwoordcategorie "de opleiding voldeed niet aan de verwachtingen" is nader uitgesplitst in drie deelcategorieën, te weten "de opleiding was inhoudelijk (toch) niet wat ik wilde", "ik vond het niveau van de opleiding te laag", en "de opleiding was slecht georganiseerd". Om een beeld te krijgen van de mate waarin deze veranderingen tot een substantiële verandering in de verdeling van de antwoorden hebben geleid staan in tabel 3.I per reden het aandeel respondenten in 2009 en 2010 dat aangaf dat de betreffende reden voor hen de belangrijkste reden was om met de opleiding te stoppen.

Tabel 3.1

Belangrijkste reden om met de opleiding te stoppen, 2009 en 2010 (\%)

\begin{tabular}{|c|c|c|}
\hline Reden & 2009 & 2010 \\
\hline opleiding voldeed niet aan mijn verwachtingen (niet nader gespecificeerd) & 19,4 & 11,6 \\
\hline - de opleiding was inhoudelijk (toch) niet wat ik wilde & n.v.t & 5,9 \\
\hline - de opleiding was slecht georganiseerd & n.v.t & 4,2 \\
\hline - ik vond het niveau van de opleiding te laag & n.v.t & 1,1 \\
\hline anders & 14,4 & 18,8 \\
\hline psychische problemen & 10,8 & 8,6 \\
\hline ik wilde liever gaan werken & 9,5 & 8,4 \\
\hline ziekte & 7,7 & 7,1 \\
\hline de opleiding was te moeilijk en/of gezakt voor het eindexamen & 4,8 & 5,4 \\
\hline relatieproblemen/gezinsproblemen (bijv. scheiding van ouders) & 4,1 & 5,0 \\
\hline ik wilde van opleiding wisselen & 5,6 & 4,6 \\
\hline problemen op de leerwerkplek/stage (bijv. ontslag) & 3,5 & 4,2 \\
\hline ik had problemen met de leraren/schoolleiding & 5,5 & 3,6 \\
\hline ik had een inkomen nodig en ben daarom gaan werken & 5,2 & 3,2 \\
\hline zwangerschap & 2,2 & 2,6 \\
\hline ik ging verhuizen & 1,3 & 1,4 \\
\hline ik had problemen met andere leerlingen & 1,6 & 1,1 \\
\hline verslavingsproblemen & 1,5 & 1,0 \\
\hline in aanraking komen met politie/justitie & 1,7 & 0,9 \\
\hline school in combinatie met zorg voor kinderen, en/of familie was te zwaar & 1,1 & 0,7 \\
\hline ik voelde me niet veilig op school & n.v.t & 0,6 \\
\hline
\end{tabular}


Ondanks de genoemde veranderingen in het instrument vertonen de antwoorden in 20 Io een sterke overeenkomst met die in 2009 . Waar in 2009 de categorie "opleiding voldeed niet aan de verwachtingen" het vaakst werd genoemd als belangrijkste reden, geldt dat ook in 2010 wanneer we hierbij ook de nadere specificaties van deze reden optellen. Ongeveer de helft van de respondenten maakte van de mogelijkheid gebruik om deze reden nader te specificeren, waarbij de meesten de opleiding inhoudelijk ongeschikt $(5,9 \%)$ of slecht georganiseerd $(4,4 \%)$ vonden. Het totale percentage dat aangaf vooral te zijn gestopt omdat de opleiding niet aan de verwachtingen voldeed valt hoger uit in 2010 dan in 2009. Dit was te verwachten, omdat er meer kans is dat iemand zich in een bepaalde reden herkent wanneer de omschrijving hiervan wordt uitgebreid. Het percentage dat vooral is gestopt omdat zij zich niet veilig voelde op school is bijna verwaarloosbaar en heeft daarom vermoedelijk weinig invloed op de overall verdeling van antwoorden. Merkwaardig genoeg is, ondanks de toevoeging van additionele antwoordmogelijkheden, het aandeel dat aangaf vooral gestopt te zijn om een andere reden dan bij de antwoordmogelijkheden weergegeven hoger in 2010 dan in 2009. Verder is de verdeling van antwoorden tamelijk vergelijkbaar in beide jaren.

Net als vorig jaar zijn deze redenen ingedeeld in negen categorieën voor nadere analyse, waarbij de nieuwe reden "ik voelde me niet veilig op school" ingedeeld is in de categorie "problemen op school" (zie bijlage 3.I voor een overzicht van de indeling). Tabel 3.2 geeft een beeld van de relatieve frequentie waarmee de negen typen redenen als belangrijkste werden aangegeven door HAVO/VWO-, VMBO-, BOL- en BBL-schoolverlaters.

Tabel 3.2

Belangrijkste reden voor uitval, naar opleidingstype, $2010(\%)$

\begin{tabular}{lccccccc} 
& $\begin{array}{c}\text { HAVO/ } \\
\text { VWO }\end{array}$ & VMBO & $\begin{array}{c}\text { BOL } \\
\text { niv } 1 / 2\end{array}$ & $\begin{array}{c}\text { BOL } \\
\text { niv } 3 / 4\end{array}$ & $\begin{array}{c}\text { BBL } \\
\text { niv } 1 / 2\end{array}$ & $\begin{array}{c}\text { BBL } \\
\text { niv } 3 / 4\end{array}$ & Totaal \\
\hline Verkeerde opleidingskeuze & 14,1 & 12,8 & 22,9 & 39,1 & 23,4 & 31,7 & 26,1 \\
\hline (Geestelijke) gezondheid & 21,7 & 22,8 & 17,5 & 16,4 & 9,2 & 20,1 & 17,2 \\
\hline Arbeidsmarkt & 5,8 & 5,5 & 16,8 & 12,9 & 23,3 & 13,8 & 13,3 \\
\hline Problemen op school & 5,4 & 15,5 & 9,1 & 7,1 & 13,7 & 9,8 & 10,1 \\
\hline Persoonlijke problemen & 6,3 & 10,9 & 11,4 & 4,6 & 5,6 & 2,6 & 7,1 \\
\hline Opleiding te zwaar & 13,7 & 5,3 & 3,5 & 3,2 & 6,2 & 2,6 & 5,1 \\
Zorgtaken & 1,4 & 1,5 & 4,5 & 4,3 & 3,5 & 2,6 & 3,3 \\
Verhuizing & 2,2 & 4,2 & 1,5 & 0,2 & 0,0 & 0,0 & 1,3 \\
\hline Andere reden & 29,5 & 21,5 & 12,9 & 12,3 & 15,0 & 16,7 & 16,4
\end{tabular}

De redenen zijn gesorteerd naar de frequentie waarmee ze genoemd zijn door alle groepen samen. Om een vergelijking tussen de typen opleidingen te vergemakkelijken zijn de drie vaakst genoemde redenen (behalve "andere reden") donker gemarkeerd. Het patroon is nagenoeg identiek met dat van 2009, zoals in het rapport Voortijdige schoolverlaters: Aanleiding en gevolgen (ROA, 20IO) is beschreven. Vaakst genoemd over de hele linie zijn: "een verkeerde opleidingskeuze", "de (geestelijke) gezondheid" en "de aantrekkingskracht van de arbeidsmarkt". Dit verschilt enigszins naar onderwijssoort. Voor schoolverlaters van HAVO/VWO en VMBO speelt de aantrekkingskracht van de arbeidsmarkt een minder belangrijke rol. Veel belangrijker bij HAVO/VWO is dat de opleiding te zwaar werd gevonden, terwijl relatief veel 
VMBO'ers aangaven dat ze vooral vanwege problemen op school zijn gestopt. Deze laatste reden was ook relatief belangrijk voor schoolverlaters van BBL niveau I/2. Nadere analyses (hier niet gepresenteerd) laten zien dat het hierbij vooral om problemen op de leerwerkplek of stage ging. Deze groep schoolverlaters is overigens minder vaak dan andere schoolverlaters gestopt vanwege (geestelijke) gezondheidsproblemen.

Bovenstaande typologie is gebaseerd op de gedachte dat bepaalde redenen verwant zijn aan elkaar en soms met elkaar samenhangen. Dit uit zich in het feit dat de onderliggende redenen van elke categorie vaak sterk met elkaar zijn gecorreleerd als we kijken naar de mate waarin ze een belangrijke rol hebben gespeeld bij de beslissing om te stoppen. Het is echter ook interessant om te kijken naar de mate waarin bepaalde redenen worden genoemd in combinatie met redenen die bij andere categorieën behoren. Dit kan beleidsconsequenties tot gevolg hebben, omdat maatregelen die worden ingezet om uitval vanwege een bepaalde hoofdcategorie tegen te gaan, ook effectief kunnen zijn voor het bestrijden van uitval vanwege andere redenen. Om een eerste indicatie te geven van de mate waarin schoolverlaters om meer dan één reden met hun opleiding zijn gestopt, staat in figuur 3.I een overzicht van het aantal redenen waarbij schoolverlaters het antwoord 4 of 5 hebben aangekruist, met andere woorden het aantal redenen dat een belangrijke dan wel heel belangrijke rol heeft gespeeld.

\section{Figuur 3.1}

Aantal redenen dat een (heel) belangrijke rol heeft gespeeld bij het besluit om met de opleiding te stoppen $(\%)$

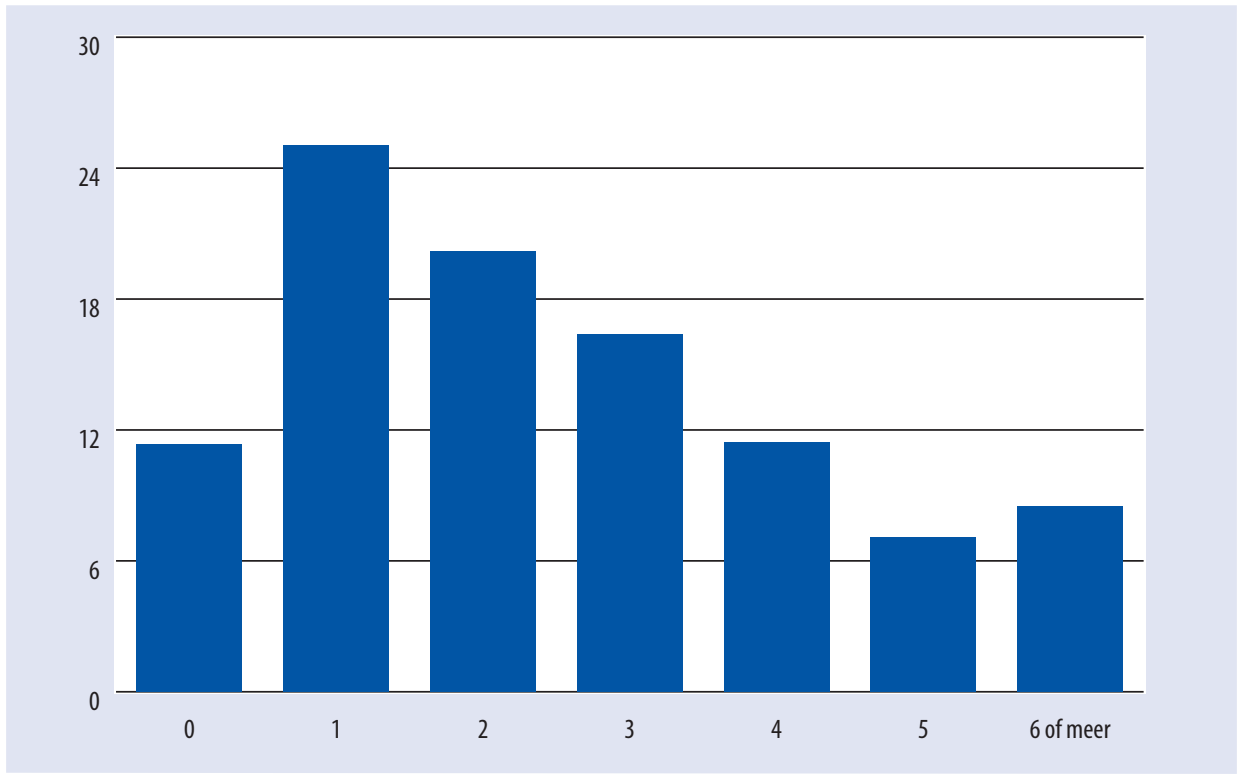

Ruim één op de tien schoolverlaters heeft geen enkele reden genoemd die een belangrijke of heel belangrijke rol heeft gepeeld bij het besluit om voortijdig uit de opleiding te stappen. Dit kan een indicatie zijn dat deze schoolverlaters geen groot gewicht hechtten aan het besluit om wel of niet te stoppen met studeren. Ongeveer een kwart gaf aan dat er voor hen slechts één reden was die echt zwaar woog bij het besluit om te stoppen. Voor één op de vijf gold dat er 
twee belangrijke redenen waren, terwijl nog eens één op de zes aangaf dat er drie belangrijke redenen waren. De resterende groep - iets meer dan een kwart van alle schoolverlaters in het bestand - gaf aan dat er vier, vijf of zelfs zes of meer belangrijke redenen waren om te stoppen.

Om zicht te krijgen op hoe deze redenen met elkaar samenhangen geeft tabel 3.3 per belangrijkste reden het aandeel schoolverlaters weer dat aangaf dat elk van de afzonderlijke redenen een belangrijke rol heeft gespeeld. Met het oog op de overzichtelijkheid zijn de redenen geordend naar hoofdcategorie.

Op de diagonaal (donker gemarkeerd) staat het percentage dat aangaf dat de reden die als belangrijkste werd aangemerkt daadwerkelijk een (heel) belangrijke rol heeft gespeeld. Zoals zou mogen worden verwacht is zonder uitzondering dezelfde reden het vaakst als (heel) belangrijk genoemd. Dit is echter in geen enkel geval Ioo\%, en in een aantal gevallen wordt dezelfde reden slechts door ongeveer tweederde van de schoolverlaters genoemd. Dit lijkt een indicatie te zijn dat sommige schoolverlaters om heel diverse redenen zijn gestopt, waarvan geen enkele reden heel prominent is.

De redenen die tot dezelfde hoofdcategorie behoren als de hoofdreden worden lichter gemarkeerd. Vaak worden deze redenen ook als belangrijk genoemd in combinatie met de hoofdcategorie. Ook dit is weinig verrassend. Hiernaast worden echter ook soms redenen genoemd die tot een heel andere categorie behoren. Om dit te visualiseren is een kadertje gezet om cellen waarbij meer dan een kwart van de betreffende groep schoolverlaters een reden (heel) belangrijk noemde. Een aantal dingen valt hierbij op. Ten eerste wordt bij een aantal van de belangrijkste redenen relatief vaak de "anders" categorie als belangrijk genoemd. Uit de specificatie van de "anders" categorie blijkt dat het hierbij veelal ging om een nadere uitleg van de betreffende reden, bijvoorbeeld dat problemen met andere leerlingen zich uitten in pestgedrag. Dit geldt vooral voor de redenen "opleiding voldeed niet aan mijn verwachtingen" (ondanks de toevoeging van een nadere specificatie), "problemen op de leerwerkplek/stage", "problemen met de leraren/schoolleiding" en "problemen met andere leerlingen".

Een andere opvallende uitkomst is dat relatief veel ex-leerlingen die vaak vanwege arbeidsmarktgerelateerde redenen zijn gestopt, ook aangaven dat de opleiding niet aan de verwachtingen voldeed. Vanuit beleidsperspectief is dit een uitermate belangrijke bevinding, omdat het erop lijkt te wijzen dat er naast de "pull" vanuit de arbeidsmarkt, bij veel van deze schoolverlaters sprake is van een zekere "push" vanuit de opleiding. Dit zou betekenen dat onvrede hun beslissing heeft beïnvloed. Dit suggereert dat er een mogelijkheid bestaat dat de uitval vanwege arbeidsmarktgerelateerde redenen ook kan worden bestreden met betere voorlichting vooraf en wellicht ook door betere ondersteuning bij het vinden van een geschikt alternatief. Dit geldt tot op zekere hoogte ook voor de kleinere groep ex-leerlingen die vooral in verband met zorgtaken is gestopt. 


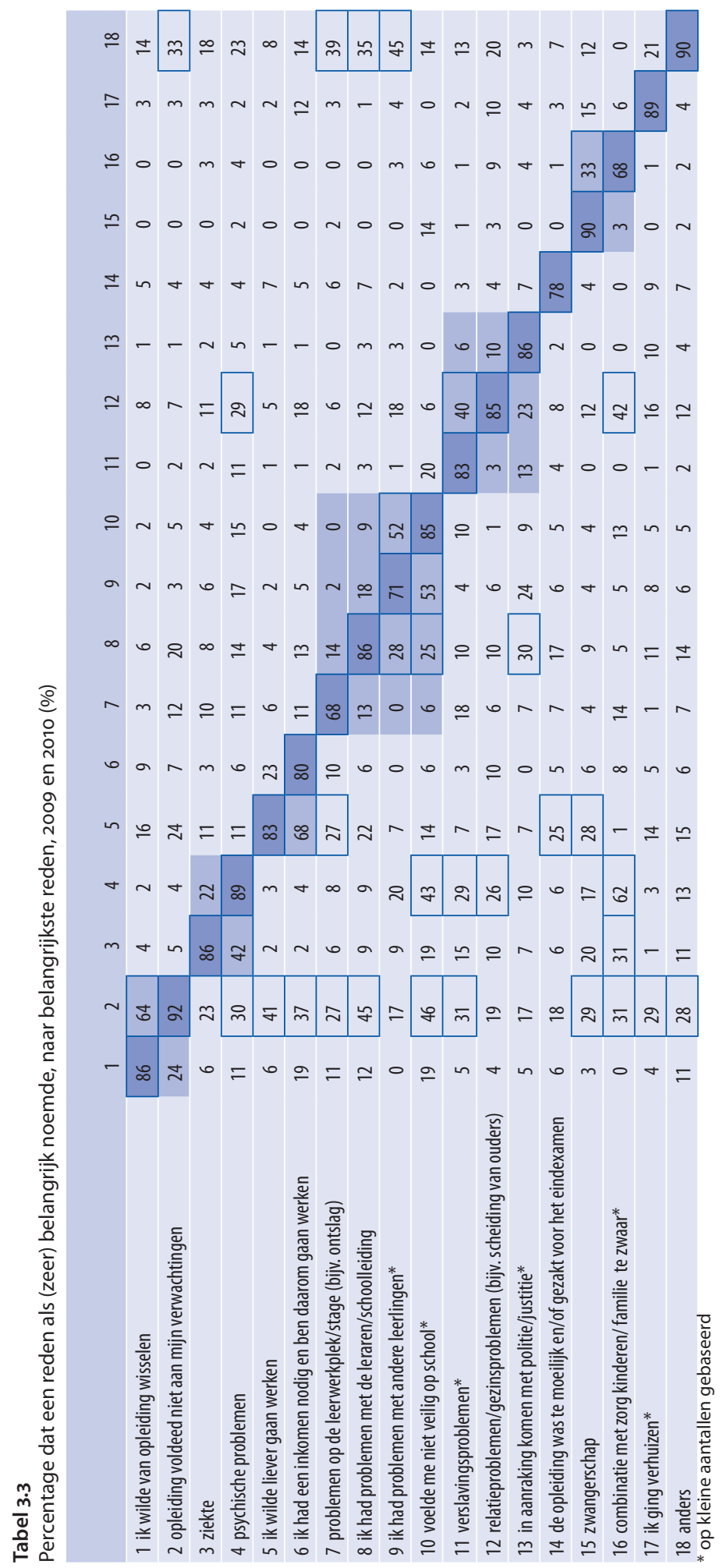


Ook veel schoolverlaters die vooral vanwege problemen op school zijn gestopt geven aan dat de opleiding niet aan de verwachtingen heeft voldaan. Ook dit heeft potentiële beleidsimplicaties, hoewel misschien nader onderzoek nodig is om uit te wijzen hoe deze redenen precies met elkaar samenhangen. Het is niet ondenkbaar dat een deel van de problemen op school hun oorzaak vinden in - of in elk geval verergerd worden door - de constatering dat men niet op de goede plek zit qua opleiding. Indien dit het geval is zou betere voorlichting en/of tijdige ondersteuning uitkomst kunnen bieden.

In vergelijking met 2009 is een groter aantal voortijdige schoolverlaters benaderd met het verzoek om aan het onderzoek mee te doen. ${ }^{16}$ De grotere aantallen respondenten die hiervan het gevolg zijn, stellen ons in staat om iets dieper te graven dan vorig jaar in termen van een nadere vergelijking tussen deelgroepen. We kijken nu naar verschillen binnen brede opleidingstypen (waarbij het onderscheid tussen BOL en BBL voor het $\mathrm{MBO}$ achterwege is gelaten) naar geslacht, etnische groep, en regio (de grote steden (Utrecht, Amsterdam, Den Haag en Rotterdam) versus de rest van Nederland). Alvorens de redenen per deelgroep te analyseren, laten we in tabel 3.4 de verdeling en omvang van de voortijdige schoolverlaters per deelgroepen zien. De beschikbare bestanden omvatten in totaal 31.836 voortijdige schoolverlaters zonder diploma'. Dit aantal is kleiner dan het totaal aantal voortijdige schoolverlaters (4I.785 VSV-ers) van het schooljaar 2008-2009. Reden hiervoor is dat in tabel 3.4 alleen VSV-ers zijn opgenomen die de laatstgevolgde opleiding zonder diploma hebben verlaten. De groep VSV-ers die het onderwijs rechtstreeks na het behalen van een VMBO-diploma dan wel een MBO niveau I diploma hebben verlaten, zijn in tabel 3.4 niet vermeld.

\section{Tabel 3.4}

Verdeling respondenten over deelgroepen, 2009 en 2010 (\%)

\begin{tabular}{lrr} 
& Aantal & $\%$ \\
\hline HAVO/NWO & 31.836 & 100 \\
\hline VMBO & 2.877 & 9 \\
\hline MBO $1 / 2$ & 5.333 & 17 \\
\hline MBO $3 / 4$ & 11.413 & 36 \\
\hline Geslacht & 12.213 & 38 \\
\hline man & & 60 \\
\hline vrouw & 19.102 & 40 \\
\hline Etniciteit & 12.734 & 7 \\
\hline westerse allochtoon & & 26 \\
\hline niet westerse allochtoon & 2.229 & 67 \\
\hline autochtoon & 8.277 & 18 \\
\hline Regio & 21.330 & 82 \\
\hline grote steden (G4) & & \\
\hline rest van Nederland & 5.730 & \\
\hline Bron: DUO; Ministerie van Onderwijs, Cultuur en Wetenschap ; Eigen berekeningen & 26.106 & \\
\hline
\end{tabular}

De cijfers in tabel 3.4 laten zien dat zo'n 3 van de 4 voortijdige schoolverlaters zonder diploma afkomstig zijn van het MBO. De kleinste groep is afkomstig van het HAVO/VWO. Jongens

I6. In 20 Io zijn in totaal Io.890 voortijdige schoolverlaters benaderd, waarvan 2.I34 hebben gerespondeerd. In 2009 ging het om 5.660 benaderde schoolverlaters en 948 respondenten. 
zijn met $60 \%$ duidelijk oververtegenwoordigd en hetzelfde geldt voor niet-westerse allochtonen $(26 \%)$. Tot slot zien we dat bijna een op de vijf voortijdige schoolverlaters afkomstig is van de 4 grote steden.

De volgende tabellen laten zien hoe de redenen om met de opleiding te stoppen verdeeld zijn over deze deelgroepen. Tabel 3.5 laat de uitkomsten naar geslacht zien.

Tabel 3.5

Belangrijkste reden voor uitval, naar geslacht, 2009 en 2010 (\%)

\begin{tabular}{|lcccccccc} 
& \multicolumn{2}{c}{ HAVO/VW0 } & \multicolumn{2}{c}{ VMBO } & \multicolumn{2}{c}{ BOL-BBL $1 / 2$} & \multicolumn{2}{c}{ BOL-BBL 3/4 } \\
\hline & man & vrouw & man & vrouw & man & vrouw & man & vrouw \\
\hline Verkeerde opleidingskeuze & 16,4 & 11,9 & 14,9 & 10,1 & 27,3 & 18,8 & 42,8 & 34,7 \\
\hline (Geestelijke) gezondheid & 17,1 & 26,0 & 18,8 & 28,0 & 8,4 & 18,2 & 11,4 & 20,8 \\
\hline Arbeidsmarkt & 7,0 & 4,6 & 7,2 & 3,3 & 21,8 & 18,3 & 15,1 & 11,5 \\
\hline Problemen op school & 4,3 & 6,4 & 16,8 & 13,9 & 14,1 & 8,7 & 9,1 & 6,3 \\
\hline Persoonlijke problemen & 3,2 & 9,3 & 10,8 & 11,1 & 6,9 & 10,1 & 2,4 & 5,8 \\
\hline Opleiding te zwaar & 16,9 & 10,6 & 6,3 & 3,9 & 7,2 & 2,5 & 3,1 & 3,1 \\
\hline Zorgtaken & 1,8 & 1,0 & 0,5 & 2,7 & 0,5 & 7,7 & 0,8 & 6,5 \\
\hline Verhuizing & 1,7 & 2,7 & 3,2 & 5,6 & 0,0 & 1,5 & 0,2 & 0,1 \\
\hline Andere reden & 31,5 & 27,6 & 21,5 & 21,4 & 13,8 & 14,2 & 15,3 & 11,1 \\
\hline
\end{tabular}

Over de hele linie zijn mannen veel vaker dan vrouwen gestopt vanwege een verkeerde opleidingskeuze of om arbeidsmarktoverwegingen. Vrouwen zijn veel vaker dan mannen gestopt vanwege (geestelijke) gezondheidsproblemen, en vooral bij BOL en BBL om zorgtaken te verrichten. Vrouwen zijn ook vaker gestopt vanwege persoonlijke problemen, hoewel het verschil ten opzichte van mannen klein is bij VMBO. Behalve bij MBO 3/4 zijn mannen vaker dan vrouwen gestopt vanwege een te zware opleiding.

Tabel 3.6 geeft de belangrijkste redenen weer voor allochtonen (westerse en niet-westerse) versus autochtonen. Ook hier zijn een aantal verschillen te zien, maar anders dan voor geslacht zijn deze vaak specifiek voor bepaalde opleidingstypen. Zo zijn westerse allochtonen bij de opleidingstypen BOL en BBL veel vaker dan autochtonen gestopt vanwege (geestelijke) gezondheidsproblemen, terwijl bij HAVO/VWO en VMBO het de autochtonen zijn die het vaakst om deze reden zijn gestopt. Niet-westerse allochtonen bij HAVO/VWO zijn relatief vaak gestopt vanwege arbeidsmarktredenen, problemen op school of persoonlijke problemen, en relatief minder vaak gestopt vanwege een verkeerde opleidingskeuze of een te zware opleiding. Een verkeerde opleidingskeuze was juist relatief vaak de belangrijkste reden om te stoppen voor westerse allochtonen bij VMBO, die minder vaak dan autochtonen van hetzelfde opleidingtype vooral vanwege problemen op school zijn gestopt. Behalve voor niet-westerse allochtonen bij HAVO/VWO waren persoonlijke problemen relatief vaak de belangrijkste reden voor het stoppen voor niet-westerse allochtonen bij VMBO en westerse allochtonen bij $\mathrm{MBO}_{3} / 4$. Westerse allochtonen bij $\mathrm{MBO}$ I/2 noemden relatief vaak problemen op school als belangrijkste reden en aanzienlijk minder vaak de arbeidsmarkt of een te zware opleiding. 


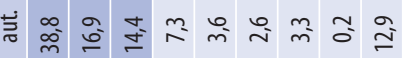

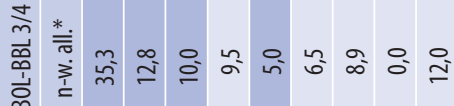

華

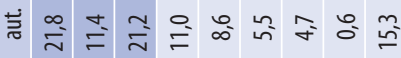

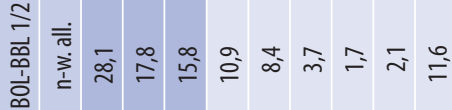

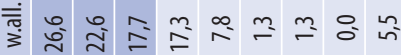

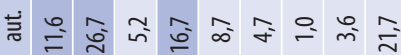

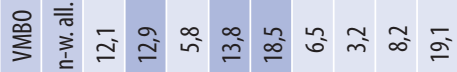

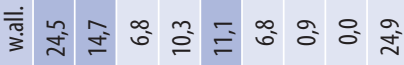

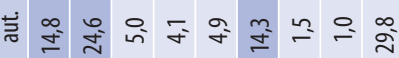

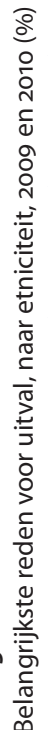

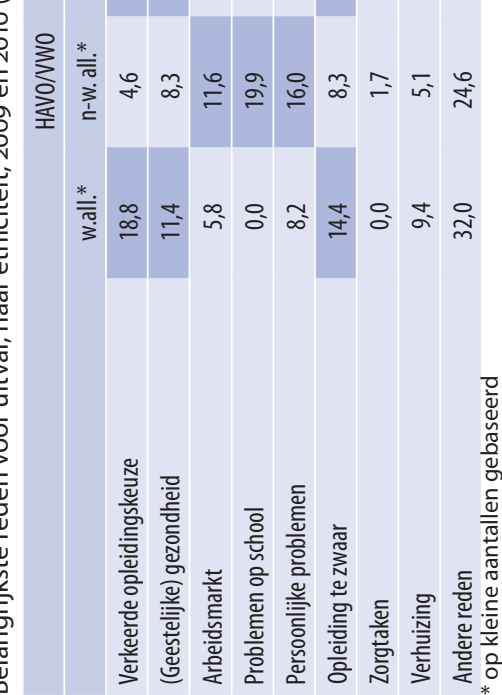


Tabel 3.7

Belangrijkste reden voor uitval, grote steden* vs. rest van Nederland, 2009 en 2010 (\%)

\begin{tabular}{lcccccccc} 
& \multicolumn{2}{c}{ HAVO/VWO } & \multicolumn{2}{c}{ VMBO } & \multicolumn{2}{c}{ BOL-BBL 1/2 } & \multicolumn{2}{c}{ BOL-BBL 3/4 } \\
& g.steden & rest & g.steden & rest & g.steden & rest & g.steden & rest \\
\hline Verkeerde opleidingskeuze & 10,3 & 14,8 & 8,0 & 13,5 & 23,6 & 21,7 & 23,1 & 37,9 \\
\hline (Geestelijke) gezondheid & 17,6 & 22,4 & 19,7 & 23,3 & 12,9 & 14,2 & 13,2 & 16,8 \\
\hline Arbeidsmarkt & 5,7 & 5,8 & 12,8 & 4,4 & 21,7 & 14,8 & 20,1 & 12,2 \\
\hline Problemen op school & 3,4 & 5,7 & 17,3 & 15,3 & 12,5 & 7,9 & 11,4 & 7,7 \\
\hline Persoonlijke problemen & 9,7 & 5,7 & 12,8 & 10,7 & 8,0 & 10,2 & 8,5 & 4,4 \\
\hline Opleiding te zwaar & 15,7 & 13,3 & 5,8 & 5,2 & 4,8 & 5,2 & 4,9 & 3,0 \\
\hline Zorgtaken & 3,5 & 1,0 & 1,1 & 1,5 & 3,5 & 5,6 & 4,0 & 3,6 \\
\hline Verhuizing & 3,4 & 2,0 & 3,5 & 4,3 & 0,9 & 0,4 & 0,8 & 0,2 \\
\hline Andere reden & 30,9 & 29,3 & 18,9 & 21,9 & 12,1 & 20,1 & 14,0 & 14,3 \\
* Utrecht, Amsterdam, Den Haag en Rotterdam & & & & & & & &
\end{tabular}

Er zijn opvallend weinig verschillen tussen de grote steden en de rest van Nederland wat betreft de belangrijkste reden om te stoppen (zie tabel 3.7). Behalve bij MBO I/2 zijn schoolverlaters in de grote steden iets minder vaak dan hun studiegenoten in de rest van het land gestopt vanwege een verkeerde opleidingskeuze of vanwege (geestelijke) gezondheidsproblemen. Behalve bij HAVO/VWO speelt de arbeidsmarkt opvallend vaak een rol bij schoolverlaters uit de grote steden in vergelijking met de rest van Nederland. Voor de rest zijn de verschillen gering.

\subsection{In hoeverre zijn er veranderingen in de tijd?}

Hoewel het instrument en de opzet van het onderzoek in de loop der tijd veranderd zijn, is het toch mogelijk bovenstaande indeling grotendeels te reconstrueren voor de uitvoeringsjaren $2007 \mathrm{t} / \mathrm{m} 2010$ (zie bijlage 3.I). Een uitzondering hierop wordt gevormd door de categorie "opleiding te zwaar", die in 2007 in geen enkele vorm terug te vinden is in de lijst met redenen. Daarnaast kunnen natuurlijk de veranderingen in de vraagstelling en aanpak tot een vertekening leiden, waardoor een verschil tussen twee opeenvolgende jaren zowel het gevolg kan zijn van een verandering in onderzoeksmethodologie als een feitelijke verandering in de grondredenen voor voortijdig schoolverlaten. Er zijn echter twee redenen om toch naar trends te kijken. Ten eerste zijn de veranderingen tussen 2009 en 2010 gering, met uitzondering van de hierboven besproken uitsplitsing van de reden "de opleiding voldeed niet aan mijn verwachtingen”. Rekening houdend met dit verschil lijkt een vergelijking tussen deze twee jaren derhalve verantwoord. Omdat wordt verwacht dat eventuele effecten van de financiële crisis zich vooral in de meting van 20 Io zullen manifesteren lijkt deze vergelijking uitermate interessant. Ten tweede geldt elke verandering in methodologie voor alle deelpopulaties. Dit betekent dat, zelfs wanneer we enige terughoudendheid in acht nemen bij de interpretatie van de absolute verdeling per jaar, een vergelijking van de relatieve verschuiving tussen deelpopulaties - opleidingstypen, mannen versus vrouwen, etnische groepen en grote steden versus de rest van Nederland - zeer informatief kan zijn. Na eerst in tabel 3.8 de verschuiving voor de hele groep voortijdige schoolverlaters te hebben bekeken, zullen we nu de trends per deelpopulatie met elkaar vergelijken. 
Tabel 3.8

Belangrijkste reden voor uitval, 2007-2010 (\%)

\begin{tabular}{|lcccc|} 
& 2007 & 2008 & 2009 & 2010 \\
\hline Verkeerde opleidingskeuze') & 43,6 & 51,9 & 29,3 & 33,8 \\
\hline (Geestelijke) gezondheid & 9,6 & 5,1 & 21,6 & 19,3 \\
\hline Arbeidsmarkt & 26,2 & 16,9 & 17,2 & 14,3 \\
\hline Problemen op school & 3,6 & 7,7 & 12,4 & 11,7 \\
\hline Persoonlijke problemen & 11,7 & 9,3 & 8,6 & 8,4 \\
\hline Opleiding te zwaar & n.v.t. & 6,1 & 5,6 & 6,7 \\
\hline Zorgtaken & 2,7 & 1,9 & 3,9 & 4,1 \\
\hline Verhuizing & 2,5 & 1,1 & 1,5 & 1,7 \\
\hline * categorie 'anders' buiten beschouwing gelaten, 1) verandering in vraagstelling tussen 2008 en 2009 &
\end{tabular}

Meest opvallend is de afname tussen 2008 en 2009 in het percentage dat vooral gestopt is vanwege een verkeerde opleidingskeuze. Dit is vrijwel zeker het gevolg van een verandering in de vraagstelling. Waar dit vanaf 2009 in de lijst met redenen is opgenomen, werd dit in 2007 en 2008 voorafgaand aan deze lijst als aparte vraag gesteld: "Heb je de opleiding verlaten omdat je een andere opleiding wilde gaan volgen?". Mensen die deze vraag bevestigend hebben beantwoord zijn meteen doorverwezen naar een andere vraag, en kregen de lijst met redenen niet voorgelegd. Het laat zich raden dat op zijn minst een deel van de mensen die "ja" op deze vraag hebben geantwoord, een andere reden zou hebben aangekruist als belangrijkste reden als ze daartoe de mogelijkheid zou hebben gekregen. Daarnaast dient opgemerkt te worden dat de antwoordmogelijkheid die vanaf 2009 in de lijst met redenen is opgenomen iets anders geformuleerd is dan de in 2007 en 2008 apart gestelde vraag, namelijk "ik wilde van opleiding wisselen". De lichte toename tussen 2009 en 2010 in het aandeel van deze categorie ligt vermoedelijk aan de bovengenoemde nadere specificatie van het antwoord "de opleiding voldeed niet aan mijn verwachtingen". Vanwege deze veranderingen is het helaas moeilijk, zo niet onmogelijk, om inhoudelijk iets te kunnen zeggen over een eventuele algemene trend wat betreft deze antwoordcategorie.

Een verandering in het instrument veroorzaakt waarschijnlijk ook de andere opvallende verschuiving in tabel 3.7, ook tussen 2008 en 2009, namelijk de toename in het andeel dat (geestelijke) gezondheidsproblemen als reden heeft aangekruist. Vanaf 2009 is het item "vanwege ziekte was het niet mogelijk de opleiding af te maken" vervangen door twee items: "ziekte" en "psychische problemen". Het ontbreken van een expliciete psychische component in combinatie met de nadere restrictie dat door de ziekte het letterlijk onmogelijk was geworden om de opleiding af te maken is hoogstwaarschijnlijk de reden voor deze verandering. Ook voor de categorie "problemen op school" geldt iets soortgelijks: elk jaar is immers een item aan de lijst toegevoegd.

Hoewel deze veranderingen een algemene vergelijking over de volledige periode bemoeilijken, is zoals gezegd met uitzondering van de genoemde nadere specificatie van de antwoordmogelijkheid "de opleiding voldeed niet aan mijn verwachtingen" weinig veranderd in het instrument tussen 2009 en 20IO. Daarom lijkt een vergelijking tussen die twee jaren verantwoord. Het enige andere verschil van betekenis in deze periode betreft een lichte afname van het percentage dat vanwege arbeidsmarktgerelateerde redenen is gestopt, van ongeveer $17 \%$ naar 
I4\%. Het is aannemelijk dat dit verschil te maken heeft gehad met de financiële crisis, waardoor het minder aantrekkelijk is geworden om de arbeidsmarkt te betreden.

We kunnen meer leren over deze veranderingen door bepaalde deelpopulaties met elkaar te vergelijken. Hoewel het gebruikte instrument in de tijd wat veranderd is, gelden deze veranderingen gelijk voor alle deelpopulaties. Een vergelijking in de trends tussen deelpopulaties kan daarom heel leerzaam zijn, omdat een verandering die in sterkere mate optreedt in de ene deelpopulatie dan in een andere hoogstwaarschijnlijk op een reëel verschil duidt. Om te beginnen zijn in tabel 3.9 de trends uitgesplitst naar opleidingstype.

Tabel 3.9

Belangrijkste reden voor uitval, naar opleidingstype, 2007-2010 (\%)

\begin{tabular}{|c|c|c|c|c|}
\hline & $2007^{*}$ & 2008 & 2009 & 2010 \\
\hline \multicolumn{5}{|l|}{ HAVO/VWO } \\
\hline Verkeerde opleidingskeuze ${ }^{1)}$ & 46,5 & 57,2 & 19,5 & 20,2 \\
\hline (Geestelijke) gezondheid & 5,8 & 2,9 & 34,4 & 27,7 \\
\hline Arbeidsmarkt & 12,6 & 5,0 & 8,9 & 6,3 \\
\hline Problemen op school & 0,0 & 3,0 & 4,4 & 11,9 \\
\hline Persoonlijke problemen & 33,5 & 12,3 & 9,6 & 7,4 \\
\hline Opleiding te zwaar & n.v.t. & 17,6 & 18,6 & 20,3 \\
\hline Zorgtaken & 0,0 & 0,0 & 2,7 & 1,1 \\
\hline Verhuizing & 1,6 & 1,9 & 1,8 & 5,0 \\
\hline \multicolumn{5}{|l|}{ VMBO } \\
\hline Verkeerde opleidingskeuze ${ }^{1)}$ & 36,7 & 38,6 & 16,4 & 16,0 \\
\hline (Geestelijke) gezondheid & 6,6 & 8,0 & 30,4 & 26,5 \\
\hline Arbeidsmarkt & 24,0 & 9,5 & 8,2 & 4,6 \\
\hline Problemen op school & 9,7 & 8,6 & 19,3 & 20,6 \\
\hline Persoonlijke problemen & 17,3 & 17,8 & 12,6 & 16,5 \\
\hline Opleiding te zwaar & n.v.t. & 13,1 & 7,2 & 5,7 \\
\hline Zorgtaken & 0,5 & 1,8 & 1,0 & 3,6 \\
\hline Verhuizing & 5,1 & 2,7 & 4,8 & 6,5 \\
\hline \multicolumn{5}{|l|}{ BOL } \\
\hline Verkeerde opleidingskeuze ${ }^{1)}$ & 52,5 & 57,6 & 36,1 & 41,7 \\
\hline (Geestelijke) gezondheid & 8,4 & 5,1 & 18,4 & 20,1 \\
\hline Arbeidsmarkt & 21,9 & 14,9 & 19,0 & 12,6 \\
\hline Problemen op school & 3,7 & 6,8 & 9,5 & 8,1 \\
\hline Persoonlijke problemen & 9,4 & 8,9 & 7,9 & 7,8 \\
\hline Opleiding te zwaar & n.v.t. & 4,0 & 3,3 & 4,3 \\
\hline Zorgtaken & 2,5 & 1,9 & 5,2 & 4,6 \\
\hline Verhuizing & 1,6 & 0,9 & 0,7 & 0,8 \\
\hline \multicolumn{5}{|l|}{ BBL } \\
\hline Verkeerde opleidingskeuze ${ }^{1)}$ & 24,0 & 36,1 & 28,4 & 31,3 \\
\hline (Geestelijke) gezondheid & 13,5 & 4,8 & 16,1 & 11,5 \\
\hline Arbeidsmarkt & 37,5 & 30,9 & 24,7 & 25,3 \\
\hline Problemen op school & 2,1 & 12,0 & 16,1 & 14,3 \\
\hline Persoonlijke problemen & 14,6 & 6,4 & 6,2 & 5,5 \\
\hline Opleiding te zwaar & n.v.t. & 6,0 & 4,9 & 7,8 \\
\hline Zorgtaken & 4,2 & 2,8 & 3,7 & 4,1 \\
\hline Verhuizing & 4,2 & 0,8 & 0,0 & 0,0 \\
\hline
\end{tabular}

* De cijfers voor HAVO/VWO zijn op kleine aantallen gebaseerd 1) verandering in vraagstelling tussen 2008 en 2009 
De afname in het aandeel dat tussen 2009 en 2010 om arbeidsmarktredenen met de opleiding is gestopt is vooral sterk bij VMBO en BOL. Er is ook een lichte afname bij HAVO/VWO, maar geen noemenswaardige verandering bij BBL. Opvallend is dat bij BBL, ondanks de veranderingen in het instrument, het aandeel dat vanwege een verkeerde opleidingskeuze is gestopt eerder toe- dan afgenomen is. In tegenstelling tot de andere opleidingstypen lijkt bij VMBO vanaf 2008 sprake te zijn van een afname in het aandeel dat is gestopt omdat ze de opleiding te zwaar vond. Bij HAVO/VWO is in dezelfde periode een vrij sterke afname van het aandeel dat vanwege persoonlijke problemen is gestopt. De sterke toename tussen 2008 en 2009 in het aandeel dat vanwege (geestelijke) gezondheidsproblemen uit de opleiding is gestapt geldt vooral voor HAVO/VWO en VMBO. Vermoedelijk spelen daar psychische problemen veel vaker een rol dan bij BOL en BBL.

Tabel 3.10

Belangrijkste reden voor uitval, naar geslacht, 2007-2010 (\%)

\begin{tabular}{|lcccc|}
\hline & 2007 & 2008 & 2009 & 2010 \\
\hline Mannen & & & & \\
\hline Verkeerde opleidingskeuze 1) & 44,5 & 54,3 & 34,7 & 35,4 \\
\hline (Geestelijke) gezondheid & 4,8 & 3,2 & 15,9 & 14,1 \\
\hline Arbeidsmarkt & 31,3 & 20,7 & 18,3 & 18,0 \\
\hline Problemen op school & 5,0 & 7,1 & 15,1 & 14,1 \\
\hline Persoonlijke problemen & 11,1 & 6,4 & 6,7 & 7,7 \\
\hline Opleiding te zwaar & n.v.t. & 6,0 & 7,3 & 8,7 \\
\hline Zorgtaken & 2,2 & 1,0 & 1,0 & 0,6 \\
\hline Verhuizing & 1,1 & 1,3 & 1,0 & 1,2 \\
\hline Vrouwen & & & & \\
\hline Verkeerde opleidingskeuze 1) & 42,7 & 49,5 & 24,5 & 32,3 \\
\hline (Geestelijke) gezondheid & 15,0 & 7,0 & 26,7 & 24,0 \\
\hline Arbeidsmarkt & 20,4 & 13,1 & 16,1 & 11,0 \\
\hline Problemen op school & 2,0 & 8,2 & 10,0 & 9,5 \\
\hline Persoonlijke problemen & 12,4 & 12,2 & 10,4 & 9,1 \\
\hline Opleiding te zwaar & n.v.t. & 6,2 & 4,0 & 4,9 \\
\hline Zorgtaken & 3,4 & 2,8 & 6,5 & 7,2 \\
\hline Verhuizing & 4,1 & 1,0 & 1,9 & 2,1 \\
\hline 1) verandering in vraagstelling tussen 2008 en & & & \\
\hline
\end{tabular}

Tabel 3.IO toont de trends naar geslacht. Opmerkelijk is dat vrouwen veel sterker op de financiële crisis lijken te hebben gereageerd dan mannen. Het aandeel vrouwen dat gestopt is om naar de arbeidsmarkt te gaan is namelijk sterk gedaald tussen 2009 en 20IO, terwijl dit aandeel bij mannen min of meer gelijk is gebleven. In de jaren daarvoor is dit aandeel juist bij mannen fors afgenomen. Ook zijn vrouwen niet alleen veel vaker dan mannen gestopt om zorgtaken te verrichten, dit percentage lijkt in de tijd bij vrouwen enigszins toegenomen te zijn. Wel lijkt bij vrouwen, in tegenstelling tot mannen, het aandeel dat vanwege persoonlijke problemen is gestopt de laatste jaren licht te zijn afgenomen, zodat er op dit punt in 2010 weinig verschil meer bestaat tussen mannen en vrouwen. 
Tabel 3.11

Belangrijkste reden voor uitval, naar etniciteit, 2007-2010* (\%)

\begin{tabular}{|lcccc|}
\hline & 2007 & 2008 & 2009 & 2010 \\
\hline Autochtonen & & & & \\
\hline Verkeerde opleidingskeuze ${ }^{1)}$ & 46,5 & 52,2 & 29,9 & 33,6 \\
\hline (Geestelijke) gezondheid & 10,1 & 4,7 & 21,7 & 20,2 \\
\hline Arbeidsmarkt & 25,1 & 18,0 & 18,2 & 15,5 \\
\hline Problemen op school & 3,1 & 7,3 & 12,3 & 11,2 \\
\hline Persoonlijke problemen & 11,6 & 9,7 & 7,8 & 7,1 \\
\hline Opleiding te zwaar & n.v.t. & 5,9 & 5,3 & 7,0 \\
\hline Zorgtaken & 2,3 & 1,3 & 3,8 & 4,0 \\
\hline Verhuizing & 1,3 & 0,8 & 1,0 & 1,4 \\
\hline Niet-westerse allochtonen & & & 26,5 & 32,2 \\
\hline Verkeerde opleidingskeuze ${ }^{1)}$ & 39,8 & 49,4 & 17,6 & 15,5 \\
\hline (Geestelijke) gezondheid & 7,8 & 8,3 & 15,1 & 9,9 \\
\hline Arbeidsmarkt & 29,3 & 12,0 & 14,8 & 12,5 \\
\hline Problemen op school & 3,5 & 7,5 & 10,5 & 14,7 \\
\hline Persoonlijke problemen & 9,8 & 9,5 & 6,6 & 6,5 \\
\hline Opleiding te zwaar & n.v.t. & 8,8 & 5,0 & 5,3 \\
\hline Zorgtaken & 4,6 & 2,5 & 4,0 & 3,4 \\
\hline Verhuizing & 5,2 & 1,9 & 2009 & \\
* onvoldoende celvulling bij westerse allochtonen, 1) verandering in vraagstelling tussen 2008 en & & \\
\hline
\end{tabular}

Tabel 3.II laat de trends zien voor niet-westerse allochtonen versus autochtonen. Opmerkelijk is dat niet-westerse allochtonen veel sterker op de financiële crisis lijken te hebben gereageerd dan autochtonen. Dit blijkt uit de forse afname van het aandeel "arbeidsmarkt" onder de niet-westerse allochtonen. Verder is bij deze groep een beduidend minder sterke toename te zien in het aandeel dat gestopt is door "geestelijke gezondheid" tussen 2008 en 2009 dan bij autochtonen. Wel neemt het aandeel dat vanwege persoonlijke problemen is gestopt tussen 2009 en 20 Io tamelijk sterk toe bij niet-westerse allochtonen.

Uit tabel 3.I2 blijkt dat er weinig verschil is tussen de grote steden en de rest van Nederland, niet alleen in de verdeling van de belangrijkste redenen voor uitval, maar ook in de trends in deze redenen in de tijd. Schoolverlaters in de grote steden lijken iets meer op de crisis te hebben gereageerd, in de zin dat het aandeel "arbeidsmarkt" alleen licht is afgenomen in de grote steden. Dit aandeel lag ook in 2008 beduidend lager dan in de rest van Nederland. Het aandeel "problemen op school" is in 2009 fors toegenomen in de grote steden maar niet in de rest van Nederland. Dat de verschillen in redenen tussen de grote steden en de rest van Nederland klein zijn is opmerkelijk, gezien het feit dat uitval als zodanig in de grote steden veel hoger ligt dan in de rest van Nederland (Ministerie van OC\&W, 20IO). 
Tabel 3.12

Belangrijkste reden voor uitval, grote steden vs de rest van Nederland, 2007-2010 (\%)

\begin{tabular}{lcccc} 
& 2007 & 2008 & 2009 & 2010 \\
\hline Grote steden & & & & \\
\hline Verkeerde opleidingskeuze 1) & 43,9 & 51,5 & 29,9 & 35,4 \\
(Geestelijke) gezondheid & 6,9 & 5,3 & 20,7 & 17,8 \\
\hline Arbeidsmarkt & 29,6 & 11,3 & 18,8 & 14,4 \\
\hline Problemen op school & 2,2 & 9,5 & 10,4 & 8,8 \\
\hline Persoonlijke problemen & 11,6 & 12,5 & 8,8 & 9,5 \\
\hline Opleiding te zwaar & n.v.t. & 6,9 & 5,3 & 7,0 \\
\hline Zorgtaken & 2,1 & 2,7 & 5,8 & 5,8 \\
\hline Verhuizing & 3,8 & 0,3 & 0,4 & 1,4 \\
\hline Rest van Nederland & & & & 33,3 \\
\hline Verkeerde opleidingskeuze 1) & 43,6 & 52,0 & 29,1 & 19,7 \\
\hline (Geestelijke) gezondheid & 10,3 & 5,1 & 21,8 & 14,3 \\
\hline Arbeidsmarkt & 25,4 & 18,5 & 16,7 & 12,6 \\
\hline Problemen op school & 4,0 & 7,1 & 13,0 & 8,1 \\
\hline Persoonlijke problemen & 11,8 & 8,4 & 8,6 & 6,6 \\
\hline Opleiding te zwaar & n.v.t. & 5,8 & 5,7 & 3,6 \\
\hline Zorgtaken & 2,9 & 1,7 & 3,3 & 1,8 \\
\hline Verhuizing & 2,1 & 1,3 & 1,8 & \\
\hline 1) verandering in vraagstelling tussen 2008 en 2009 & & & & \\
\hline
\end{tabular}

\subsection{Analyse van belangrijkste reden}

Zoals reeds eerder vermeld, is in 2010 in vergelijking met 2009 een groter aantal voortijdige schoolverlaters benaderd met het verzoek om aan het onderzoek deel te nemen. De grotere aantallen respondenten die hiervan het gevolg waren, zijn al benut om een nadere vergelijking te maken tussen bepaalde interessante deelgroepen. In deze pararaaf willen we hierop voortbouwen, door middel van een multivariate analyse voor de kans dat men de verschillende redenen als meest belangrijk noemt (een zogenoemde multinomiale logistische regressieanalyse). Hierin kunnen we de effecten van het behoren tot deze deelpopulaties simultaan schatten, waardoor gecorrigeerd kan worden voor eventuele compositie-effecten (bijvoorbeeld het hogere aandeel allochtonen in de grote steden dan in de rest van Nederland). Tevens kan het effect worden geschat van een aantal "vroege signalen" van uitval, zoals spijbelgedrag, gedwongen verlaten van de opleiding en ondersteuning bij het proberen de opleiding af te ronden dan wel om een geschikt alternatief te vinden. Tabel 3.13 vat de belangrijkste resultaten samen. 


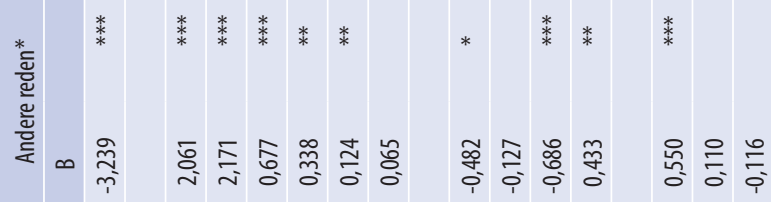

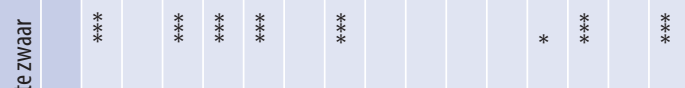

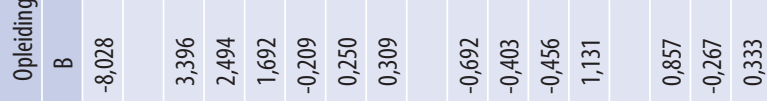

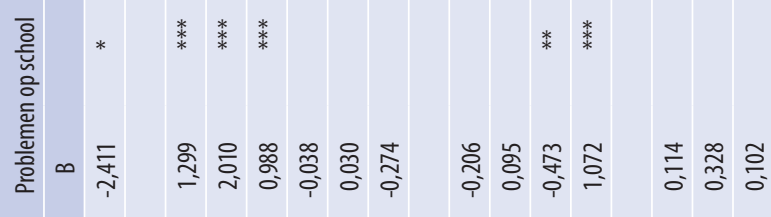

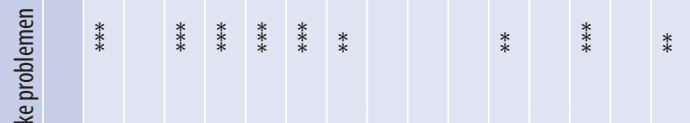

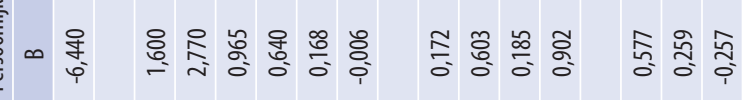

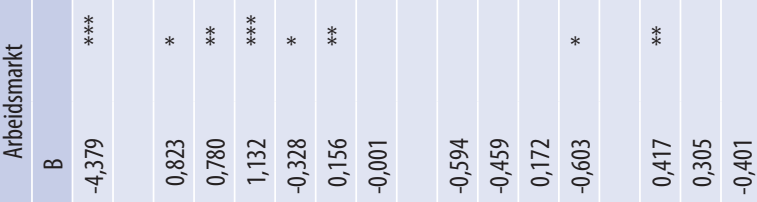

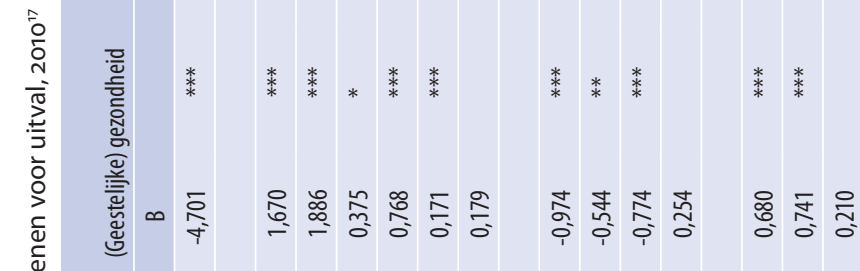

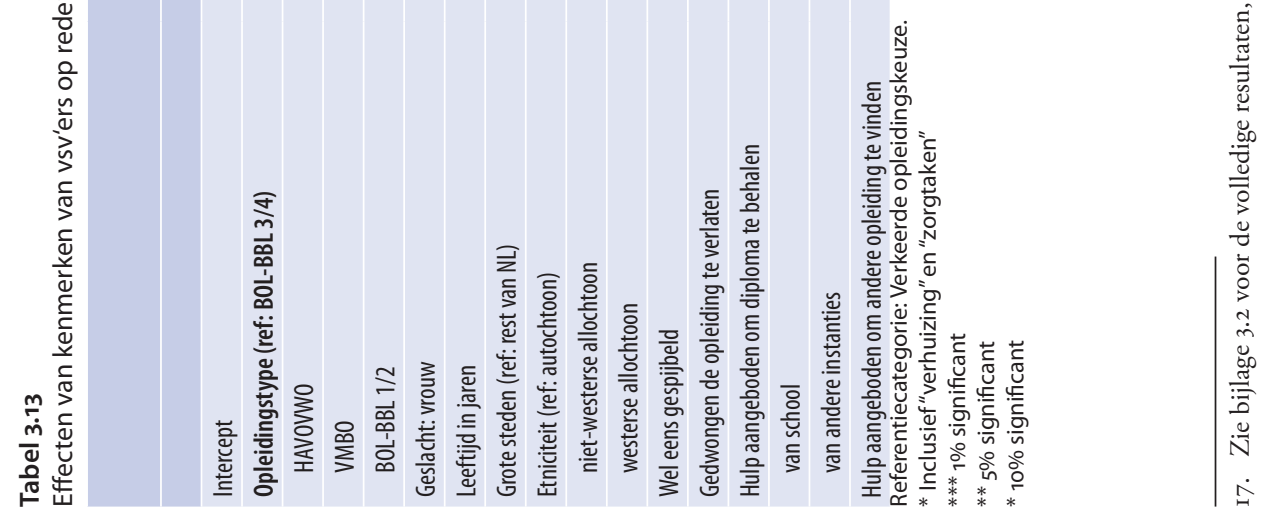


Schoolverlaters van $\mathrm{HAVO} / \mathrm{VWO}, \mathrm{VMBO}$ en $\mathrm{MBO}$ I/2 zijn veel vaker dan $\mathrm{MBO}_{3} / 4$ schoolverlaters gestopt vanwege de in de tabel vermelde redenen. De meeste effecten zijn bovendien statistisch (sterk) significant. Dit betekent dat $\mathrm{MBO}$ 3/4-schoolverlaters juist relatief vaak vanwege een verkeerde opleidingskeuze zijn gestopt. Vrouwen zijn significant vaker dan mannen gestopt vanwege hun (geestelijke) gezondheid of persoonlijke problemen. Oudere schoolverlaters zijn vaker dan jongere schoolverlaters gestopt vanwege de in de tabel vermelde redenen, met uitzondering van problemen op school. Anders gezegd zijn jongere schoolverlaters veel meer geneigd te stoppen als gevolg van zulke problemen op school of vanwege een verkeerde opleidingskeuze. Het beeld dat er weinig verschil bestaat in het patroon van redenen tussen de grote steden en de rest van Nederland wordt door deze analyses nog eens bevestigd: er is geen enkel significant effect van het verlaten van de school in de grote steden. Het enige significante verschil tussen autochtonen en allochtonen is dat niet-westerse allochtonen significant minder vaak dan autochtonen gestopt zijn vanwege problemen met hun geestelijke gezondheid.

Wanneer we kijken naar vroege signalen voor voortijdige uitval, zien we dat deze niet alleen voorspellend zijn voor uitval op zich (ROA, 20IO), maar ook voor de redenen voor zulke uitval. Spijbelaars verlaten de opleiding minder vanwege hun geestelijke gezondheid, problemen op school, een te zware opleiding of een andere reden, en dus juist vaker vanwege een verkeerde opleidingskeuze (de referentiecategorie), persoonlijke problemen, of om naar de arbeidsmarkt te gaan. Gedwongen verlaten van de opleiding gaat relatief vaak gepaard met persoonlijke problemen, problemen op school, een te zware opleiding of een andere reden, en heeft relatief minder te maken met arbeidsmarktoverwegingen. Door de school aangeboden hulp om het diploma te behalen werkt positief op de kans van alle redenen, uitgezonderd problemen op school. Dit suggereert dat zulke hulp de kans op uitval om deze reden, evenals vanwege een verkeerde opleidingskeuze, vermindert. Dergelijke hulp van andere instanties heeft alleen een significant effect op de kans dat men vanwege (geestelijke) gezondheidsproblemen is gestopt. Er is hier vermoedelijk sprake van een omgekeerde causaliteit: mensen met zulke problemen hebben een grotere kans om dergelijke hulp in te schakelen. Er is geen enkel effect van hulp om een andere opleiding te vinden op de reden voor uitval.

\subsection{Terugkeer in het onderwijs}

Uit een recent onderzoek van ECBO (Van Wijk et al., 20I0) komt naar voren dat veel voortijdige schoolverlaters terugkeren in het onderwijs. Op basis van gegevens van DUO blijkt dat in totaal zo'n $37 \%$ van de voortijdige schoolverlaters uit het schooljaar 2005/2006 in de schooljaren 2007/2008, 2008/2009 of 2009/20I0 teruggekeerd zijn. Dit percentage ligt veel hoger bij het VO (bijna de helft) dan bij het MBO (minder dan een derde). Verder laten de auteurs onder meer zien dat ongeveer een op de acht teruggekeerde vsv'ers in de jaren daarna het onderwijs met startkwalificatie heeft verlaten, terwijl ongeveer een kwart opnieuw ongediplomeerd is gestopt. Door koppeling van dezelfde DUO-gegevens met ons 2009 vsv-bestand wordt het mogelijk de terugkeer in het onderwijs in deze paragraaf aan een nadere analyse te onderwerpen. Naast de vraag hoeveel voortijdige schoolverlaters in de jaren daarna teruggekeerd zijn in het onderwijs, kan van de jongeren die wel opnieuw een studie zijn gaan volgen, verder worden vastgesteld wie hiervan inmiddels een diploma heeft behaald, wie dat (nog) niet heeft gedaan maar wel nog in het onderwijs zit, wie inmiddels 
nog eens van opleiding is gewisseld, en tenslotte wie het onderwijs weer zonder diploma heeft verlaten. Omdat er jongeren kunnen zijn die teruggekeerd zijn in het onderwijs maar niet in het DUO-bestand zijn opgenomen - bijvoorbeeld jongeren die in België hun studieloopbaan hebben voortgezet, of jongeren die een Luzac-opleiding zijn gaan volgen - hebben we bij het vaststellen van deze percentages ook rekening gehouden met antwoorden die door onze respondenten zijn gegeven. Tabel 3.I4 geeft een beeld van de eventuele voortzetting van de onderwijsloopbaan van voortijdige schoolverlaters van het cohort 2009.

Tabel 3.14

Eventuele voortzetting van de onderwijsloopbaan, naar opleidingstype, 2009 (\%)

\begin{tabular}{lccrrc|} 
& HAVO/VWO & VMBO & BOL-BBL 1/2 & BOL-BBL 3/4 & Totaal \\
\hline Teruggekeerd, diploma behaald & 31,6 & 12,5 & 4,1 & 7,7 & 9,7 \\
\hline Teruggekeerd, niet gewisseld, nog bezig & 28,8 & 37,1 & 16,2 & 22,0 & 24,1 \\
\hline Teruggekeerd en weer gewisseld, nog bezig & 6,6 & 7,2 & 3,0 & 4,3 & 4,8 \\
\hline Teruggekeerd maar alsnog ongediplomeerd gestopt & 12,4 & 9,3 & 6,0 & 8,7 & 8,3 \\
\hline Niet teruggekeerd in het onderwijs & 20,6 & 34,0 & 70,6 & 57,2 & 53,1 \\
\hline
\end{tabular}

De cijfers in tabel 3.I4 komen in grote lijnen overeen met die uit het rapport van ECBO (Van Wijk et al., 20IO). Doordat we de DUO-gegevens hebben aangevuld met antwoorden uit ons eigen onderzoek, ligt het percentage terugkeerders nog hoger dan in het ECBO-rapport. Rekening houdend met opleidingen die niet in het DUO-bestand worden vermeld, blijkt dat bijna de helft van de voortijdige schoolverlaters in de jaren na het verlaten van hun opleiding terugkeert in het onderwijs. Evenals in het ECBO-rapport, is het percentage terugkeerders vooral hoog bij HAVO/VWO en VMBO, en het laagst bij $\mathrm{MBO}$ I/2. Bijna een derde van HAVO/VWO heeft inmiddels een diploma. Van de andere onderwijstypen zijn verreweg de meeste terugkeerders nog bezig, waarvan een klein deel inmiddels bezig is met weer een nieuwe opleiding.

Het heeft niet zoveel zin om deze percentages te laten zien voor andere deelpopulaties, omdat deze verschillend verdeeld zijn over opleidingstypen en de celvulling te klein is om hier een nadere uitsplitsing naar te maken. Wat wel mogelijk is, is een multivariate analyse waarin het effect van het behoren tot deze deelpopulaties op de kans op een succesvolle terugkeer in het onderwijs wordt geschat. Hierbij kan tevens het effect worden geschat van de redenen voor uitval en de omstandigheden die aan de beslissing om te stoppen voorafgingen. Een succesvolle terugkeer wordt hierbij gedefinieerd als mensen die óf hun diploma inmiddels hebben behaald, óf nog met een opleiding bezig zijn. Tabel 3.15 geeft de resultaten van deze analyses weer. 
Tabel 3.15

Resultaten van een multivariate analyse voor de kans op een succesvolle terugkeer, $2009^{18}$

\begin{tabular}{|c|c|c|}
\hline & B & \\
\hline \multicolumn{3}{|l|}{ Opleidingstype initiële opleiding (ref. BOL-BBL 3/4) } \\
\hline HAVOVWO & 1,085 & *** \\
\hline VMBO & 0,341 & \\
\hline BOL-BBL $1 / 2$ & $-0,624$ & *** \\
\hline Geslacht: vrouw (ref.: mannen) & 0,112 & \\
\hline Leeftijd in jaren & $-0,191$ & *** \\
\hline Grote steden (ref. rest van NL) & $-0,157$ & \\
\hline \multicolumn{3}{|l|}{ Etniciteit (ref: autochtoon) } \\
\hline niet westerse allochtoon & 0,087 & \\
\hline westerse allochtoon & 0,189 & \\
\hline \multicolumn{3}{|c|}{ Belangrijkste reden om te stoppen (ref.: Verkeerde opleidingskeuze) } \\
\hline Verhuizing & $-0,324$ & \\
\hline Zorgtaken & $-1,045$ & * \\
\hline (Geestelijke) gezondheid & $-0,717$ & *** \\
\hline Arbeidsmarkt & $-1,172$ & *** \\
\hline Persoonlijke problemen & $-0,757$ & ** \\
\hline Problemen op school & $-0,818$ & *** \\
\hline Opleiding te zwaar & $-0,211$ & \\
\hline Andere reden & 0,000 & \\
\hline Geen reden genoemd & $-0,465$ & \\
\hline Wel eens gespijbeld & $-0,286$ & * \\
\hline Gedwongen de opleiding te verlaten & 0,367 & * \\
\hline \multicolumn{3}{|l|}{ Hulp aangeboden om diploma te behalen } \\
\hline van school & 0,001 & \\
\hline van andere instanties & $-0,309$ & \\
\hline Hulp aangeboden om andere opleiding te vinden & 0,325 & * \\
\hline Constante & 3,711 & *** \\
\hline
\end{tabular}

Vooral bij HAVO/VWO is de kans op een succesvolle terugkeer hoog. De laagste kans is te zien bij MBO I/2. Er is geen significant verschil naar geslacht, etniciteit of grote steden versus de rest. Er is wel een negatief effect van leeftijd: oudere schoolverlaters hebben een lagere kans op terugkeer, wat tamelijk vanzelfsprekend lijkt.

$\mathrm{Na}$ te hebben gecorrigeerd voor deze kenmerken is een significant verschil te zien tussen de redenen om te stoppen. Als referentiecategorie is gekozen voor de verkeerde opleidingskeuze, omdat dit de reden was waarbij het meest voor de hand liggend is dat men terug zou keren in het onderwijs. Inderdaad zijn op de restcategorie "andere reden" na de coëfficiënten bij alle andere categorieën negatief, hoewel niet altijd statistisch significant. Een succesvolle terugkeer is het minst waarschijnlijk wanneer de belangrijkste reden voor vertrek is om naar de arbeidsmarkt te gaan. Mensen die vanwege zorgverplichtingen zijn gestopt maken ook

I8. Zie bijlage 3.3 voor de volledige resultaten, inclusief standaardfouten. 
zelden een succesvolle terugkeer, hoewel dit effect maar matig significant is vanwege de kleine aantallen. Vertrek vanwege persoonlijke problemen, problemen op school of (geestelijke) gezondheidsproblemen lijkt ook weinig hoop te bieden op een succesvolle terugkeer in het onderwijs, hoewel voor deze groepen nog altijd beduidend meer kans is dan bij mensen die naar de arbeidsmarkt zijn gegaan. Een vertrek vanwege een verhuizing, een te zware opleiding of een andere reden lijkt een succesvolle terugkeer veel minder in de weg te staan.

Er zijn verder nog enkele kleine effecten van de situatie voorafgaande aan het verlaten van de opleiding. Mensen die wel eens hebben gespijbeld hebben iets minder kans op een succesvolle terugkeer in het onderwijs dan mensen die dit nooit hebben gedaan. Mensen die gedwongen zijn om de opleiding te verlaten hebben hier daarentegen juist meer kans op. Dit lijkt misschien vreemd, maar ligt vooral aan het feit dat de meeste van deze mensen gedwongen zijn omdat hun maximale verblijfsduur in de opleiding was bereikt (hoewel nadere analyses uitwijzen dat een gedwongen vertrek vanwege het tegen de regels van de school ingaan een succesvolle terugkeer niet in de weg staat). Hulp die is aangeboden door de school of andere instanties om de initiële opleiding af te maken heeft geen effect op de kans op terugkeer. Tenslotte heeft aangeboden hulp om een nieuwe opleiding te vinden blijkbaar enig effect gehad.

\subsection{Spijt achteraf van de keuze om te stoppen}

Schoolverlaters zijn gevraagd of ze er achteraf spijt van hebben dat ze destijds met de opleiding zijn gestopt. Tabel 3.I6 laat de verdeling van hun antwoorden zien in 2009 en 20I0, naar onderwijssoort. De verdeling van de antwoorden in 2010 lijkt vrij veel op die in 2009, maar er zijn verschillen. In beide jaren geeft een krappe meerderheid aan geen spijt te hebben van het besluit om te met de opleiding te stoppen. Er is echter een lichte verschuiving te zien in redenen waarom men wel spijt heeft. Behalve bij VMBO geven in 2010 minder schoolverlaters aan dat ze achteraf bezien liever niet meer zouden stoppen, en meer schoolverlaters dat ze destijds niet anders konden.

Tabel 3.16

Spijt met keuze om te stoppen, naar onderwijssoort, 2009 en 2010 (\%)

\begin{tabular}{lccccccccccc} 
& \multicolumn{1}{c}{ HAVO/VW0 } & \multicolumn{2}{c}{ VMBO } & & BOL-BBL 1/2 & BOL-BBL 3/4 & \multicolumn{2}{c}{ Totaal } \\
& 2009 & 2010 & 2009 & 2010 & 2009 & 2010 & 2009 & 2010 & 2009 & 2010 \\
\hline geen spijt & 64,0 & 65,4 & 47,9 & 50,9 & 52,6 & 48,5 & 62,7 & 58,0 & 56,1 & 54,5 \\
wel spijt, zou nu niet meer doen & 12,7 & 6,9 & 15,4 & 13,0 & 18,8 & 16,2 & 14,7 & 13,0 & 16,1 & 12,9 \\
wel spijt, maar kon destijds niet anders & 23,3 & 27,7 & 36,6 & 36,1 & 28,6 & 35,4 & 22,6 & 29,0 & 27,8 & 32,6
\end{tabular}

Het rapport van vorig jaar liet zien dat de spijtvraag sterk verschilt naar reden voor uitval. Bijna driekwart van de schoolverlaters die vanwege een verkeerde opleidingkeuze gestopt is, geeft aan geen spijt te hebben van het besluit om te stoppen. Dit geldt voor slechts een kwart van degenen die vanwege persoonlijke problemen zijn gestopt, en ruim een derde van de schoolverlaters die gestopt zijn vanwege een verhuizing of om zorgtaken te verrichten. Van deze groepen geven de meesten die wel spijt hebben aan dat doorgaan met de opleiding geen reële optie was, maar ook een aanzienlijk deel zou het besluit terugdraaien als dat mogelijk 
was. Een analyse van de data (hier niet gepresenteerd) laat eenzelfde patroon zien in 2010. Interessant is om na te gaan of de spijtvraag samenhangt met de vraag of men in het onderwijs is teruggekeerd. Tabel 3.17 laat dit zien voor 2009.

Tabel 3.17

Spijt met keuze om te stoppen, naar terugkeerstatus, 2009 (\%)

\begin{tabular}{lccccc} 
& $\begin{array}{c}\text { Teruggekeerd, } \\
\text { diploma behaald }\end{array}$ & $\begin{array}{c}\text { Teruggekeerd, niet } \\
\text { gewisseld, nog } \\
\text { bezig }\end{array}$ & $\begin{array}{c}\text { Teruggekeerd en } \\
\text { weer gewisseld, nog } \\
\text { bezig }\end{array}$ & $\begin{array}{c}\text { Teruggekeerd } \\
\text { maar alsnog } \\
\text { ongediplomeerd } \\
\text { gestopt }\end{array}$ & $\begin{array}{c}\text { Niet teruggekeerd } \\
\text { in het onderwijs }\end{array}$ \\
\hline $\begin{array}{l}\text { geen spijt } \\
\text { wel spijt, zou nu niet meer } \\
\text { doen }\end{array}$ & 66,1 & 58,5 & 43,2 & 51,8 & 54,7 \\
$\begin{array}{l}\text { wel spijt, maar kon destijds } \\
\text { niet anders }\end{array}$ & 14,2 & 15,3 & 24,8 & 23,9 & 14,8 \\
\hline
\end{tabular}

De jongeren die teruggekeerd zijn in het onderwijs en inmiddels een diploma hebben behaald hebben het minst vaak spijt van hun keuze. Dit lijkt het beeld te bevestigen dat het hier veelal gaat om jongeren die tot het besef waren gekomen dat de destijds gekozen opleiding voor hen niet de beste keuze was, en een weloverwogen keuze makkten om een andere koers te varen. De groep die vaakst spijt heeft van de keuze om te stoppen bestaat uit jongeren die inmiddels weer zijn gewisseld, en die nog bezig zijn met hun opleiding. Deze jongeren geven opvallend vaak aan dat ze achteraf die eerste keuze om te stoppen niet weer zouden maken. Dit lijkt een indicatie te zijn dat het veelal gaat om jongeren die grote moeite hebben om de juiste keuzes te maken. Ook jongeren die teruggekeerd zijn in het onderwijs en inmiddels weer gestopt zijn, geven vaak aan dat ze achteraf die eerste keuze om te stoppen niet weer zouden maken. Bij deze groepen lijkt derhalve enige winst te boeken door betere voorlichting en begeleiding.

\subsection{Discussie en conclusies}

In dit hoofdstuk zijn de redenen waarom jongeren voortijdig het onderwijs verlaten aan een nadere analyse onderworpen. Hierbij zijn vragen aan bod gekomen als: verschillen deze redenen naar geslacht, etniciteit of regio? In hoeverre worden bepaalde redenen in combinatie met elkaar genoemd? Zijn bepaalde redenen meer een voorbode voor een tijdelijke vertrek uit het onderwijs, terwijl andere vaker geassocieerd worden met een meer definitieve afsluiting van de onderwijsloopbaan? De belangrijkste conclusies zijn:

a) Redenen voor voortijdig schoolverlaten

- Redenen blijven stabiel in de tijd: Een verkeerde studiekeuze, de (geestelijke) gezondheid en de aantrekkingskracht van de arbeidsmarkt zijn de belangrijkste drie oorzaken van voortijdig schoolverlaten. Deze redenen vormen in de afgelopen 5 jaren een stabiele "top 3 ".

- De economische crisis heeft weinig invloed op de redenen: de crisis heeft geleid tot een lichte afname van het aandeel dat voornamelijk is gestopt om naar de arbeidsmarkt te gaan, maar in andere opzichten heeft de crisis weinig effect op de redenen gehad. 
- Geen grote steden effect: Er is weinig verschil tussen de grote steden en de rest van Nederland, niet alleen in de verdeling van de belangrijkste redenen voor uitval, maar ook in de trends in deze redenen in de tijd.

- Push- en pull effecten komen vaak samen voor: relatief veel voortijdige schoolverlaters die om arbeidsmarktredenen zijn gestopt (pull effect), vermelden ook dat de opleiding niet aan de verwachtingen voldeed (push effect). Uitval vanwege arbeidsmarktgerelateerde redenen kan dan ook deels worden bestreden met betere voorlichting (ex ante) en ondersteuning (ex post).

b) Terugkeer in het onderwijs

- Voortijdig maar niet voor altijd: bijna $40 \%$ van de jongeren die het onderwijs in het schooljaar 2007/2008 voortijdig heeft verlaten, is in het voorjaar van 201 weer actief in het onderwijs of heeft alweer een diploma in het onderwijs behaald.

- Redenen voor uitval beïnvloeden de kans op terugkeer: Een succesvolle terugkeer is het minst waarschijnlijk wanneer de belangrijkste reden voor vertrek is om naar de arbeidsmarkt te gaan. Jongeren die vanwege zorgverplichting, persoonlijke problemen, problemen op school of (geestelijke) gezondheidsproblemen zijn gestopt maken ook relatief zelden een succesvolle terugkeer. 


\section{Literatuur}

Allen, J. \& R. van der Velden (200I), Educational Mismatches Versus Skill Mismatches: Effects on Wages, Job-Related Training, and On-the-Job Search, Oxford Economic Papers, 3 (200I), pp. 434-452

Allen, J., Coenen, J., Velden van der R.,(2007), Afgestudeerden in het hoger onderwijs in Nederland in vergelijking met andere landen Resultaten van het REFLEX project, Den Haag: Ministerie van OCW.

Cörvers, F., Euwals, R., Grip de, A., (2010), Labour Market Flexibility in the Netherlands. The role of contracts and self-employment, CPB Netherlands Bureau for Economic Policy Analysis, Den Haag.

Grip, de. A, Boxma, H., Willems, D., Boxtel, M., (2008), Job-Worker Mismatch and Cognitive Decline, Oxford Economic Papers, Vol. 6o, Issue 2, pp. 237-253.

Heijke, H., Meng, C., Ris, C., (2003), Fitting to the job: the role of generic and vocational competenties in adjustment and performance, Labor Economics, Vol. Io(2), pp. 215-229.

Meng, C., (2006), Discipline-specific or Academic? Acquisition, Role and Value of Higher Education Competencies, Maastrciht: ROA.

Ministerie van Onderwijs, Cultuur en Wetenschap (2010) VSV-Atlas: Totaaloverzicht Nederland. Aanval op schooluitval, Convenantjaar 2008-2009, Nieuwe voortijdige schoolverlaters, Definitieve cijfers, Den Haag.

Ministerie van Onderwijs, Cultuur en Wetenschap (20II) Internationale topprestatie Nederland in aanpak voortijdig schoolverlaten, Nieuwsbericht 07-06-20II, Den Haag.

Peschar, J., Wesselingh A., (200I), Onderwijssociologie, Groningen: Wolters-Noordhoff.

Researchcentrum voor Onderwijs en Arbeidsmarkt (2009), Zonder diploma: Aanleiding, Kansen en toekomstintenties, ROA-R-2009/I, Researchcentrum voor Onderwijs en Arbeidsmarkt, Maastricht.

Researchcentrum voor Onderwijs en Arbeidsmarkt (2009b),Schoolverlaters tussen onderwijs en arbeidsmarkt 2008, ROA-R-2009/4, Researchcentrum voor Onderwijs en Arbeidsmarkt, Maastricht.

Researchcentrum voor Onderwijs en Arbeidsmarkt (2010), Voortijdige schoolverlaters: Aanleiding en gevolgen, ROA-R-20Io/9, Researchcentrum voor Onderwijs en Arbeidsmarkt, Maastricht.

Researchcentrum voor Onderwijs en Arbeidsmarkt (20II), MBO-Diploma 20I0: Doorleren of werk zoeken?, ROA-F-20II/I, Researchcentrum voor Onderwijs en Arbeidsmarkt, Maastricht.

Researchcentrum voor Onderwijs en Arbeidsmarkt, (20II), Depreciatie van menselijk kapitaal, ROA-R-20II/I, Researchcentrum voor Onderwijs en Arbeidsmarkt, Maastricht.

Researchcentrum voor Onderwijs en Arbeidsmarkt (2010), MBO-Diploma in tijden van crisis: Doorleren of werk zoeken?, ROA-R-2010/2, Researchcentrum voor Onderwijs en Arbeidsmarkt, Maastricht.

RWI (2009), Onderbenutting bij MBO'ers: Trends en verklaringen, Den Haag: RWI.

Werfhorst, van de HG., (2002), Fields of Study, Acquired Skills and the Wage Benefit from a Matching Job, Acta Sociologica, 45, pp. 287-303. 
HOOFDSTUK 6

Wijk, B., Fleur, E., Smits, E. en Vermeulen, C. (20II) De verloren zonen (m/v). Terugkeer in het onderwijs van voortijdig schoolverlaters, ECBO, Utrecht en 's Hertogenbosch. 
Bijlage 1: Tabel hoofdstuk 1 


\section{Bijlage 1.1}

Regressieanalyse op de natuurlijke logaritme van bruto uurloon

\begin{tabular}{lccc|} 
& MBO-BOL & MBO-BBL & HBO \\
\hline Man & $0.067^{* *}$ & $0.106^{* *}$ & $0.057^{* *}$ \\
Leeftijd & $0.016^{* *}$ & $0.015^{* *}$ & $0.016^{* *}$ \\
\hline Autochtoon & Ref. & Ref. & Ref. \\
\hline Westerse allochtoon & $-0082^{*}$ & 0.034 & $-0.056^{* *}$ \\
\hline Niet-westerse allochtoon & -0.028 & 0.034 & 0.009 \\
\hline MB0 niveau 1 & & & $X$ \\
\hline MBO niveau 2 & $-0.256^{* *}$ & $-0.129^{* *}$ & $X$ \\
\hline MB0 niveau 3 & Ref & Ref. & $X$ \\
\hline MBO niveau 4 & $0.113^{* *}$ & $0.126^{* *}$ & $X$ \\
\hline Verticale match & $0.197^{* *}$ & $0.272^{* *}$ & $0.140^{* *}$ \\
\hline Horizontale match & & & $0.056^{* *}$ \\
\hline Vaste aanstelling & $0.122^{* *}$ & $0.061^{* *}$ & \\
\hline Voltijd werkzaam & $0.043^{* *}$ & 0.016 & $0.049^{* *}$ \\
\hline
\end{tabular}

In de analyses is verder voor de gevolgde onderwijssector gecorrigeerd. */** impact is significant op minimaal $5 \% / 1 \%$ niveau, bron: SIS (ROA), 2010. 
Bijlage 2: Tabellen hoofdstuk 2 


\section{Bijlage 2.1}

Multivariate analyse voor de kans dat gesprek met studie- dan wel gesprek met beroepskeuzeadvies heeft plaatsgevonden (standaard fout tussen haakjes)

\begin{tabular}{|c|c|c|}
\hline & Studiekeuzeadvies & Beroepskeuzeadvies \\
\hline Autochtoon & Referentie & Referentie \\
\hline Westerse Allochtoon & $-0.148(0.160)$ & $0.203(0.182)$ \\
\hline Niet-westerse Allochtoon & $0.075(0.108)$ & $0.001(0.122)$ \\
\hline Leeftijd & $-0.016(0.005)$ & $0.012(0.005)$ \\
\hline Geslacht: man & $-0.337(0.090)$ & $-0.186(0.107)$ \\
\hline Afstudeercijfer & $0.057(0.031)$ & $0.038(0.036)$ \\
\hline Leerweg: MBO-BOL & $0.039(0.093)$ & $-0.116(0.107)$ \\
\hline MB0-niveau & $-0.379(0.041)$ & $-0.170(0.047)$ \\
\hline \multicolumn{3}{|l|}{ Opleidingssector } \\
\hline Gezondheidszorg & Referentie & Referentie \\
\hline Landbouw & $-0.283(0.182)$ & $-0.218(0.215)$ \\
\hline Techniek & $-0.413(0.125)$ & $-0.114(0.147)$ \\
\hline Economie & $-0.236(0.102)$ & $-0.272(0.120)$ \\
\hline Gedrag \& maatschappij & $-0.078(0.112)$ & $-0.242(0.140)$ \\
\hline \multicolumn{3}{|l|}{ Activiteit door scholen } \\
\hline Brochures, website & $0.334(0.082)$ & $0.177(0.095)$ \\
\hline Extra bijeenkomsten & $0.380(0.087)$ & $0.242(0.097)$ \\
\hline Extra aandacht door docenten & $0.393(0.083)$ & $1.094(0.089)$ \\
\hline Studiekeuzeadvies & $x$ & $1.701(0.094)$ \\
\hline Beroepskeuzeadvies & $1.699(0.094)$ & $x$ \\
\hline Meetjaar 2010 & $-0.436(0.078)$ & $-0.429(0.088)$ \\
\hline Constante & $1.082(0.283)$ & $-2.281(0.344)$ \\
\hline
\end{tabular}

Bron: Quickscan 2009; 2010 


\section{Bijlage 2.2}

Analyse op kans dat jongeren alsnog is verder gaan leren (standaard fout tussen haakjes)

\begin{tabular}{lcc} 
& MBO-BOL & MBO-BBL \\
\hline Autochtoon & Referentie & Referentie \\
\hline Westerse Allochtoon & $0.211(0.250)$ & $0.543(0.399)$ \\
\hline Niet-westerse Allochtoon & $0.868(0.137)$ & $0.622(0.341)$ \\
\hline Leeftijd & $-0.063(0.016)$ & $-0.054(0.013)$ \\
\hline Geslacht: man & $0.344(0.141)$ & $-0.462(0.310)$ \\
\hline Afstudeercijfer & $0.095(0.048)$ & $0.272(0.090)$ \\
\hline MBO-niveau & & \\
\hline Opleidingssector & $-0.268(0.061)$ & $-0.650(0.141)$ \\
\hline Gezondheidszorg & & Referentie \\
\hline Landbouw & Referentie & $-0.989(0.553)$ \\
\hline Techniek & $-0.419(0.346)$ & $-0.614(0.418)$ \\
\hline Economie & $0.119(0.201)$ & $-0.168(0.348)$ \\
\hline Gedrag \& maatschappij & $-0.188(0.150)$ & $0.124(0.475)$ \\
\hline Activiteit & $-0.006(0.175)$ & \\
\hline Brochures, website & & $-0.546(0.215)$ \\
\hline Extra bijeenkomsten & & $-0.391(0.941)$ \\
\hline Extra aandacht door docenten & & $-0.041(0.231)$ \\
\hline Studiekeuzeadvies & $0.306(0.125)$ & $0.344(0.235)$ \\
\hline Beroepskeuzeadvies & $0.488(0.124)$ & $0.108(0.247)$ \\
\hline Meetjaar 2010 & $0.274(0.126)$ & $0.361(0.227)$ \\
\hline Constante & $0.992(0.127)$ & $0.963(0.255)$ \\
\hline Bron: Quin & $0.091(0.132)$ & \\
\hline
\end{tabular}

Bron: Quickscan 2009; 2010 


\section{Bijlage 2.3}

Multivariate analyse voor de kans op voortijdig verlaten van vervolgopleiding (standaard fout tussen haakjes)

\begin{tabular}{|c|c|c|}
\hline & MBO-BOL & MBO-BBL \\
\hline \multicolumn{3}{|l|}{ Persoonlijke achtergrondkenmerken } \\
\hline Autochtoon & Referentie & Referentie \\
\hline Westerse Allochtoon & $-1.416(0.730)$ & $x$ \\
\hline Niet-westerse Allochtoon & $0.236(0.256)$ & $-0.767(1.197)$ \\
\hline Leeftijd & $0.014(0.038)$ & $0.007(0.036)$ \\
\hline Geslacht: man & $-0.643(0.208)$ & $-0.589(0.653)$ \\
\hline Familiesituatie ( 15 jaar) thuiswonend bij 2 ouders & $0.003(0.229)$ & $-0.006(0.742)$ \\
\hline \multicolumn{3}{|l|}{ Onderwijsniveau ouders } \\
\hline Vader: laag niveau & $0.201(0.231)$ & $x$ \\
\hline Vader: midden niveau & Referentie & Referentie \\
\hline Vader hoog niveau & $0.109(0.225)$ & $x$ \\
\hline Moeder laag niveau & $-0.447(0.227)$ & $x$ \\
\hline Moeder: midden niveau & Referentie & Referentie \\
\hline Moeder hoog niveau & $-0.492(0.250)$ & $x$ \\
\hline \multicolumn{3}{|l|}{ Afgeronde opleiding } \\
\hline Afstudeercijfer & $-0.141(0.083)$ & $-0.519(0.275)$ \\
\hline MB0 niveau 1 & $0.936(0.435)$ & $-0.547(1.120)$ \\
\hline MBO niveau 2 & Referentie & Referentie \\
\hline MB0 niveau 3 & $-0.262(0.334)$ & $-1.142(0.900)$ \\
\hline MBO niveau 4 & $0.048(0.321)$ & $-0.585(0.805)$ \\
\hline Opleidingssector: Economie & Referentie & Referentie \\
\hline Opleidingssector: Landbouw & $0.182(0.333)$ & $0.298(0.946)$ \\
\hline Opleidingssector: Techniek & $0.308(0.252)$ & $-1.461(0.885)$ \\
\hline Opleidingssector: Gezondheidszorg & $-0.270(0.279)$ & $0.211(0.930)$ \\
\hline Opleidingssector: Gedrag en maatschappij & $0.304(0.254)$ & $-1.587(1.437)$ \\
\hline \multicolumn{3}{|l|}{ Doorstroom binnen opleidingsector } \\
\hline Vervolg in het $\mathrm{BBL}$ & $0.110(0.338)$ & Referentie \\
\hline Vervolg in het BOL & Referentie & $-0.894(0.917)$ \\
\hline Vervolg in het HBO & $0.124(0.286)$ & $-0.635(0.982)$ \\
\hline Voldoende/goede aansluiting & $-1.052(0.179)$ & $-0.197(0.699)$ \\
\hline Individueel gesprek met studiekeuzeadvies & $0.093(0.178)$ & $1.027(0.638)$ \\
\hline Constante & $-1.488(0.897)$ & $0.336(1.624)$ \\
\hline
\end{tabular}

Bron: BVE-Monitor 2010. X: niet opgenomen in analyse in verband met te lage aantal respondenten 
Bijlage 2.4

Multivariate analyse voor de kans op voldoende/goede aansluiting van vervolgopleiding op gevolgde opleiding (standaard fout tussen haakjes)

\begin{tabular}{|c|c|c|}
\hline & MBO-BOL & MBO-BBL \\
\hline \multicolumn{3}{|l|}{ Persoonlijke achtergrondkenmerken } \\
\hline Autochtoon & Referentie & Referentie \\
\hline Westerse Allochtoon & $-0.197(0.265)$ & $0.290(0.884)$ \\
\hline Niet-westerse Allochtoon & $0.140(0.140)$ & $-0.758(0.609)$ \\
\hline Leeftijd & $-0.012(0.026)$ & $0.017(0.026)$ \\
\hline Geslacht: man & $-0.122(0.127)$ & $-0.339(0.459)$ \\
\hline Familiesituatie ( 15 jaar) thuiswonend bij 2 ouders & $0.165(0.150)$ & $0.405(0.471)$ \\
\hline \multicolumn{3}{|l|}{ Onderwijsniveau ouders } \\
\hline Vader: laag niveau & $-0.041(0.153)$ & $0.258(0438)$ \\
\hline Vader: midden niveau & Referentie & Referentie \\
\hline Vader hoog niveau & $0.127(0.144)$ & $0.040(0.460)$ \\
\hline Moeder laag niveau & $0.130(0.148)$ & $-0.017(0.431)$ \\
\hline Moeder: midden niveau & Referentie & Referentie \\
\hline Moeder hoog niveau & $-0.274(0.153)$ & $-0.286(0.541)$ \\
\hline \multicolumn{3}{|l|}{ Afgeronde opleiding } \\
\hline Afstudeercijfer & $0.173(0.055)$ & $0.117(0.159)$ \\
\hline MBO niveau 1 & $1.376(0.543)$ & $-0.357(0.774)$ \\
\hline MBO niveau 2 & Referentie & Referentie \\
\hline MBO niveau 3 & $-0.335(0.208)$ & $-0.332(0.439)$ \\
\hline MB0 niveau 4 & $-0.151(0.211)$ & $-0.575(0.538)$ \\
\hline Opleidingssector: Economie & Referentie & Referentie \\
\hline Opleidingssector: Landbouw & $-0.413(0.213)$ & $-0.667(0.623)$ \\
\hline Opleidingssector: Techniek & $-0.131(0.162)$ & $-0.390(0.469)$ \\
\hline Opleidingssector: Gezondheidszorg & $-0.156(0.173)$ & $-0.094(0.670)$ \\
\hline Opleidingssector: Gedrag en maatschappij & $0.091(0.174)$ & $0.690(0.856)$ \\
\hline Doorstroom binnen opleidingsector & $0.368(0.114)$ & $0.962(0.347)$ \\
\hline Vervolg in het BBL & $-0.028(0.239)$ & Referentie \\
\hline Vervolg in het BOL & Referentie & $0.281(0.595)$ \\
\hline Vervolg in het HBO & $-0.841(0.187)$ & $-1.431(0.471)$ \\
\hline Individueel gesprek met studiekeuzeadvies & $0.543(0.117)$ & $0.995(0.374)$ \\
\hline Constante & $0.793(0.606)$ & $0.834(1.059)$ \\
\hline
\end{tabular}




\section{Bijlage 2.5a}

Kans op werk: Intrede- en enquêtemoment: MBO-BOL (standaard fout tussen haakjes)

\begin{tabular}{|c|c|c|}
\hline & Intrede & Enquête \\
\hline Man & $0.341(0.197)$ & $0.518^{*}(0.273)$ \\
\hline Leeftijd & $-0.039(0.014)$ & $-0.020(0.019)$ \\
\hline Autochtoon & Referentie & Referentie \\
\hline Westerse allochtoon & $-0.489(0.358)$ & $0.209(0.564)$ \\
\hline Niet-westerse allochtoon & $-0.678(0.239)$ & $-0.708(0.300)$ \\
\hline \multicolumn{3}{|l|}{ Woonregio } \\
\hline Noord & $-0.321(0.262)$ & $-0.196(0.372)$ \\
\hline 0ost & $-0.047(0.184)$ & $-0.064(0.256)$ \\
\hline West & Referentie & Referentie \\
\hline Zuid & $0.419(0.350)$ & $-0.060(0.452)$ \\
\hline \multicolumn{3}{|l|}{ Sociale achtergrond } \\
\hline 2 ouders thuis & $-0.272(0.204)$ & $0.488(0.263)$ \\
\hline Opleidingsniveau vader: laag & $0.076(0.205)$ & $-0.113(0.277)$ \\
\hline Opleidingsniveau vader: midden & Referentie & Referentie \\
\hline Opleidingsniveau vader: hoog & $-0.354(0.234)$ & $0.170(0.338)$ \\
\hline Opleidingsniveau moeder: laag & $-0.028(0.202)$ & $-0.083(0.274)$ \\
\hline Opleidingsniveau moeder: midden & Referentie & Referentie \\
\hline Opleidingsniveau moeder: hoog & $-0.088(0.264)$ & $-0.083(0.381)$ \\
\hline Afstudeercijfer & $-0.002(0.076)$ & $0.135(0.102)$ \\
\hline \multicolumn{3}{|l|}{ Opleidingsniveau } \\
\hline Niveau 1 & $0.201(0.448)$ & $-0.836(0.466)$ \\
\hline Niveau 2 & Referentie & Referentie \\
\hline Niveau 3 & $0.665(0.271)$ & $0.718(0.358)$ \\
\hline Niveau 4 & $0.480(0.214)$ & $0.793(0.285)$ \\
\hline \multicolumn{3}{|l|}{ Opleidingssector } \\
\hline Landbouw & $-0.121(0.279)$ & $0.071(0.399)$ \\
\hline Techniek & $-0.208(0.242)$ & $-0.308(0.322)$ \\
\hline Economie & Referentie & Referentie \\
\hline Gezondheidszorg & $0.890(0.258)$ & $0.773(0.355)$ \\
\hline Gedrag \& Maatschappij & $0.373(0.259)$ & $0.255(0.363)$ \\
\hline Gesprek: Arbeidsmarkt & $0.392(0.200)$ & $0.084(0.269)$ \\
\hline Problemen met vinden stage/BPV & $-0.573(0.205)$ & $-0.556(0.270)$ \\
\hline Intredewerkloosheid >=2 maanden & $x$ & $-2.147(0.230)$ \\
\hline Constante & $1.906(0.487)$ & $-2.147(0.657)$ \\
\hline
\end{tabular}

Bron: BVE-Monitor 2010 


\section{Bijlage 2.5b}

Kans op werk: Intrede- en enquêtemoment: MBO-BBL (standaard fout tussen haakjes)

\begin{tabular}{|c|c|c|}
\hline & Intrede & Enquête \\
\hline Man & $-0.075(0.438)$ & $0.582(0.239)$ \\
\hline Leeftijd & $0.004(0.018)$ & $-0.014(0.013)$ \\
\hline Autochtoon & Referentie & Referentie \\
\hline Westerse allochtoon & $0.665(1.051)$ & $0.155(0.492)$ \\
\hline Niet-westerse allochtoon & $-0.607(0.513)$ & $-0.946(0.258)$ \\
\hline \multicolumn{3}{|l|}{ Woonregio } \\
\hline Noord & $-1.651(0.474)$ & $-0.432(0.307)$ \\
\hline 0ost & $-0.410(0.433)$ & $-0.143(0.230)$ \\
\hline West & Referentie & Referentie \\
\hline Zuid & $-0.804(0.646)$ & $-0.314(0.379)$ \\
\hline \multicolumn{3}{|l|}{ Sociale achtergrond } \\
\hline 2 ouders thuis & $0.168(0.446)$ & $0.325(0.238)$ \\
\hline Opleidingsniveau vader: laag & $0.636(0.400)$ & $0.002(0.248)$ \\
\hline Opleidingsniveau vader: midden & Referentie & Referentie \\
\hline Opleidingsniveau vader: hoog & $0.058(0.475)$ & $-0.060(0.288)$ \\
\hline Opleidingsniveau moeder: laag & $-0.751(0.447)$ & $-0.109(0.247)$ \\
\hline Opleidingsniveau moeder: midden & Referentie & Referentie \\
\hline Opleidingsniveau moeder: hoog & $-1.111(0.531)$ & $-0.060(0.334)$ \\
\hline Afstudeercijfer & $0.044(0.151)$ & $0.006(0.090)$ \\
\hline \multicolumn{3}{|l|}{ Opleidingsniveau } \\
\hline Niveau 1 & $0.987(0.795)$ & $0.356(0.759)$ \\
\hline Niveau 2 & Referentie & Referentie \\
\hline Niveau 3 & $1.121(0.427)$ & $0.798(0.418)$ \\
\hline Niveau 4 & $1.136(0.517)$ & $1.716(0.744)$ \\
\hline \multicolumn{3}{|l|}{ Opleidingssector } \\
\hline Landbouw & $0.801(0.625)$ & $0.557(0.372)$ \\
\hline Techniek & $0.672(0.434)$ & $0.095(0.276)$ \\
\hline Economie & Referentie & Referentie \\
\hline Gezondheidszorg & $1.071(0.596)$ & $0.796(0.298)$ \\
\hline Gedrag \& Maatschappij & $0.630(0.843)$ & $0.776(0.330)$ \\
\hline Gesprek: Arbeidsmarkt & $-0.004(0.409)$ & $-0.140(0.229)$ \\
\hline Problemen met vinden stage/BPV & $-1.505(0.452)$ & $-0.676(0.245)$ \\
\hline Intredewerkloosheid $>=2$ maanden & $x$ & $-2.295(0.202)$ \\
\hline Constante & $2.622(0.941)$ & $3.023(0.517)$ \\
\hline
\end{tabular}

Bron: BVE-Monitor 2010 


\section{Bijlage 2.6a}

Kans op werk in eigen domein, op eigen niveau en kans op algemeen goede aansluiting: MBO-BOL (standaard fout tussen haakjes)

\begin{tabular}{|c|c|c|c|}
\hline & Eigen domein & Eigen niveau & Algemeen \\
\hline Man & $-0.027(0.170)$ & $-0.115(0.193)$ & $-0.304(0.171)$ \\
\hline Leeftijd & $-0.011(0.015)$ & $0.033(0.022)$ & $0.049(0.020)$ \\
\hline Autochtoon & Referentie & Referentie & Referentie \\
\hline Westerse allochtoon & $-0.614(0.331)$ & $0.480(0.440)$ & $-0.215(0.348)$ \\
\hline Niet-westerse allochtoon & $-0.596(0.249)$ & $0.517(0.315)$ & $0.208(0.271)$ \\
\hline \multicolumn{4}{|l|}{ Woonregio } \\
\hline Noord & $-0.106(0.248)$ & $-0.041(0.284)$ & $0.274(0.248)$ \\
\hline 0ost & $0.039(0.168)$ & $0.035(0.190)$ & $0.429(0.166)$ \\
\hline West & Referentie & Referentie & Referentie \\
\hline Zuid & $-0.540(0.252)$ & $0.307(0.311)$ & $-0.144(0.246)$ \\
\hline \multicolumn{4}{|l|}{ Sociale achtergrond } \\
\hline 2 ouders thuis & $0.266(0.193)$ & $0.234(0.223)$ & $0.202(0.196)$ \\
\hline Opleidingsniveau vader: laag & $0.154(0.186)$ & $-0.473(0.206)$ & $-0.008(0.185)$ \\
\hline Opleidingsniveau vader: midden & Referentie & Referentie & Referentie \\
\hline Opleidingsniveau vader: hoog & $0.129(0.195)$ & $0.364(0.242)$ & $--0.129(0.189)$ \\
\hline Opleidingsniveau moeder: laag & $-0.146(0.181)$ & $-0.473(0.206)$ & $-0.095(0.177)$ \\
\hline Opleidingsniveau moeder: midden & Referentie & Referentie & Referentie \\
\hline Opleidingsniveau moeder: hoog & $-0.522(0.211)$ & $0.308(0.264)$ & $-0.045(0.213)$ \\
\hline Afstudeercijfer & $0.028(0.071)$ & $0.214(0.084)$ & $0.078(0.071)$ \\
\hline \multicolumn{4}{|l|}{ Opleidingsniveau } \\
\hline Niveau 1 & $0.741(0.496)$ & $-0.326(0.514)$ & $-0.088(0.548)$ \\
\hline Niveau 2 & Referentie & Referentie & Referentie \\
\hline Niveau 3 & $0.635(0.244)$ & $-0.414(0.273)$ & $-0.014(0.262)$ \\
\hline Niveau 4 & $0.455(0.200)$ & $0.052(0.232)$ & $-0.523(0.221)$ \\
\hline \multicolumn{4}{|l|}{ Opleidingssector } \\
\hline Landbouw & $-0.123(0.237)$ & $0.200(0.268)$ & $-0.093(0.255)$ \\
\hline Techniek & $0.347(0.219)$ & $-0.008(0.246)$ & $-0.245(0.226)$ \\
\hline Economie & Referentie & Referentie & Referentie \\
\hline Gezondheidszorg & $1.095(0.228)$ & $0.519(0.258)$ & $-0.437(0.218)$ \\
\hline Gedrag \& Maatschappij & $0.875(0.241)$ & $1.032(0.305)$ & $-0.216(0.234)$ \\
\hline Gesprek: Arbeidsmarkt & $0.310(0.176)$ & $-0.029(0.197)$ & $0.447(0.181)$ \\
\hline Problemen met vinden stage/BPV & $0.013(0.212)$ & $0.024(0.250)$ & $-0.588(0.190)$ \\
\hline Intredewerkloosheid $>=2$ maanden & $-0.319(0.225)$ & $-0.084(0.264)$ & $-0.760(0.214)$ \\
\hline Eigen niveau & $1.959(0.172)$ & $x$ & $0.301(0.193)$ \\
\hline Eigen domein & $x$ & $-1.994(0.175)$ & $0.870(0.170)$ \\
\hline Constante & $-1.115(0.487)$ & $-1.653(0.621)$ & $-0.499(0.544)$ \\
\hline
\end{tabular}

Bron: BVE-Monitor 2010 
Bijlage 2.6b

Kans op werk in eigen domein, op eigen niveau en kans op algemeen goede aansluiting: MBO-BBL (standaard fout tussen haakjes)

\begin{tabular}{|c|c|c|c|}
\hline & Eigen domein & Eigen niveau & Algemeen \\
\hline Man & $0.309(0.228)$ & $0.417(0.224)$ & $-0.469(0.262)$ \\
\hline Leeftijd & $-0.007(0.008)$ & $-0.003(0.008)$ & $-0.012(0.010)$ \\
\hline Autochtoon & Referentie & Referentie & Referentie \\
\hline Westerse allochtoon & $-0.175(0.362)$ & $0.375(0.367)$ & $-0.205(0.401)$ \\
\hline Niet-westerse allochtoon & $0.211(0.316)$ & $0.193(0.319)$ & $0.406(0.399)$ \\
\hline \multicolumn{4}{|l|}{ Woonregio } \\
\hline Noord & $0.216(0.270)$ & $0.046(0.270)$ & $-0.099(0.318)$ \\
\hline Oost & $0.459(0.185)$ & $-0004(0.179)$ & $-0.135(0.216)$ \\
\hline West & Referentie & Referentie & Referentie \\
\hline Zuid & $1.099(0.384)$ & $-0.089(0.321)$ & $-0.474(0.351)$ \\
\hline \multicolumn{4}{|l|}{ Sociale achtergrond } \\
\hline 2 ouders thuis & $0.320(0.220)$ & $0.122(0.216)$ & $0.386(0.245)$ \\
\hline Opleidingsniveau vader: laag & $-0.035(0.211)$ & $-0.464(0.204)$ & $-0.098(0.241)$ \\
\hline Opleidingsniveau vader: midden & Referentie & Referentie & Referentie \\
\hline Opleidingsniveau vader: hoog & $-0.229(0.246)$ & $-0.175(0.239)$ & $-0.052(0.271)$ \\
\hline Opleidingsniveau moeder: laag & $0.101(0.214)$ & $-0.079(0.207)$ & $0.547(0.243)$ \\
\hline Opleidingsniveau moeder: midden & Referentie & Referentie & Referentie \\
\hline Opleidingsniveau moeder: hoog & $0.248(0.299)$ & $-0.339(0.289)$ & $0.237(0.326)$ \\
\hline Afstudeercijfer & $-0.062(0.074)$ & $0.044(0.072)$ & $-0.018(0.085)$ \\
\hline \multicolumn{4}{|l|}{ Opleidingsniveau } \\
\hline Niveau 1 & $0.072(0.333)$ & $-0.843(0.330)$ & $0.351(0.421)$ \\
\hline Niveau 2 & Referentie & Referentie & Referentie \\
\hline Niveau 3 & $0.767(0.196)$ & $-0.690(0.192)$ & $0.513(0.235)$ \\
\hline Niveau 4 & $1.114(0.250)$ & $-0.054(0.239)$ & $0.008(0.261)$ \\
\hline \multicolumn{4}{|l|}{ Opleidingssector } \\
\hline Landbouw & $0.500(0.273)$ & $-0.527(0.269)$ & $0.065(0.319)$ \\
\hline Techniek & $0.767(0.235)$ & $-0.374(0.231)$ & $-0.012(0.258)$ \\
\hline Economie & Referentie & Referentie & Referentie \\
\hline Gezondheidszorg & $1.400(0.287)$ & $0.896(0.275)$ & $0.556(0.354)$ \\
\hline Gedrag \& Maatschappij & $1.142(0.402)$ & $1.984(0.483)$ & $0.237(0.326)$ \\
\hline Gesprek: Arbeidsmarkt & $0.021(1.190)$ & $0.168(0.186)$ & $0.673(0.245)$ \\
\hline Problemen met vinden stage/BPV & $-0.414(0.347)$ & $-0.061(0.340)$ & $-0.835(0.353)$ \\
\hline Intredewerkloosheid >=2 maanden & $-0.542(0.434)$ & $-0.197(0.441)$ & $-1.105(0.432)$ \\
\hline Eigen niveau & $1.451(0.172)$ & $x$ & $0.356(0.211)$ \\
\hline Eigen domein & $x$ & $1.455(0.172)$ & $0.535(0.216)$ \\
\hline Constante & $-1.385(0.490)$ & $-0.017(0.465)$ & $0.929(0.564)$ \\
\hline
\end{tabular}

Bron: BVE-Monitor 2010 


\section{Bijlage 2.7a}

Kans dat capaciteiten goed benut worden en kans op goede carrièremogelijkheden: MBO-BOL (standaard fout tussen haakjes)

\begin{tabular}{|c|c|c|}
\hline & Capaciteiten & Carrière \\
\hline Man & $-0.170(0.155)$ & $0.263(0.144)$ \\
\hline Leeftijd & $-0.002(0.013)$ & $-0.039(0.013)$ \\
\hline Autochtoon & Referentie & Referentie \\
\hline Westerse allochtoon & $-0.254(0.304)$ & $-0.041(0.292)$ \\
\hline Niet-westerse allochtoon & $0.091(0.242)$ & $0.014(0.216)$ \\
\hline \multicolumn{3}{|l|}{ Woonregio } \\
\hline Noord & $-0.038(0.221)$ & $0.033(0.198)$ \\
\hline 0ost & $0.130(0.149)$ & $0.034(0.132)$ \\
\hline West & Referentie & Referentie \\
\hline Zuid & $0.099(0.240)$ & $-0.352(0.214)$ \\
\hline \multicolumn{3}{|l|}{ Sociale achtergrond } \\
\hline 2 ouders thuis & $0.130(0.181)$ & $-0.060(0.165)$ \\
\hline Opleidingsniveau vader: laag & $0.077(0.163)$ & $0.099(0.151)$ \\
\hline Opleidingsniveau vader: midden & Referentie & Referentie \\
\hline Opleidingsniveau vader: hoog & $0.077(0.163)$ & $-0.179(0.154)$ \\
\hline Opleidingsniveau moeder: laag & $0.018(0.194)$ & $-0.160(0.145)$ \\
\hline Opleidingsniveau moeder: midden & Referentie & Referentie \\
\hline Opleidingsniveau moeder: hoog & $0.018(0.194)$ & $-0.250(0.177)$ \\
\hline Afstudeercijfer & $0.099(0.064)$ & $0.043(0.058)$ \\
\hline \multicolumn{3}{|l|}{ Opleidingsniveau } \\
\hline Niveau 1 & $-0.659(0.444)$ & $-1.494(0.456)$ \\
\hline Niveau 2 & Referentie & Referentie \\
\hline Niveau 3 & $-0.204(0.232)$ & $0.028(0.204)$ \\
\hline Niveau 4 & $-0.422(0.196)$ & $-0.070(0.175)$ \\
\hline \multicolumn{3}{|l|}{ Opleidingssector } \\
\hline Landbouw & $0.256(0.228)$ & $-0.554(0.214)$ \\
\hline Techniek & $0.061(0.202)$ & $-0.395(0.192)$ \\
\hline Economie & Referentie & Referentie \\
\hline Gezondheidszorg & $0.707(0.202)$ & $-0.028(0.176)$ \\
\hline Gedrag \& Maatschappij & $0.414(0.206)$ & $-0.477(0.186)$ \\
\hline Gesprek: Arbeidsmarkt & $0.312(0.158)$ & $0.391(0.139)$ \\
\hline Problemen met vinden stage/BPV & $-0.236(0.188)$ & $-0.115(0.171)$ \\
\hline Intredewerkloosheid $>=2$ maanden & $-0.531(0.207)$ & $-0.618(0.200)$ \\
\hline Eigen niveau & $0.300(0.177)$ & $0.583(0.171)$ \\
\hline Eigen domein & $1.332(0.154)$ & $0.264(0.149)$ \\
\hline Constante & $-1.115(0.445)$ & $0.543(0.412)$ \\
\hline
\end{tabular}

Bron: BVE-Monitor 2010 


\section{Bijlage 2.7b}

Kans dat capaciteiten goed benut worden en kans op functie met goede carrièremogelijkheden: MBO-BBL (standaard fout tussen haakjes)

\begin{tabular}{|c|c|c|}
\hline & Capaciteiten & Carrière \\
\hline Man & $-0.449(0.211)$ & $0.124(0.200)$ \\
\hline Leeftijd & $-0.012(0.008)$ & $-0.040(0.007)$ \\
\hline Autochtoon & Referentie & Referentie \\
\hline Westerse allochtoon & $0.060(0.335)$ & $-0.093(0.298)$ \\
\hline Niet-westerse allochtoon & $0.199(0.308)$ & $1.058(0.284)$ \\
\hline \multicolumn{3}{|l|}{ Woonregio } \\
\hline Noord & $-0.464(0.247)$ & $-0.056(0.233)$ \\
\hline 0ost & $-0.294(0.172)$ & $-0.179(0.156)$ \\
\hline West & Referentie & Referentie \\
\hline Zuid & $-0.542(0.293)$ & $-0.060(0.273)$ \\
\hline \multicolumn{3}{|l|}{ Sociale achtergrond } \\
\hline 2 ouders thuis & $0.204(0.204)$ & $0.297(0.193)$ \\
\hline Opleidingsniveau vader: laag & $-0.204(0.189)$ & $-0.092(0.173)$ \\
\hline Opleidingsniveau vader: midden & Referentie & Referentie \\
\hline Opleidingsniveau vader: hoog & $0.039(0.228)$ & $-0.125(0.204)$ \\
\hline Opleidingsniveau moeder: laag & $-0.035(0.193)$ & $-0.208(0.176)$ \\
\hline Opleidingsniveau moeder: midden & Referentie & Referentie \\
\hline Opleidingsniveau moeder: hoog & $-0.068(0.275)$ & $-0.414(0.249)$ \\
\hline Afstudeercijfer & $0.112(0.068)$ & $0.167(0.063)$ \\
\hline \multicolumn{3}{|l|}{ Opleidingsniveau } \\
\hline Niveau 1 & $0.735(0.345)$ & $-0.006(0.329)$ \\
\hline Niveau 2 & Referentie & Referentie \\
\hline Niveau 3 & $0.281(0.183)$ & $-0.039(0.172)$ \\
\hline Niveau 4 & $0.131(0.214)$ & $0.359(0.199)$ \\
\hline \multicolumn{3}{|l|}{ Opleidingssector } \\
\hline Landbouw & $-0.209(0.258)$ & $-0.635(0.257)$ \\
\hline Techniek & $0.131(0.216)$ & $-0.211(0.210)$ \\
\hline Economie & Referentie & Referentie \\
\hline Gezondheidszorg & $0.556(0.268)$ & $0.114(0.240)$ \\
\hline Gedrag \& Maatschappij & $0.466(0.346)$ & $-0.314(0.296)$ \\
\hline Gesprek: Arbeidsmarkt & $0.238(0.178)$ & $0.467(0.490)$ \\
\hline Problemen met vinden stage/BPV & $-0.549(0.315)$ & $-0.107(0.311)$ \\
\hline Intredewerkloosheid $>=2$ maanden & $-0.697(0.415)$ & $-1.388(0.490)$ \\
\hline Eigen niveau & $0.343(0.171)$ & $0.152(0.164)$ \\
\hline Eigen domein & $0.581(0.175)$ & $0.269(0.171)$ \\
\hline Constante & $0.199(0.452)$ & $0.148(0.418)$ \\
\hline
\end{tabular}

Bron: BVE-Monitor 2010 

Bijlage 3: Tabellen hoofdstuk 3 


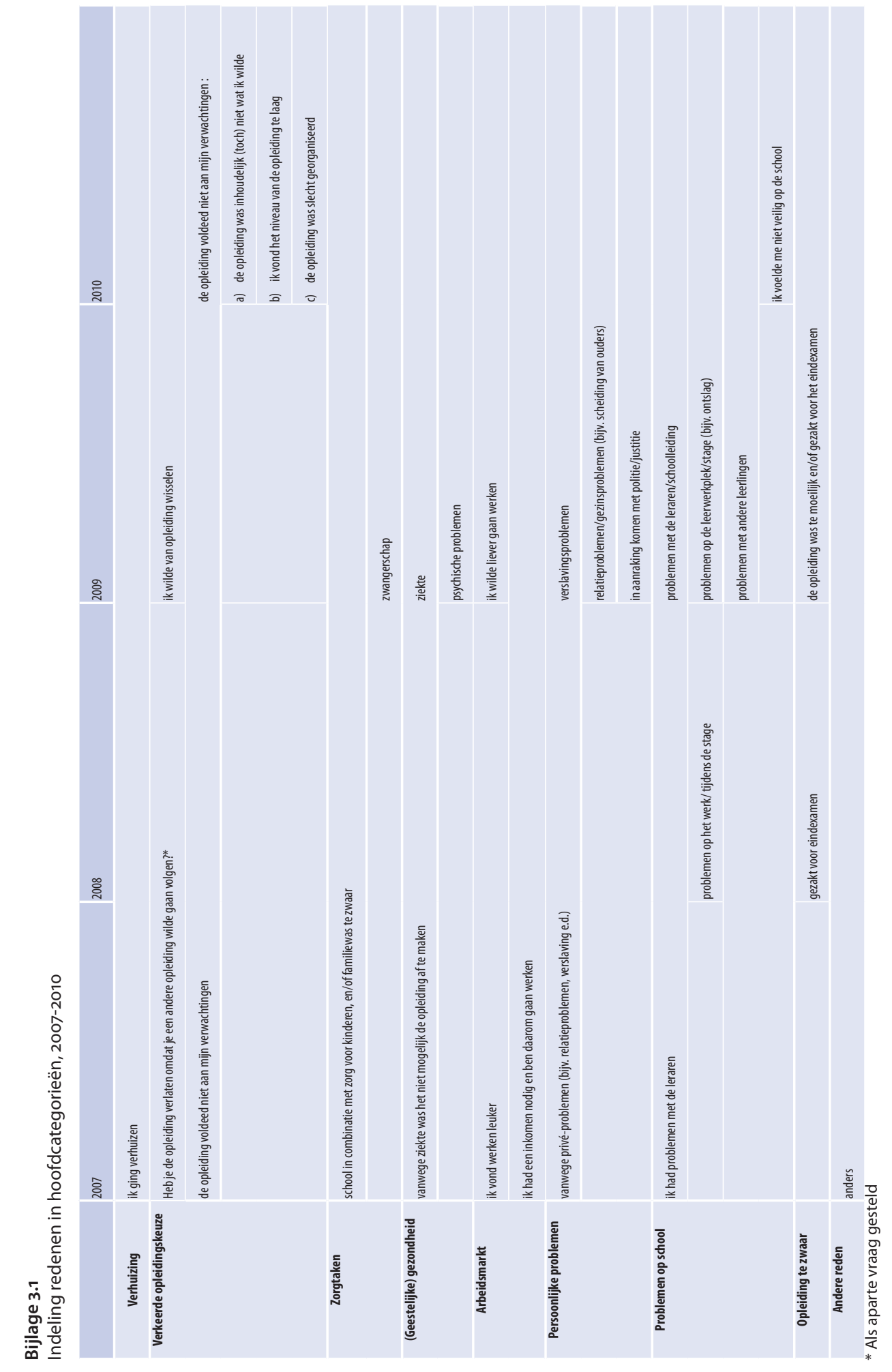

$\overline{104}$ 


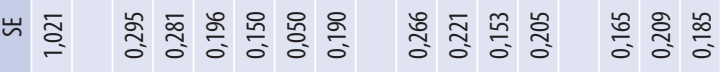

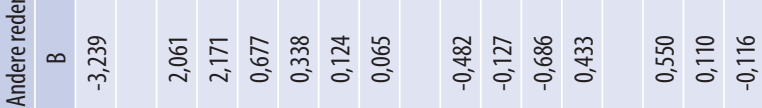

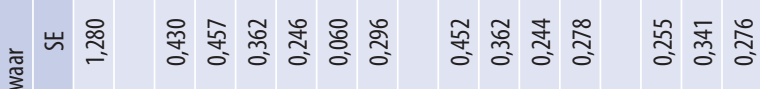

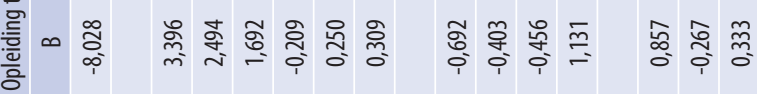

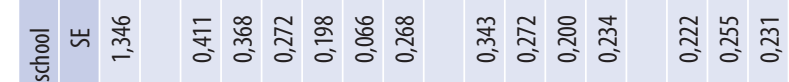

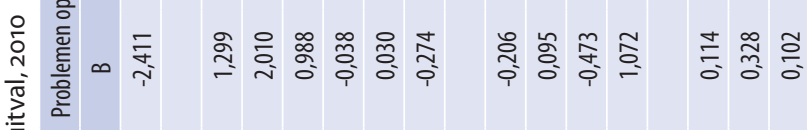

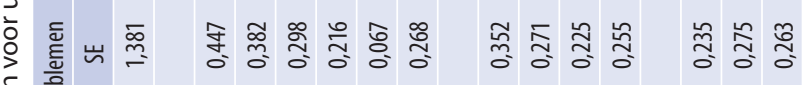

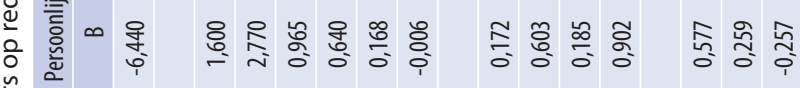

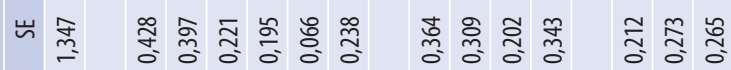

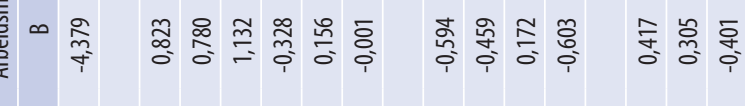

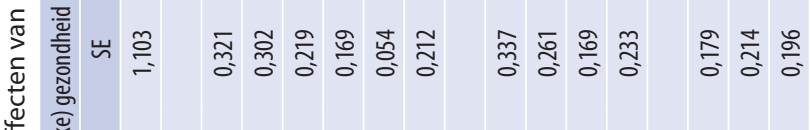

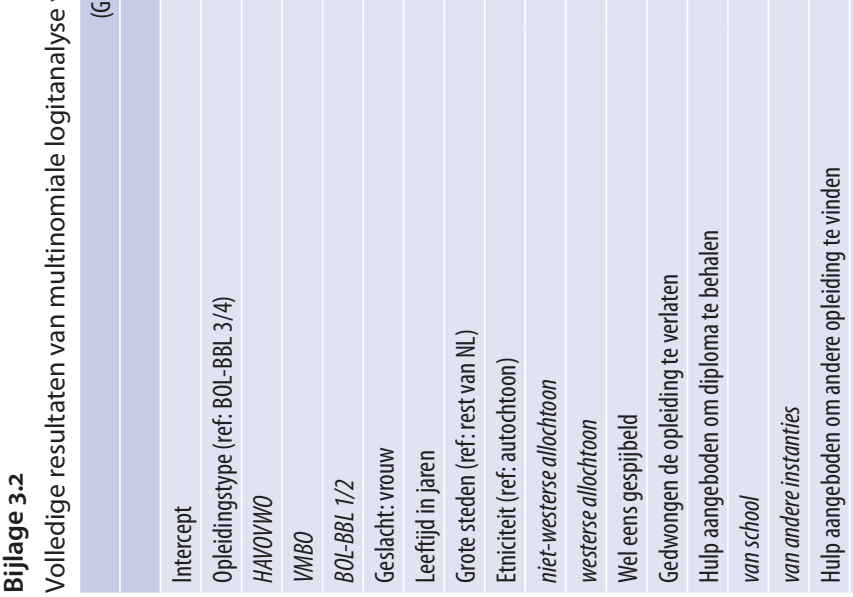




\section{Bijlage 3.3}

Volledige resultaten van een logistische regressieanalyse van de kans op een succesvolle terugkeer

\begin{tabular}{|c|c|c|}
\hline & B & S.E. \\
\hline \multicolumn{3}{|l|}{ Opleidingstype initiële opleiding (ref. BOL-BBL 3/4) } \\
\hline HAVOVWO & 1,085 & 0,281 \\
\hline VMBO & 0,341 & 0,277 \\
\hline$B O L-B B L 1 / 2$ & $-0,624$ & 0,224 \\
\hline Geslacht: vrouw (ref.: mannen) & 0,112 & 0,158 \\
\hline Leeftijd in jaren & $-0,191$ & 0,057 \\
\hline Grote steden (ref. rest van NL) & $-0,157$ & 0,199 \\
\hline \multicolumn{3}{|l|}{ Etniciteit (ref: autochtoon) } \\
\hline niet westerse allochtoon & 0,087 & 0,295 \\
\hline westerse allochtoon & 0,189 & 0,219 \\
\hline \multicolumn{3}{|c|}{ Belangrijkste reden om te stoppen (ref.: Verkeerde opleidingskeuze) } \\
\hline Verhuizing & $-0,324$ & 0,628 \\
\hline Zorgtaken & $-1,045$ & 0,535 \\
\hline (Geestelijke) gezondheid & $-0,717$ & 0,256 \\
\hline Arbeidsmarkt & $-1,172$ & 0,309 \\
\hline Persoonlijke problemen & $-0,757$ & 0,344 \\
\hline Problemen op school & $-0,818$ & 0,304 \\
\hline Opleiding te zwaar & $-0,211$ & 0,385 \\
\hline Andere reden & 0,000 & 0,274 \\
\hline Geen reden genoemd & $-0,465$ & 0,291 \\
\hline Wel eens gespijbeld & $-0,286$ & 0,159 \\
\hline Gedwongen de opleiding te verlaten & 0,367 & 0,204 \\
\hline \multicolumn{3}{|l|}{ Hulp aangeboden om diploma te behalen } \\
\hline van school & 0,001 & 0,166 \\
\hline van andere instanties & $-0,309$ & 0,203 \\
\hline Hulp aangeboden om andere opleiding te vinden & 0,325 & 0,176 \\
\hline Constante & 3,711 & 1,141 \\
\hline
\end{tabular}

Bron: VSV-Monitor 2010 
Bijlage 4: Kernindicatoren 
Kernindicatoren 2010

\begin{tabular}{|c|c|c|c|c|c|c|c|c|c|}
\hline \multirow[t]{2}{*}{ Opleidingssector } & \multirow[t]{2}{*}{$\begin{array}{l}\text { benaderde } \\
\text { aantallen }\end{array}$} & \multirow[t]{2}{*}{$\begin{array}{r}\text { verder } \\
\text { leren }\end{array}$} & $\begin{array}{r}\text { zelfde } \\
\text { opleiding } \\
\text { opnieuw } \\
\text { kiezen }{ }^{11}\end{array}$ & $\begin{array}{r}\text { werk- } \\
\text { loosheid }\end{array}$ & \multirow[t]{2}{*}{$\begin{array}{r}\text { intrede } \\
\text { werk- } \\
\text { loosheid }\end{array}$} & $\begin{array}{r}\text { flexibele } \\
\text { aanstelling }\end{array}$ & $\begin{array}{r}\text { bruto } \\
\text { uurloon }\end{array}$ & $\begin{array}{r}\text { minimaal } \\
\text { eigen } \\
\text { niveau }\end{array}$ & \multirow[t]{2}{*}{$\begin{array}{r}\text { eigen/ } \\
\text { verwante } \\
\text { richting } \\
\%\end{array}$} \\
\hline & & & $\%$ & $\%$ & & $\%$ & $€$ & $\%$ & \\
\hline HAVO/VWO & 3.603 & 87 & 95 & 15 & $\mathbf{x}$ & 52 & 6,05 & $\mathbf{x}$ & \\
\hline HAVO & 1.922 & 86 & 94 & 14 & $x$ & 50 & 5,68 & $x$ & \\
\hline vwo & 1.681 & 88 & 97 & 18 & $x$ & 57 & 7,68 & $x$ & \\
\hline VMBO & 10.519 & 96 & 84 & 8 & 0,4 & 60 & 4,68 & 92 & 65 \\
\hline \multicolumn{10}{|l|}{ Naar leerweg } \\
\hline Theoretisch & 3.189 & 97 & 89 & 17 & 0,5 & 66 & 4,63 & 87 & 53 \\
\hline Gemengd & 779 & 98 & 88 & 21 & 0,1 & 64 & 4,73 & 93 & 59 \\
\hline Kaderberoepsgericht & 3.224 & 98 & 81 & 5 & 0,4 & 62 & 4,75 & 91 & 62 \\
\hline Basisberoepsgericht & 3.327 & 95 & 80 & 5 & 0,5 & 57 & 4,61 & 94 & 70 \\
\hline
\end{tabular}

\begin{tabular}{|c|c|c|c|c|c|c|c|c|c|}
\hline \multicolumn{10}{|l|}{ Naar sector } \\
\hline Landbouw & 3.292 & 96 & 83 & 8 & 0,4 & 63 & 4,50 & 92 & 72 \\
\hline Techniek & 1.245 & 95 & 82 & 3 & 0,2 & 50 & 5,15 & 95 & 75 \\
\hline Economie & 1.399 & 98 & 76 & 11 & 0,4 & 72 & 3,91 & 89 & 62 \\
\hline Gezondheidszorg & 1.394 & 96 & 82 & 5 & 1,1 & 66 & 4,32 & 90 & 50 \\
\hline MBO & 29.083 & 45 & 80 & 6 & 0,4 & 36 & 10,69 & 75 & 72 \\
\hline BOL & 19.611 & 56 & 78 & 8 & 0,7 & 51 & 9,72 & 81 & 73 \\
\hline BoL niveau 1 & 992 & 67 & 72 & 25 & 0,8 & 63 & 5,96 & 79 & 77 \\
\hline BOL niveau 2 & 4.290 & 58 & 75 & 14 & 0,9 & 53 & 8,02 & 74 & 59 \\
\hline Landbouw & 324 & 52 & 72 & 12 & 1,1 & 49 & 9,02 & 82 & 50 \\
\hline Techniek & 850 & 60 & 64 & 17 & 0,7 & 53 & 8,63 & 86 & 59 \\
\hline Economie & 1.840 & 52 & 76 & 13 & 0,8 & 51 & 7,54 & 62 & 47 \\
\hline Gezondheidszorg & 1.276 & 65 & 81 & 14 & 1,3 & 57 & 8,19 & 81 & 79 \\
\hline BoL niveau 3 & 4.013 & 48 & 79 & 5 & 0,5 & 49 & 9,77 & 77 & 78 \\
\hline Landbouw & 354 & 45 & 73 & 4 & 0,3 & 44 & 7,57 & 73 & 56 \\
\hline Techniek & 260 & 43 & 92 & 7 & 0,4 & 47 & 10,57 & 53 & 70 \\
\hline Economie & 1.346 & 64 & 73 & 10 & 0,7 & 66 & 8,44 & 68 & 65 \\
\hline Gezondheidszorg & 898 & 40 & 78 & 1 & 0,5 & 46 & 10,09 & 76 & 81 \\
\hline Gedrag en maatschappij & 1.115 & 42 & 85 & 5 & 0,4 & 44 & 10,59 & 94 & 90 \\
\hline BoL niveau 4 & 10.316 & 57 & 79 & 6 & 0,6 & 50 & 10,64 & 87 & 76 \\
\hline Landbouw & 574 & 53 & 75 & 9 & 0,4 & 52 & 9,45 & 76 & 67 \\
\hline Techniek & 2.267 & 56 & 79 & 8 & 0,6 & 53 & 10,94 & 82 & 70 \\
\hline Economie & 3.808 & 65 & 76 & 8 & 0,9 & 53 & 9,25 & 81 & 65 \\
\hline Gezondheidszorg & 1.420 & 45 & 81 & 1 & 0,4 & 47 & 11,63 & 95 & 87 \\
\hline Gedrag en maatschappij & 2.247 & 56 & 81 & 6 & 0,6 & 48 & 11,16 & 92 & 83 \\
\hline
\end{tabular}


Kernindicatoren 2010

\begin{tabular}{|c|c|c|c|c|c|c|c|c|c|}
\hline Opleidingssector & $\begin{array}{r}\text { benaderde } \\
\text { aantallen }\end{array}$ & $\begin{array}{c}\text { verder } \\
\text { leren }\end{array}$ & $\begin{array}{r}\text { zelfde } \\
\text { opleiding } \\
\text { opnieuw } \\
\text { kiezen }{ }^{1)}\end{array}$ & $\begin{array}{l}\text { werk- } \\
\text { loosheid }\end{array}$ & $\begin{array}{r}\text { intrede } \\
\text { werk- } \\
\text { loosheid }\end{array}$ & $\begin{array}{r}\text { flexibele } \\
\text { aanstelling }\end{array}$ & $\begin{array}{r}\text { bruto } \\
\text { uurloon }\end{array}$ & $\begin{array}{r}\text { minimaal } \\
\text { eigen } \\
\text { niveau }\end{array}$ & $\begin{array}{r}\text { eigen/ } \\
\text { verwante } \\
\text { richting }\end{array}$ \\
\hline & & $\%$ & $\%$ & $\%$ & maanden & $\%$ & $€$ & $\%$ & $\%$ \\
\hline BBL & 9.472 & 29 & 83 & 3 & 0,3 & 25 & 11,40 & 69 & 72 \\
\hline BBL niveau 1 & 938 & 29 & 75 & 7 & 0,0 & 20 & 9,10 & 44 & 51 \\
\hline BBL niveau 2 & 3.685 & 34 & 81 & 5 & 0,4 & 35 & 10,30 & 69 & 64 \\
\hline Landbouw & 446 & 23 & 82 & 0 & 0,5 & 30 & 9,47 & 59 & 53 \\
\hline Techniek & 1.911 & 45 & 81 & 4 & 0,4 & 41 & 9,97 & 69 & 66 \\
\hline Economie & 867 & 22 & 78 & 7 & 0,4 & 35 & 9,96 & 67 & 54 \\
\hline Gezondheidszorg & 461 & 18 & 84 & 6 & 0,3 & 18 & 12,35 & 74 & 79 \\
\hline BBL niveau 3 & 3.130 & 25 & 85 & 2 & 0,3 & 21 & 11,95 & 68 & 79 \\
\hline Landbouw & 258 & 21 & 90 & 1 & 0,0 & 22 & 10,79 & 61 & 84 \\
\hline Techniek & 1.095 & 34 & 84 & 0 & 0,2 & 18 & 13,03 & 55 & 79 \\
\hline Economie & 774 & 31 & 78 & 6 & 0,1 & 29 & 9,34 & 59 & 62 \\
\hline Gezondheidszorg & 762 & 11 & 95 & 1 & 0,0 & 19 & 12,65 & 84 & 88 \\
\hline Gedrag en maatschappij & 241 & 18 & 77 & 0 & 2,0 & 21 & 11,43 & 93 & 87 \\
\hline BBL niveau 4 & 1.719 & 24 & 83 & 2 & 0,1 & 15 & 13,70 & 84 & 83 \\
\hline Landbouw & 104 & 7 & 93 & 0 & - & - & - & - & - \\
\hline Techniek & 333 & 34 & 87 & 0 & 0,0 & 12 & 14,48 & 74 & 81 \\
\hline Economie & 542 & 39 & 69 & 6 & 0,2 & 24 & 10,66 & 73 & 65 \\
\hline Gezondheidszorg & 405 & 14 & 78 & 1 & 0,2 & 15 & 14,54 & 93 & 90 \\
\hline Gedrag en maatschappij & 335 & 18 & 94 & 2 & 0,0 & 12 & 14,21 & 91 & 88 \\
\hline HBO & 40.882 & 36 & 79 & 6 & 1,2 & 51 & 13,53 & 79 & 79 \\
\hline Landbouw & 1.146 & 33 & 78 & 6 & 1,2 & 53 & 13,72 & 76 & 72 \\
\hline Onderwijs & 4.266 & 35 & 87 & 5 & 0,7 & 52 & 13,89 & 94 & 95 \\
\hline Techniek & 6.768 & 36 & 84 & 5 & 1,2 & 46 & 14,15 & 85 & 86 \\
\hline Economie & 17.118 & 43 & 72 & 8 & 1,7 & 53 & 13,33 & 77 & 66 \\
\hline Gezondheidszorg & 4.001 & 32 & 85 & 3 & 0,7 & 42 & 15,06 & 82 & 93 \\
\hline Gedrag en maatschappij & 4.363 & 29 & 75 & 7 & 1,3 & 55 & 13,62 & 62 & 87 \\
\hline Taal en cultuur & 3.220 & 23 & 87 & 6 & 1,1 & 59 & 9,52 & 77 & 68 \\
\hline Totaal & 84.087 & 66 & 81 & 6 & 0,7 & 43 & 10,29 & 77 & 73 \\
\hline
\end{tabular}

- = te weinig waarnemingen; $\mathrm{x}=\mathrm{vraag}$ niet opgenomen 
Kernindicatoren 1999-2010

\begin{tabular}{|c|c|c|c|c|c|c|c|c|c|c|c|c|c|}
\hline & & 1999 & 2000 & 2001 & 2002 & 2003 & 2004 & 2005 & 2006 & 2007 & 2008 & 2009 & 2010 \\
\hline \multicolumn{14}{|c|}{ Verder leren } \\
\hline AVO & $\%$ & 95 & 96 & 95 & 86 & 90 & 91 & 87 & 88 & 88 & 90 & 89 & 87 \\
\hline VMBO & $\%$ & 92 & 94 & 91 & 86 & 87 & 88 & 85 & 87 & 89 & 92 & 95 & 96 \\
\hline BOL 1 & $\%$ & 44 & 51 & 51 & 36 & 53 & 38 & 34 & 45 & 23 & 53 & 51 & 67 \\
\hline BOL 2 & $\%$ & 51 & 46 & 52 & 45 & 52 & 49 & 36 & 63 & 32 & 60 & 59 & 58 \\
\hline BOL 3 & $\%$ & 39 & 42 & 32 & 30 & 33 & 33 & 26 & 40 & 27 & 43 & 43 & 48 \\
\hline BOL 4 & $\%$ & 49 & 50 & 49 & 51 & 52 & 56 & 55 & 56 & 55 & 57 & 55 & 57 \\
\hline BBL 1 & $\%$ & - & - & - & - & - & - & - & - & 10 & 30 & 25 & 29 \\
\hline BBL 2 & $\%$ & - & - & - & - & - & - & - & - & 19 & 35 & 33 & 34 \\
\hline BBL 3 & $\%$ & - & - & - & - & - & - & - & - & 13 & 24 & 21 & 25 \\
\hline BBL 4 & $\%$ & - & - & - & - & - & - & - & - & 15 & 17 & 18 & 24 \\
\hline HBO & $\%$ & 23 & 27 & 26 & 27 & 33 & 32 & 32 & 32 & 35 & 36 & 36 & 36 \\
\hline wo & $\%$ & 29 & 26 & 27 & 27 & 29 & 31 & 30 & 30 & 32 & 35 & 31 & $x$ \\
\hline
\end{tabular}

$\%$ schoolverlaters dat direct is doorgestroomd naar een vervolgopleiding.

\begin{tabular}{|c|c|c|c|c|c|c|c|c|c|c|c|c|c|}
\hline \multicolumn{14}{|c|}{ Werkloosheid } \\
\hline AVO & $\%$ & 1 & * & 0 & 7 & 16 & 17 & 19 & 10 & 19 & 15 & 16 & 15 \\
\hline VMBO & $\%$ & 5 & 4 & 8 & 4 & 9 & 6 & 12 & 6 & 6 & 9 & 6 & 8 \\
\hline BOL 1 & $\%$ & 4 & 8 & 11 & 23 & 20 & 31 & 30 & 22 & 10 & 16 & 30 & 25 \\
\hline BOL 2 & $\%$ & 2 & 5 & 7 & 5 & 15 & 23 & 17 & 11 & 8 & 8 & 12 & 14 \\
\hline BOL 3 & $\%$ & 2 & 3 & 1 & 4 & 5 & 13 & 9 & 7 & 4 & 5 & 11 & 5 \\
\hline BOL 4 & $\%$ & 2 & 3 & 2 & 4 & 4 & 10 & 7 & 6 & 3 & 3 & 6 & 6 \\
\hline BBL 1 & $\%$ & - & - & - & - & - & - & - & - & 5 & 1 & 9 & 7 \\
\hline BBL 2 & $\%$ & - & - & - & - & - & - & - & - & 3 & 1 & 3 & 5 \\
\hline BBL 3 & $\%$ & - & - & - & - & - & - & - & - & 0 & 1 & 3 & 2 \\
\hline BBL 4 & $\%$ & - & - & - & - & - & - & - & - & 2 & 1 & 1 & 2 \\
\hline HBO & $\%$ & 3 & 4 & 3 & 4 & 6 & 6 & 5 & 5 & 3 & 4 & 6 & 6 \\
\hline wo & $\%$ & 3 & 3 & 3 & 3 & 5 & 5 & 4 & 4 & 3 & 4 & 5 & $X$ \\
\hline
\end{tabular}

\section{Flexibele aanstelling}

$\begin{array}{llrrrrrrrrrrrr}\text { AV0 } & \% & 28 & * & 25 & 47 & 40 & 37 & 53 & 63 & 65 & 59 & 42 & 52 \\ \text { VMB0 } & \% & 18 & 11 & 19 & 27 & 32 & 44 & 54 & 48 & 56 & 63 & 63 & 60 \\ \text { BOL 1 } & \% & 21 & 17 & 23 & 46 & 25 & 48 & 47 & 74 & 72 & 56 & 61 & 63 \\ \text { BOL2 } & \% & 22 & 22 & 21 & 26 & 35 & 47 & 46 & 51 & 46 & 54 & 54 & 53 \\ \text { BOL3 } & \% & 20 & 16 & 12 & 20 & 28 & 38 & 43 & 49 & 44 & 43 & 43 & 49 \\ \text { BOL 4 } & \% & 18 & 16 & 14 & 22 & 31 & 40 & 43 & 42 & 40 & 36 & 44 & 50 \\ \text { BBL 1 } & \% & - & - & - & - & - & - & - & - & 16 & 29 & 20 & 20 \\ \text { BBL 2 } & \% & - & - & - & - & - & - & - & - & 27 & 30 & 30 & 35 \\ \text { BBL 3 } & \% & - & - & - & - & - & - & - & - & 18 & 19 & 25 & 21 \\ \text { BBL 4 } & \% & - & - & - & - & - & - & - & - & 14 & 13 & 13 & 15 \\ \text { HB0 } & \% & 13 & 12 & 12 & 13 & 37 & 41 & 44 & 44 & 39 & 38 & 46 & 51 \\ \text { W0 } & \% & 10 & 9 & 9 & 11 & 50 & 52 & 52 & 51 & 46 & 50 & - & \text { X }\end{array}$

Een flexibele aanstelling betreft een aanstelling als uitzendkracht, oproepkracht e.d. of een aanstelling in tijdelijke dienst. 
Kernindicatoren 1999-2010

\begin{tabular}{lrrrrrrrrrrrrr}
\multicolumn{2}{l}{ Bruto uurloon } & 1999 & 2000 & 2001 & 2002 & 2003 & 2004 & 2005 & 2006 & 2007 & 2008 & 2009 & 2010 \\
AV0 & $€$ & 6.07 & $*$ & 6.86 & 6.48 & 6.15 & 6.33 & 6.02 & 6.09 & 6.40 & 6.88 & 6.96 & 6.05 \\
VMB0 & $€$ & 4.37 & 4.20 & 4.44 & 4.66 & 4.68 & 4.54 & 4.76 & 4.91 & 4.85 & 4.85 & 4.83 & 4.68 \\
BOL 1 & $€$ & 5.54 & 5.86 & 6.51 & 7.06 & 5.64 & 6.41 & 6.69 & 5.55 & 7.85 & 6.48 & 6.57 & 5.96 \\
BOL 2 & $€$ & 6.10 & 6.15 & 7.20 & 6.74 & 6.54 & 6.88 & 6.94 & 6.86 & 7.60 & 7.69 & 7.85 & 8.02 \\
BOL 3 & $€$ & 6.87 & 7.39 & 7.81 & 7.87 & 8.24 & 7.97 & 7.99 & 8.64 & 9.45 & 9.33 & 10.04 & 9.77 \\
BOL 4 & $€$ & 7.90 & 8.15 & 8.91 & 8.44 & 8.52 & 8.68 & 8.75 & 9.45 & 10.10 & 10.19 & 10.36 & 10.64 \\
BBL 1 & $€$ & - & - & - & - & - & - & - & - & 9.00 & 9.25 & 9.28 & 9.10 \\
BBL2 & $€$ & - & - & - & - & - & - & - & - & 9.80 & 9.90 & 10.12 & 10.30 \\
BBL3 & $€$ & - & - & - & - & - & - & - & - & 11.40 & 11.68 & 11.72 & 11.95 \\
BBL 4 & $€$ & - & - & - & - & - & - & - & - & 12.65 & 12.81 & 13.13 & 13.70 \\
HBO & $€$ & 10.89 & 11.37 & 11.59 & 11.90 & 12.05 & 11.70 & 11.74 & 12.68 & 13.10 & 13.79 & 13.36 & 13.53 \\
W0 & $€$ & 12.00 & 13.24 & 13.29 & 13.83 & 14.06 & 14.14 & 14.39 & 14.76 & 15.60 & 15.84 & 15.76 & $X$
\end{tabular}

Het bruto uurloon heeft betrekking op de hoofdfunctie, en is inclusief toeslagen maar exclusief inkomen uit overwerk.

\begin{tabular}{|c|c|c|c|c|c|c|c|c|c|c|c|c|c|}
\hline \multicolumn{14}{|c|}{ Minimaal eigen niveau } \\
\hline AVO & $\%$ & - & - & - & - & - & - & - & - & - & - & - & - \\
\hline VMBO & $\%$ & 74 & 71 & 79 & 84 & 87 & 87 & 87 & 87 & 60 & 88 & 86 & 92 \\
\hline BOL 1 & $\%$ & 23 & 25 & 30 & 32 & 52 & 44 & 29 & 68 & 60 & 59 & 57 & 79 \\
\hline BOL 2 & $\%$ & 61 & 56 & 49 & 64 & 68 & 63 & 61 & 63 & 64 & 73 & 68 & 74 \\
\hline BOL 3 & $\%$ & 62 & 73 & 64 & 65 & 75 & 65 & 64 & 77 & 79 & 84 & 76 & 77 \\
\hline BOL 4 & $\%$ & 76 & 80 & 73 & 71 & 70 & 76 & 79 & 83 & 84 & 86 & 85 & 87 \\
\hline BBL 1 & $\%$ & - & - & - & - & - & - & - & - & 46 & 51 & 51 & 44 \\
\hline BBL 2 & $\%$ & - & - & - & - & - & - & - & - & 64 & 71 & 62 & 69 \\
\hline BBL 3 & $\%$ & - & - & - & - & - & - & - & - & 68 & 65 & 61 & 68 \\
\hline BBL 4 & $\%$ & - & - & - & - & - & - & - & - & 87 & 82 & 82 & 84 \\
\hline HBO & $\%$ & 81 & 80 & 79 & 77 & 76 & 75 & 77 & 82 & 85 & 84 & 82 & 80 \\
\hline wo & $\%$ & 63 & 66 & 66 & 66 & 64 & 63 & 61 & 65 & 64 & 67 & 67 & $x$ \\
\hline
\end{tabular}

Het minimaal eigen niveau betreft het opleidingsniveau dat door de werkgever voor deze functie minimaal vereist is.

\begin{tabular}{|c|c|c|c|c|c|c|c|c|c|c|c|c|c|}
\hline \multicolumn{14}{|c|}{ Eigen/verwante richting } \\
\hline AVO & $\%$ & - & - & - & - & - & - & - & - & - & - & - & - \\
\hline VMBO & $\%$ & - & - & 53 & 62 & 62 & 64 & 58 & 62 & 48 & 57 & 51 & 65 \\
\hline BOL 1 & $\%$ & - & - & 37 & 46 & 38 & 56 & 49 & 51 & 37 & 53 & 54 & 77 \\
\hline BOL 2 & $\%$ & - & - & 57 & 62 & 58 & 64 & 53 & 57 & 50 & 56 & 58 & 59 \\
\hline BOL 3 & $\%$ & - & - & 76 & 71 & 78 & 70 & 67 & 74 & 73 & 76 & 76 & 78 \\
\hline BOL 4 & $\%$ & - & - & 70 & 73 & 70 & 69 & 72 & 77 & 76 & 74 & 76 & 76 \\
\hline BBL 1 & $\%$ & - & - & - & - & - & - & - & - & 52 & 52 & 41 & 51 \\
\hline BBL 2 & $\%$ & - & - & - & - & - & - & - & - & 65 & 62 & 61 & 64 \\
\hline BBL 3 & $\%$ & - & - & - & - & - & - & - & - & 79 & 77 & 78 & 79 \\
\hline BBL 4 & $\%$ & - & - & - & - & - & - & - & - & 84 & 81 & 83 & 83 \\
\hline HBO & $\%$ & - & - & 76 & 78 & 79 & 78 & 76 & 80 & 82 & 82 & 80 & 79 \\
\hline wo & $\%$ & 71 & 71 & 71 & 73 & 71 & 72 & 70 & 74 & 74 & 71 & 73 & $X$ \\
\hline
\end{tabular}

De eigen/verwante richting betreft de opleidingsrichting dat door de werkgever voor deze functie minimaal vereist is. 
Bijlage 4: Kernindicatoren

Kernindicatoren 1999-2010

\begin{tabular}{|c|c|c|c|c|c|c|c|c|c|c|c|c|c|}
\hline & & 1999 & 2000 & 2001 & 2002 & 2003 & 2004 & 2005 & 2006 & 2007 & 2008 & 2009 & 2010 \\
\hline \multicolumn{14}{|c|}{ Zelfde opleiding opnieuw kiezen } \\
\hline AVO & $\%$ & 82 & 83 & 81 & - & - & - & - & - & 96 & 97 & 96 & 95 \\
\hline VMBO & $\%$ & 79 & 79 & 80 & 76 & 86 & 84 & 85 & 88 & 84 & 81 & 82 & 84 \\
\hline BOL 1 & $\%$ & 65 & 55 & 69 & 68 & 55 & 60 & 63 & 66 & 61 & 67 & 68 & 72 \\
\hline BOL 2 & $\%$ & 66 & 72 & 63 & 64 & 73 & 62 & 60 & 67 & 64 & 69 & 73 & 75 \\
\hline BOL 3 & $\%$ & 72 & 74 & 77 & 72 & 79 & 76 & 71 & 74 & 75 & 76 & 77 & 79 \\
\hline BOL 4 & $\%$ & 80 & 81 & 79 & 78 & 82 & 77 & 78 & 77 & 80 & 78 & 79 & 79 \\
\hline BBL 1 & $\%$ & - & - & - & - & - & - & - & - & 61 & 64 & 87 & 75 \\
\hline BBL 2 & $\%$ & - & - & - & - & - & - & - & - & 74 & 77 & 84 & 81 \\
\hline BBL 3 & $\%$ & - & - & - & - & - & - & - & - & 81 & 84 & 83 & 85 \\
\hline BBL 4 & $\%$ & - & - & - & - & - & - & - & - & 80 & 82 & 84 & 83 \\
\hline HBO & $\%$ & 78 & 77 & 77 & 76 & 81 & 78 & 78 & 78 & 80 & 78 & 78 & 79 \\
\hline Wo & $\%$ & 81 & 82 & 80 & 80 & 83 & 81 & 81 & 82 & 83 & 83 & 86 & $x$ \\
\hline
\end{tabular}

$\%$ schoolverlaters dat achteraf bezien dezelfde opleiding opnieuw zal kiezen.

- niet gevraagd

* te weinig waarnemingen

$X$ voor 2010 niet beschikbaar 
Statistische Bijlage Tabellen naar opleidingssector 



\title{
Inhoud
}

\author{
Bladzijde
}

\section{Algemeen}

I Aantallen en respons

2 De uitstroom van schoolverlaters verbijzonderd naar geslacht, etniciteit en gemiddelde leeftijd op moment van enquête

\section{Oordeel over gevolgde opleiding}

4 Oordeel van gediplomeerde schoolverlaters: breedte en diepgang van gevolgde opleiding

5 Oordeel van gediplomeerde schoolverlaters: basis te starten op de arbeidsmarkt en basis om kennis en vaardigheden verder te ontwikkelen Oordeel van gediplomeerde schoolverlaters: moeilijkheidsgraad van gevolgde opleiding

$7 \quad$ Oordeel van gediplomeerde schoolverlaters: strenge beoordeling van studenten

\section{Vervolgonderwijs}

II Doorstroom en type vervolgonderwijs

I2 Oordeel van schoolverlaters over de aansluiting van de afgelopen opleiding met de vervolgopleiding

I3 Uitvallers en studiewisselaars

\section{Arbeidsmarkt}

I4 Werkloosheid

I5 Werkloosheid tot eerste baan

I6 Werkzaam in klein-, midden-, grootbedrijf

I7 Percentage werkende schoolverlaters met een flexibele aanstelling

I8 Percentage werkende schoolverlaters met een deeltijdaanstelling en wekelijkse arbeidsduur

I9 Aard van het dienstverband van werkende schoolverlaters $\quad$ I53

20 Vereist opleidingsniveau voor de huidige functie volgens de werkgever 
23 Beloning van werkende schoolverlaters $\quad$ I6I

$24 \quad$ Tevredenheid met huidige functie $\quad$ I63

25 Percentage werkende schoolverlaters waarvan huidige functie goede
carriereperspectieven biedt

$26 \quad$ Benutting van kennis en vaardigheden schieten tekort $\quad$ I67

27 Percentage werkende schoolverlaters dat op zoek is naar een andere baan $\quad$ I69

Teuredenheid achteraf

28 Opleiding achteraf opnieuw kiezen I7I 
Tabel 1

Aantallen en respons

\begin{tabular}{|c|c|c|c|c|}
\hline & benaderde aantallen & responspercentage & ongewogen aantallen ${ }^{1)}$ & gewogen aantallen \\
\hline HAVO/VWO & 3.603 & 38 & 1.358 & 74.806 \\
\hline HAVO & 1.922 & 35 & 667 & 40.713 \\
\hline vwo & 1.681 & 41 & 691 & 34.093 \\
\hline VMBO & 10.519 & 28 & 2.969 & 85.005 \\
\hline \multicolumn{5}{|l|}{ Naar leerweg } \\
\hline Theoretisch & 3.189 & 31 & 990 & 30.472 \\
\hline Gemengd & 779 & 36 & 282 & 4.059 \\
\hline Kaderberoepsgericht & 3.224 & 29 & 947 & 18.675 \\
\hline Basisberoepsgericht & 3.327 & 23 & 750 & 31.800 \\
\hline \multicolumn{5}{|l|}{ Naar sector } \\
\hline Landbouw & 3.292 & 28 & 937 & 9.483 \\
\hline Techniek & 1.245 & 22 & 275 & 15.712 \\
\hline Economie & 1.399 & 24 & 340 & 12.263 \\
\hline Gezondheidszorg & 1.394 & 31 & 427 & 17.076 \\
\hline MBO & 29.083 & 22 & 6.474 & 138.816 \\
\hline BOL & 19.611 & 24 & 4.603 & 82.328 \\
\hline BOL niveau 1 & 992 & 17 & 170 & 4.934 \\
\hline Landbouw & 52 & 15 & 8 & 136 \\
\hline Techniek & 124 & 22 & 27 & 1.017 \\
\hline Economie & 723 & 15 & 111 & 3.123 \\
\hline Gezondheidszorg & 93 & 27 & 24 & 658 \\
\hline BOL niveau 2 & 4.290 & 20 & 867 & 19.506 \\
\hline Landbouw & 324 & 23 & 74 & 961 \\
\hline Techniek & 850 & 16 & 138 & 4.119 \\
\hline Economie & 1.840 & 21 & 386 & 8.041 \\
\hline Gezondheidszorg & 1.276 & 21 & 269 & 6.385 \\
\hline BOL niveau 3 & 4.013 & 23 & 938 & 16.770 \\
\hline Landbouw & 354 & 30 & 106 & 1.175 \\
\hline Techniek & 260 & 24 & 62 & 1.479 \\
\hline Economie & 1.346 & 18 & 248 & 4.913 \\
\hline Gezondheidszorg & 898 & 26 & 235 & 4.148 \\
\hline Gedrag en maatschappij & 1.155 & 25 & 287 & 5.056 \\
\hline BOL niveau 4 & 10.316 & 26 & 2.628 & 41.118 \\
\hline Landbouw & 574 & 36 & 206 & 1.952 \\
\hline Techniek & 2.267 & 24 & 535 & 9.689 \\
\hline Economie & 3.808 & 23 & 870 & 12.976 \\
\hline Gezondheidszorg & 1.420 & 29 & 416 & 6.818 \\
\hline Gedrag en maatschappij & 2.247 & 27 & 601 & 9.682 \\
\hline
\end{tabular}


Tabel 1

Aantallen en respons

\begin{tabular}{|c|c|c|c|c|}
\hline & benaderde aantallen & responspercentage & ongewogen aantallen ${ }^{1)}$ & gewogen aantallen \\
\hline BBL & 9.472 & 20 & 1.871 & 56.488 \\
\hline BBL niveau 1 & 938 & 16 & 149 & 4.948 \\
\hline Landbouw & 409 & 16 & 67 & 1.624 \\
\hline Techniek & 244 & 11 & 28 & 1.363 \\
\hline Economie & 239 & 18 & 42 & 1.557 \\
\hline Gezondheidszorg & 46 & 26 & 12 & 405 \\
\hline BBL niveau 2 & 3.685 & 18 & 644 & 23.476 \\
\hline Landbouw & 446 & 22 & 98 & 1.958 \\
\hline Techniek & 1.911 & 15 & 289 & 12.521 \\
\hline Economie & 867 & 18 & 154 & 5.469 \\
\hline Gezondheidszorg & 461 & 22 & 103 & 3.529 \\
\hline BBL niveau 3 & 3.130 & 21 & 661 & 17.959 \\
\hline Landbouw & 258 & 23 & 59 & 1.084 \\
\hline Techniek & 1.095 & 17 & 185 & 6.574 \\
\hline Economie & 774 & 20 & 158 & 3.849 \\
\hline Gezondheidszorg & 762 & 25 & 189 & 4.643 \\
\hline Gedrag en maatschappij & 241 & 29 & 70 & 1.810 \\
\hline BBL niveau 4 & 1.719 & 24 & 417 & 10.105 \\
\hline Landbouw & 104 & 27 & 28 & 397 \\
\hline Techniek & 333 & 22 & 74 & 2.087 \\
\hline Economie & 542 & 17 & 92 & 2.104 \\
\hline Gezondheidszorg & 405 & 30 & 121 & 2.988 \\
\hline Gedrag en maatschappij & 335 & 30 & 102 & 2.529 \\
\hline HBO & 40.882 & 38 & 14.861 & 49.506 \\
\hline Landbouw & 1.146 & 44 & 481 & 1.439 \\
\hline Onderwijs & 4.266 & 38 & 1.557 & 6.794 \\
\hline Techniek & 6.768 & 41 & 2.679 & 8.416 \\
\hline Economie & 17.118 & 36 & 5.863 & 19.021 \\
\hline Gezondheidszorg & 4.001 & 40 & 1.545 & 4.795 \\
\hline Gedrag en maatschappij & 4.363 & 39 & 1.663 & 5.864 \\
\hline Taal en cultuur & 3.220 & 36 & 1.073 & 3.178 \\
\hline Totaal & 84.087 & 31 & 25.662 & 348.132 \\
\hline
\end{tabular}

Bron: ROA (SIS) 
Tabel 2

De uitstroom van schoolverlaters verbijzonderd naar geslacht, etniciteit en gemiddelde leeftijd op moment van enquête

\begin{tabular}{|c|c|c|c|c|c|}
\hline \multirow[t]{2}{*}{ Opleidingssector } & vrouw & $\begin{array}{l}\text { westerse } \\
\text { allochtoon }\end{array}$ & $\begin{array}{l}\text { niet-westerse } \\
\text { allochtoon }\end{array}$ & autochtoon & \multirow[t]{2}{*}{$\begin{array}{l}\text { leeftijd } \\
\text { gem. }\end{array}$} \\
\hline & $\%$ & $\%$ & $\%$ & $\%$ & \\
\hline HAVO/VWO & 53 & 6 & 6 & 88 & 18,8 \\
\hline HAVO & 52 & 5 & 6 & 89 & 18,6 \\
\hline vwo & 55 & 6 & 7 & 87 & 19,2 \\
\hline VMBO & 48 & 5 & 11 & 84 & 17,5 \\
\hline \multicolumn{6}{|l|}{ Naar leerweg } \\
\hline Theoretisch & 49 & 4 & 11 & 85 & 17,4 \\
\hline Gemengd & 52 & 2 & 3 & 95 & 17,3 \\
\hline Kaderberoepsgericht & 48 & 6 & 8 & 86 & 17,5 \\
\hline Basisberoepsgericht & 44 & 5 & 15 & 80 & 17,6 \\
\hline \multicolumn{6}{|l|}{ Naar sector } \\
\hline Landbouw & 48 & 3 & 3 & 94 & 17,6 \\
\hline Techniek & 3 & 4 & 10 & 86 & 17,6 \\
\hline Economie & 45 & 11 & 16 & 73 & 17,5 \\
\hline Gezondheidszorg & 88 & 4 & 14 & 82 & 17,5 \\
\hline MBO & 49 & 5 & 14 & 81 & 25,8 \\
\hline BOL & 56 & 5 & 17 & 78 & 22,2 \\
\hline BOL niveau 1 & 47 & 7 & 44 & 49 & 23,2 \\
\hline BOL niveau 2 & 51 & 5 & 27 & 67 & 21,4 \\
\hline Landbouw & 44 & 1 & 5 & 93 & 21,3 \\
\hline Techniek & 12 & 7 & 29 & 64 & 22,3 \\
\hline Economie & 42 & 4 & 33 & 63 & 20,5 \\
\hline Gezondheidszorg & 90 & 6 & 23 & 71 & 21,8 \\
\hline BOL niveau 3 & 64 & 5 & 13 & 82 & 22,3 \\
\hline Landbouw & 43 & 5 & 1 & 94 & 20,7 \\
\hline Techniek & 15 & 9 & 10 & 80 & 21,8 \\
\hline Economie & 35 & 6 & 22 & 72 & 21,7 \\
\hline Gezondheidszorg & 88 & 2 & 6 & 92 & 22,7 \\
\hline Gedrag en maatschappij & 92 & 7 & 14 & 79 & 23,2 \\
\hline BOL niveau 4 & 56 & 4 & 11 & 84 & 22,3 \\
\hline Landbouw & 59 & 2 & 2 & 96 & 21,8 \\
\hline Techniek & 24 & 5 & 6 & 89 & 22,2 \\
\hline Economie & 43 & 5 & 18 & 77 & 21,8 \\
\hline Gezondheidszorg & 80 & 4 & 9 & 87 & 23,3 \\
\hline Gedrag en maatschappij & 87 & 4 & 10 & 86 & 22,6 \\
\hline
\end{tabular}


Tabel 2

De uitstroom van schoolverlaters verbijzonderd naar geslacht, etniciteit en gemiddelde leeftijd op moment van enquête

\begin{tabular}{|c|c|c|c|c|c|}
\hline \multirow[t]{2}{*}{ Opleidingssector } & vrouw & $\begin{array}{r}\text { westerse } \\
\text { allochtoon }\end{array}$ & $\begin{array}{l}\text { niet-westerse } \\
\text { allochtoon }\end{array}$ & autochtoon & \multirow[t]{2}{*}{$\begin{array}{l}\text { leeftijo } \\
\text { gem }\end{array}$} \\
\hline & $\%$ & $\%$ & $\%$ & $\%$ & \\
\hline BBL & 39 & 5 & 9 & 85 & 31,0 \\
\hline BBL niveau 1 & 32 & 3 & 19 & 77 & 35,1 \\
\hline BBL niveau 2 & 28 & 6 & 10 & 84 & 30,1 \\
\hline Landbouw & 18 & 4 & 4 & 92 & 31,9 \\
\hline Techniek & 6 & 4 & 9 & 88 & 26,0 \\
\hline Economie & 41 & 10 & 14 & 77 & 31,6 \\
\hline Gezondheidszorg & 93 & 9 & 14 & 77 & 41,5 \\
\hline BBL niveau 3 & 45 & 5 & 8 & 86 & 30,3 \\
\hline Landbouw & 13 & 7 & 1 & 93 & 29,4 \\
\hline Techniek & 2 & 3 & 7 & 90 & 27,1 \\
\hline Economie & 48 & 6 & 7 & 87 & 26,5 \\
\hline Gezondheidszorg & 95 & 6 & 8 & 87 & 35,7 \\
\hline Gedrag en maatschappij & 89 & 11 & 23 & 65 & 36,6 \\
\hline BBL niveau 4 & 56 & 5 & 3 & 91 & 32,4 \\
\hline Landbouw & 26 & 7 & 0 & 93 & 30,1 \\
\hline Techniek & 17 & 6 & 1 & 92 & 30,6 \\
\hline Economie & 41 & 5 & 3 & 92 & 27,3 \\
\hline Gezondheidszorg & 86 & 5 & 3 & 93 & 33,1 \\
\hline Gedrag en maatschappij & 70 & 6 & 6 & 88 & 37,8 \\
\hline HBO & 56 & 7 & 7 & 85 & 24,9 \\
\hline Landbouw & 44 & 6 & 2 & 92 & 24,7 \\
\hline Onderwijs & 79 & 4 & 3 & 93 & 25,6 \\
\hline Techniek & 13 & 5 & 7 & 88 & 24,9 \\
\hline Economie & 50 & 8 & 10 & 82 & 24,6 \\
\hline Gezondheidszorg & 82 & 7 & 4 & 89 & 24,7 \\
\hline Gedrag en maatschappij & 88 & 6 & 10 & 84 & 24,9 \\
\hline Taal en cultuur & 59 & 20 & 6 & 74 & 26,8 \\
\hline Totaal & 50 & 5 & 11 & 84 & 22,1 \\
\hline
\end{tabular}

Bron: ROA (SIS)

\section{Toelichting}

Het betreft de leeftijd per onderzoeksdatum ongeveer anderhalf jaar na schoolverlaten. 
Tabel 3

Situatie op moment van enquête

\begin{tabular}{|c|c|c|c|c|}
\hline \multirow[t]{2}{*}{ Opleidingssector } & studie & $\begin{array}{r}\text { combinatie } \\
\text { werken-leren }\end{array}$ & betaald werk & anders \\
\hline & $\%$ & $\%$ & $\%$ & $\%$ \\
\hline HAVO/VWO & 81 & 14 & 3 & 2 \\
\hline HAVO & 76 & 16 & 5 & 2 \\
\hline VWo & 87 & 11 & 1 & 1 \\
\hline VMBO & 63 & 30 & 5 & 2 \\
\hline \multicolumn{5}{|l|}{ Naar leerweg } \\
\hline Theoretisch & 74 & 22 & 2 & 2 \\
\hline Gemengd & 76 & 21 & 2 & 1 \\
\hline Kaderberoepsgericht & 67 & 28 & 3 & 2 \\
\hline Basisberoepsgericht & 49 & 39 & 10 & 2 \\
\hline \multicolumn{5}{|l|}{ Naar sector } \\
\hline Landbouw & 57 & 36 & 6 & 1 \\
\hline Techniek & 40 & 46 & 12 & 2 \\
\hline Economie & 57 & 35 & 7 & 1 \\
\hline Gezondheidszorg & 74 & 22 & 3 & 1 \\
\hline MBO & 27 & 19 & 48 & 6 \\
\hline BOL & 42 & 15 & 37 & 6 \\
\hline BOL niveau 1 & 40 & 29 & 20 & 11 \\
\hline BOL niveau 2 & 44 & 19 & 30 & 7 \\
\hline Landbouw & 30 & 27 & 36 & 6 \\
\hline Techniek & 45 & 16 & 29 & 10 \\
\hline Economie & 42 & 20 & 33 & 5 \\
\hline Gezondheidszorg & 47 & 19 & 26 & 8 \\
\hline BOL niveau 3 & 34 & 14 & 47 & 5 \\
\hline Landbouw & 26 & 17 & 51 & 6 \\
\hline Techniek & 28 & 17 & 46 & 9 \\
\hline Economie & 48 & 17 & 28 & 6 \\
\hline Gezondheidszorg & 27 & 15 & 56 & 2 \\
\hline Gedrag en maatschappij & 29 & 9 & 58 & 4 \\
\hline BOL niveau 4 & 45 & 13 & 37 & 5 \\
\hline Landbouw & 42 & 13 & 41 & 5 \\
\hline Techniek & 47 & 12 & 36 & 6 \\
\hline Economie & 52 & 16 & 28 & 4 \\
\hline Gezondheidszorg & 35 & 13 & 49 & 3 \\
\hline Gedrag en maatschappij & 44 & 10 & 41 & 6 \\
\hline
\end{tabular}


Tabel 3

Situatie op moment van enquête

\begin{tabular}{|c|c|c|c|c|}
\hline \multirow[t]{2}{*}{ Opleidingssector } & studie & $\begin{array}{r}\text { combinatie } \\
\text { werken-leren }\end{array}$ & betaald werk & anders \\
\hline & $\%$ & $\%$ & $\%$ & $\%$ \\
\hline BBL & 4 & 25 & 64 & 7 \\
\hline BBL niveau 1 & 4 & 28 & 62 & 6 \\
\hline BBL niveau 2 & 4 & 29 & 60 & 8 \\
\hline Landbouw & 3 & 20 & 68 & 8 \\
\hline Techniek & 3 & 37 & 53 & 6 \\
\hline Economie & 5 & 20 & 65 & 10 \\
\hline Gezondheidszorg & 3 & 15 & 74 & 9 \\
\hline BBL niveau 3 & 3 & 22 & 69 & 6 \\
\hline Landbouw & 1 & 13 & 83 & 4 \\
\hline Techniek & 3 & 30 & 63 & 3 \\
\hline Economie & 7 & 22 & 61 & 10 \\
\hline Gezondheidszorg & 2 & 15 & 77 & 7 \\
\hline Gedrag en maatschappij & 0 & 15 & 84 & 2 \\
\hline BBL niveau 4 & 4 & 23 & 66 & 7 \\
\hline Landbouw & 2 & 11 & 79 & 7 \\
\hline Techniek & 0 & 34 & 65 & 1 \\
\hline Economie & 13 & 23 & 54 & 9 \\
\hline Gezondheidszorg & 2 & 21 & 71 & 6 \\
\hline Gedrag en maatschappij & 2 & 18 & 69 & 11 \\
\hline HBO & 18 & $\mathbf{x}$ & 70 & 11 \\
\hline Landbouw & 20 & $x$ & 70 & 9 \\
\hline Onderwijs & 8 & $x$ & 78 & 14 \\
\hline Techniek & 23 & $x$ & 70 & 6 \\
\hline Economie & 26 & $x$ & 63 & 11 \\
\hline Gezondheidszorg & 9 & $x$ & 78 & 12 \\
\hline Gedrag en maatschappij & 12 & $x$ & 75 & 13 \\
\hline Taal en cultuur & 9 & $x$ & 78 & 13 \\
\hline Totaal & 46 & 18 & 31 & 5 \\
\hline
\end{tabular}

Bron: ROA (SIS)

$\mathrm{X}=$ vraag niet opgenomen 
Tabel 4

Oordeel van gediplomeerde schoolverlaters: breedte en diepgang van gevolgde opleiding

\begin{tabular}{|c|c|c|c|}
\hline & \multicolumn{2}{|c|}{ Breedte } & \multirow{2}{*}{$\begin{array}{l}\text { Diepgang } \\
\text { te weinig diepgang }\end{array}$} \\
\hline & te smal & te breed & \\
\hline & $\%$ & $\%$ & $\%$ \\
\hline HAVO/VWO & 3 & 7 & 12 \\
\hline HAVO & 3 & 6 & 13 \\
\hline VW0 & 3 & 8 & 12 \\
\hline VMBO & 8 & 9 & 11 \\
\hline \multicolumn{4}{|l|}{ Naar leerweg } \\
\hline Theoretisch & 7 & 8 & 14 \\
\hline Gemengd & 4 & 11 & 9 \\
\hline Kaderberoepsgericht & 7 & 10 & 9 \\
\hline Basisberoepsgericht & 10 & 9 & 9 \\
\hline \multicolumn{4}{|l|}{ Naar sector } \\
\hline Landbouw & 9 & 6 & 10 \\
\hline Techniek & 12 & 9 & 10 \\
\hline Economie & 9 & 9 & 8 \\
\hline Gezondheidszorg & 5 & 13 & 8 \\
\hline MBO & 8 & 10 & 16 \\
\hline BOL & 8 & 11 & 19 \\
\hline BOL niveau 1 & 9 & 10 & 11 \\
\hline BOL niveau 2 & 8 & 10 & 13 \\
\hline Landbouw & 11 & 6 & 14 \\
\hline Techniek & 9 & 8 & 17 \\
\hline Economie & 7 & 11 & 15 \\
\hline Gezondheidszorg & 6 & 10 & 9 \\
\hline BOL niveau 3 & 7 & 10 & 19 \\
\hline Landbouw & 8 & 12 & 18 \\
\hline Techniek & 4 & 9 & 7 \\
\hline Economie & 10 & 12 & 23 \\
\hline Gezondheidszorg & 5 & 7 & 11 \\
\hline Gedrag en maatschappij & 7 & 12 & 25 \\
\hline BOL niveau 4 & 9 & 11 & 23 \\
\hline Landbouw & 10 & 13 & 30 \\
\hline Techniek & 9 & 11 & 21 \\
\hline Economie & 12 & 9 & 21 \\
\hline Gezondheidszorg & 8 & 12 & 22 \\
\hline Gedrag en maatschappij & 7 & 13 & 26 \\
\hline
\end{tabular}




\section{Tabel 4}

Oordeel van gediplomeerde schoolverlaters: breedte en diepgang van gevolgde opleiding

\begin{tabular}{|c|c|c|c|}
\hline & & & Diepgang \\
\hline & te smal & te breed & te weinig diepgang \\
\hline & $\%$ & $\%$ & $\%$ \\
\hline BBL & 7 & 8 & 12 \\
\hline BBL niveau 1 & 3 & 8 & 6 \\
\hline BBL niveau 2 & 9 & 9 & 9 \\
\hline Landbouw & 5 & 7 & 11 \\
\hline Techniek & 12 & 7 & 9 \\
\hline Economie & 3 & 10 & 6 \\
\hline Gezondheidszorg & 11 & 17 & 12 \\
\hline
\end{tabular}

BBL niveau 3
Landbouw
Techniek
Economie
Gezondheidszorg
Gedrag en maatschappij

$\begin{array}{rrr}\mathbf{5} & \mathbf{8} & \mathbf{1 0} \\ 1 & 10 & 11 \\ 5 & 5 & 9 \\ 9 & 7 & 12 \\ 4 & 13 & 10 \\ 9 & 8 & 11\end{array}$

$\begin{array}{lccr}\text { BBL niveau 4 } & \mathbf{7} & \mathbf{8} & \mathbf{2 4} \\ \text { Landbouw } & & 1 & 8 \\ \text { Techniek } & 1 & 9 & 8 \\ \text { Economie } & 14 & 6 & 26 \\ \text { Gezondheidszorg } & 6 & 10 & 33 \\ \text { Gedrag en maatschappij } & 8 & 7 & 30\end{array}$

$\begin{array}{llcl}\text { HBO } & \mathbf{5} & \mathbf{2 4} & \mathbf{2 1} \\ \text { Landbouw } & 6 & 28 & 20 \\ \text { Onderwijs } & 9 & 8 & 21 \\ \text { Techniek } & 4 & 20 & 17 \\ \text { Economie } & 3 & 31 & 23 \\ \text { Gezondheidszorg } & 7 & 19 & 25 \\ \text { Gedrag en maatschappij } & 5 & 29 & 22 \\ & & & \mathbf{1 5}\end{array}$

\section{Toelichting}

Vragen in de enquête:

Wat is uw oordeel over uw gevolgde opleiding met betrekking tot de breedte van de opleiding ( 1 'te weinig' tot 7 'te veel'). Vermeld is percentage van antwoordcategorie 1 en 2 (te smal) en antwoordcategorie 6 en 7 (te breed).

Wat is uw oordeel over uw gevolgde opleiding met betrekking tot de diepgang van de opleiding ( 1 'te weinig' tot 7 'te veel'). Vermeld is percentage van antwoordcategorie 1 en 2 (te weinig). 


\section{Tabel 5}

Oordeel van gediplomeerde schoolverlaters: basis om te starten op de arbeidsmarkt en basis om kennis en vaardigheden verder te ontwikkelen

$\begin{array}{lrr} & \text { verder ontwikkelen } & \text { starten op arbeidsmarkt } \\ & \% & \% \\ \text { VMB0 } & \mathbf{5 8} & \mathbf{2 9} \\ \text { Naar leerweg } & & \\ \text { Theoretisch } & 62 & 25 \\ \text { Gemengd } & 68 & 21 \\ \text { Kaderberoepsgericht } & 57 & 31 \\ \text { Basisberoepsgericht } & 53 & 32\end{array}$

\begin{tabular}{lll}
\hline Naar sector & & 23 \\
Landbouw & 48 & 34 \\
Techniek & 54 & 31 \\
Economie & 59 & 33 \\
Gezondheidszorg & 60 &
\end{tabular}

MBO

61

47

BOL

58

43

BOL niveau 1

58

BOL niveau 2

59

43

Landbouw

55

Techniek

55

Economie

60

Gezondheidszorg

62

42

47

40

44

$\begin{array}{lll}\text { B0L niveau 3 } & \mathbf{6 1} & \mathbf{4 9} \\ \text { Landbouw } & 43 & 35 \\ \text { Techniek } & 64 & 50 \\ \text { Economie } & 54 & 38 \\ \text { Gezondheidszorg } & 69 & 56 \\ \text { Gedrag en maatschappij } & 64 & 56\end{array}$

BOL niveau 4

56

Landbouw

47

Techniek

47

Economie

Gezondheidszorg

52

Gedrag en maatschappij

58 


\section{Tabel 5}

Oordeel van gediplomeerde schoolverlaters: basis om te starten op de arbeidsmarkt en basis om kennis en vaardigheden verder te ontwikkelen

$\begin{array}{rrr} & \text { verder ontwikkelen } & \text { starten op arbeidsmarkt } \\ \% & \%\end{array}$

BBL niveau 1

\section{BBL niveau 2}

61

Landbouw

54

Techniek

64

Economie

54

Gezondheidszorg

69

\begin{tabular}{lll}
\hline BBL niveau 3 & $\mathbf{6 7}$ & $\mathbf{6 0}$ \\
Landbouw & 50 & 46 \\
Techniek & 68 & 60 \\
Economie & 52 & 40 \\
Gezondheidszorg & 83 & 76 \\
Gedrag en maatschappij & 67 & 65
\end{tabular}

\begin{tabular}{lll}
\hline BBL niveau 4 & $\mathbf{6 8}$ & $\mathbf{6 3}$ \\
Landbouw & 74 & 45 \\
Techniek & 75 & 66 \\
Economie & 47 & 47 \\
Gezondheidszorg & 74 & 72 \\
Gedrag en maatschappij & 69 & 68
\end{tabular}

\begin{tabular}{lll} 
HBO & $\mathbf{6 5}$ & $\mathbf{5 1}$ \\
Landbouw & 66 & 52 \\
Onderwijs & 62 & 62 \\
Techniek & 69 & 60 \\
Economie & 63 & 46 \\
Gezondheidszorg & 70 & 63 \\
Gedrag en maatschappij & 63 & 46 \\
Taal en cultuur & 72 & 32 \\
\hline Totaal & & $\mathbf{4 2}$
\end{tabular}

Bron: ROA (SIS)

\section{Toelichting}

In welke mate biedt uw gevolgde opleiding een goede basis om kennis en vaardigheden verder te ontwikkelen ( 1 'helemaal niet' tot 5 'in sterkte mate'). Vermeld is het percentage van antwoordcategorie 4 en 5.

Vraag in de enquête:

In welke mate biedt uw gevolgde opleiding een goede basis om te starten op de arbeidsmarkt ( 1 'helemaal niet' tot 5 'in sterke mate'). Vermeld is het percentage van antwoordcategorie 4 en 5 . 
Tabel 6

Oordeel van gediplomeerde schoolverlaters: moeilijkheidsgraad van opleiding te makkelijk

HAVO/VWO
HAVO
VWO
VMBO
Naar leerweg
Theoretisch
Gemengd
Kaderberoepsgericht
Basisberoepsgericht

10

8

17

3

20

3

14

17

14

Naar sector

Landbouw

Techniek

Economie

Gezondheidszorg

MBO

BOL

BOL niveau 1

Landbouw

Techniek

Economie

Gezondheidszorg

BOL niveau 3

Landbouw

Techniek

Economie

Gezondheidszorg

Gedrag en maatschappij

BOL niveau 4

Landbouw

Techniek

Economie

Gezondheidszorg

Gedrag en maatschappij
19

7

22

11

8

14

15

19

15

9

29

3

16

15

6

15 


\section{Tabel 6}

Oordeel van gediplomeerde schoolverlaters: moeilijkheidsgraad van opleiding

BBL

14

\section{BBL niveau 1}

9

$\begin{array}{lrr}\text { BBL niveau 2 } & \mathbf{1 3} & \mathbf{9} \\ \text { Landbouw } & 14 & 7 \\ \text { Techniek } & 14 & 7 \\ \text { Economie } & 6 & 11 \\ \text { Gezondheidszorg } & 16 & 12\end{array}$

BBL niveau 3

Landbouw

Techniek

13

15

Economie

Gezondheidszorg

Gedrag en maatschappij

\section{BBL niveau 4}

Landbouw

Techniek

Economie

Gezondheidszorg

Gedrag en maatschappij

Landbouw

Bron: ROA (SIS)

\section{Toelichting}

Vraag in de enquête:

Wat is uw oordeel over uw gevolgde opleiding met betrekking tot de moeilijkheidsgraad van de opleiding ( 1 'veel te laag' tot 7 'veel te hoog'). Vermeld is het percentage van antwoordcategorie 1 en 2 (te makkelijk) en 6 en 7 (te moeilijk). 
Tabel 7

Oordeel van gediplomeerde schoolverlaters: docenten streng in beoordeling studenten

\begin{tabular}{|c|c|c|}
\hline & (helemaal) mee eens & (helemaal) mee oneens \\
\hline & $\%$ & $\%$ \\
\hline HAVO/VWO & 27 & 28 \\
\hline HAVO & 26 & 27 \\
\hline VW0 & 27 & 31 \\
\hline VMBO & 21 & 32 \\
\hline Naar leerweg & & \\
\hline Theoretisch & 23 & 30 \\
\hline Gemengd & 17 & 33 \\
\hline Kaderberoepsgericht & 22 & 31 \\
\hline Basisberoepsgericht & 19 & 35 \\
\hline
\end{tabular}

\begin{tabular}{|c|c|c|}
\hline \multicolumn{3}{|l|}{ Naar sector } \\
\hline Landbouw & 21 & 31 \\
\hline Techniek & 17 & 34 \\
\hline Economie & 25 & 32 \\
\hline Gezondheidszorg & 20 & 35 \\
\hline MBO & 18 & 42 \\
\hline BOL & 18 & 43 \\
\hline BOL niveau 1 & 17 & 34 \\
\hline BOL niveau 2 & 21 & 36 \\
\hline Landbouw & 10 & 50 \\
\hline Techniek & 12 & 43 \\
\hline Economie & 25 & 33 \\
\hline Gezondheidszorg & 23 & 32 \\
\hline B0L niveau 3 & 19 & 43 \\
\hline Landbouw & 17 & 40 \\
\hline Techniek & 21 & 44 \\
\hline Economie & 20 & 46 \\
\hline Gezondheidszorg & 23 & 35 \\
\hline Gedrag en maatschappij & 14 & 48 \\
\hline B0L niveau 4 & 16 & 48 \\
\hline Landbouw & 6 & 51 \\
\hline Techniek & 19 & 47 \\
\hline Economie & 16 & 45 \\
\hline Gezondheidszorg & 17 & 44 \\
\hline Gedrag en maatschappij & 15 & 54 \\
\hline
\end{tabular}




\section{Tabel 7}

Oordeel van gediplomeerde schoolverlaters: docenten streng in beoordeling studenten

$\begin{array}{rrr}\text { (helemaal) mee eens } & \text { (helemaal) mee oneens } \\ \% & \%\end{array}$

BBL

\section{BBL niveau 1}

20

\section{BBL niveau 2}

20

40

Landbouw

Techniek

Economie

Gezondheidszorg

28

\section{BBL niveau 3}

Techniek

Economie

\section{BBL niveau 4}

Landbouw

Bron: ROA (SIS)

\section{Toelichting}

Vraag in de enquête:

De docenten waren streng in de beoordeling van cursisten ( 1 'helemaal mee oneens' tot 5 'helemaal mee eens'). Vermeld is het percentage van antwoordcategorie 4 en 5 (helemaal mee eens) en 1 en 2 (helemaal mee oneens). 
Tabel 8

Oordeel van gediplomeerde schoolverlaters: uitdagend niveau

HAVO/VWO
HAVO
VW0
VMBO
Naarleerweg
Theoretisch
Gemengd
Kaderberoepsgericht
Basisberoepsgericht

38

35

30

36

27

28

31

32

Naar sector

Landbouw

Techniek

Economie

Gezondheidszorg

MBO

BOL

BOL niveau 1

BOL niveau 2

Landbouw

Techniek

Economie

Gezondheidszorg

BOL niveau 3

Landbouw

Techniek

Economie

Gezondheidszorg

Gedrag en maatschappi

BOL niveau 4

Landbouw

Techniek

Economie

Gezondheidszorg

Gedrag en maatschappij
31

40

41

23

39

22

30

42

43

27

21

6

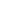

.




\section{Tabel 8}

Oordeel van gediplomeerde schoolverlaters: uitdagend niveau

$\begin{array}{rr}\text { (helemaal) mee eens } & \text { (helemaal) mee oneens } \\ \% & \%\end{array}$

BBL

\section{BBL niveau 1}

50

\section{BBL niveau 2}

Landbouw

Techniek

Economie

Gezondheidszorg

$\begin{array}{ll}35 & 27 \\ 29 & 19 \\ 31 & 29 \\ 39 & 29 \\ 51 & 21\end{array}$

BBL niveau 3

37

25

Landbouw

Techniek

Economie

Gezondheidszorg

Gedrag en maatschappij

37
16

38

28

43

45
33

81

Landbouw

Techniek

Economie

Gezondheidszorg

Gedrag en maatschappij

\section{HBO}

Landbouw

Onderwijs

Techniek

Economie

Gezondheidszorg

Gedrag en maatschappij

\section{Totaal}

Bron: ROA (SIS)

\section{Toelichting}

Vraag in de enquête:

De opleiding was uitdagend met betrekking tot niveau (1'helemaal mee oneens' tot 5 'helemaal mee eens'). Vermeld is het percentage van antwoordcategorie 4 en 5 (helemaal mee eens) en 1 en 2 (helemaal mee oneens). 
Tabel 9

Oordeel van gediplomeerde schoolverlaters: pittige examens/opdrachten

HAVO/VWO
HAVO
VWO
VMBO
Naarleerweg
Theoretisch
Gemengd
Kaderberoepsgericht
Basisberoepsgericht

36

39

24

22

Naar sector

Landbouw

Techniek

Gezondheidszorg
BOL

22

\section{BOL niveau 1}

\section{1} 25

\section{BOL niveau 2}

32

Landbouw

Techniek

Economie

BOL niveau 3

Landbouw

Techniek

Economie Gezondheidszorg

Gedrag en maatschappij

\section{BOL niveau 4}

Techniek

Economie

\section{7} 1 


\section{Tabel 9}

Oordeel van gediplomeerde schoolverlaters: pittige examens/opdrachten

BBL

\section{BBL niveau 1}

33

$\begin{array}{ll}\text { BBL niveau 2 } & 28 \\ \text { Landbouw } & 20 \\ \text { Techniek } & 27 \\ \text { Economie } & 30 \\ \text { Gezondheidszorg } & 36\end{array}$

$28 \quad 31$

$20 \quad 36$

$27-31$

30

$36 \quad 26$

BBL niveau 3

32

Landbouw

11

Techniek

Economie

Gezondheidszorg

Gedrag en maatschappij

\section{BBL niveau 4}

Economie

Landbouw

Techniek

\section{Toelichting}

Vraag in de enquête:

De examens/opdrachten waren over het algemeen zeer pittig ( 1 'helemaal mee oneens' tot 5 'helemaal mee eens'). Vermeld is het percentage van antwoordcategorie 4 en 5 (helemaal mee eens) en 1 en 2 (helemaal mee oneens). 
Tabel 10

Oordeel van gediplomeerde schoolverlaters: toetsen op inzicht

HAVO/VWO
HAVO
VW0
VMBO
Naar leerweg
Theoretisch
Gemengd
Kaderberoepsgericht
Basisberoepsgericht

43

Naar sector

Landbouw

Techniek

Economie

Gezondheidszorg

BOL

34

BOL niveau 1

43

20

BOL niveau 2

41

Landbouw

Techniek

25

40

Economie

Gezondheidszorg

40

21

BOL niveau 3

33

30

Landbouw

39

Techniek

Economie

Gezondheidszorg

Gedrag en maatschappij

BOL niveau 4

Landbouw

Techniek

Economie

Gezondheidszorg

Gedrag en maatschappij 


\section{Tabel 10}

Oordeel van gediplomeerde schoolverlaters: toetsen op inzicht

BBL

44

BBL niveau 1

61

$\begin{array}{lr}\text { BBL niveau 2 } & 41 \\ \text { Landbouw } & 40 \\ \text { Techniek } & 41 \\ \text { Economie } & 38 \\ \text { Gezondheidszorg } & 47\end{array}$

$41 \quad 24$

40

Gezondheidszorg

47

BBL niveau 3

Techniek

Economie

\section{BBL niveau 4}

Landbouw

Techniek

Economie

Landbouw

Techniek

Economie

Bron: ROA (SIS)

\section{Toelichting}

Vraag in de enquête:

In de opleiding werd voldoende getoetst op inzicht ( 1 'helemaal mee oneens' tot 5 'helemaal mee eens'). Vermeld is het percentage van antwoordcategorie 4 en 5 (helemaal mee eens) en 1 en 2 (helemaal mee oneens). 
Tabel 11

Doorstroom en type vervolgonderwijs

\begin{tabular}{|c|c|c|c|c|c|c|c|c|c|}
\hline & \multirow[b]{2}{*}{$\begin{array}{r}\text { Vervolgopleiding } \\
\text { gevolgd }\end{array}$} & \multicolumn{8}{|c|}{ Vervolgopleiding niveau } \\
\hline & & HAVO/VWO & $\begin{array}{c}\text { BOL } \\
\text { niv. } \\
1 / 2\end{array}$ & $\begin{array}{c}\text { BOL } \\
\text { niv. } \\
3 / 4\end{array}$ & $\begin{array}{l}\text { BBL } \\
\text { niv. } \\
1 / 2\end{array}$ & $\begin{array}{l}\text { BBL } \\
\text { niv. } \\
3 / 4\end{array}$ & $\mathrm{HBO}$ & wo & anders \\
\hline & $\%$ & $\%$ & $\%$ & $\%$ & $\%$ & $\%$ & $\%$ & $\%$ & $\%$ \\
\hline HAVO/VWO & 87 & 0 & 0 & 2 & 0 & 0 & 49 & 34 & 1 \\
\hline HAVO & 86 & 0 & 0 & 3 & 0 & 1 & 79 & 1 & 1 \\
\hline vw0 & 88 & 0 & 0 & 0 & 0 & 0 & 14 & 73 & 1 \\
\hline VMBO & 96 & 4 & 23 & 52 & 12 & 4 & 0 & 0 & 2 \\
\hline Naar leerweg & & & & & & & & & \\
\hline Theoretisch & 97 & 10 & 2 & 79 & 2 & 4 & 0 & 0 & 1 \\
\hline Gemengd & 98 & 2 & 7 & 84 & 0 & 4 & 0 & 0 & 0 \\
\hline Kaderberoepsgericht & 98 & 0 & 7 & 76 & 8 & 5 & 0 & 0 & 2 \\
\hline Basisberoepsgericht & 95 & 0 & 55 & 7 & 25 & 4 & 0 & 0 & 2 \\
\hline
\end{tabular}

\begin{tabular}{|c|c|c|c|c|c|c|c|c|c|}
\hline Naar sector & & & & & & & & & \\
\hline Landbouw & 96 & 1 & 38 & 38 & 14 & 3 & 0 & 0 & 1 \\
\hline Techniek & 95 & 0 & 23 & 29 & 33 & 6 & 0 & 0 & 3 \\
\hline Economie & 98 & 1 & 40 & 40 & 9 & 6 & 0 & 0 & 2 \\
\hline Gezondheidszorg & 96 & 0 & 41 & 39 & 12 & 1 & 0 & 0 & 1 \\
\hline MBO & 45 & 0 & 2 & 12 & 2 & 10 & 21 & 0 & 1 \\
\hline BOL & 56 & 0 & 3 & 16 & 1 & 4 & 29 & 0 & 1 \\
\hline BOL niveau 1 & 67 & 0 & 31 & 10 & 16 & 5 & 3 & 0 & 1 \\
\hline BOL niveau 2 & 58 & 0 & 3 & 40 & 1 & 9 & 2 & 0 & 1 \\
\hline Landbouw & 52 & 0 & 3 & 34 & 2 & 14 & 0 & 0 & 0 \\
\hline Techniek & 60 & 0 & 4 & 37 & 2 & 13 & 1 & 0 & 2 \\
\hline Economie & 52 & 0 & 3 & 36 & 1 & 6 & 3 & 0 & 2 \\
\hline Gezondheidszorg & 65 & 0 & 3 & 48 & 1 & 11 & 1 & 0 & 0 \\
\hline
\end{tabular}

$\begin{array}{lrrrrrrrrr}\text { B0L niveau 3 } & \mathbf{4 8} & \mathbf{0} & \mathbf{1} & \mathbf{2 4} & \mathbf{0} & \mathbf{6} & \mathbf{1 4} & \mathbf{0} & \mathbf{2} \\ \text { Landbouw } & 45 & 0 & 2 & 27 & 0 & 11 & 1 & 0 & 3 \\ \text { Techniek } & 43 & 0 & 1 & 23 & 0 & 7 & 8 & 0 & 3 \\ \text { Economie } & 64 & 0 & 1 & 30 & 0 & 4 & 26 & 0 & 1 \\ \text { Gezondheidszorg } & 40 & 0 & 0 & 25 & 0 & 5 & 7 & 0 & 2 \\ \text { Gedrag en maatschappij } & 42 & 0 & 0 & 19 & 0 & 6 & 12 & 0 & 3\end{array}$

$\begin{array}{llllllllll}\text { B0L niveau 4 } & \mathbf{5 7} & \mathbf{0} & \mathbf{0} & \mathbf{2} & \mathbf{0} & \mathbf{1} & \mathbf{5 2} & \mathbf{0} & \mathbf{1} \\ \text { Landbouw } & 53 & 0 & 0 & 5 & 0 & 1 & 46 & 0 & 2 \\ \text { Techniek } & 56 & 0 & 0 & 3 & 0 & 1 & 50 & 0 & 1 \\ \text { Economie } & 65 & 0 & 0 & 2 & 0 & 2 & 59 & 0 & 1 \\ \text { Gezondheidszorg } & 45 & 0 & 0 & 1 & 0 & 0 & 43 & 0 & 0 \\ \text { Gedrag en maatschappij } & 56 & 0 & 0 & 3 & 0 & 1 & 52 & 0 & 1\end{array}$


Tabel 11

Doorstroom en type vervolgonderwijs

\begin{tabular}{|c|c|c|c|c|c|c|c|c|c|}
\hline & \multirow[b]{2}{*}{$\begin{array}{r}\text { Vervolgopleiding } \\
\text { gevolgd }\end{array}$} & \multicolumn{8}{|c|}{ Vervolgopleiding niveau } \\
\hline & & HAVO/VWO & $\begin{array}{c}\text { BOL } \\
\text { niv. } \\
1 / 2\end{array}$ & $\begin{array}{l}\text { BOL } \\
\text { niv. } \\
3 / 4\end{array}$ & $\begin{array}{l}\text { BBL } \\
\text { niv. } \\
1 / 2\end{array}$ & $\begin{array}{l}\text { BBL } \\
\text { niv. } \\
3 / 4\end{array}$ & HBO & W0 & anders \\
\hline & $\%$ & $\%$ & $\%$ & $\%$ & $\%$ & $\%$ & $\%$ & $\%$ & $\%$ \\
\hline BBL & 29 & 0 & 1 & 3 & 3 & 21 & 4 & 0 & 2 \\
\hline BBL niveau 1 & 29 & 0 & 4 & 0 & 13 & 3 & 1 & 0 & 5 \\
\hline BBL niveau 2 & 34 & 0 & 0 & 4 & 1 & 27 & 1 & 0 & 1 \\
\hline Landbouw & 23 & 0 & 0 & 3 & 3 & 14 & 1 & 0 & 0 \\
\hline Techniek & 45 & 0 & 1 & 6 & 1 & 33 & 1 & 0 & 2 \\
\hline Economie & 22 & 0 & 0 & 1 & 2 & 17 & 1 & 0 & 1 \\
\hline Gezondheidszorg & 18 & - & - & - & - & - & - & - & - \\
\hline BBL niveau 3 & 25 & 0 & 0 & 3 & 1 & 23 & 3 & 0 & 1 \\
\hline Landbouw & 21 & - & - & - & - & - & - & - & - \\
\hline Techniek & 34 & 0 & 0 & 2 & 1 & 25 & 3 & 0 & 2 \\
\hline Economie & 31 & 0 & 1 & 4 & 1 & 20 & 4 & 0 & 1 \\
\hline Gezondheidszorg & 11 & - & - & - & - & - & - & - & - \\
\hline Gedrag en maatschappij & 18 & - & - & - & - & - & - & - & - \\
\hline BBL niveau 4 & 24 & 0 & 1 & 2 & 0 & 11 & 21 & 0 & 2 \\
\hline Landbouw & 7 & - & - & - & - & - & - & - & - \\
\hline Techniek & 34 & 0 & 0 & 2 & 0 & 13 & 15 & 0 & 3 \\
\hline Economie & 39 & 0 & 1 & 1 & 0 & 8 & 27 & 0 & 1 \\
\hline Gezondheidszorg & 14 & - & - & - & - & - & - & - & - \\
\hline Gedrag en maatschappij & 18 & - & - & - & - & - & - & - & - \\
\hline HBO & 36 & 0 & 0 & 0 & 0 & 0 & 7 & 21 & 8 \\
\hline Landbouw & 33 & 0 & 0 & 1 & 0 & 0 & 8 & 18 & 6 \\
\hline Onderwijs & 35 & 0 & 0 & 0 & 0 & 0 & 14 & 9 & 12 \\
\hline Techniek & 36 & 0 & 0 & 0 & 0 & 0 & 5 & 24 & 7 \\
\hline Economie & 43 & 0 & 0 & 0 & 0 & 0 & 4 & 30 & 8 \\
\hline Gezondheidszorg & 32 & 0 & 0 & 0 & 0 & 0 & 8 & 12 & 10 \\
\hline Gedrag en maatschappij & 29 & 0 & 0 & 0 & 0 & 0 & 8 & 13 & 8 \\
\hline Taal en cultuur & 23 & 0 & 0 & 0 & 0 & 0 & 11 & 8 & 3 \\
\hline Totaal & 66 & 1 & 7 & 18 & 4 & 5 & 20 & 11 & 2 \\
\hline
\end{tabular}


Tabel 12

Oordeel van schoolverlaters over de aansluiting van de afgesloten opleiding met de vervolgopleiding

\begin{tabular}{|c|c|c|c|c|}
\hline Opleidingssector & $\begin{array}{r}\text { goed } \\
\%\end{array}$ & $\begin{array}{r}\text { redelijk } \\
\%\end{array}$ & $\begin{array}{r}\text { matig } \\
\%\end{array}$ & $\begin{array}{r}\text { slecht } \\
\%\end{array}$ \\
\hline HAVO/VWO & 33 & 46 & 15 & 6 \\
\hline HAVO & 24 & 52 & 16 & 8 \\
\hline vwo & 45 & 38 & 13 & 4 \\
\hline VMBO & 35 & 42 & 16 & 7 \\
\hline \multicolumn{5}{|l|}{ Naar leerweg } \\
\hline Theoretisch & 36 & 40 & 16 & 7 \\
\hline Gemengd & 39 & 38 & 18 & 5 \\
\hline Kaderberoepsgericht & 34 & 41 & 18 & 6 \\
\hline Basisberoepsgericht & 35 & 44 & 15 & 6 \\
\hline
\end{tabular}

\begin{tabular}{|c|c|c|c|c|}
\hline \multicolumn{5}{|l|}{ Naar sector } \\
\hline Landbouw & 36 & 36 & 22 & 6 \\
\hline Techniek & 38 & 42 & 14 & 6 \\
\hline Economie & 32 & 49 & 12 & 7 \\
\hline Gezondheidszorg & 33 & 43 & 18 & 6 \\
\hline MBO & 37 & 38 & 16 & 9 \\
\hline BOL & 34 & 38 & 18 & 10 \\
\hline B0L niveau 1 & 55 & 39 & 3 & 3 \\
\hline B0L niveau 2 & 41 & 41 & 12 & 6 \\
\hline Landbouw & 20 & 48 & 20 & 11 \\
\hline Techniek & 38 & 43 & 10 & 10 \\
\hline Economie & 41 & 43 & 11 & 5 \\
\hline Gezondheidszorg & 45 & 37 & 14 & 3 \\
\hline BOL niveau 3 & 37 & 37 & 17 & 9 \\
\hline Landbouw & 37 & 30 & 20 & 13 \\
\hline Economie & 35 & 33 & 18 & 14 \\
\hline Gezondheidszorg & 35 & 37 & 21 & 7 \\
\hline Gedrag en maatschappij & 39 & 42 & 15 & 4 \\
\hline BOL niveau 4 & 27 & 36 & 24 & 13 \\
\hline Landbouw & 20 & 40 & 26 & 15 \\
\hline Techniek & 20 & 37 & 27 & 16 \\
\hline Economie & 30 & 37 & 21 & 12 \\
\hline Gezondheidszorg & 29 & 36 & 23 & 11 \\
\hline Gedrag en maatschappij & 29 & 35 & 25 & 11 \\
\hline
\end{tabular}




\section{Tabel 12}

Oordeel van schoolverlaters over de aansluiting van de afgesloten opleiding met de vervolgopleiding

\begin{tabular}{|c|c|c|c|c|}
\hline Opleidingssector & $\begin{array}{r}\text { goed } \\
\%\end{array}$ & $\begin{array}{r}\text { redelijk } \\
\%\end{array}$ & $\begin{array}{r}\text { matig } \\
\%\end{array}$ & $\begin{array}{r}\text { slecht } \\
\%\end{array}$ \\
\hline BBL & 48 & 36 & 10 & 6 \\
\hline BBL niveau 1 & 42 & 40 & 18 & 0 \\
\hline BBL niveau 2 & 57 & 34 & 4 & 5 \\
\hline BBL niveau 3 & 42 & 39 & 13 & 5 \\
\hline BBL niveau 4 & 35 & 36 & 17 & 12 \\
\hline Totaal & 35 & 42 & 16 & 7 \\
\hline
\end{tabular}


Tabel 13

Uitvallers en studiewisselaars

\begin{tabular}{|c|c|c|}
\hline & $\begin{array}{r}\text { Vervolgopleiding voortijdig } \\
\text { verlaten } \\
\%\end{array}$ & Studiewisselaar \\
\hline HAVO/VWO & 15 & 12 \\
\hline HAVO & 16 & 11 \\
\hline VWO & 14 & 13 \\
\hline VMBO & 10 & 8 \\
\hline \multicolumn{3}{|l|}{ Naar leerweg } \\
\hline Theoretisch & 11 & 9 \\
\hline Gemengd & 4 & 4 \\
\hline Kaderberoepsgericht & 13 & 11 \\
\hline Basisberoepsgericht & 10 & 7 \\
\hline
\end{tabular}

Naar sector
Landbouw
Techniek
Economie
Gezondheidszorg

MBO

BOL niveau 1

\begin{tabular}{lcc|}
\hline BOL niveau 2 & $\mathbf{6}$ & $\mathbf{2}$ \\
Landbouw & 7 & 0 \\
Techniek & 7 & 0 \\
Economie & 5 & 3 \\
Gezondheidszorg & 7 & 3 \\
\hline BoL niveau 3 & $\mathbf{6}$ & $\mathbf{2}$ \\
Landbouw & 9 & 1 \\
Economie & 7 & 3 \\
Gezondheidszorg & 5 & 1 \\
Gedrag en maatschappij & 6 & 1 \\
\hline BoL niveau 4 & & 4 \\
Landbouw & $\mathbf{1 1}$ & 4 \\
Techniek & 12 & 6 \\
Economie & 11 & 5 \\
Gezondheidszorg & 11 & 0 \\
Gedrag en maatschappij & 7 & 5
\end{tabular}


Statistische Bijlage

\section{Tabel 13}

Uitvallers en studiewisselaars

$\begin{array}{rrr}\text { Vervolgopleiding voortijdig } & \text { Studiewisselaar } \\ \text { verlaten } & \% & \%\end{array}$

BBL

6

1

BBL niveau 1

7

0

BBL niveau 2

5

0

BBL niveau 3

5

\section{BBL niveau 4}

11

2

HBO

Landbouw

Onderwiijs

Techniek

Economie

Gezondheidszorg

Gedrag en maatschappij

Taal en cultuur

$\begin{array}{ll}7 & 0 \\ 5 & 0 \\ 7 & 0 \\ 8 & 1 \\ 7 & 1 \\ 4 & 0 \\ 8 & 0 \\ 11 & 0\end{array}$

Totaal

11

7

Bron: ROA (SIS) 
Tabel 14

Werkloosheid

HAVO/VWO

HAVO

VWO

6

Naarleerweg

Theoretisch

Gemengd

Naar sector
Landbouw
Techniek
Economie
Gezondheidszorg

32

BOL

BOL niveau 1

BOL niveau 2

Landbouw

Techniek

Economie

Gezondheidszorg

BOL niveau 3

61

Landbouw

Techniek

Economie

Gezondheidszorg

Gedrag en maatschappij

BOL niveau 4

Landbouw

Techniek

Economie

Gezondheidszorg

Gedrag en maatschappij
67

69

43

73

65

52 


\section{Tabel 14}

Werkloosheid

BBL

\section{BBL niveau 1}

92

BBL niveau 2

Techniek

Economie

BBL niveau 3

Landbouw

Techniek

Economie

Gezondheidszorg

Gedrag en maatschappij

BBL niveau 4

0

\section{HBO}

Landbouw

Techniek

Economie

Gezondheidszorg

Bron: ROA (SIS)

\section{Toelichting}

Het werkloosheidspercentage heeft betrekking op de werkloze beroepsbevolking: schoolverlaters zonder werk (of met werk van minder dan 12 uur per week) die op zoek zijn naar betaald werk. Daarbij is tevens als voorwaarde gesteld dat de maatschappelijke positie niet scholier of student is. 
Tabel 15

Werkloosheid tot eerste baan

\begin{tabular}{|c|c|c|c|c|c|c|}
\hline Opleidingssector & $\begin{array}{r}0 \text { mnd. } \\
\%\end{array}$ & $\begin{array}{r}1-3 \text { mnd. } \\
\%\end{array}$ & $\begin{array}{r}4-6 \text { mnd. } \\
\%\end{array}$ & $\begin{array}{r}7-12 \text { mnd. } \\
\%\end{array}$ & $\begin{array}{r}>=13 \text { mnd. } \\
\%\end{array}$ & maanden \\
\hline VMBO & 91 & 5 & 3 & 2 & 0 & 0,4 \\
\hline \multicolumn{7}{|l|}{ Naar leerweg } \\
\hline Theoretisch & 92 & 1 & 5 & 3 & 0 & 0,5 \\
\hline Gemengd & 96 & 3 & 1 & 0 & 0 & 0,1 \\
\hline Kaderberoepsgericht & 94 & 3 & 0 & 4 & 0 & 0,4 \\
\hline Basisberoepsgericht & 89 & 6 & 3 & 1 & 0 & 0,5 \\
\hline
\end{tabular}

\begin{tabular}{|c|c|c|c|c|c|c|}
\hline \multicolumn{7}{|l|}{ Naar sector } \\
\hline Landbouw & 93 & 5 & 0 & 1 & 1 & 0,4 \\
\hline Techniek & 93 & 3 & 3 & 0 & 0 & 0,2 \\
\hline Economie & 94 & 3 & 1 & 3 & 0 & 0,4 \\
\hline Gezondheidszorg & 77 & 14 & 5 & 4 & 0 & 1,1 \\
\hline MBO & 90 & 6 & 3 & 1 & 0 & 0,4 \\
\hline BOL & 84 & 9 & 4 & 2 & 1 & 0,7 \\
\hline B0L niveau 1 & 88 & 6 & 2 & 0 & 4 & 0,8 \\
\hline B0L niveau 2 & 82 & 10 & 5 & 3 & 1 & 0,9 \\
\hline Landbouw & 65 & 27 & 7 & 1 & 0 & 1,1 \\
\hline Techniek & 84 & 8 & 5 & 2 & 0 & 0,7 \\
\hline Economie & 84 & 7 & 5 & 4 & 0 & 0,8 \\
\hline Gezondheidszorg & 81 & 10 & 4 & 2 & 3 & 1,3 \\
\hline B0L niveau 3 & 86 & 10 & 3 & 1 & 0 & 0,5 \\
\hline Landbouw & 87 & 11 & 2 & 1 & 0 & 0,3 \\
\hline Techniek & 86 & 11 & 3 & 0 & 0 & 0,4 \\
\hline Economie & 73 & 20 & 6 & 1 & 0 & 0,7 \\
\hline Gezondheidszorg & 90 & 6 & 2 & 1 & 1 & 0,5 \\
\hline Gedrag en maatschappij & 89 & 7 & 2 & 2 & 0 & 0,4 \\
\hline BOL niveau 4 & 85 & 8 & 5 & 2 & 0 & 0,6 \\
\hline Landbouw & 87 & 8 & 4 & 1 & 0 & 0,4 \\
\hline Techniek & 83 & 9 & 5 & 3 & 0 & 0,6 \\
\hline Economie & 78 & 12 & 6 & 3 & 0 & 0,9 \\
\hline Gezondheidszorg & 91 & 4 & 3 & 2 & 0 & 0,4 \\
\hline Gedrag en maatschappij & 87 & 6 & 5 & 1 & 1 & 0,6 \\
\hline
\end{tabular}


Tabel 15

Werkloosheid tot eerste baan

\begin{tabular}{|c|c|c|c|c|c|c|}
\hline Opleidingssector & $\begin{array}{r}0 \text { mnd. } \\
\%\end{array}$ & $\begin{array}{r}1-3 \text { mnd. } \\
\%\end{array}$ & $\begin{array}{r}4-6 \text { mnd. } \\
\%\end{array}$ & $\begin{array}{r}7-12 \text { mnd. } \\
\%\end{array}$ & $\begin{array}{r}>=13 \text { mnd. } \\
\%\end{array}$ & maanden \\
\hline BBL & 94 & 4 & 1 & 0 & 0 & 0,3 \\
\hline BBL niveau 1 & 100 & 0 & 0 & 0 & 0 & 0,0 \\
\hline BBL niveau 2 & 90 & 7 & 2 & 1 & 0 & 0,4 \\
\hline Landbouw & 92 & 4 & 0 & 3 & 0 & 0,5 \\
\hline Techniek & 87 & 10 & 3 & 0 & 0 & 0,4 \\
\hline Economie & 93 & 5 & 1 & 0 & 1 & 0,4 \\
\hline Gezondheidszorg & 94 & 0 & 4 & 1 & 0 & 0,3 \\
\hline BBL niveau 3 & 97 & 3 & 0 & 0 & 0 & 0,3 \\
\hline Landbouw & 98 & 2 & 0 & 0 & 0 & 0,0 \\
\hline Techniek & 96 & 3 & 1 & 1 & 0 & 0,2 \\
\hline Economie & 93 & 7 & 0 & 0 & 0 & 0,1 \\
\hline Gezondheidszorg & 100 & 0 & 0 & 0 & 0 & 0,0 \\
\hline Gedrag en maatschappij & 96 & 2 & 0 & 0 & 2 & 2,0 \\
\hline BBL niveau 4 & 97 & 2 & 0 & 0 & 0 & 0,1 \\
\hline Landbouw & - & - & - & - & - & - \\
\hline Techniek & 100 & 0 & 0 & 0 & 0 & 0,0 \\
\hline Economie & 91 & 8 & 0 & 0 & 0 & 0,2 \\
\hline Gezondheidszorg & 98 & 0 & 1 & 1 & 0 & 0,2 \\
\hline Gedrag en maatschappij & 99 & 1 & 0 & 0 & 0 & 0,0 \\
\hline HBO & 74 & 14 & 7 & 4 & 2 & 1,2 \\
\hline Landbouw & 71 & 16 & 9 & 3 & 1 & 1,2 \\
\hline Onderwijs & 86 & 9 & 3 & 1 & 1 & 0,7 \\
\hline Techniek & 73 & 15 & 7 & 4 & 2 & 1,2 \\
\hline Economie & 67 & 17 & 9 & 5 & 2 & 1,7 \\
\hline Gezondheidszorg & 83 & 10 & 4 & 2 & 1 & 0,7 \\
\hline Gedrag en maatschappij & 73 & 14 & 7 & 5 & 2 & 1,3 \\
\hline Taal en cultuur & 76 & 12 & 8 & 4 & 1 & 1,1 \\
\hline Totaal & 85 & 8 & 4 & 2 & 1 & 0,7 \\
\hline
\end{tabular}


Tabel 16

Werkzaam in klein-, midden-, grootbedrijf

\begin{tabular}{|c|c|c|c|}
\hline \multirow[t]{2}{*}{ Opleidingssector } & 1-9 personen & 10-99 personen & $>=100$ personen \\
\hline & $\%$ & $\%$ & $\%$ \\
\hline VMBO & 26 & 42 & 32 \\
\hline \multicolumn{4}{|l|}{ Naar leerweg } \\
\hline Theoretisch & 26 & 39 & 35 \\
\hline Gemengd & 11 & 59 & 30 \\
\hline Kaderberoepsgericht & 25 & 44 & 31 \\
\hline Basisberoepsgericht & 27 & 41 & 32 \\
\hline \multicolumn{4}{|l|}{ Naar sector } \\
\hline Landbouw & 40 & 40 & 20 \\
\hline Techniek & 23 & 50 & 27 \\
\hline Economie & 22 & 40 & 38 \\
\hline Gezondheidszorg & 27 & 24 & 48 \\
\hline MBO & 15 & 30 & 55 \\
\hline BOL & 18 & 30 & 52 \\
\hline BOL niveau 1 & 14 & 43 & 43 \\
\hline BOL niveau 2 & 21 & 28 & 51 \\
\hline Landbouw & 52 & 27 & 21 \\
\hline Techniek & 39 & 41 & 20 \\
\hline Economie & 9 & 25 & 66 \\
\hline Gezondheidszorg & 19 & 24 & 57 \\
\hline BOL niveau 3 & 18 & 34 & 48 \\
\hline Landbouw & 55 & 32 & 12 \\
\hline Techniek & 13 & 38 & 49 \\
\hline Economie & 14 & 43 & 42 \\
\hline Gezondheidszorg & 20 & 23 & 58 \\
\hline Gedrag en maatschappij & 10 & 38 & 52 \\
\hline BoL niveau 4 & 17 & 28 & 55 \\
\hline Landbouw & 50 & 31 & 18 \\
\hline Techniek & 17 & 33 & 50 \\
\hline Economie & 23 & 28 & 49 \\
\hline Gezondheidszorg & 14 & 26 & 60 \\
\hline Gedrag en maatschappij & 6 & 25 & 69 \\
\hline
\end{tabular}


Tabel 16

Werkzaam in klein-, midden-, grootbedrijf

\begin{tabular}{|c|c|c|c|}
\hline Opleidingssector & $1-9$ personen & 10-99 personen & $>=100$ personen \\
\hline & $\%$ & $\%$ & $\%$ \\
\hline BBL & 13 & 29 & 58 \\
\hline BBL niveau 1 & 12 & 15 & 73 \\
\hline BBL niveau 2 & 16 & 34 & 50 \\
\hline Landbouw & 33 & 18 & 49 \\
\hline Techniek & 18 & 43 & 39 \\
\hline Economie & 9 & 30 & 61 \\
\hline Gezondheidszorg & 13 & 18 & 69 \\
\hline BBL niveau 3 & 12 & 31 & 56 \\
\hline Landbouw & 21 & 46 & 34 \\
\hline Techniek & 17 & 41 & 42 \\
\hline Economie & 15 & 30 & 55 \\
\hline Gezondheidszorg & 6 & 14 & 80 \\
\hline Gedrag en maatschappij & 1 & 36 & 63 \\
\hline
\end{tabular}

\begin{tabular}{lrrr|}
\hline BBL niveau 4 & $\mathbf{6}$ & $\mathbf{2 2}$ & $\mathbf{7 2}$ \\
Landbouw & - & - & - \\
Techniek & 11 & 32 & 57 \\
Economie & 15 & 34 & 52 \\
Gezondheidszorg & 3 & 12 & 85 \\
Gedrag en maatschappij & 1 & 17 & 82
\end{tabular}

$\begin{array}{lrrr}\text { HBO } & \mathbf{1 7} & \mathbf{3 0} & \mathbf{5 4} \\ \text { Landbouw } & 24 & 31 & 46 \\ \text { Onderwijs } & 6 & 50 & 44 \\ \text { Techniek } & 15 & 34 & 51 \\ \text { Economie } & 12 & 28 & 59 \\ \text { Gezondheidszorg } & 27 & 20 & 53 \\ \text { Gedrag en maatschappij } & 6 & 20 & 74 \\ \text { Taal en cultuur } & 68 & 17 & 16 \\ & & & \mathbf{5 2} \\ \text { Totaal } & \mathbf{1 7} & \mathbf{3 1} & \end{array}$

- = te weinig waarnemingen

Bron: ROA (SIS) 
Tabel 17

Percentage werkende schoolverlaters met een flexibele aanstelling

Opleidingssector

HAVO/VWO

HAVO

VWO

VMBO

Naarleerweg

Theoretisch

Gemengd

Kaderberoepsgericht

Basisberoepsgericht

$\begin{array}{lr}\text { Naar sector } & 63 \\ \text { Landbouw } & 50 \\ \text { Techniek } & 72 \\ \text { Economie } & 66 \\ \text { Gezondheidszorg } & \end{array}$

MBO

BOL

BOL niveau 1

BOL niveau 2

Techniek

Economie

Gezondheidszorg

BOL niveau 3

Landbouw

Techniek

Economie 


\section{Tabel 17}

Percentage werkende schoolverlaters met een flexibele aanstelling

BBL niveau 1

BBL niveau 2

Economie

BBL niveau 3

\section{BBL niveau 4}

- = te weinig waarnemingen Bron: ROA (SIS)

\section{Toelichting}

Een flexibele aanstelling betreft een aanstelling als uitzendkracht, oproepkracht e.d. of een aanstelling in tijdelijke dienst. 
Tabel 18

Percentage werkende schoolverlaters met een deeltijdaanstelling en wekelijkse arbeidsduur

\begin{tabular}{|c|c|c|}
\hline Opleidingssector & $\begin{array}{r}\text { deeltijdaanstelling } \\
\%\end{array}$ & $\begin{array}{l}\text { wekelijkse } \\
\text { arbeidsduur uren }\end{array}$ \\
\hline HAVO/VWO & 67 & 24,5 \\
\hline HAVO & 66 & 24,7 \\
\hline VW0 & 73 & 23,6 \\
\hline VMBO & 66 & 30,5 \\
\hline \multicolumn{3}{|l|}{ Naar leerweg } \\
\hline Theoretisch & 75 & 26,1 \\
\hline Gemengd & 54 & 34,7 \\
\hline Kaderberoepsgericht & 72 & 30,0 \\
\hline Basisberoepsgericht & 62 & 31,4 \\
\hline
\end{tabular}

$\begin{array}{llr}\text { Naarsector } & 72 & 29,6 \\ \text { Landbouw } & 55 & 33,3 \\ \text { Techniek } & 68 & 31,9 \\ \text { Economie } & 77 & 26,7\end{array}$

MBO

$44 \quad 32,9$

BOL

52

BOL niveau 1

56

BOL niveau 2

49

Landbouw

32

33,2

Techniek

39

33,4

Economie

31

35,2

Gezondheidszorg

83

28,2

BOL niveau 3

63

30,2

Landbouw

32

Techniek

17

Economie

47

34,7

Gezondheidszorg

81

Gedrag en maatschappij

77

37,1

31,9

28,6

27,7

\section{BOL niveau 4}

48

Landbouw

Techniek

Economie

Gezondheidszorg

34,2

Gedrag en maatschappij

58

77

30,7

27,9 


\section{Tabel 18}

Percentage werkende schoolverlaters met een deeltijdaanstelling en wekelijkse arbeidsduur

Opleidingssector deeltijdaanstelling

\section{BBL niveau 2}

31

Landbouw

24

36,2

Techniek

16

37,9

Economie

Gezondheidszorg

89

\begin{tabular}{lrr}
\hline BBL niveau 3 & $\mathbf{4 1}$ & $\mathbf{3 3 , 5}$ \\
Landbouw & 13 & 37,6 \\
Techniek & 9 & 38,1 \\
Economie & 38 & 34,2 \\
Gezondheidszorg & 78 & 28,3 \\
Gedrag en maatschappij & 78 & 27,0
\end{tabular}

\section{BBL niveau 4}

46

Economie

Economie

- = te weinig waarnemingen Bron: ROA (SIS)

\section{Toelichting}

De arbeidsduur betreft zowel het aantal uren in de hoofdfunctie als het aantal uren in eventuele nevenfuncties (HBO). Een deeltijdaanstelling is een aanstelling met minder dan 33 arbeidsuren per week. 
Tabel 19

Aard van het dienstverband van werkende schoolverlaters

\begin{tabular}{|c|c|c|c|c|c|}
\hline Opleidingssector & $\begin{array}{c}\text { leer/werk- } \\
\text { overeenkomst }\end{array}$ & $\begin{array}{r}\text { uitzend-, } \\
\text { oproepkracht }\end{array}$ & $\begin{array}{l}\text { loondienst } \\
\text { werkgever }\end{array}$ & $\begin{array}{l}\text { bedrijf ouders/ } \\
\text { partner }\end{array}$ & eigen bedrijf/ free-lance \\
\hline & $\%$ & $\%$ & $\%$ & $\%$ & $\%$ \\
\hline HAVO/VWO & 14 & 7 & 76 & 2 & 0 \\
\hline HAVO & 18 & 7 & 73 & 3 & 0 \\
\hline VWo & 1 & 8 & 91 & 0 & 0 \\
\hline VMBO & 58 & 4 & 37 & 0 & 1 \\
\hline Naar leerweg & & & & & \\
\hline Theoretisch & 36 & 6 & 54 & 0 & 4 \\
\hline Gemengd & 55 & 19 & 13 & 2 & 11 \\
\hline Kaderberoepsgericht & 70 & 1 & 28 & 1 & 0 \\
\hline Basisberoepsgericht & 59 & 4 & 36 & 0 & 2 \\
\hline
\end{tabular}

\begin{tabular}{|c|c|c|c|c|c|}
\hline Naar sector & & & & & \\
\hline Landbouw & 56 & 4 & 39 & 1 & 1 \\
\hline Techniek & 67 & 2 & 31 & 0 & 0 \\
\hline Economie & 61 & 6 & 31 & 2 & 0 \\
\hline Gezondheidszorg & 53 & 4 & 41 & 0 & 2 \\
\hline MBO & 16 & 5 & 78 & 0 & 1 \\
\hline BOL & 11 & 8 & 79 & 0 & 2 \\
\hline BoL niveau 1 & 35 & 10 & 51 & 0 & 5 \\
\hline B0L niveau 2 & 25 & 7 & 66 & 0 & 1 \\
\hline Landbouw & 29 & 0 & 71 & 0 & 0 \\
\hline Techniek & 14 & 18 & 67 & 0 & 0 \\
\hline Economie & 21 & 6 & 72 & 0 & 1 \\
\hline Gezondheidszorg & 39 & 2 & 57 & 0 & 2 \\
\hline B0L niveau 3 & 8 & 9 & 81 & 0 & 2 \\
\hline Landbouw & 11 & 8 & 77 & 0 & 5 \\
\hline Techniek & 15 & 7 & 78 & 0 & 0 \\
\hline Economie & 7 & 12 & 82 & 0 & 0 \\
\hline Gezondheidszorg & 8 & 6 & 83 & 1 & 2 \\
\hline Gedrag en maatschappij & 6 & 11 & 81 & 0 & 2 \\
\hline BOL niveau 4 & 6 & 7 & 85 & 0 & 2 \\
\hline Landbouw & 5 & 7 & 76 & 2 & 9 \\
\hline Techniek & 5 & 8 & 85 & 0 & 2 \\
\hline Economie & 7 & 10 & 81 & 0 & 1 \\
\hline Gezondheidszorg & 6 & 2 & 91 & 0 & 0 \\
\hline Gedrag en maatschappij & 5 & 8 & 85 & 0 & 2 \\
\hline
\end{tabular}


Tabel 19

Aard van het dienstverband van werkende schoolverlaters

\begin{tabular}{|c|c|c|c|c|c|}
\hline Opleidingssector & $\begin{array}{r}\text { leer/werk- } \\
\text { overeenkomst }\end{array}$ & $\begin{array}{r}\text { uitzend-, } \\
\text { oproepkracht }\end{array}$ & $\begin{array}{l}\text { loondienst } \\
\text { werkgever }\end{array}$ & $\begin{array}{l}\text { bedrijf ouders/ } \\
\text { partner }\end{array}$ & eigen bedrijf/ free-lance \\
\hline & $\%$ & $\%$ & $\%$ & $\%$ & $\%$ \\
\hline BBL & 19 & 2 & 78 & 0 & 1 \\
\hline BBL niveau 1 & 17 & 0 & 83 & 0 & 0 \\
\hline BBL niveau 2 & 20 & 4 & 75 & 0 & 1 \\
\hline Landbouw & 16 & 0 & 79 & 3 & 2 \\
\hline Techniek & 26 & 6 & 67 & 0 & 0 \\
\hline Economie & 13 & 2 & 84 & 0 & 0 \\
\hline Gezondheidszorg & 10 & 1 & 83 & 0 & 5 \\
\hline BBL niveau 3 & 19 & 2 & 78 & 0 & 1 \\
\hline Landbouw & 14 & 8 & 67 & 7 & 4 \\
\hline Techniek & 16 & 2 & 80 & 0 & 1 \\
\hline Economie & 14 & 4 & 82 & 0 & 0 \\
\hline Gezondheidszorg & 25 & 0 & 75 & 0 & 0 \\
\hline Gedrag en maatschappij & 22 & 0 & 78 & 0 & 0 \\
\hline BBL niveau 4 & 16 & 0 & 83 & 0 & 1 \\
\hline Landbouw & - & - & - & - & - \\
\hline Techniek & 3 & 0 & 96 & 0 & 1 \\
\hline Economie & 14 & 0 & 84 & 0 & 2 \\
\hline Gezondheidszorg & 22 & 0 & 78 & 0 & 0 \\
\hline Gedrag en maatschappij & 23 & 1 & 76 & 0 & 0 \\
\hline HBO & 0 & 7 & 84 & 0 & 8 \\
\hline Landbouw & 0 & 6 & 80 & 5 & 8 \\
\hline Onderwijs & 0 & 13 & 86 & 0 & 1 \\
\hline Techniek & 0 & 4 & 90 & 1 & 5 \\
\hline Economie & 0 & 9 & 86 & 0 & 4 \\
\hline Gezondheidszorg & 0 & 3 & 89 & 0 & 7 \\
\hline Gedrag en maatschappij & 0 & 8 & 90 & 0 & 1 \\
\hline Taal en cultuur & 0 & 3 & 35 & 0 & 62 \\
\hline Totaal & 17 & 5 & 74 & 0 & 3 \\
\hline
\end{tabular}

- = te weinig waarnemingen Bron: ROA (SIS) 
Tabel 20

Vereist opleidingsniveau voor de huidige functie volgens de werkgever

$\begin{array}{lccr}\text { Opleidingssector } & \begin{array}{r}\text { lager } \\ \%\end{array} & \begin{array}{r}\text { zelfde } \\ \%\end{array} & \text { hoger } \\ & & & 67 \\ \text { VMBO } & \mathbf{8} & \mathbf{2 5} & 54 \\ \text { Naarleerweg } & & 33 & 69 \\ \text { Theoretisch } & 13 & 24 & 60 \\ \text { Gemengd } & 6 & 31 & 72 \\ \text { Kaderberoepsgericht } & 9 & 22 & \end{array}$

\begin{tabular}{|c|c|c|c|}
\hline \multicolumn{4}{|l|}{ Naar sector } \\
\hline Landbouw & 7 & 23 & 69 \\
\hline Techniek & 5 & 26 & 69 \\
\hline Economie & 11 & 15 & 74 \\
\hline Gezondheidszorg & 10 & 23 & 67 \\
\hline MBO & 25 & 65 & 10 \\
\hline BOL & 18 & 72 & 9 \\
\hline BOL niveau 1 & 21 & 70 & 9 \\
\hline BOL niveau 2 & 26 & 47 & 27 \\
\hline Landbouw & 17 & 74 & 8 \\
\hline Techniek & 13 & 53 & 33 \\
\hline Economie & 38 & 38 & 24 \\
\hline Gezondheidszorg & 19 & 51 & 30 \\
\hline BOL niveau 3 & 22 & 75 & 2 \\
\hline Landbouw & 27 & 73 & \\
\hline Techniek & 47 & 49 & 4 \\
\hline Economie & 32 & 60 & 8 \\
\hline Gezondheidszorg & 24 & 76 & \\
\hline Gedrag en maatschappij & 7 & 93 & 1 \\
\hline B0L niveau 4 & 13 & 81 & 6 \\
\hline Landbouw & 24 & 76 & \\
\hline Techniek & 18 & 77 & 5 \\
\hline Economie & 19 & 69 & 12 \\
\hline Gezondheidszorg & 6 & 93 & 2 \\
\hline Gedrag en maatschappij & 8 & 87 & 5 \\
\hline
\end{tabular}


Tabel 20

Vereist opleidingsniveau voor de huidige functie volgens de werkgever

\begin{tabular}{|c|c|c|c|}
\hline \multirow[t]{2}{*}{ Opleidingssector } & lager & zelfde & hoger \\
\hline & $\%$ & $\%$ & $\%$ \\
\hline BBL & 30 & 59 & 10 \\
\hline BBL niveau 1 & 56 & 36 & 8 \\
\hline BBL niveau 2 & 31 & 47 & 22 \\
\hline Landbouw & 40 & 42 & 17 \\
\hline Techniek & 30 & 48 & 21 \\
\hline Economie & 34 & 45 & 22 \\
\hline Gezondheidszorg & 25 & 50 & \\
\hline
\end{tabular}

\begin{tabular}{|c|c|c|}
\hline BBL niveau 3 & 32 & 67 \\
\hline Landbouw & 39 & 61 \\
\hline Techniek & 45 & 55 \\
\hline Economie & 41 & 57 \\
\hline Gezondheidszorg & 16 & 83 \\
\hline Gedrag en maatschappij & 7 & 93 \\
\hline
\end{tabular}

$\begin{array}{lccc}\text { BBL niveau 4 } & \mathbf{1 5} & \mathbf{8 0} & \mathbf{4} \\ \text { Landbouw } & - & - & - \\ \text { Techniek } & 26 & 71 & 3 \\ \text { Economie } & 27 & 70 & 3 \\ \text { Gezondheidszorg } & 6 & 89 & 4 \\ \text { Gedrag en maatschappij } & 10 & 84 & 7\end{array}$

$\begin{array}{lccc}\text { HBO } & \mathbf{2 1} & \mathbf{7 8} & \mathbf{2} \\ \text { Landbouw } & 25 & 75 & 1 \\ \text { Onderwijs } & 6 & 93 & 1 \\ \text { Techniek } & 15 & 84 & 1 \\ \text { Economie } & 23 & 74 & 3 \\ \text { Gezondheidszorg } & 18 & 81 & 1 \\ \text { Gedrag en maatschappij } & 38 & 62 & 0 \\ \text { Taal en cultuur } & 23 & 72 & 5 \\ & & & \mathbf{1 6}\end{array}$

- te weinig waarnemingen Bron: ROA (SIS)

\section{Toelichting}

Vraag in de enquête:

Welk opleidingsniveau werd door uw werkgever voor deze functie minimaal vereist? 


\section{Tabel 21}

Vereiste opleidingsrichting voor de huidige functie volgens de werkgever

Opleidingssector eigen/verwan
richting
VMBO
Naarleerweg
Theoretisch
Gemengd
Kaderberoepsgericht
Basisberoepsgericht

$\begin{array}{rr}\text { verwante } & \text { geen/andere } \\ \text { richting } & \text { richting } \\ \% & \%\end{array}$

$\begin{array}{lll}\text { Naar sector } & & 28 \\ \text { Landbouw } & 72 & 25 \\ \text { Techniek } & 75 & 38 \\ \text { Economie } & 62 & 50 \\ \text { Gezondheidszorg } & 50 & 50\end{array}$

MBO

72

BOL

73

BOL niveau 2

Economie

BOL niveau 3

Economie

\section{BOL niveau 4}




\section{Tabel 21}

Vereiste opleidingsrichting voor de huidige functie volgens de werkgever

$\begin{array}{rrr}\text { Opleidingssector } & \text { eigen/verwante } & \text { geen/andere } \\ & \text { richting } & \text { richting } \\ & \% & \%\end{array}$

BBL

\section{BBL niveau 1}

51

\section{BBL niveau 2}

64

Landbouw

Techniek

Economie

Gezondheidszorg

54

79

$\begin{array}{lll}\text { BBL niveau 3 } & \mathbf{7 9} & \mathbf{2 1} \\ \text { Landbouw } & 84 & 16 \\ \text { Techniek } & 79 & 21 \\ \text { Economie } & 62 & 38 \\ \text { Gezondheidszorg } & 88 & 12 \\ \text { Gedrag en maatschappij } & 87 & 13\end{array}$

\section{BBL niveau 4}

Economie

- te weinig waarnemingen Bron: ROA (SIS)

\section{Toelichting}

Vraag in de enquête:

Welke opleidingsrichting werd door uw werkgever voor deze functie vereist? 
Tabel 22

Oordeel van de werkende schoolverlaters over de aansluiting tussen de afgesloten opleiding en de huidige functie

\begin{tabular}{|c|c|c|c|c|}
\hline \multirow[t]{2}{*}{ Opleidingssector } & goed & voldoende & matig & slecht \\
\hline & $\%$ & $\%$ & $\%$ & $\%$ \\
\hline VMBO & 27 & 43 & 20 & 11 \\
\hline \multicolumn{5}{|l|}{ Naar leerweg } \\
\hline Theoretisch & 17 & 40 & 34 & 9 \\
\hline Gemengd & 18 & 43 & 37 & 2 \\
\hline Kaderberoepsgericht & 30 & 46 & 18 & 7 \\
\hline Basisberoepsgericht & 28 & 41 & 18 & 13 \\
\hline \multicolumn{5}{|l|}{ Naar sector } \\
\hline Landbouw & 29 & 47 & 16 & 9 \\
\hline Techniek & 29 & 40 & 16 & 15 \\
\hline Economie & 22 & 45 & 27 & 5 \\
\hline Gezondheidszorg & 33 & 48 & 10 & 9 \\
\hline MBO & 34 & 46 & 14 & 6 \\
\hline BOL & 29 & 46 & 17 & 8 \\
\hline BoL niveau 1 & 47 & 35 & 12 & 6 \\
\hline BOL niveau 2 & 34 & 42 & 14 & 10 \\
\hline Landbouw & 29 & 45 & 12 & 14 \\
\hline Techniek & 35 & 39 & 14 & 11 \\
\hline Economie & 31 & 42 & 16 & 12 \\
\hline Gezondheidszorg & 40 & 45 & 10 & 5 \\
\hline BOL niveau 3 & 30 & 49 & 15 & 7 \\
\hline Landbouw & 16 & 55 & 20 & 8 \\
\hline Techniek & 4 & 58 & 13 & 24 \\
\hline Economie & 19 & 44 & 25 & 11 \\
\hline Gezondheidszorg & 38 & 49 & 9 & 5 \\
\hline Gedrag en maatschappij & 39 & 46 & 13 & 2 \\
\hline BOL niveau 4 & 26 & 48 & 19 & 7 \\
\hline Landbouw & 25 & 51 & 14 & 10 \\
\hline Techniek & 26 & 45 & 20 & 10 \\
\hline Economie & 23 & 54 & 15 & 8 \\
\hline Gezondheidszorg & 29 & 44 & 22 & 5 \\
\hline Gedrag en maatschappij & 27 & 47 & 22 & 4 \\
\hline
\end{tabular}




\section{Tabel 22}

Oordeel van de werkende schoolverlaters over de aansluiting tussen de afgesloten opleiding en de huidige functie

\begin{tabular}{|c|c|c|c|c|}
\hline Opleidingssector & goed & voldoende & matig & slecht \\
\hline & $\%$ & $\%$ & $\%$ & $\%$ \\
\hline BBL & 37 & 46 & 13 & 5 \\
\hline BBL niveau 1 & 44 & 37 & 16 & 3 \\
\hline BBL niveau 2 & 34 & 45 & 14 & 7 \\
\hline Landbouw & 30 & 53 & 13 & 4 \\
\hline Techniek & 28 & 46 & 16 & 10 \\
\hline Economie & 39 & 42 & 16 & 3 \\
\hline Gezondheidszorg & 50 & 42 & 6 & 3 \\
\hline BBL niveau 3 & 38 & 48 & 10 & 3 \\
\hline Landbouw & 29 & 36 & 30 & 5 \\
\hline Techniek & 32 & 56 & 7 & 4 \\
\hline Economie & 39 & 36 & 20 & 6 \\
\hline Gezondheidszorg & 47 & 49 & 4 & \\
\hline Gedrag en maatschappij & 43 & 48 & 8 & 1 \\
\hline BBL niveau 4 & 37 & 47 & 13 & 3 \\
\hline Landbouw & - & - & - & - \\
\hline Techniek & 39 & 38 & 17 & 6 \\
\hline Economie & 30 & 43 & 20 & 6 \\
\hline Gezondheidszorg & 33 & 54 & 10 & 3 \\
\hline Gedrag en maatschappij & 44 & 46 & 9 & \\
\hline HBO & 32 & 42 & 18 & 7 \\
\hline Landbouw & 37 & 38 & 16 & 9 \\
\hline Onderwijs & 44 & 43 & 11 & 3 \\
\hline Techniek & 31 & 46 & 17 & 5 \\
\hline Economie & 26 & 43 & 22 & 10 \\
\hline Gezondheidszorg & 40 & 41 & 15 & 4 \\
\hline Gedrag en maatschappij & 27 & 44 & 23 & 7 \\
\hline Taal en cultuur & 40 & 33 & 15 & 12 \\
\hline Totaal & 32 & 44 & 17 & 7 \\
\hline
\end{tabular}

- = te weinig waarnemingen

Bron: ROA (SIS)

\section{Toelichting}

Vraag in de enquête:

Hoe vindt $u$ de aansluiting tussen uw [...] opleiding en uw huidige functie? 
Tabel 23

Beloning van werkende schoolverlaters

Opleidingssector

gemiddeld

bruto maandloon

\section{$€$}

638

633

663

623

4,68

Naarleerweg

Theoretisch

Gemengd

Kaderberoepsgericht

Basisberoepsgericht

Naar sector

Landbouw

Techniek

Economie

Gezondheidszorg

MBO

1.501

10,69

BOL

1.317

9,72

BOL niveau 1

884

BOL niveau 2

Landbouw

1.113

1.418

1.259

1.103

979

Techniek

979

Gezondheidszorg

BoL niveau 3

1.263

Landbouw

1.132

Techniek

1.737

10,57

Economie

1.151

Gezondheidszorg

1.235

10,09

Gedrag en maatschappij

1.243

10,59

\section{BOL niveau 4}

1.454

Landbouw

1.308

Techniek

1.605

Economie

1.368

Gezondheidszorg

1.550

Gedrag en maatschappij
9,77

7,57

8,44

10,64

9,45

10,94

9,25

11,63 


\section{Tabel 23}

Beloning van werkende schoolverlaters

$\begin{array}{rr}\text { gemiddeld } \\ \text { Opleidingssector } & \text { gemiddeld } \\ \text { bruto uurloon } \\ €\end{array}$

BBL

1.636

11,40

BBL niveau 1

1.257

BBL niveau 2

1.533

10,30

Landbouw

1.477

Techniek

1.632

Economie

1.507

Gezondheidszorg

1.260

\section{BBL niveau 3}

1.682

11,95

Landbouw

1.780

10,79

Techniek

2.021

13,03

Economie

1.391

Gezondheidszorg

1.533

12,65

Gedrag en maatschappij

1.300

11,43

\section{BBL niveau 4}

1.926

13,70

Landbouw

Techniek

2.344

14,48

Economie

1.575

Gezondheidszorg

1.872

Gedrag en maatschappij

1.868

\section{HBO}

2.030

13,53

Landbouw

2.246

13,72

Onderwijs

1.963

13,89

Techniek

2.352

Economie

2.119

13,33

Gezondheidszorg

2.025

\section{Totaal}

- = te weinig waarnemingen

Bron: ROA (SIS)

\section{Toelichting}

Dit betreft het bruto inkomen in de hoofdfunctie. Dit is inclusief toeslagen maar exclusief inkomen uit overwerk. Er is hier niet gecorrigeerd voor verschillen in leeftijd van de schoolverlaters. 


\section{Tabel 24}

Tevredenheid met huidige functie

Opleidingssector

VMBO

Naar leerweg

Theoretisch

Gemengd

Kaderberoepsgericht

Basisberoepsgericht

Naar sector

Landbouw

Techniek

Economie

Gezondheidszorg

BOL

BOL niveau 1

BOL niveau 2

Landbouw

Techniek

Economie

BOL niveau 3

Techniek

Economie

Gedrag en maatschappij

BOL niveau 4

Economie 


\section{Tabel 24}

Tevredenheid met huidige functie

Opleidingssector $\%$

BBL

BBL niveau 1

BBL niveau 2

Economie

BBL niveau 3

Landbouw

Techniek

Economie

BBL niveau 4

Economie

- = te weinig waarnemingen

Bron: ROA (SIS)

\section{Toelichting}

Vraag in de enquête:

Hoe tevreden bent u met uw huidige functie ( 1 'zeer ontevreden' tot en met 5 'zeer tevreden'. Vermeld is het percentage van antwoordcategorie 4 en 5. 


\section{Tabel 25}

Percentage werkende schoolverlaters waarvan huidige functie goede carrièreperspectieven biedt

Opleidingssector

VMBO

Naarleerweg

Theoretisch

Gemengd

Kaderberoepsgericht

Basisberoepsgericht

Naar sector

Landbouw

Techniek

Economie

Gezondheidszorg

BOL

BOL niveau 1

BOL niveau 2

Landbouw

Techniek

Economie

BOL niveau 3

Economie

Gezondheidszorg

Gedrag en maatschappij

BOL niveau 4

Economie 


\section{Tabel 25}

Percentage werkende schoolverlaters waarvan huidige functie goede carrièreperspectieven biedt

Opleidingssector

BBL

BBL niveau 1

BBL niveau 2

Techniek

Economie

Gezondheidszorg

BBL niveau 3

Landbouw

Techniek

Economie

\section{BBL niveau 4}

Techniek

Economie

- = te weinig waarnemingen

Bron: ROA (SIS)

\section{Toelichting}

Vraag in de enquête:

Biedt uw functie goede carrièremogelijkheden? ( 1 'nauwelijks' tot en met 5 'heel veel'). Vermeld is het percentage van antwoordcategorie 4 en 5. 
Tabel 26

Benutting van kennis en vaardigheden en kennis en vaardigheden schieten tekort volgens oordeel werkende schoolverlaters

$\begin{array}{lrr}\text { Opleidingssector } & \text { Benutting kennis en vaardigheden } & \text { Kennis en vaardigheden schieten tekort } \\ & \% & \% \\ \text { VMBO } & 56 & \mathbf{8} \\ \text { Naarleerweg } & 61 & 4 \\ \text { Theoretisch } & 43 & 14 \\ \text { Gemengd } & 60 & 10 \\ \text { Kaderberoepsgericht } & 54 & 9 \\ \text { Basisberoepsgericht } & & \\ & & 15 \\ \text { Naar sector } & 58 & 5 \\ \text { Landbouw } & 58 & 17 \\ \text { Techniek } & 42 & 8 \\ \text { Economie } & 59 & \\ \text { Gezondheidszorg } & & \end{array}$

MBO

67

BOL

67

13

BOL niveau 1

54

13

BOL niveau 2

$65 \quad 13$

Landbouw

58

Techniek

70

Economie

57

Gezondheidszorg

76

BOL niveau 3

67

Landbouw

Techniek

58

Economie

49

Gezondheidszorg

79

Gedrag en maatschappij

78

BOL niveau 4

Landbouw

Techniek

57

Economie

59

Gezondheidszorg

81

Gedrag en maatschappij

71 


\section{Tabel 26}

Benutting van kennis en vaardigheden en kennis en vaardigheden schieten tekort volgens oordeel werkende schoolverlaters

$\begin{array}{rrr}\text { Opleidingssector } & \text { Benutting kennis en vaardigheden } & \text { Kennis en vaardigheden schieten tekort } \\ \% & \%\end{array}$

BBL

BBL niveau 1

\section{3}

\section{2}

\section{BBL niveau 2}

Landbouw

Techniek

Economie

Gezondheidszorg

$\begin{array}{rr}62 & 10 \\ 44 & 6 \\ 60 & 12 \\ 58 & 9 \\ 84 & 8\end{array}$

6

$\begin{array}{lrr}\text { BBL niveau 3 } & \mathbf{7 1} & \mathbf{1 0} \\ \text { Landbouw } & 47 & 4 \\ \text { Techniek } & 68 & 11 \\ \text { Economie } & 64 & 8 \\ \text { Gezondheidszorg } & 82 & 9 \\ \text { Gedrag en maatschappij } & 76 & 10\end{array}$

BBL niveau 4

75

10

Landbouw

Techniek

62

57

86

85

Gedrag en maatschappij

HBO

$63 \quad 7$

Landbouw

62

Onderwijs

Techniek

83

64

52

Economie

77

Gedrag en maatschappij

60

64

10

\section{0}

- te weinig waarnemingen Bron: ROA (SIS)

\section{Toelichting}

Vragen in de enquête:

In welke mate worden in uw huidige functie uw kennis en vaardigheden benut ( 1 'helemaal niet' tot en met 5 'in sterke mate'). Vermeld is het percentage van antwoordcategorie 4 en 5.

In welke mate schieten uw kennis en vaardigheden tekort voor uw huidige functie ( 1 'helemaal niet' tot en met 5 'in sterke mate')? Vermeld is het percentage van antwoordcategorie 4 en 5. 
Tabel 27

Percentage werkende schoolverlaters dat op zoek is naar een andere baan

Opleidingssector

HAVO/VWO

HAVO

vW0

VMBO

Naarleerweg

Theoretisch

Gemengd

Kaderberoepsgericht

Kasiser

Basisberoepsgericht

Naar sector

Landbouw

Techniek

Economie

Gezondheidszorg

BOL

BOL niveau 1

BOL niveau 2

Landbouw

Techniek

Economie

Gezondheidszorg

BOL niveau 3

Techniek

Economie

BOL niveau 4

Landbouw

Techniek

Economie 
Statistische Bijlage

Tabel 27

Percentage werkende schoolverlaters dat op zoek is naar een andere baan

Opleidingssector $\%$

BBL

BBL niveau 1

BBL niveau 2

Techniek

Economie

Gezondheidszorg

BBL niveau 3

Landbouw

Techniek

Economie

BBL niveau 4

Landbouw

Techniek

Economie

Gezondheidszor

Gedrag en maatschappij

Landbouw

Economie

- = te weinig waarnemingen

Bron: ROA (SIS) 
Tabel 28

Opleiding achteraf opnieuw kiezen

\begin{tabular}{|c|c|c|}
\hline & $\begin{array}{r}\text { zelfde } \\
\text { opleiding }\end{array}$ & $\begin{array}{r}\text { andere } \\
\text { opleiding }\end{array}$ \\
\hline Opleidingssector & $\%$ & $\%$ \\
\hline AVO & 95 & 5 \\
\hline HAVO & 94 & 6 \\
\hline vw0 & 97 & 3 \\
\hline VMBO & 84 & 16 \\
\hline \multicolumn{3}{|l|}{ Naar leerweg } \\
\hline Theoretisch & 89 & 11 \\
\hline Gemengd & 88 & 12 \\
\hline Kaderberoepsgericht & 81 & 19 \\
\hline Basisberoepsgericht & 80 & 20 \\
\hline
\end{tabular}

Naar sector

Landbouw $\quad 83 \quad 17$

$\begin{array}{lll}\text { Techniek } & 82 & 18\end{array}$

$\begin{array}{lll}\text { Economie } & 76 & 24\end{array}$

$\begin{array}{lll}\text { Gezondheidszorg } & 82 & 18\end{array}$

MBO

80

20

BOL

78

22

BOL niveau 1

72

BOL niveau 2

75

25

Landbouw

72

28

Techniek

64

Economie

76

Gezondheidszorg

81

BOL niveau 3

$\begin{array}{ll}79 & 21\end{array}$

Landbouw

73

21

Techniek

Economie

92

Gezondheidszorg

Gedrag en maatschappij

BOL niveau 4

79

21

Landbouw

75

Techniek

79

21

Economie

Gezondheidszorg

Gedrag en maatschappij 


\section{Tabel 28}

Opleiding achteraf opnieuw kiezen

$\begin{array}{rrr} & \text { zelfde } & \text { andere } \\ \text { opleiding } \\ \text { Opleidingssector } & \text { opleiding } & \%\end{array}$

BBL

BBL niveau 1

\section{BBL niveau 2}

81

Landbouw

82

Techniek

81

Economie

Gezondheidszorg

78

\begin{tabular}{lrr}
\hline BBL niveau 3 & $\mathbf{8 5}$ & $\mathbf{1 5}$ \\
Landbouw & 90 & 10 \\
Techniek & 84 & 16 \\
Economie & 78 & 22 \\
Gezondheidszorg & 95 & 5 \\
Gedrag en maatschappij & 77 & 23
\end{tabular}

\section{BBL niveau 4}

$83 \quad 17$

Landbouw

93

Techniek

87

Economie

69

Gezondheidszorg

78

Gedrag en maatschappij

94

Landbouw

78

Onderwijs

Techniek

87

Economie

84

Gezondheidszorg

72

Gedrag en maatschappij

85

75

Taal en cultuur

87

Bron: ROA (SIS) 
